\author{
UNIVERSIDADE DE SÃO PAULO \\ FACULDADE DE FILOSOFIA, LETRAS E CIÊNCIAS HUMANAS \\ DEPARTAMENTO DE HISTÓRIA \\ PROGRAMA DE PÓS-GRADUAÇÃO EM HISTÓRIA ECONÔMICA
}

Silvia Carvalho Ricardo

\title{
EXPOENTES MERCANTIS E DINÂMICA DE NEGÓCIOS: A FAMÍLIA DIAS DE MILÃO \\ (1580-1624)
}

São Paulo

2014 


\author{
UNIVERSIDADE DE SÃO PAULO \\ FACULDADE DE FILOSOFIA, LETRAS E CIÊNCIAS HUMANAS \\ DEPARTAMENTO DE HISTÓRIA \\ PROGRAMA DE PÓS-GRADUAÇÃO EM HISTÓRIA ECONÔMICA
}

\title{
EXPOENTES MERCANTIS E DINÂMICA DE NEGÓCIOS: A FAMÍLIA DIAS DE MILÃO \\ (1580-1624)
}

Silvia Carvalho Ricardo

Tese apresentada ao Programa de PósGraduação em História Econômica do Departamento de História da Faculdade de Filosofia, Letras e Ciências Humanas da Universidade de São Paulo, para a obtenção do título de Doutor em História.

Orientadora: Profa Dra Vera Lucia Amaral Ferlini

São Paulo

2014

Versão corrigida 


\section{Agradecimentos}

Em primeiro lugar, um agradecimento especial à Professora Dr ${ }^{\mathrm{a}}$ Vera Lucia Amaral Ferlini, minha orientadora, por ter me recebido como sua orientanda, no mestrado e no doutorado e ter acreditado na possibilidade de concretizarmos este trabalho.

Agradeço à Cátedra Jaime Cortesão da Faculdade de Filosofia, Letras e Ciências Humanas da Universidade de São Paulo, em convênio com o Instituto Camões, que me concedeu bolsa para pesquisa em Portugal durante os meses de fevereiro a abril de 2011. A pesquisa junto às fontes portuguesas foi determinante para as bases documentais desta tese.

Meus agradecimentos pela forma amável que fui recebida em Lisboa pelo Prof. Dr. António Augusto Marques de Almeida e pela Prof ${ }^{a}$ Dra Florbela Veiga Frade que me mostraram alguns caminhos que a pesquisa poderia seguir.

Ao Prof. Dr. Ângelo Adriano Faria de Assis que generosamente facilitou - acesso aos documentos, cedendo microfilmes e cópias de fontes documentais.

À Prof ${ }^{a}$ Ana Vukovar por sua disponibilidade para a troca de ideias e de informações, o que muito enriqueceu este trabalho.

Ao Fernando Vedovate e à Magna Reimberg, amigos de todas as horas, que acompanharam os momentos de dificuldades e alegrias encontrados no decorrer deste trabalho. 
E aos meus pais, Hélio e Vera, que, cada um a seu modo, mostraramme a importância do saber, da ética e da integridade em seu sentido mais amplo.

Ao Gabriel, por tudo o que passou e ser quem é.

A Laura, Tica, Zizi e Henrique, por preencherem tão bem minha vida. 
Sumário

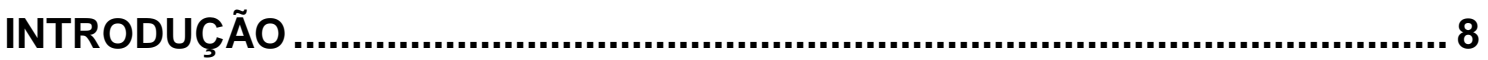

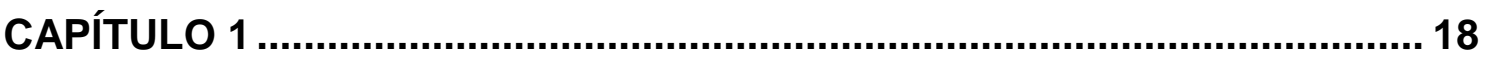

MERCADORES, BANQUEIROS, FINANCISTAS NO IMPÉRIO PORTUGUÊS 18

1.2. OS JUDEUS E CRISTÃOS-NOVOS EM PORTUGAL ............................. 39

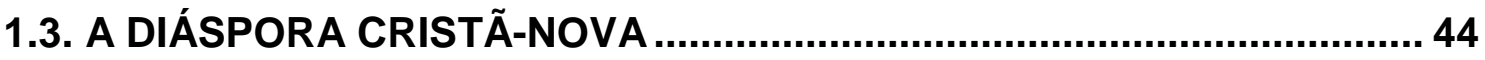

1.4. A ASCENSÃO DOS CRISTÃOS-NOVOS NO COMÉRCIO E NAS

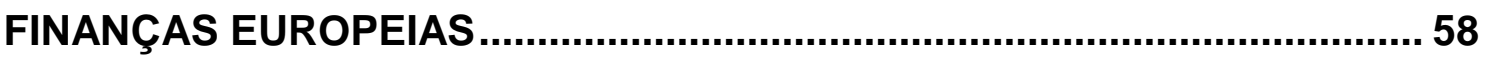

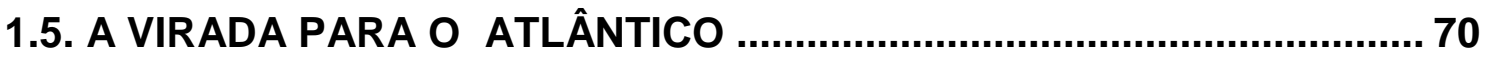

1.6 A IMPLANTAÇÃO DA EMPRESA COLONIAL....................................... 73

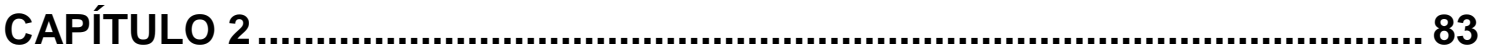

A FAMÍLIA E OS NEGÓCIOS DOS DIAS DE MILÃO.................................... 83

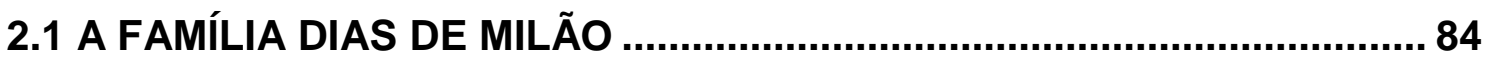

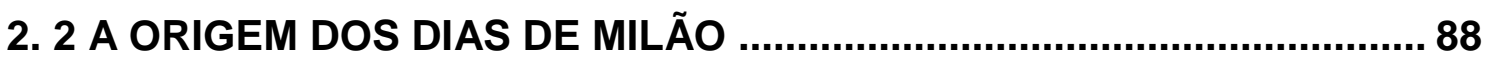

2.3 A MOBILIDADE DAS REDES E OS PERDÕES GERAIS........................100

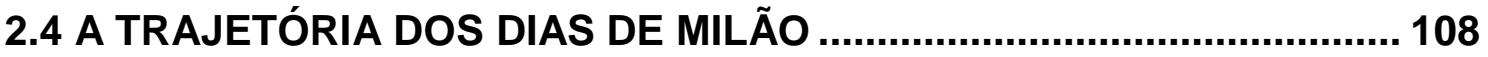


2.5. A REDE DOS DIAS DE MILÃO: DE GOA AO MÉXICO

2.6. A REDE DE COMÉRCIO DOS MILÃO NO AÇÚCAR BRASILEIRO ..... 127

CAPÍTULO 3

A AÇÃO MERCANTIL DOS MILÃO EM AMSTERDÃ, ANTUÉRPIA, HAMBURGO.

3.1 A VIDA EM AMSTERDÃ

3.2. AS CONEXÕES DAS REDES

3.3 GENTE DA NAÇÃO. 146

3.4 A IMPORTÂNCIA DO NÚCLEO FAMILIAR . 153

3.5 A ASSOCIAÇÃO COM OS NÃO SEFARDITAS 171

3.6 O COMÉRCIO ENTRE OS DA NAÇÃO 176 CONSIDERAÇÕES FINAIS 179

FONTES E BIBLIOGRAFIA 184 


\section{Resumo}

A expansão marítima dos séculos $\mathrm{XV}$ e $\mathrm{XVI}$ reconfigurou as atividades mercantis na Europa e levou a difusão dos centros de comércio e das fontes de mercadorias em novas praças na Ásia, na América e na África. O trato transcontinental e as finanças, que ganharam complexidade, concretizaramse nas relações entre as redes de comércio com atuação global.

Portugal foi o nascedouro de grande parte dessas redes familiares que se multiplicaram e passaram a ter negócios em todas as frentes do trato colonial. No início do século XVII, os grandes cabedais lusos transferiram-se para Amsterdã e Hamburgo.

Famílias cristãs-novas destacaram-se no trato mercantil, entre elas a dos Dias de Milão - perseguida e presa pela Inquisição —, que reapareceu em Amsterdã e Hamburgo com grande atuação no comércio internacional.

Palavras-chave: comércio, cristão-novo, Portugal, Amsterdã, Hamburgo, redes de comércio, colônia, família Dias de Milão. 


\section{Abstract}

The maritime expansion that occurred during the $X V$ and $X V I$ centuries reconfigured the mercantile activities in Europe and led to the dissemination of commercial centers and sources of commodities on new places of Asia, America and Africa. The transcontinental treat and finances gained complexity that substantiated itself in global trade networks.

Portugal was the incubator of a great deal of those multiplying family networks that started to have businesses in all fronts of the colonial treat. At the beginning of the XVII century, the great Portuguese estates were transferred to Amsterdam and Hamburg.

New-Christian families had significant importance in commercial dealings, among them the Dias de Milão family, persecuted and arrested by the Inquisition that reappeared in Amsterdam and Hamburg with great outwork on international commerce.

Key words: commerce, New-Christian, Portugal, Amsterdam, Hamburg, commerce networks, trade networks, colony, family Dias de Milão. 


\section{Introdução}

Desde o início da pós-graduação, voltamo-nos para as questões de financiamento da ocupação e da colonização no Brasil, quando a empresa açucareira começou a ser montada e se desenvolveu no Nordeste, a partir de meados do século $\mathrm{XVI} .{ }^{1} \mathrm{O}$ foco estava em talvez poder desvendar as origens dos cabedais investidos na colônia, que possibilitaram o desenvolvimento da cultura sacarina. A quem eles pertenciam? Essa questão foi o ponto de partida para o mestrado.

Celso Furtado afirmou serem os recursos investidos no Brasil de origem flamenga, em especial, holandesa. ${ }^{2}$ A produção açucareira era negócio complexo, pois implicava a plantação de cana, na construção de engenho, além de exigir grande quantidade de mão de obra. A montagem desse empreendimento requeria recursos vultosos na sua implementação para garantir sua continuidade.

Ambrósio Brandão, senhor de engenho e autor dos Diálogos das Grandezas do Brasil, calculava que para se montar um engenho eram necessários mais ou menos 10000 cruzados, ${ }^{3}$ enquanto Godinho considera que "ao todo uns 40000 cruzados, que subirão facilmente a 45000 ou mesmo 50000 se o engenho for maior e empregar mão de obra mais numerosa". ${ }^{4} \mathrm{Em}$

${ }^{1}$ Silvia Carvalho Ricardo. As redes mercantis no final do século XVI e a figura do mercador João Nunes Correia. Dissertação (Mestrado em História Econômica), Faculdade de Filosofia, Letras e Ciências Humanas, Universidade de São Paulo, São Paulo, 2007.

${ }^{2}$ No entender de Celso Furtado, "parte substancial dos capitais requeridos viera dos PaísesBaixos. [...] Tudo indica que capitais flamengos participaram no financiamento das instalações produtivas no Brasil, bem como na importação da mão de obra escrava. [...] poderosos grupos financeiros holandeses, interessados como estavam na expansão das vendas do produto brasileiro, seguramente terão facilitado os recursos requeridos para a expansão da capacidade produtiva." Celso Furtado. Formação Econômica do Brasil. São Paulo: Companhia Editora Nacional, 1991. p. 11.

${ }^{3}$ Ambrósio Brandão. Diálogos das Grandezas do Brasil. Recife: Massangana, 1997. P. 96-97.

${ }^{4}$ Vitorino Magalhães Godinho. Os descobrimentos e a economia mundial, op. cit., v. 2, p. 110. 
1583-84, os senhores de fazendas em Pernambuco tinham cabedais que variavam entre 40.000 e 80.000 mil cruzados.

O aprofundamento das leituras foi nos levando aos primórdios da empresa açucareira em Pernambuco e aos trabalhos historiográficos relativos ao tema, que apontavam a presença dos capitais do norte da Europa, muitas vezes associados a capitais genoveses. É o caso de Stuart B. Schwartz em Segredos Internos, indicando que eles teriam origem no norte da Europa, muitas vezes associados a capitais genoveses; ${ }^{5}$ Kollebenz endossa a participação dos flamengos, demonstrando que em meados do XVI estavam estabelecidos no Brasil senhores de engenho ligados a homens ou grupos financistas de Antuérpia. O Engenho dos Erasmos, em São Vicente, era de propriedade dos Schetz, senhores de Grobbendock, proprietários de uma das principais casas comerciais de Antuérpia no século $\mathrm{XVI}$, com interesses comerciais por toda a Europa. ${ }^{6}$

Pernambuco em meados do século XVI despontava como o polo açucareiro da Colônia. Ricos mercadores e financistas portugueses de origem cristã-nova foram atraídos pelo negócio do açúcar e pelas grandes possibilidades de ganho que ele oferecia. Esses mercadores tiveram intensa participação na implementação e desenvolvimento da empresa açucareira, investindo capitais diretamente na produção, financiando a construção de engenhos e a compra de mudas de cana. Além disso, dominavam a venda de insumos essenciais para a lavoura de açúcar e em segmentos vitais ao escoamento da produção, como, por exemplo, peças náuticas de reposição. A

\footnotetext{
5 Stuart B. Schwartz. Segredos Internos. Engenhos e escravos na sociedade colonial. 15501835. São Paulo: Companhia das Letras, 1999, p. 218-229.

${ }^{6}$ Hermann Kellenbenz, Relações econômicas entre Antuérpia e o Brasil no século XVII. Revista de História. Vol. XXXVII, no 76, São Paulo, 1968, p. 231; 295.
} 
participação desses homens de negócio no tráfico negreiro foi importante para o abastecimento de mão de obra para as lavouras de cana. Detentores de conhecimentos prévios no fabrico do açúcar na Madeira garantiam o funcionamento da produção e a lucratividade do trato açucareiro. ${ }^{7}$ As famílias mercantis portuguesas disponibilizaram para os plantadores de cana de açúcar créditos com base em pagamento após as colheitas para a compra de quatro mil escravos/ano, ao custo de 400 mil cruzados. $^{8}$

Cabedais de origem portugueses, com ramificações ou sediados em Antuérpia, eram investidos diretamente na produção e na comercialização do açúcar do Brasil, como também na construção de engenhos, maquinários, compra de mudas e safras e o escoamento da produção aos menos abastados ou em dificuldades financeiras. Esses grupos de origem cristã-nova atuavam e investiam nos mais significativos e relevantes negócios do período, fosse na África, Brasil ou Ásia. ${ }^{9}$

Homens de grandes cabedais e membros dos clãs mercantis de origem cristã-nova fixaram-se no Brasil organizados em relações familiares que se concretizavam em relações comerciais. Os cristãos-novos portugueses destacaram nessa empreitada além-mar, como senhores de engenhos e, principalmente, no controle do negócio do açúcar. Alternavam-se em posições estratégicas no Brasil, Portugal e África, bases do trato açucareiro e negreiro, mantendo grandes ligações com o Reino, Antuérpia e Amsterdã. ${ }^{10}$

\footnotetext{
7 James C. Boyajian. Portuguese bankers at the Court of Spain 1626-1650. New Jersey: Rutgers University Press, 1983, p. 26-27.

${ }^{8}$ Idem, p. 10.

${ }^{9}$ Leonor Freire Costa. O transporte no Atlântico e a Companhia Geral do Comércio do Brasil. V. 1. Lisboa: CNCDP, 2002; James Boyajian. Portuguese Bankers at the Court of Spain 1626-1650, op. cit, p. 35.

${ }^{10}$ Maria Leonor Freire Costa. A rota do Cabo e as rotas do Brasil: para um estudo comparado do transporte marítimo nos séculos XVI e XVII. Texto apresentado no Seminário $O$ mundo que o português criou: Brasil século XVI. Fundação Joaquim Nabuco: Recife, out. 1997; José Antonio
} 
As redes de comércio transcontinentais agiam em larga escala, fazendo negócios com os produtos coloniais que apresentavam maior rentabilidade. Os laços familiares eram considerados sinônimo de confiança, sendo os membros de uma mesma família ${ }^{11}$ colocados em posições chave de agenciamento ou representação nas principais casas comerciais e financeiras, de acordo com a estratégia de negócio de determinada casa. A participação dos cristãos-novos na economia Atlântica foi mais significativa do que se supõe, destacando-se no financiamento da empresa colonial. Famílias de comerciantes de Lisboa e o Porto, detentoras de grandes cabedais, investiram no Brasil e no comércio do Atlântico. Pernambuco, o mais importante polo açucareiro, desenvolveu-se graças ao suporte das famílias portuguesas com experiência anterior na produção e fabricação de açúcar na Madeira. Entre eles estavam os Fernandes Camaragibe de Olinda e Camaragibe, os Dias Henriques e Dias Santiago, Brandão, Vaaz, Galegos, Milão. Na Bahia estiveram presentes os Lopes Ulhoa, Nunes de Matos, Dias Henriques. Eles e seus descendentes tiveram papel preponderante nos primórdios e no desenvolvimento da empresa açucareira, no comércio Atlântico ${ }^{12} \mathrm{e}$, mais tarde, nos asientos. ${ }^{13}$

Começamos nosso estudo no mestrado pelo comerciante João Nunes Correia, pertencente à elite cristã-nova portuguesa, que veio para Pernambuco e se tornou senhor de engenho, contratador de pau-brasil e asientista. Dono de uma imensa fortuna era membro de uma rede de comércio com ação transcontinental, interligada aos mais importantes mercadores portugueses.

Gonsalves de Mello. Gente da Nação: Cristãos-novos em Pernambuco, 1542-1654. Recife: Fundação Joaquim Nabuco; Massangana, 1989.

${ }^{11}$ Família é um conceito amplo e elástico. Neste trabalho, as relações familiares designarão as relações de consanguinidade direta, vertical e horizontal (pais, avós, irmãos, tios, primos), e também a parentela colateral, sem consanguinidade, estabelecidas pelo casamento (cunhados, sogros).

${ }^{12}$ James C. Boyajian. Portuguese Bankers at the Court of Spain, op. cit., p. 83.

${ }^{13}$ Asientos eram contratos feitos pela Coroa espanhola com comerciantes que lhes davam o direito de exploração do tráfico negreiro. Os asientistas podiam repassar licenças a outros mercadores. 
Perseguido pela Inquisição foi preso em Pernambuco em 1591. Ao chegar a Lisboa, em janeiro de 1592, foi absolvido pelo Tribunal do Santo Ofício por falta de provas. A fiança estabelecida foi de quatro mil cruzados, um valor muito alto, pago por membros da elite lisboeta cristã-nova, entre eles, Henrique Dias de Milão e seu cunhado, o asientista Rodrigo d'Andrade.

Na pesquisa do mestrado, a família Dias de Milão passou a chamar a nossa atenção. Membros da elite mercantil lusa, o segundo maior exportador de açúcar na primeira década do século XVII ${ }^{14}$, os Dias de Milão viveram uma verdadeira saga. Descendentes de judeus espanhóis, o casal Henrique e Guiomar veio de Covilhã para Lisboa. Henrique junto com os cunhados, irmãos e sogro foram para as Índias, onde o sogro e alguns dos cunhados e irmão lá faleceram. Henrique e seu irmão Antonio de Cáceres fizeram fortuna com o trato das especiarias, associando-se aos maiores investidores desse negócio que arremataram o contrato da pimenta na década de 1590, os Duarte Ximenes, seus parentes.

Em 1592, dois dos seus nove filhos encontravam-se em Pernambuco inseridos no comércio do açúcar, e seu genro, junto com o irmão eram donos de engenho. Mais tarde, outro filho se juntará aos Milão em Pernambuco como caixeiro de Manuel Dias de Milão.

A dinâmica econômica em expansão movimentava as redes em um ritmo que exigia a mobilidade de seus membros, caracterizando-as por isso. Ao mesmo tempo, novas praças se abriam ou ganhavam importância e os aprendizes do trato, familiares treinados para esse fim ocupavam esses postos. As redes familiares se firmavam no trato e nas finanças internacionais e eram

\footnotetext{
${ }^{14}$ José Antonio Gonsalves de Mello. Gente da nação: cristãos-novos em Pernambuco, 15421650. 1542-1654.2a ed. Recife, FUNDAJ; Massangana, 1996, p. 32.
} 
interdependentes, ora convergindo, ora divergindo, havendo concorrência entre elas, não sendo homogêneas como grupo todo o tempo, devido a interesses particulares e locais, mas eram restritas a uma elite interligada pela parentela que fazia fortuna.

As casas comerciais com mais destaque dedicavam-se aos vários ramos do trato, e o acesso à prata espanhola foi facilitado com a União Ibérica (15801640), período no qual as Coroas portuguesa e espanhola estiveram unidas. Nesse período, embora as redes formassem o corpo do comércio em expansão, suas ações eram fortemente determinadas pelas ações da Coroa. A Coroa, por sua vez, necessitava dos cabedais dos grandes mercadores e financistas membros da elite portuguesa, visto que a precariedade das finanças régias a obrigava, com frequência, a recorrer a esse tipo de financiamento. No período estudado, foram três bancarrotas e em muitas outras necessitou de recursos imediatos para aliviar seus grandes déficits.

Em 1606, os Milão estavam ligados aos negócios do açúcar em Pernambuco, da prata no México, dos escravos em Angola e da redistribuição do açúcar em Hamburgo e Antuérpia. Henrique era contratador das terças junto com um sócio talvez até mais rico e poderoso do que ele, mas ambos deviam muito dinheiro à Coroa. ${ }^{15}$ Henrique filhos, primos e amigos planejaram a fuga para Hamburgo com toda a família, para irem ao encontro da filha que acabara de casar com o riquíssimo mercador judeu português Álvaro Diniz. Só ficaria em Lisboa Paulo de Milão, filho de Henrique, para cuidar dos negócios da família. $^{16}$

15 Antonio Borges Coelho. Política e fé: cristãos-novos nos Tempos dos Filipes. Cadernos de Estudos Sefarditas. n 1. Lisboa: Cátedra Alberto Benveniste, 2001. p. 111-112.

${ }^{16}$ ANTT. Inquisição de Lisboa. Processo 7890. 
Os Milão foram avisados que estavam para ser presos por altos funcionários régios ${ }^{17}$ e quando estavam embarcados já no Tejo, para serem levados na caravela que os levaria a Hamburgo, foram todos presos pelo Santo Ofício, acusados de judaísmo. ${ }^{18}$

Permaneceram nos cárceres da Inquisição até o auto de fé de outubro de 1609, quando foram penitenciados. Henrique e seu empregado que o denunciara foram relaxados na fé em $1609 .{ }^{19}$ A mulher, filhos e a futura nora de Henrique cumpriam pena no bairro penitencial, em Lisboa, mas conseguiram fugir, deslocando parte da família para Amsterdã e outra pra Hamburgo, onde assumiram a fé judaica. ${ }^{20}$

Em Amsterdã, Gomes Dias de Milão tornou-se Daniel de Olanda e um dos mais importantes mercadores da Nação Portuguesa. ${ }^{21}$ Juntamente com seu primo Francisco de Cáceres, no Porto, ${ }^{22}$ o cunhado Álvaro Diniz, em Hamburgo, ${ }^{23}$ os primos Jorge e André d'Andrade em Antuérpia, a rede retomou seu papel de grande destaque na mercancia internacional. Partimos da hipótese que as redes mercantis formadas pelos cristãos-novos portugueses consolidaram-se e ampliaram-se no trato açucareiro atlântico e se mantiveram, em essência, estruturadas como grupos étnicos. Esse nível de solidariedade,

${ }^{17}$ ANTT. Inquisição de Lisboa. Processo 2523.

18 ANTT. Inquisição de Lisboa. Processo 3366; Antonio Borges Coelho. Política e Fé: CristãosNovos nos Tempos dos Filipes. Cadernos de Estudos Sefarditas, op.cit, p. 122-113; Herman Prins Salomon. Portrait of a New Christian, Fernão Álvares Melo, 1569-1632. Paris; Fundação Calouste Gulbenkian, Centro Cultural Portugués, 1982.p. 108-132.

${ }^{19}$ Herman Prins Salomon. Portrait of a New Christian, Fernão Álvares Melo, 1569-1632. Paris; op.cit.p. 129-132.

${ }^{20}$ Florbela Veiga Frade. As Relações Econômicas e Sociais das Comunidades Sefarditas Portuguesas. O trato e a família, 1532-1632. Lisboa, 2006. [Tese de Doutoramento] Faculdade de Letras da Universidade de Lisboa. p. 245-251.

${ }^{21}$ Studia Rosenthaliana 351.

${ }^{22}$ ANTT. Inquisição de Lisboa. Processo 10600.

23 Florbela Veiga Frade. As Relações Econômicas e Sociais das Comunidades Sefarditas Portuguesas:O trato e a família, op.cit, p. 245-249 
baseado em laços familiares, constituiu-se no principal fator de sua manutenção e sobrevivência.

Este trabalho centra-se no estudo dessa família, como parâmetro das redes de comércio em fins do século $X V I$ e início do XVII. $A$ análise documental desse período é difícil em virtude da precariedade das fontes, em especial a coincidência de nomes, muito comum naquela época, que levantam dúvidas sobre os às informações vindas dos processos inquisitoriais, que muitas vezes são contraditórias, cruzando-se confissões dadas por parentes próximos, provavelmente em virtude da situação em que se encontrava o réu e mesmo ter sido obtida por meio de tormento.

Dividimos o trabalho em três capítulos:

No capítulo 1, conceituamos redes de comércio para podermos situar como a dinâmica econômica se concretizava e como os cristãos-novos nelas se encaixam. Em seguida, tratamos da diáspora cristã-nova na Europa e no Brasil, voltando-nos para as questões econômicas que subsidiaram os caminhos tomados pelos conversos, depois que a repressão inquisitorial se fez presente em Portugal. Analisamos a ascensão da elite mercantil cristã-nova no trato europeu e a comunidade sefardita. Abordamos a participação das redes no comércio luso no Oriente, a ascensão de Antuérpia como centro de distribuição das mercadorias coloniais e Portugal perdendo, assim, a primazia no trato europeu.

O Atlântico Sul, na metade do XVI, tornou-se o pilar do comércio luso, em virtude da expansão da empresa açucareira e do tráfico negreiro que abastecia as lavouras, em especial o Brasil de mão de obra, sendo o tráfico um dos mais importantes e lucrativos negócios do período. O empreendimento 
colonizador foi repassado a particulares em virtude das precárias condições do tesouro real. Ao contrário das Índias, onde a atividade dos europeus circunscreveu-se à circulação de mercadorias, as Ilhas e o Brasil para serem inseridos na economia mercantil lusa foram ocupados e passaram à esfera da produção, como forma de valorizá-las em termos econômicos, atendendo às necessidades mercantis do Estado e dos comerciantes atrelados a ele. Nesse contexto, as redes de comércio tiveram grande participação para que isso se concretizasse.

No capítulo 2, focamos o trabalho na rede de comércio formada pelos Dias de Milão. Buscamos as origens da família Dias de Milão que remonta à Inquisição espanhola. A migração dos seguidores da Lei de Moisés para Portugal obrigou pessoas abastadas e que ocupavam altos cargos junto à corte dos reis católicos deixarem a Espanha. Duas famílias se uniram em Portugal e deram início ao mais poderoso clã ${ }^{24}$ de seu tempo (os Ximenes de Aragão e os Coronel), de quem Guiomar, esposa de Henrique, era descendente direta. Estudamos as relações parentais e a consanguinidade das redes familiares de comércio, bem como sua afirmação e ampliação por meio de matrimônios entre aparentados, consolidavam interesses econômicos.

Procuramos identificar a rede comercial de Henrique Dias de Milão, destacando seus diversos negócios, suas interligações com o açúcar, pimenta, pau-brasil, tráfico de escravos, prata mexicana e suas conexões comerciais com elementos dos mais destacados clãs mercantis lusos dirigidos a partir de Antuérpia, Porto, Pernambuco, México e Amsterdã. Dedicamos especial atenção aos homens/famílias pertencentes a redes de comércio e as relações

\footnotetext{
${ }^{24}$ Clã grupo de pessoas unidas por parentesco e linhagem, definido por um ancestral em comum.
} 
entre eles na atividade mercantil, procurando dar uma visão mais ampla do intricado sistema de conexões parentais que dominava o comércio em fins do século XVI e início do XVII.

Uma das características das redes era a mobilidade de seus membros, que se deslocavam com grande facilidade. Procuraremos entender essa mobilidade visto que havia restrições para os cristãos-novos para que deixassem o Reino na maior parte do tempo no período estudado.

No capítulo 3, partimos da fuga da família Dias de Milão para Amsterdã e Hamburgo que abre outro momento na história da família. Trata-se de um renascer econômico centrado em Amsterdã, no Porto e em Hamburgo, com ramificações em outras praças europeias. Procuraremos entender como se deu essa nova dinâmica, em que bases ela esteve assentada, e como a família agora judia relacionava-se com seus pares e aqueles que vão se incorporando às redes em um momento de expansão comercial. 


\section{Capítulo 1}

\section{Mercadores, banqueiros, financistas no Império Português}

Entre 1450 e 1550, a expansão ultramarina e as atividades mercantis que dela se originaram marcaram o Reino Português que construiu um império transcontinental. Os portugueses tomaram posições territoriais na África e, sobretudo, na Ásia. Fundaram uma rede interconectada pela via marítima de fortalezas e feitorias nesses continentes. ${ }^{25}$ No último quartel do século $\mathrm{XV}$, o comércio português ampliou-se com o ouro, marfim, pimenta malagueta e escravos provenientes da Mina e Guiné, na costa ocidental da África, e o açúcar e as madeiras das llhas atlânticas. ${ }^{26}$ Em virtude da importância das mercadorias africanas para o trato português, e como forma de assegurar 0 fluxo do ouro diretamente para Portugal, evitando assim, a rota tradicional terrestre pelo Saara, D. João II, em 1482, mandou construir uma fortaleza na Guiné, a de São Jorge da Mina, que servia de base para as tocas com africanos e protegia os interesses lusos. ${ }^{27}$

A expansão ultramarina transformou o reino português em um império marítimo, "quase sem territorialidade", visto que o "império" apoiava-se suas rotas comerciais em ilhas, portos e regiões costeiras dos continentes africano,

25 Vitorino Magalhães Godinho. Os descobrimentos e a economia mundial. v. 1. Lisboa: Presença, 1987. p. 102-108.

${ }^{26}$ A. A. Marques de Almeida. Capitais e capitalistas no comércio da especiaria: o eixo LisboaAntuérpia (1501-1549). Lisboa: Cosmos, 1993. p. 19.

27 Joaquim Romero Magalhães. Portugueses no mundo do século XVI: espaços e produtos. Lisboa: CNCDP, 1998, p. 15. 
asiático e americano. ${ }^{28} \mathrm{~A}$ noção de império (no sentido da modernidade do XVIII) que traduz uniformidade, continuidade, dependência e de continuidade territorial não se aplicam ao Império Português até praticamente o final do século XVI. ${ }^{29}$

No caso português, o corpo do Império era o próprio mar, vencido e aberto pelas naus portuguesas. ${ }^{30} \mathrm{O}$ Império surgiu em função do comércio e circulação das especiarias e se firmou como o "Império da pimenta, organizado pela Coroa e submetido a ela." ${ }^{31}$ Sua manutenção deu-se por meio da implantação de uma rede de fortalezas e feitorias que garantiam o tráfego das mercadorias pelos oceanos Atlântico e Índico, além da presença da frota naval militar que vigiava os postos fortificados.

Nas primeiras décadas do século XVI, a presença portuguesa no Índico era expressiva e crescente. Os lusos provocaram significativas mudanças no antigo comércio Oriente-Europa que ia desde a China, passando por Alexandria, desembocando no Mediterrâneo. O produto de maior destaque era a pimenta que garantia imensas margens de lucros.

Entre 1500 e 1530, a Rota do Cabo suplantou amplamente a Rota do Levante como principal fonte de fornecimento de especiarias à Europa. A armada portuguesa conseguiu bloquear, em grande parte, a passagem para 0

${ }^{28}$ João Paulo Oliveira e Costa. O Império português em meados do século XVI. Anais de História de Além-mar. Lisboa: Centro de Histórias de Além-mar; Universidade Nova de Lisboa, 2002, v. 3, p. 87.

${ }^{29}$ A. J.R. Wood. Os Portugueses fora do Império. In: Francisco Bettencourt, Kirti Chauduri. História da Expansão Portuguesa. V1. A formação do Império (1415-1470). Navarra: Círculo de Leitores, 1998, p. 256.

${ }^{30}$ António Manuel Hespanha. Panorama da história institucional e jurídica de Macau. Macau: Fundação Macau, 1995. Apud OLIVEIRA, F. R. de. Os portugueses e a Ásia marítima, c.1500-c.1640: contributo para uma leitura global da primeira expansão européia no Oriente. $2^{\text {a }}$ Parte: o Estado Português da Índia. Scripta Nova: Revista Electrónica de Geografía y Ciencias Sociales. Barcelona: Universidad de Barcelona, v. 7, n. 152, 2003. Disponível em: <http://www.ub.es/geocrit/sn/sn-152.htm>. Acesso em: 16 abr. 2014.

31 Joaquim Romero Magalhães. Açúcar e especiarias. In: Francisco Bettencourt; Kirti Chaudhuri (Dir.). op. cit., v. 1, 55; 61. 
mar Vermelho. ${ }^{32}$ Assim, apossaram-se de parte do trato que antes era feito pelo Mediterrâneo e que abastecia a Europa, atraindo as principais famílias de negociantes e banqueiros alemães e italianos. As naus com as cargas das especiarias começaram a chegar a Lisboa em 1506. A mercadoria era depositada na Casa das Índias (fundada em 1501) sob responsabilidade do rei, e daí reexportada para toda a Europa ou enviada para Flandres. ${ }^{33}$

Antuérpia já realizava feiras de comércio no final do século $X V$ e foi escolhida, em 1498, para sediar uma feitoria portuguesa que garantisse a distribuição e abastecimento do norte da Europa, centro estratégico para as áreas circundantes e próximas dos mares do Norte e o Báltico dos produtos do monopólio real colonial.

A fragilidade da Rota do Cabo e o aumento da debilidade financeira do tesouro real fizeram com que, aos poucos, Portugal fosse obrigado a ir abandonando as praças marroquinas e até chegar fechar a feitoria em Antuérpia em 1549. As autoridades lusas queriam disponibilizar e concentrar capitais em Lisboa para fazer frente aos mercadores estrangeiros que se estabeleceram em Portugal, já infiltrados no trato, mas com possibilidades dele se apoderar. ${ }^{34}$

No reinado de D. Sebastião (1568-1578) discutia-se "sobre em quais alicerces o império ultramarino deveria se basear prioritariamente: se na Índia ou no Atlântico (Brasil e África)". ${ }^{35}$ Nas Cortes de 1562-63 já se considerava "mais justa, e mais conveniente, a conquista de África, que a da Índia; e a razão era, porque esta estava muito longe, e não rendia coisa, que com ela se

\footnotetext{
${ }^{32}$ Idem. p. 303.

${ }^{33}$ Joaquim Romero Magalhães. Portugueses no mundo, op. cit., p. 86.

${ }^{34}$ A. A. Marques de Almeida. Capitais e capitalistas, op. cit., p. 21-22.

35 Joaquim Romero Magalhães. Portugueses no mundo, op. cit., p. 87.
} 
não tornasse a gastar, e aquela estava perto". ${ }^{36}$ Neste contexto, percebe-se uma atlantização cada vez maior da política ultramarina, e sob as ordens do Desejado, seriam tomadas medidas para aprofundar a presença lusa em Angola e na América portuguesa". ${ }^{37}$

\subsection{As redes de comércio}

Redes transcontinentais de comércio firmaram-se como elementos vitais para a expansão e solidificação das atividades mercantis. Elas eram formadas por grupos de comerciantes de grosso trato capitaneadas por cristãos-novos ${ }^{38}$ que se uniam para viabilizar o comércio, num cenário que Braudel $^{39}$ já caracterizara como o momento do boom dos judeus sefarditas. ${ }^{40}$

Os homens que constituíam as redes de comércio eram pessoas com interesses no comércio e com o objetivo de enriquecer na segunda metade do século $\mathrm{XVI}$, período que já se consolidava a colonização na América. A colonização deve ser entendida como um desdobramento da expansão comercial europeia, imbricada à expansão do capitalismo comercial. ${ }^{41}$

Segundo Fernand Braudel, o universo comercial entre os séculos XVI e XVIII cobria o mundo de pequenas quadrículas e em cada encruzilhada e que

\footnotetext{
${ }^{36}$ Idem.

${ }^{37}$ Fernando Salles Loureiro. A alteração das coordenadas da política de expansão portuguesa na segunda metade do século XV. Actas das Primeiras Jornadas de História Moderna. Lisboa: Centro de História da Universidade de Lisboa, 1986, v. 1, p. 259-273.

${ }^{38}$ Cristãos-novos referem-se a todos aqueles batizados depois da conversão forçada em 1497.

${ }^{39}$ Fernand Braudel. Jogo das trocas. Civilização material, economia e capitalismo: séculos XV - XVIII. Trad. Telma Costa. São Paulo: Martins Fontes, 1995, v.2, p.134-136.

${ }^{40} \mathrm{O}$ termo sefardita refere-se aos judeus que se refugiaram na Península Ibérica depois da destruição do templo de Jerusalém, e que ao longo do tempo se estabeleceram nas costas do Mediterrâneo, especialmente, Portugal e Espanha. Cultivavam seus próprios hábitos, tradições, língua, entre outras tradições culturais, diferentes dos askenazis que se concentrara na Europa central.

${ }^{41}$ Fernando A. Novais. Portugal e Brasil na crise do Antigo Sistema Colonial (1777-1808). 6. ed. São Paulo: Hucitec, 1985, p. 54.
} 
em cada escala existiria um mercador que aí estava sediado ou por aí passava. ${ }^{42}$ As redes tinham um caráter geográfico, no qual certo número de indivíduos ou agentes alocados em diferentes pontos em um circuito ou grupos de circuitos. Nessa estrutura, a cooperação, comunicação e a conexão entre eles garantiam a continuidade e a prosperidade dos negócios. ${ }^{43}$ Braudel destacou a sofisticada organização dos mercadores no Oceano Índico, em particular para a importância do sistema de trocas monetárias hindus, quando do contato dos europeus com o Oriente no século XVI. Diferentes grupos de mercadores formavam "nações" que eram responsáveis pela criação e tinham o domínio dos "circuitos e redes", 44 estando entre os mercadores dessas nações, armênios, genoveses, florentinos e também chineses, japoneses e indianos estabelecidos em redes muito antes dos europeus. ${ }^{45}$

O foco do trabalho está voltado para a dinâmica mercantil no Atlântico e das redes de comércio que nele atuavam, e em especial as formadas por judeus e portugueses cristãos-novos. ${ }^{46}$ Os homens que se uniam em redes de comércio com ação transcontinental, lideradas por cristãos-novos portugueses formavam a elite mercantil europeia e mundial. Participavam do comércio da pimenta e das especiarias no Oriente, do açúcar e do tráfico negreiro no Atlântico. Seus cabedais avultaram-se significativamente com a mercancia açucareira, quando fortunas foram feitas e se tornaram sustentáculo de um

${ }^{42}$ Fernand Braudel. O Jogos das Trocas. Civilização Material, Economia e Capitalismo. Séculos XV-XVIII, op.cit. p. 129.

${ }^{43}$ Idem, p. 132.

44 Segundo Braudel, a atividade econômica desenvolve-se como em um circuito elétrico, estando em cada uma das pontas o produtor e o consumidor. A ligação entre eles se dá como em uma corrente elétrica, sendo a mercadoria conduzida ao consumidor, não havendo retorno. Essa dinâmica, no entanto, só funciona plenamente, quando o circuito se encerra, como em um circuito elétrico. Cabe ao capital fazer o retorno e promover o equilíbrio do conjunto, fechando, assim, o circuito comercial, é o capital o óleo que lubrifica o circuito comercial. Fernand Braudel, idem, p. 314 et. seq.

${ }^{45}$ Fernand Braudel, op. cit., p. 166.

${ }^{46}$ Idem, p. 166-176. 
grupo financistas de cristãos-novos que socorreram a Coroa espanhola na década de 1620, quando esta entrou em bancarrota. ${ }^{47}$

As questões de identidade em comunidades e atores históricos, e a sua relação com a constituição de redes, foram assumidas por historiadores cujos trabalhos se debruçaram sobre as comunidades mercantis em diáspora, sendo os casos mais conhecidos os dos judeus e dos armênios. Deste grupo, sobressaem-se as contribuições de Miriam Bodian e Jonathan Israel. ${ }^{48}$ Ambos defendem a concepção de rede radicada em comunidades formadas por indivíduos que partilham o mesmo substrato cultural, representado primeiramente por uma prática linguística e religiosa.

Nessa visão, o amálgama das redes de comércio, lideradas pelos sefarditas portugueses era os laços de família, relações parentais de caráter sócio étnico e religioso, base sólida nas quais se formaram e desenvolveram as redes de comércio. Para Jonathan Israel, o sucesso e a eficiência das redes de comércio sefarditas estão intimamente ligados a uma comunidade internacional religiosa e culturalmente unida, ${ }^{49}$ nas quais o conhecimento e a confiança depositada nos seus membros e parceiros comerciais eram fundamentais para que as redes evoluíssem e pudessem se alargar. ${ }^{50}$

Daniel Swetschinski aproxima-se de Jonathan I. Israel e defende a importância da parentela nas redes sefarditas no seu estudo sobre os cristãos-

${ }^{47}$ James C. Boyajian. Portuguese Trader in Asia under the Habsburgs 1580-1640. Baltimore: Johns Hopkins University Press, 1993, p. 132.

${ }^{48}$ Miriam Bodian. Hebrews of the Portuguese Nation: Conversos and Community in Early Modern Amsterdam. Bloomington: Indiana University Press, 1997; Jonathan I. Israel. Diasporas within a Diaspora: Jews, Crypto-Jews and the World Maritime Empires (1540-1740). Leiden: Brill, 2001.

49 Jonathan I. Israel. Introduction In: Jonathan I. Israel, Diasporas Within a Diaspora: Jews, Crypto-Jews, and the World of Maritime Empires 1540-1740... op.cit.

${ }^{50}$ Bernard Bailyn. The New England Merchants in the Seventeenth Century. Cambridge, MA: Harvard University Press, 1955. 
novos portugueses em Amsterdã. ${ }^{51}$ Deixa clara a primazia das relações de parentesco no trato mercantil, especificamente em relação aos sefarditas portugueses, embora tenha reconhecido a necessidade da inclusão pessoas de fora desse grupo étnico-religioso, para a existência e funcionamento das redes de comércio.

James C. Boyajian também ressalta a importância das relações de sangue e do casamento entre a comunidade cristã-nova na configuração das redes de comércio responsáveis pela realização dos negócios na Ásia e com o açúcar brasileiro. ${ }^{52}$

Uma das estratégias para a coesão e manutenção das redes formadas pelos cristãos-novos lusos era o casamento endogâmico. Assim, a aliança nupcial era uma redução de risco e estratégia comercial das redes de negócio. Um mercador e sua família estabeleciam alianças com outras famílias com as quais compartilhavam fortes interesses comerciais. $O$ fator mais importante para as relações econômicas e sociais era o parentesco e esta foi a base de sustentação do próprio comércio $^{53}$ do início da Idade Moderna. As redes parentais se mantinham dando continuidade aos negócios da família. Aproveitava-se o conhecimento adquirido no trato, bem como a clientela e os fornecedores e as relações estabelecidas com estes. Para ser aceito como membro de uma casa comercial, era comum que o pretendente necessitasse de boas referências de familiares próximos ou mais distantes, o que podia determinar seu sucesso profissional.

\footnotetext{
${ }^{51}$ Daniel Swetschinski. Kinship and Commerce - The Foundations of Portuguese Jewish Live in $17^{\text {th }}$ Century Holland. In: Studia Rosenthaliana, v. 13, n. 2, 1979, p. 52-74.

52 James C. Boyajian, Portuguese Trade in Asia under the Habsburgs 1580-1640, op. cit. p. 206.

${ }^{53}$ Daniel Swetschinski, op. cit., p.75.
} 
Graças a essas relações do casamento endogâmico foi possível manter a riqueza e os capitais dentro das famílias cristãs-novas e impedir o alargamento dos clãs. Esses homens eram, antes de tudo, empreendedores, que procuravam oportunidades de investimentos na mercancia em expansão. Eram poucas famílias que dominavam o trato e aparentadas entre si, formando a elite mercantil em Portugal. O levantamento da genealogia de alguns dos principais leva-nos a judeus emigrados da Espanha em 1492, parte deles com destaque na corte espanhola, como os Ximenes de Aragão e Rodrigues d'Évora, ${ }^{54}$ os mais importantes clãs mercadores da segunda metade do século XVI e início do XVII. Além disso, compartilhavam informações, custos de transporte e os de seguros, com forma de contornar os muitos obstáculos que se colocavam nas arriscadas empreitadas marítimas que levavam e traziam mercadorias no trato transcontinental.

Laços de família, mesma condição sócio étnica e religião são vistos como a base da formação de redes de comércio de sucesso eficientes durante esse tempo e lastreiam os trabalhos de Gérard Nahon, The Portuguese Jewish Nation of Saint-Esprit-Lès Bayonne: The American Dimension, ${ }^{55}$ Gente da Nação 56 ; Bernard Bailyn, The New England Merchants in the Seventeenth Century. ${ }^{57}$

54 Florbela Veiga Frade. As relações econômicas e sociais das comunidades sefarditas portuguesas: o trato e a família: 1532-1632. Tese de doutorado, História (História Moderna), Departamento de História, Universidade de Lisboa, 2006.

55 Gérard Nahon. The Portuguese Jewish Nation of Saint-Esprit-Lès Bayonne: The American Dimension. In: Paolo Bernardini and Norman Fiering, (eds.) The Jews and the Expansion of Europe to the West, 1450 to 1800. New York: Oxford: Berghahn Books, 2001, p. 255-267.

${ }^{56}$ José Antonio Gonsalves de Mello. Gente da Nação: cristãos-novos e judeus em Pernambuco, 1542-1654. Recife: Massangana, 1966, p. 23

57 Bernard Bailyn. The New England Merchants in the Seventeenth Century. Cambridge: Harvard University Press, 1955. 
Foi Philip Curtin quem primeiro estudou as redes de comércio sob a ótica cultural e se referiu às diásporas comerciais como dispersão de grupos homogeneamente culturais em diversos pontos geográficos. ${ }^{58}$ Para ele, a solidariedade entre os integrantes das redes advinha dos elementos culturais comuns e Ihes dava sustentação. O mecanismo de atuação das redes advinha da confiança e da boa reputação adquirida. ${ }^{59}$ As diásporas comerciais como comunidades e/ou redes morais, embora vivessem em dispersão, controlavam e moldavam os comportamentos. O foco de Curtin está na ligação intrínseca entre a relação de confiança estabelecida e a identidade comum dos indivíduos, valorizando a si, aos seus pares e ao grupo ligados pelos laços de parentesco, da religião e etnicidade, por meio de ações de coação social e ritual. ${ }^{60}$

Avner Greif estudou a organização comercial dos judeus estabelecidos no Magreb, no norte da África, nos séculos XI e XII, em suas dimensões culturais. Suas análises estavam centradas na forma que as sociedades de mercadores se organizavam: coletivista ou individualista. Na primeira formação, os mercadores faziam suas trocas entre seu grupo étnico e, para tal, havia a necessidade de que os elementos do grupo gozassem de uma boa reputação, sendo as transações asseguradas pela honra recíproca, visto que não havia contratos nem leis que os garantissem. Esses mercadores tendiam a se organizar de maneira horizontal, comerciando entre si sem uma égide hierárquica. No segundo grupo de mercadores, seus componentes atuavam de forma individualista e frequentemente faziam transações comerciais fora de seu Press, 1984

${ }^{58}$ Philip Curtin. Cross-Cultural Trade in world History. New York: Cambridge: University

${ }^{59}$ Idem, p. 3.

${ }^{60}$ Ibidem, p. 18-36. 
grupo étnico. As trocas intragrupos se davam de maneira informal, enquanto as realizadas intergrupos eram cooperativas. ${ }^{61}$ Para ele, as relações informais são a garantia para a estabilidade das redes de comércio.

Daviken Studnicki-Gizbert questionou a abordagem econômica para as organizações empresariais multiculturais conhecidas como redes de comércio, apesar da relevância das instituições informais para a estabilidade das redes de comerciantes. Enfatizou códigos culturais e morais comuns como o principal fator de coesão entre os integrantes das redes, o que tornaria a homogeneidade das raízes sociais uma característica irrelevante das redes de comércio. Para ele, "Parece que os limites dessas redes comerciais foram porosos e admitiram a existência de relações que faziam ponte entre as diferentes nações comerciais." ${ }^{62}$ A reciprocidade, considerada em seus aspectos socioeconômicos, invoca a troca (não necessariamente equitativa) de bens, informação ou capital social. Para que ocorra, é necessário que todos os membros da rede creiam e ajam de acordo com os princípios de reciprocidade. Assim, a confiança vai se estabelecendo entre os participantes, bem como se intensificam a necessidade de relações entre os mesmos.

Para Gizbert, a Nação Portuguesa ${ }^{63}$ era composta por redes heterogêneas que não eram baseadas na religião, nacionalidade ou parentesco e delas faziam parte cristãos-velhos, conversos e marranos. Gizbert ressalta que os cristãos-novos usavam suas conexões comerciais em Portugal, Antuérpia, Amsterdã e Hamburgo para fazer chegar o açúcar do Brasil até o

\footnotetext{
${ }^{61}$ Avner Greif. Contract Enforceability and Economic Institutions in Early Trade: the Maghribi Traders Coalition. The American Economic Review, p. 83, 1998.

${ }^{62}$ Daviken Studnicki-Gizbert. A Nation upon the Ocean Sea: Portugal's Atlantic Diaspora and the Crisis of the Spanish Empire, 1942-1640. New York: Oxford, 2007, p. 71-73.

${ }^{63}$ Para Daviken Studnicki-Gizbert a Nação Portuguesa refere-se aos judeus que deixaram Portugal e Espanha expulsos no século XV e XVI. Trata-se de um subgrupo dos sefarditas os comerciantes que formavam as redes de comércio.
} 
consumidor europeu. Os comerciantes portugueses vieram de um conjunto diversificado de contextos culturais, religiosos e regionais, eles não eram apenas um grupo heterogêneo, mas também um grupo que estava aberto ao contato geográfico e social na formação de seus relacionamentos de negócios. A filiação religiosa de comerciantes portugueses, incluindo os sefarditas, foi heterogênea e fluida. Esses grupos interligavam-se e casavam entre si, havendo grande conexão entre eles. O casamento tinha uma importante função de ligação entre as famílias que compunham uma casa de comércio. Seus parceiros comerciais eram ingleses, alemães, flamengos havendo grandes trocas entre eles. Essas relações foram essenciais para o comércio entre as regiões, setores e culturas. Os comerciantes da Nação Portuguesa não eram provenientes da mesma região em Portugal e cada casa de comércio era constituída por diferentes famílias. Como não havia parentes próximos na família para serem mandados como representante nos locais de interesse estratégico para as casas de comércio, muitas vezes filhos muito jovens eram mandados como aprendizes, para começar suas carreiras no trato. Assim, o parentesco era reforçado nas ligações comerciais pré-existentes. ${ }^{64}$

Os comerciantes precisavam avaliar uns aos outros em termos morais e econômicos antes de se associarem. A reputação estava em primeiro lugar e a interdependência foi crucial para manter o crédito e o movimento das mercadorias que se manteve por muitas gerações. A base para isso era amizade, parentesco, obrigações mútuas criadas pelo dar e receber. Um bom exemplo de interdependência pode ser encontrado no fato de que os comerciantes jovens precisavam de empréstimos dos mais velhos para

\footnotetext{
${ }^{64}$ Daviken Studnicki-Gizbert. A Nation Upon the Ocean Sea: Portugal's Atlantic Diaspora and the Crisis of the Spanish Empire, op. cit., p. 94-95.
} 
começar a desenvolver sua rede em novos locais, abrindo, consolidando ou mantendo mercados.

A honra, a lealdade, a interdependência e o mutualismo foram a base de interação dos grupos que interagiam entre si e formaram relações duradouras, lastreadas na confiança, em uma época em que as instituições políticas e judiciais não eram regidas por leis ou contratos. Cabe ressaltar que, para Studnicki-Gizbert, os mercadores portugueses eram exceção nas estruturas das redes de comércio do século XVII, visto que não centravam suas atividades numa determinada nação-estado, região, cidade. ${ }^{65}$

Daniel Strum, em sua tese de doutorado The Portuguese Jews and New Christians in the Sugar Trade: Managing Business Overseas -Kinship and Ethnicity Revisited, ${ }^{66}$ aborda as redes de comércio seguindo Studnicki-Gizbert destaca a diferença entre os "agentes fixos maiores" e "agentes viajantes menores". Os primeiros eram os comerciantes de grosso-trato, detentores de grandes capitais, basicamente cristãos-novos e os segundos, normalmente escolhidos fora desse grupo étnico, com pequenos capitais, escolhidos conforme sua reputação.

Para ele, numa época em que a falta de ordenamento jurídico impunha que a maneira de se portar e comportar tivesse grande valor em termos sociais, passando a ser balizador a contendas entre membros dos grupos

${ }^{65}$ Os comerciantes portugueses não eram o centro de suas atividades em um determinado Estado-nação, região ou cidade. Nesse aspecto, eles se distinguiram da maioria das outras comunidades mercantis do período. Comerciantes europeus do século XVII geralmente desenvolviam estruturas comerciais que formavam um polo com uma série de raios ramificando-se para mercados secundários [. . .]. Se outras comunidades mercantes foram definidas pela estrutura organizacional por meio de um polo irradiado, os portugueses tinham muitos centros ligados a muitos raios. Daviken Studnicki-Gizbert. $A$ Nation upon the Ocean Sea: Portugal's Atlantic Diaspora and the Crisis of the Spanish Empire, op. cit.p. 96.

${ }^{66}$ Daniel Strum. The Portuguese Jews and New Christians in the Sugar Trade: Managing Business Overseas - Kinship and Ethnicity Revisited (Amsterdam, Porto and Brazil, 1595-1618), Ph.D. diss. Hebrew University of Jerusalem, 2009. 
sociais e dos agentes ligados às atividades econômicas das redes de comércio. As punições e os desvios sociais tinham como base a reputação bilateral e multilateral, o que tornava mais fácil perceber desvios de conduta moral e socialmente inaceitáveis, como a desonestidade, tomar atitudes que viessem a punir aqueles que transgrediam as normas e resolver disputas, garantindo o controle e a eficiência das redes. Dessa forma, não era necessário buscar os membros as redes para compor de comércio no mesmo grupo étnico-religioso. No entanto, ressalta que havia situações nas quais prevalecia a composição sefardita das redes. Para Strum, a comunicação tinha papel primordial nas redes de comércio, sendo uma maneira dos agentes maiores manterem o controle sobre seus agentes nas diferentes praças de comércio transcontinentais. A dinâmica das redes se dava no comércio de longa distância que ora se mesclavam e ora se afastavam, e que tinham interesses concêntricos e divergentes.

Essa dinâmica das redes levava a enfrentamentos entre elas e também à cooperação em determinados momentos, variando e alternando-se no decorrer do tempo. Formavam-se, assim, grandes e complexas teias negociais entre as diferentes e diversificadas redes, visto que estas abarcavam não somente os sefarditas, mas uma gama de grupos étnico-religiosos ligados ao trato.

Leonor Freire Costa em O Transporte no Atlântico e a Companhia Geral do Comércio do Brasil, 1580-1635, analisa a participação de comerciantes portugueses no comércio do açúcar pernambucano, e entre eles vários cristãos-novos. A monumental pesquisa teve como foco a origem da Companhia Geral do Comércio do Brasil. Para Costa, as redes de comércio 
eram tendencialmente dispersas e circulando por conta própria, o que contrasta

com a ação concertada dos holandeses ou ingleses que mais tarde, no século

XVII, tomaram conta do comércio internacional. ${ }^{67}$

A consanguinidade determinou a liderança, a afinidade geográfica e a lateralidade. As relações de parentesco solificavam as redes que transitavam

pelos portos estratégicos, caracterizando a própria dinâmica mercantil. ${ }^{68} \mathrm{Na}$ diáspora portuguesa todos os elementos que compunham a família nuclear normalmente deixavam Portugal outras vezes os casamentos tinham lugar já no território da diáspora, ligando elementos de famílias diversas. Deste modo, por meio do parentesco efetivavam-se verdadeiras redes de poder, muitas vezes ligadas ao comércio. ${ }^{69}$ As relações de parentesco solidificavam as redes que transitavam pelos portos estratégicos, caracterizando a própria dinâmica

${ }^{67}$ Leonor Freire Costa. O Transporte no Atlântico e a Companhia Geral do Comércio do Brasil (1580-1663). op.cit. p.165.

${ }^{68}$ Idem, ibidem, p. 130.

${ }^{69}$ Suzana Mateus em Família e Poder: a importância dos laços de parentesco na construção das redes mercantis sefarditas (séculos XVI e XVII). In: Cadernos de Estudos Serfaditas. Lisboa:, Cátedra de Estudos Sefarditas Alberto Benveniste, 2000. Nesse artigo, ela afirma que os casamentos entre cristãos-novos foram fundamentais para a expansão das redes de comércio e do poder econômico dos clãs mercantis. "Um dos aspectos mais marcantes da organização familiar desta elite mercantil sefardita é a sua tendência para recorrer à endogamia. De fato, à semelhança do que acontece nos grupos nobiliárquicos, estas famílias têm um grande cuidado nas estratégias matrimoniais que desenvolvem, procurando, acima de tudo, a manutenção e a ampliação do seu patrimônio. Quando falamos de endogamia, usamos este conceito num sentido alargado, considerando também os casamentos que se efetuam entre diferentes famílias da elite mercantil sefardita As relações matrimoniais entre importantes famílias mercantis constituem uma forma muito eficaz de ampliação do patrimônio, bem como de aumento considerável de poder econômico. Esta tendência endogâmica nem sempre era fruto de uma ação voluntária, sendo muitas vezes o resultado de diversas conjunturas que condicionavam as estratégias matrimoniais das famílias sefarditas. As restrições impostas pela limpeza de sangue, a necessidade de ocultar práticas criptojudaicas, entre muitos outros fatores, levaram necessariamente a um maior fechamento do grupo. Em consequência de todos estes elementos condicionantes, bem como em resultado da dispersão territorial provocada pela diáspora, não será de estranhar a importância que os laços de parentescos ganham na sustentação das redes comerciais sefarditas. Pelo menos em termos teóricos, as relações de parentesco seriam as relações informais com um maior grau de afetividade e de confiança. Ora, no caso deste mundo mercantil, parece-nos evidente que a confiança seria um fator determinante, nomeadamente nos negócios que envolviam o crédito. Desse modo, as redes comerciais estabelecidas por estas famílias são, em simultâneo, redes familiares, até porque muitas vezes os elementos mais jovens destas famílias recebem instrução desde muito cedo na arte dos negócios, de forma a perpetuarem estas relações cruciais para a manutenção do poder econômico e também político destas famílias.” 
mercantil ${ }^{70}$. As conexões mercantis que resultaram em redes de comércio contavam com a cumplicidade e relações de poder, de parentesco e de tráfico de influências entre a Coroa e os comerciantes de grosso trato, primeiramente ligados ao comércio do Oriente. ${ }^{71}$

David Grant Smith, em sua tese de doutorado The mercantile class of Portugal and Brasil in The Seventheenth: a Socio-Economic of Lisbon and Bahia,1620-1690, mostrou que as redes eram formadas tanto por cristãos velhos como por cristãos-novos. Smith voltou-se aos mercadores cristãos novos e velhos da Bahia, que muitas vezes, se casaram e, essencialmente eram parceiros nos negócios ou praticavam a mercancia de maneira similar. Smith aprofundou seu estudo investigando alguns desses expoentes comerciantes e revelando a dinâmica econômica e social que havia entre eles. $^{72}$

Christopher Ebert estudou o açúcar brasileiro na economia atlântica entre 1550-1630 e cita o parentesco e a identidade religiosa como elementos importantes que ajudaram a cimentar as redes no comércio do açúcar no início da época moderna, não se fixando, no entanto, apenas nos cristãos-novos e judeus portugueses, abordando também, holandeses, alemães e flamengos. Para ele, porém, não se deve afirmar que as redes tenham sido étnicas, conhecidas como redes sefarditas, que realizavam o comércio exclusivo entre portugueses e holandeses. Nelas havia cristãos-novos e velhos ora como

${ }^{70}$ Leonor Freire Costa. O Transporte no Atlântico e a Companhia Geral do Comércio do Brasil (1580-1663). op. cit .p. 131.

${ }^{71}$ Idem, p. 165.

${ }^{72}$ David Grant Smith. The Mercantile Class of Portugal and Brazil in the Seventeenth Century, op. cit. 
parceiros, ora como concorrentes ${ }^{73}$. Com certeza, a religião e o caráter étnico, embora fluídos, tiveram grande importância entre os mercadores, nas suas relações mercantis em meados do século XVII.

Esses elementos, no entanto, não foram determinantes e não se pode reduzir as redes de negócio à identidade religiosa ou étnica. Nesse sentido, Ebert segue Gran Smith e Leonor Freire Costa, afirmando que as redes de comércio, especialmente as ligadas ao comércio do açúcar, às quais dedicou o seu trabalho, eram formadas por cristãos-novos e cristãos velhos. ${ }^{74}$ Afirma que as redes de comércio do açúcar brasileiro caracterizaram-se mais pelos circuitos do comércio do que pelo caráter étnico ou religioso, organizando-se geograficamente em torno do Atlântico, num circuito espacial que se voltava para a Europa, em especial, redistribuído progressivamente pelo norte da Europa. $^{75}$

Florbela Veiga Frade estudou os cristãos-novos, ${ }^{76}$ com foco nas famílias proeminentes e suas relações parentais e parcerias, seus capitais e estrutura de negócios com ênfase no eixo Lisboa - Antuérpia. A partir dos laços de sangue explica a dinâmica da família e também das casas comerciais. Era o núcleo familiar o cerne dos negócios e da estrutura que os regia. Além disso, as relações e a dinâmica entre os núcleos familiares eram responsáveis pela própria configuração da estrutura econômica que era realizada pelas casas de comércio. O líder dessas normalmente pela proximidade e convívio exercia seu poder de controle sobre a parentela mais próxima, dentro de determinada

\footnotetext{
${ }^{73}$ Cristopher Ebert. Between Empires: Brazilian Sugar in the Early Atlantic Economy 1550 1630, op. cit, p. 7.

${ }^{74}$ Ibidem, p. 63-64.

${ }^{75}$ Ibidem. p. 64-66.

76 Florbela Veiga Frade. As relações econômicas e sociais das comunidades sefarditas portuguesas: o trato e a família -1532-1632, op. cit.
} 
hierarquia familiar. Essa proximidade se estendia também aos negócios que eram feitos com os mais próximos, que se confundiam, grande parte das vezes com a parentela.

As funções dentro dessas redes e as colaborações iam desde o núcleo de convivência até os demais membros da família, mais ou menos próximos, independentemente da localização geográfica dos mesmos. O casamento endogâmico era uma estratégia econômica entre clãs para manter e aumentar o patrimônio, os capitais, os bens, o poder conquistado. ${ }^{77}$ Uma das principais estratégias para a continuidade e a consolidação dos negócios foi o casamento endogâmico sefardita. Nesse contexto, o dote assumia um papel preponderante, entre as demais as obrigações recíprocas financeiras envolvidas no casamento, bem como a transferência de bens pessoais, para citar apenas alguns - e acordos vinculativos do contrato de casamento feito esta instituição financeira importante. ${ }^{78}$

No alvorecer da modernidade, ainda se fazia presente grande parte do pensar e fazer medieval, das relações de fidelidade, da honra, das obrigações recíprocas. Portanto, podemos dizer que os laços de confiança que

\footnotetext{
${ }^{77}$ David G. Smith afirmou que: "[...] é natural que eles escolhessem para fazer alianças com as famílias que compartilhavam seus interesses econômicos e sociais. Além disso, esses novos empresários cristãos que permaneceram criptojudeus que corriam grandes riscos consideráveis obviamente preferiram que seus filhos se cassassem em famílias que acreditavam pudessem manter suas crenças e o mesmo processo de marginalização ajudou a perpetuar o marranismo [cripto-judaísmo] entre os cristãos-novos, sem dúvida, reforçou essa tendência ": David Gran Smith, The Mercantile Classe de Portugal e Brasil no século XVII... op.cit. p. 138; Daniel Strum afirma ter encontrado em sua pesquisa um pequeno número de casos de casamentos cristãos-velhos do mesmo ou maior nível socioeconômico e, aparentemente, nenhum com menor; também afirma que foram poucos casos de casamentos entre cristãos-velhos e cristãos-novos Florbela Veiga Frade assinala que as uniões matrimoniais dos cristãos-novos com nobres cristãos-velhos eram formas de ascensão social e muitas vezes feita de forma estratégica. Florbela Veiga Frade, As relações econômicas e sociais das comunidades sefarditas portuguesas: O trato e a Família -1532-1632; As relações econômicas e sociais das comunidades sefarditas portuguesas: O Trato e a Família -15321632...op. cit., p. 325-329.

${ }^{78}$ Florbela Veiga Frade, As relações econômicas e sociais das comunidades sefarditas Portuguesas: o trato e a família-1532-1632, op. cit, p. 362.
} 
extrapolavam as esferas da família e da etnicidade foram fator decisivo na expansão desse comércio atlântico moderno.

$\mathrm{Na}$ metade do século XVI, e nas décadas seguintes, a pimenta e o comércio do Oriente enriqueciam famílias e clãs sefarditas, como o açúcar que despontava e se expandia na colônia do Brasil, abrindo espaço para o tráfico negreiro, aumentando a abrangência das redes e sua composição e complexidade, momento no qual as redes iam se consolidando. Dessa forma, era necessário que os postos relativos ao trato ficassem restritos à família e ao grupo étnico, o que contribuiu de forma significativa para o fortalecimento e a expansão do comércio no período no qual se deu a virada para o Atlântico.

Nossa premissa é de que as redes não eram fechadas e coesas, mas interligavam-se grandes, pequenas e médias teias familiares, muitas vezes umas crescendo rapidamente, enquanto outras que se dissolviam. Agiam de forma independente, criavam elos e alianças entre seus membros com o objetivo maior de aumentar o capital, o crédito e o poder, ${ }^{79}$ em uma sociedade com valores com fortes resquícios estamentais, na qual, no topo da pirâmide social estavam os nobres e a realeza.

Aos poucos, as redes de comércio comandadas por cristãos-novos foram se organizando de forma mais "racional", procurando a maior eficiência nos negócios. A prosperidade adveio primeiramente das exportações e importações de especiarias, madeiras para tinturaria, pedras, metais preciosos para a cunhagem de moedas. Em pouco tempo, deixaram de ser apenas comerciantes para tornarem-se também financistas. As redes familiares e parentais direcionavam-se para uma maior diversificação, incluindo

\footnotetext{
79 Antonio Borges Coelho. Política Dinheiro e Fé: Cristãos-novos e judeus portugueses no tempo dos Filipes. Cadernos de Estudos Serfaditas. no 1. Lisboa. Cátedra de Estudos Alberto Benveniste, Faculdade de Letras da Universidade de Lisboa, 2000, p. 110.
} 
armazenagem e remuneração do capital via empréstimos, o pagamento de juros e de especulação financeira. ${ }^{80}$ É inegável que as redes sefarditas com base em parentesco foram muito importantes para o sucesso comercial dos comerciantes cristãos-novos, estabelecidos em locais estratégicos de onde efetuavam seus negócios. ${ }^{81}$

O fortalecimento delas decorria da melhor e maior estruturação do comércio ultramarino português, e também da ineficiência do controle fiscal da Coroa que apresentava cada vez mais falhas na arrecadação. A voracidade em busca de receitas, na maioria das vezes de forma extorsiva, prejudicava suas relações com os grupos mercantis de grosso trato, nacionais e estrangeiros. As despesas militares em manter o controle do Índico, o patrulhamento das costas africanas e mesmo as com expedições, tropas e material para rechaçar ameaças estrangeiras às suas possessões ultramarinas consumiam grande parte do erário real. Junto a isso, a manutenção da corte, dos privilégios dos nobres e da realeza debilitavam cada vez mais as finanças régias. Diante das dificuldades, os reis recorriam aos banqueiros e grandes mercadores. Desse modo, o capital econômico nas mãos de grupos de comerciantes de grosso trato com proximidade ao rei era transformado em capital social, visto os banqueiros escolhidos pelos Habsburgos e por D. João VI estarem os negociantes mais opulentos. ${ }^{82} \mathrm{Na}$ realidade essas redes mercantis "eram muito

\footnotetext{
${ }^{80}$ António de Vasconcelos Nogueira. The Portuguese Jews and modern capitalism: trading, insurance, banking, business, and economic thought in Amsterdam from earlier 16th to the first decades of 20th centuries. Portugal: Universidade de Aveiro, 2000. Disponível em: <http://.egi.ua.pt/XXIIaphes/Artigos/ a\%20Nogueira>. Acesso em: 24 abr. 2013.

81 Jonathan. I. Israel. The Dutch Jewry, op.cit, p. 239.

82 “(...) uma estratificação interna do grupo dos comerciantes do grosso trato, decorrente da aproximação de certos segmentos aos círculos do rei. Insiste-se na importância do capital econômico que detinham para o transformar em capital social, pois tanto os Habsburgo como D. João IV recrutaram os seus banqueiros entre os negociantes mais opulentos." Leonor Freire Costa. Império e Grupos Mercantis. Entre o Oriente e o Atlântico (século XVII). Lisboa: Livros Horizonte, 2002, p. 67.
} 
úteis para os reis da Dinastia de Avis e, depois para os Habsburgos de Espanha e Portugal". ${ }^{83}$

A incorporação do Reino de Portugal, em 1580, à Coroa dos Habsburgo espanhóis abriu aos comerciantes de grosso trato novos mercados, mormente o da prata espanhola, via arrematação do contrato de escravos africanos. Os grupos econômicos mais importantes no comércio europeu de origem lusa eram os Ximenes de Aragão, com presença forte em Lisboa, Antuérpia e Amsterdã, contratadores do comércio de Angola desde 1582 até 1619, como também com outros lugares do norte da Europa, os Rodrigues d'Évora, ${ }^{84}$ com o monopólio da pólvora e grandes exportadores para os Países-Baixos, tendo lá se fixado os irmãos Simão e Nicolau, ${ }^{85}$ os Mendes $^{86}$ com diversos grupos econômicos intracontinentais para explorar especiarias, pau-brasil, entre outras mercadorias, na Ásia, África e Brasil, os Lopes Pinto. Esses homens de negócio e de cultura, quase todos de origem judaica, formavam uma elite. ${ }^{87}$

Presentes na Ásia, na África e na América, o pequeno grupo de famílias cristãs-novas que geria os circuitos interligados da prata, dos escravos

${ }^{83}$ José Gentil da Silva. O eixo econômico Lisboa-Antuérpia. Anais da exposição Portugal e Flandres, visões da Europa (1550-1680). Lisboa: Instituto Português do Patrimônio Cultural Mosteiro dos Jerônimos, abr.- maio, 1992, p.2.

${ }^{84}$ A família Veiga ou Vega originou-se no final do século XV, vinda da Espanha. Em 1595, os negócios da família enriquecida estavam nas mãos de quatro irmãos, Simão, Nicolau, Lopo Rodrigues e Rodrigo Lopes de Évora. Os dois primeiros estabeleceram-se em Antuérpia, onde criaram um verdadeiro império comercial, sendo Simão o mentor e o principal dirigente dos grandes tratos familiares. Manuel da Veiga, filho de Rodrigo Lopes. A família espalhou-se por outras praças europeias, como Londres e Amsterdã. As relações com os Ximenes de Aragão (A flor dos contratadores, segundo Manuel), de Antuérpia, eram bastante próximas em termos de amizade, bem como em termos comerciais, já que faziam negócios com seus parentes em Florença e Veneza. Além disso, eles tinham interesses em comum no contrato da pimenta de 1593, sucedendo aos Fugger. A união comercial e também pelo casamento dessas duas famílias ampliou enormemente a influência e ação portuguesa na Europa dos fins do século XVI. J. Gentil da Silva. Stratégies des affaires em Lisboa entre 1595 a 1607. Paris: Armand Colin, 1956, p.1-5.

85 José Gonçalves Salvador. Os Cristãos-novos e o Comércio do Atlântico Meridional. São Paulo: Pioneira, 1978. p. 21-22,

${ }^{86}$ José Antonio Gonsalves de Mello, op. cit. p.4.

${ }^{87}$ José Gentil da Silva. O eixo econômico Lisboa-Antuérpia. Anais da exposição Portugal e Flandres, visões da Europa (1550-1680). ... p.2. 
africanos e das fazendas asiáticas tornou-se a primeira rede mundial de negociantes da história. ${ }^{88} \mathrm{~A}$ família Dias de Milão pertencia era ligada por laços de parentescos aos Ximenes de Aragão e aos Rodrigues d'Evora.

À medida que Amsterdã passou a ser o polo econômico da Europa, responsável pela dinâmica e o ritmo da economia mundial, e cristãos-novos e judeus portugueses solidamente capitalizados foram se fixando na cidade, ampliando o espectro de seus negócios, também foram ampliando a presença de agentes e correspondentes em praças do norte da Europa.

\subsection{Os judeus e cristãos-novos em Portugal}

Nos séculos $\mathrm{XV}$ e $\mathrm{XVI}$, a sociedade e a economia rural européia perdiam importância para as zonas urbanas em desenvolvimento e às atividades pertinentes a elas. As comunidades judaicas que tinham se mantido ativas comercialmente no medievo, tiveram ampla participação nesse momento de reorganização econômica e de ampliação dos espaços de atuação trazida pela economia mercantil transcontinental. Ao longo do século $\mathrm{XV}$, os judeus gradativamente passaram a dominar o exercício das atividades artesanais e do comércio no reino português. Ao mesmo tempo, estavam engajados no comércio marítimo no comércio da especiaria, desde o início das operações comerciais na costa africana, e na exportação para França e Inglaterra de sal, frutos secos, peixe e cortiça em troca de pimenta, incenso, veludos e outras

\footnotetext{
${ }^{88}$ Edval de Souza Barros. Redes de clientela, funcionários régios e apropriação de renda no império português (séculos XVI-XVIII). Revista de Sociologia e Política. Curitiba, nov., 2001, $\mathrm{n}^{\mathrm{o}} .17,127-146$.
} 
mercadorias do Oriente. ${ }^{89}$ Em 1440 contribuíram em termos financeiros para uma expedição às Canárias. ${ }^{90}$ No último quartel da centúria, com a ocupação e exploração das ilhas insulares para lá direcionam parte de seus cabedais, associados a mercadores italianos. Em fins do século XV, controlavam o tráfico negreiro na costa africana. Entre 1491 e 1495, este negócio esteve na mão do judeu italiano Bartolomeu Marchione; entre 1500 e 1505, o tráfico esteve nas mãos de João Rodrigues Mascarenhas, rico mercador judeu de Lisboa e cobrador de diversos impostos, como a sisa e o do pescado. ${ }^{91}$

Os judeus tinham grande importância na economia do reino português, e seus contatos com comunidades hebreias nas cidades italianas, em Antuérpia e no Oriente dinamizavam seus negócios. Em 1473, por autorização de D. Afonso V, os judeus nascidos no Reino a participar da tripulação dos navios que iam ao Atlântico e à África e carregá-los. D. Manuel e D. João III se apoiaram nas comunidades judaicas para o refinanciamento das empresas reais. ${ }^{92}$

Em Portugal os cristãos-novos ou conversos remontam a 1492, no momento em que os reis católicos da Espanha, Fernando de Aragão e Isabel de Castela, expulsaram os judeus de seu território por motivos religiosos, acusando-os de serem hereges. Grande parte dos judeus seguiu para Portugal, enquanto outros seguiram para o Oriente, norte da África e outras regiões da

${ }^{89}$ ANTT. Chancelaria de D. Afonso V, liv. 2., fl. 102. Apud: A. A. Marques de Almeida. Mercadores Cristãos-novos no Negócio da Especiaria (entre 1480 e 1530). Lisboa: Cátedra de Estudos Sefarditas Alberto Benveniste, s/d.

${ }^{90}$ Antonio Barros Bastos. Os judeus no velho Porto. Revista de Estudos Judaicos, p. 73.

${ }^{91}$ José Gonçalves Salvador. Os Magnatas do Tráfico Negreiro, op. cit., p. 129.

${ }^{92}$ Henrique Barros Gama. História da administração pública em Portugal. Lisboa: Sá da Costa, 1945, p. 325. Apud. José Gonçalves Salvador. Os Cristãos-novos e o Comércio no Atlântico Meridional. São Paulo: Pioneira; Brasília: INL, 1978, p. 7. 
Europa. ${ }^{93}$ Os emigrados que seguiam a fé hebreia dedicavam-se ao comércio, ofícios especializados, tais como sapateiros, ourives, alfaiates, navegadores, mercadores de expressão e cargos do serviço público, como médicos na Corte. ${ }^{94} \mathrm{O}$ êxodo forçado atingiu as famílias judias abastadas que na fuga conseguiram trazer os seus recursos e bens de valor.

Em dezembro 1496, o rei D. Manuel III, na tentativa de unir os reinos de Portugal e Espanha pelo seu casamento com a herdeira de Castela, foi obrigado a ceder à imposição espanhola de expulsar os judeus de Portugal para a concretização das núpcias. No final de 1496, o rei assinou o édito de expulsão que dava 10 meses aos judeus e mouros para que deixassem 0 Reino. Os que não emigraram, no início de 1497, foram batizados à força, sob pena de morte, tornando-se obrigatoriamente cristãos-novos. ${ }^{95}$ Dessa forma, impedia-se o êxodo de uma parcela atuante e essencial para o funcionamento da economia lusa. Por esse ato arbitrário, deixaram de existir judeus no Reino - ao menos formalmente -, preservando-se, assim, comerciantes e financistas que ascendiam rapidamente em termos econômicos em Portugal. Em seguida, medidas régias proibiram os cristãos-novos de formar consórcios, como uma forma de incentivar o casamento entre os recém-conversos e cristãos-velhos, e de impedir a saída deles do Reino, sob pena de perda de todos os bens móveis e de raiz para a Coroa.

A falta da liberdade religiosa e a imposição da fé cristã não resultaram na efetiva cristianização da comunidade judaica e nem na sua integração na

\footnotetext{
${ }^{93}$ Keila Grinberg. Inquisição, judeus e cristãos-novos no Brasil, In: Os judeus no Brasil. Keila Grinberg (org.). Rio de Janeiro: Civilização Brasileira, 2005, p. 28.

${ }^{94}$ Angus Maddison. The World Economy: a Millennial Perspective. Paris: OCDE, 2001, p. 1725.

${ }^{95}$ Os muçulmanos também foram convertidos, como lembra Fernanda Olival. Porém, os judeus eram numericamente muito superiores aos muçulmanos que havia em Portugal. Isso explica porque esse termo é associado somente aos judeus conversos. Fernanda Olival. Caderno de Estudos Sefarditas.
} 
sociedade lusa, como o pretendido pelo rei D. Manuel. ${ }^{96}$ Muitos mantiveram secretamente a sua religião e procuravam o hermetismo como forma de manterem suas origens, com a prática de sua religião e ritos, apesar de proibidos e eram chamados de criptojudeus. ${ }^{97}$

Em 1536, foi instituída a Inquisição em Portugal, o Tribunal do Santo Ofício, um tribunal de fé instituído pela Igreja Católica, com poderes delegados pelo papa, que se concentrou a sua ação persecutória nos cristãos-novos, visto que a maior parte das acusações constantes nos processos dos Tribunais portugueses era de judeu e judaizante. $^{98}$

A violência da Inquisição que prendia e instaurava um processo sem que o réu sequer soubesse quais eram as acusações contra ele, além dos métodos utilizados, como o tormento, para obter confissões das culpas; o confisco de bens, o degredo eram ameaças reais, amedrontadoras à integridade física, à família, aos negócios dos cristãos-novos. Diante disso, muitos cristãos-novos procuraram refúgio em outros locais fora de Portugal, fugindo das garras da Inquisição.

Alguns sefarditas fugiram devido à combinação de pressão inquisitorial e a busca por maior liberdade religiosa. Seja qual for o motivo para a emigração desses comerciantes e a formação de sua diáspora, porém, as oportunidades econômicas quase sempre tiveram um papel importante na decisão sobre onde se instalar. op. cit, p. 28-29

${ }^{96}$ Keila Grinberg. Inquisição, judeus e cristãos-novos no Brasil. In: Os Judeus no Brasil. Keila

${ }^{97}$ Maria José Ferro Tavares. A questão judaica. História de Portugal: judaísmo, inquisição e sebastianismo. Barcelona. EDICLUBE, 1993, v. 4, p. 54.

98 Antonio Borges Coelho. Política, Dinheiro e Fé: cristãos-novos e judeus no tempo dos Filipes, op. cit, p. 102. 
A mobilidade dos mercadores sefarditas Ihes concedera uma posição altamente estratégica e, na dispersão, os emigrantes portugueses valeram-se disso ao buscar locais onde se fixar. ${ }^{99}$ Traziam consigo, na "convulsão" provocada pelas rotas de longa distância, conhecimentos essenciais sobre as novas técnicas bancárias e de crédito, praticamente desconhecidas pela fidalguia, como também contatos com as mais importantes praças nos continentes então conhecidos. Essas especificidades Ihes permitiam ascender em termos financeiros e sociais nos locais onde se fixavam, onde a maioria residente era carente de conhecimentos que eles detinham. ${ }^{100}$

Os judeus e cristãos-novos deixaram Portugal e se deslocaram para as praças onde os negócios eram mais rentáveis e atraentes, assim, muitas vezes a diáspora quase pode ser identificada com os circuitos monetários e as praças de câmbios europeias. O espaço da diáspora e dos circuitos monetários não determinou o outro, mas há pontos em comum e diversas vezes foram decisivoas na direção da diáspora. ${ }^{101}$

A Inquisição centrou sua ação nos "crimes" de judaísmo, perseguindo cristãos-novos e criptojudeus, aqueles que mantiveram a fé hebreia secretamente depois da conversão forçada ao catolicismo em 1497. Essa perseguição estendeu-se aos centros dinâmicos do Império Português. Da mesma forma, Jessica Vance Roitman aborda a "Diáspora Ocidental", na segunda parte do século XVI, quando os cristãos-novos fugiram devido à pressão exercida pelo Santo Ofício, o desejo de liberdade religiosa e também

\footnotetext{
${ }^{99} \mathrm{Idem}$.

${ }^{100}$ Nathan Wachtel. La Foi du Souvenir Labyrinthes Marranes. Nuevo Mundo Mundos Nuevos, Número 2 - 2002, mis en ligne le 9 février 2005, référence du 20 août 2013, disponible sur: http://nuevomundo.revues.org/document551.html.

${ }^{101}$ A.A. Marques de Almeida. O Zangão e o Mel. Uma metáfora sobre a diáspora serfadita e a formação das elites financeiras na Europa (séculos XV a XVII). Lisboa, Oceanos, n.26, jan.-mar., 1997, p. 32 .
} 
em busca de oportunidades econômicas. ${ }^{102}$ No século XVII, a pressão inquisitorial aumentou bastante e a emigração também, o que paralelamente coincidiu com a expansão econômica no norte da Europa, América e Índias Orientais e Ocidentais. ${ }^{103}$

Christopher Ebert afirma que, sem dúvida, a dispersão geográfica dos cristãos-novos os colocou numa posição vantajosa nos novos circuitos comerciais, embora isso não necessariamente esteja atrelado a redes étnicas ou culturais. Ernst Pinjing voltou-se para a colônia do Brasil, no Nordeste açucareiro, com a vinda de cristãos-novos como empreendedores desse negócio no século XVI, como senhores de engenho. Para ele, esse deslocamento colocava-se como possibilidade de ascensão social, visto que atingiam o topo da hierarquia social em solo colonial. ${ }^{104}$

A diáspora não deve ser entendida apenas como a vontade de viver livremente a fé dos judeus que continuaram com suas crenças mesmo depois da conversão forçada em cristão-novos, embora muitos tenham deixado 0 Reino para poder viver abertamente sua identidade judaica. É inegável que o Tribunal do Santo Ofício português amendrontava os criptojudeus e cristãonovos que temiam por suas vidas e pelo confisco de seus bens. Porém, os dois primeiros fatores juntaram-se a interesses econômicos em um mundo em plena expansão mercantil que oferecia da Índia à América a possibiidade de enriquecimento e maior tolerância religiosa. Os cabedais, a maior capacidade intelectual dada pelos estudos e a longa atividade na mercâncias dos serfaditas

\footnotetext{
102 Jessica Vance Roitman. The Same but Diferent?:Inter-cultural Trade and the Serphadim 1595-1640, op.cit. p. 81.

103 Yosef Kaplan. The Formation of the Sephardic Diaspora. 136-155. Apud: Jessica Vance Roitman. The Same but Different?, op cit, p. 81.

${ }^{104}$ Ernst Pinjing. New Christians as Sugar Cultivators. In: Paolo Bernardini; Norman Fiering (Edited). The Jews and the Expansion of Europe to the West 1450- 1800. The John Carter Brown Library, 2001, p. 486.
} 
fizeram com que corressem o mundo e se tornassem senhores do comércio internacional e das finanças.

\subsection{A diáspora cristã-nova e as novas possibilidades}

\section{econômicas}

Muitos cristãos-novos fugiram de perseguições do Santo Ofício e começaram por se estabelecer em comunidades da diáspora em Flandres, França, Itália, Turquia, Índia e no norte da África. ${ }^{105}$ A procura por novos centros econômicos esteve integrada à própria dispersão das famílias com intensa atividade no trato, com ramificações em todos os continentes.

Os que deixavam o Reino optavam por locais onde iriam encontrar comunidades instaladas por pessoas que professavam a sua religião, 0 judaísmo. Muitos emigrantes eram profissionais da medicina, ciência, direito, e letras, mercadores e homens de negócio, que dispunham frequentemente de meios financeiros que Ihes permitiam efetuar investimentos imediatos, profissionais e comerciais nos locais onde se instalavam. ${ }^{106}$

Embora a diáspora tenha se dado pela Europa e áreas do Império Otomano, foi sem dúvida, Antuérpia e Amsterdã que receberam a maior parte dos conversos ou cristãos-novos que deixaram Portugal e se estabeleceram nos Países Baixos. ${ }^{107} \mathrm{Na}$ realidade, a diáspora se deu por vários pontos da Europa, norte da África e Ásia. Vejamos alguns deles.

105 A. J. R. Russel-Wood. Fluxos de emigração. In: (dir.) Francisco Bethencourt, Kirti Chaudhuri. História da Expansão Portuguesa. A formação do Império (1415-1570). Navarra; Círculo de Editores, 1998, v.1, p. 226.

${ }^{106}$ Idem, ibidem, p. 234.

${ }^{107}$ Jessica Vance Roitman, op. cit. p. 82. 


\subsubsection{Antuérpia}

Antuérpia já realizava feiras de comércio no final do século $X V$ e foi escolhida, em 1498, para sediar uma feitoria portuguesa que garantisse a distribuição e abastecimento do norte da Europa, centro estratégico para as áreas circundantes e próximas dos mares do Norte e Báltico dos produtos do monopólio real colonial. ${ }^{108}$ Também aí se instalou uma expressiva colônia mercantil espanhola, passando os negócios das coroas ibéricas a serem realizados majoritariamente na cidade. Ao longo do século XVI, Antuérpia tornou-se o centro econômico mais importante do continente. Uma numerosa colônia de comerciantes flamengos fixou-se em Lisboa para vitalizar o trato. Após 1545 o afluxo de portugueses cristãos-novos em Antuérpia, o polo econômico mais dinâmico da Europa, foi significativo, onde não havia perseguição religiosa e havia muitas oportunidades de negócio, ${ }^{109}$ e com custo de vida mais barato que em Portugal. ${ }^{110}$ Por volta de 1570, havia cerca de 400 cristãos-novos de origem portuguesa vivendo na cidade. ${ }^{111}$

Nas primeiras décadas do século XVI, os irmãos Mendes, cristãos-novos de Lisboa, se tornaram grandes financistas e banqueiros, além de grandes comerciantes ligados ao negócio da prata, da pimenta e das pedras preciosas

\footnotetext{
${ }^{108}$ Antuérpia desenvolveu-se não só com a distribuição das especiarias, óleo, frutas, entre outras mercadorias portuguesas. O comércio do sal elevou ainda mais Antuérpia como centro distribuidor, agora não só mais português, tornando-a um grande depósito de mercadorias a serem distribuídas na Europa. A partir de 1525 , as casas de comércio passaram a trabalhar também com finanças, tornando-se centro financeiro, praça de câmbio vital entre regiões européias, sendo o câmbio (e o recâmbio, com juros) que alimentava as estruturas sociais. José Gentil da Silva. O eixo econômico Lisboa-Antuérpia. Anais da exposição Portugal e Flandres, visões da Europa (1550-1680). Lisboa: Instituto Português do Patrimônio Cultural Mosteiro dos Jerónimos, abr.-maio 1992, p. 2.

109 Florbela Veiga Frade. As relações econômicas e sociais das comunidades sefarditas portuguesas: o trato e a família-1532-1632.... op.cit. p. 177-179; Maria José Ferro Tavares. A questão judaica. In: História de Portugal. Judaísmo, Inquisição e Sebastianismo Vol. IV. Barcelona: Ediclube, 1993. p. 61.

${ }^{110}$ Idem.

${ }^{111}$ Jessica Vance Roitman, op. cit. p. 83.
} 
que foram montaram seus negócios em Antuérpia. Diogo Mendes transferiu-se para Antuérpia, onde se dedicava às finanças e ao negócio da pimenta, ficando Francisco Mendes em Lisboa, cuidando dos interesses da família como se pode provar pelas mais de duas toneladas e meia de prata que entregou na Casa da Moeda entre 1517 e $1534 .{ }^{112}$

$\mathrm{Na}$ segunda metade do século $\mathrm{XVI}$, o açúcar do Brasil dava nova dinâmica ao comércio internacional, continuando Portugal a ser o epicentro receptor da produção agrícola colonial e do comércio do Oriente, enquanto a Espanha sorvia a prata americana.

A guerra espanhola na região dos Países-Baixos para conter a revolta de Flandres contra a Coroa filipina e o cerco e isolamento de Antuérpia, em 1569, fecharam o comércio luso com esse importante entreposto comercial do norte da Europa. Essa praça era essencial para as trocas com o Noroeste do continente. Os lusos vendiam especiarias, frutas, vinho, azeite e compravam roupas, metais, madeiras e cereais. ${ }^{113} \mathrm{O}$ sal era um dos mais importantes produtos trocados com o norte da Europa, que saia basicamente do Porto e de Viana. ${ }^{114}$

\subsubsection{Amsterdã}

Em virtude dos conflitos militares em Flandres, e da reconquista da cidade pelos espanhóis em 1585, houve forte emigração de cabedais e comerciantes (e seus contatos) para Amsterdã, que se tornou a mais importante praça mercantil do continente. As oportunidades com base no

${ }^{112}$ A. A. Marques de Almeida, Capitais e capitalistas, p. 33-36.

${ }^{113}$ Francisco Bethencourt. Os limites da expansão asiática, op. cit., p. 10-11.

${ }^{114}$ Amândio Barros. Os Portugueses no Porto, op.cit. p. 365. 
comércio colonial continuavam atraentes, como tinham sido para o curso do século XVI, em Antuérpia. Mais importante, porém, Amsterdã e Hamburgo tornaram-se entrepostos coloniais, fato que, sem dúvida, desempenhou um papel importante na escolha dos mercadores sefarditas para lá se estabelecerem. Porém, no final do dezesseis uma nova leva de cristãos-novos que tinham feito fortuna com o açúcar brasileiro, como mercadores e/ou senhores de engenho deslocaram-se para Amsterdã, onde muitos deles assumiram a religião judaica, adotando nomes judeus, formando a "Nação Portuguesa". ${ }^{115}$ Mercadores de grosso-trato, com interesses e negócios em todos os continentes podiam ser, em sua grande maioria ser classificados como globais players, na definição de Cátia Antunes. ${ }^{116}$

A cidade holandesa, além disso, tinha destaque na manufatura, na confecção têxtil, na construção de embarcações e como centro financeiro em expansão. A tolerância religiosa permitida pelas autoridades de Amsterdã aos migrantes, particularmente aos judeus que tinham liberdade de culto, encontra respaldo em motivos econômicos: sabia-se que os judeus eram mercadores de longa data, dominando as habilidades desse negócio. Tinham grande conhecimento dos mercados estrangeiros, mantinham fortes conexões com o trato internacional e tinham cabedais que certamente seriam transferidos para a cidade. Em 1577, os irmãos Pieter e Jasper de Morimont, estabelecidos em Antuérpia, pediram ao governo da cidade de Leiden para estabelecer ali uma refinaria de açúcar. Em Amsterdã, a primeira menção a esse tipo de

115 O termo Nação Portuguesa nos documentos da StudiaRosenthaliana, registros dos cartórios notariais de Amsterdã, é recorrente o uso desse termo para designar os comerciantes judeus portugueses moradores em Amsterdã.

116 Cátia Antunes. Globalization in the Early Modern Period: The economic relationship between Amsterdam and Lisbon, 1640-1705, op.cit, p. 89-96. 
estabelecimento de refino data de 1597. Em 1605 havia três refinarias funcionando na cidade. Em 1650 esse número pulou para quarenta. ${ }^{117}$

A partir da década de 1590, cristãos-novos portugueses, com seus capitais e sua experiência mercantil e financeira estabeleceram-se em Amsterdã. As mesmas conexões estabelecidas anteriormente em Antuérpia continuaram a ser feitas pelos mesmos cristãos-novos, muitos deles agora judaizados. De lá mantinham conexões com Livorno e Veneza e com outras ramificações da diáspora sefardita que seguiu para o Oriente, a costa Dálmata, Salônica e Constantinopla. ${ }^{118}$

Os primeiros que seguiram foram os da família Duarte Saraiva e Lopes Homem. Em 1596, Manuel Rodrigues Veiga, morador de Lisboa e membro da poderosa família de mercadores e financistas Veiga, de Lisboa, um dos expoentes dos cristãos-novos (judeus em Amsterdã) mercadores de açúcar, mantinha dois grandes depósitos na cidade. Um deles era usado para armazenar açúcar que ele recebia da llha de São Miguel, no Atlântico. Além disso, ele manifestou intenção de estabelecer uma manufatura da seda. $O$ negócio da seda era muito rentável e em meados do século XVI, Josef Nassi, primo dos Mendes, banqueiros de Antuérpia, tentou conseguir autorização para estabelecer uma colônia de produção de seda na Palestina, visando alimentar o comércio europeu com esse fino tecido. Em 1604, Manuel Rodrigues da Veiga propôs ao burgomestre de Amsterdã a instalação de uma manufatura de seda na cidade. O Conselho de Amsterdã deu autorização para o português Emanuel Rodrigos operar as duas manufaturas de seda. No ano seguinte,

${ }^{117}$ Herbert I. Bloom. The Economic Activities of the Jews in Amsterdam in the Seventeenth and Eighteenth Centuries. London: Kennikat Press, 1969, p. 37-38.

${ }^{118}$ Idem, ibidem, p. 34-35. 
Estevão Cardoso, ligado também ao negócio do açúcar no Brasil e em Portugal, conseguiu autorização para operar mais duas manufaturas de seda. ${ }^{119}$ Desse modo, floresceu, com matéria-prima chinesa, uma expressiva indústria de seda em Amsterdã.

A comunidade judaica de origem portuguesa em Amsterdã teve participação ativa na nascente indústria e no desenvolvimento das manufaturas. ${ }^{120}$ Capitais oriundos de Portugal e Espanha foram transferidos para lá com medo do confisco inquisitorial por parte dos cristãos-novos, mesmo de muitos que permaneceram em Lisboa ou Sevilha. ${ }^{121}$ Além disso, Amsterdã tornou-se um polo de conhecimento em relação às viagens transoceânicas, dado o conhecimento náutico e cartográfico que lá se acumulava. O mais importante centro comercial da Europa, onde se negociavam os contratos de frete e seguros de cargas dos navios, aquisição e ampliação de crédito, a troca de informações entre os comerciantes, a internacionalização dos comerciantes e agentes baseados em Amsterdã permitiu uma intensa troca de informações e estes acabaram sendo privilegiados sobre os concorrentes em outras praças. Dessa forma, expandiu-se a necessidade de serviços acessórios ao comércio como corretagem e seguros. Em 1609, foi criado o Exchange Bank com o intuito de coordenar o câmbio e permitiu centralizar as transações com as letras de câmbio (e as políticas de juros) que muito contribuiu para a expansão do transporte e do comércio. Com o crescimento de Amsterdã, o comércio deixou de ser sazonal, como em Bruges e em Antuérpia, estando presente o

119. Nathan Wachtel. La Foi du Souvenir Labyrinthes Marranes. Nuevo Mundo Mundos Nuevos, Número 2 - 2002, disponible sur: http://nuevomundo.revues.org/document551.html Nathan Wachtel, «La Foi du Souvenir Labyrinthes Marranes », Nuevo Mundo Mundos Nuevos, Debates, 2005, [En línea], Puesto en línea el 9 febrero 2005. URL: http://nuevomundo.revues.org/551. Consultado el 31 agosto 2013.

${ }^{120}$ Marcus Arkin. Aspects of Jewish Economic History. New York: Jewish Publication Society of America, 1975, p. 90.

${ }^{121}$ Jonathan Irving Israel. Dutch Primacy in World Trade 1585-1740, op. cit, p. 128-136. 
ano todo, atraindo corretores, agentes e mercadores de menor porte e outras formas de associações e esquemas de participação acionária com interesse no comércio de longa distância.

Em 1612, contabilizava-se a presença de cerca de 500 sefarditas em Amsterdã e um número menor de cristãos-novos e judeus assumidos viviam em como Roterdã e Middelburg, e os registros mostram que grande migração ocorreu para Roterdã durante a Trégua dos 12 anos entre Espanha e Holanda (1608-1620). Com o fim da trégua, a migração para Amsterdã voltou a crescer significativamente.

O número destes emigrados variou, mas a migração nunca deixou de crescer no decorrer do século XVII. Dos 500 sefarditas em Amsterdã registrados em 1612, o número havia pulado 1000 em 1620. Em 1672, estimase que totalizassem 2500.

\subsubsection{Os territórios alemães}

Com a queda de Antuérpia, além de Amsterdã, cristãos-novos e judeus portugueses e migraram para o noroeste da Alemanha, em especial, mercadores de grosso trato com conexões transcontinentais. Hamburgo era o maior centro no comércio de açúcar, especiarias, fumo, algodão e outros produtos coloniais. ${ }^{122}$ Havia uma intensa conexão entre Amsterdã e Hamburgo em termos comerciais e financeiros. Proeminentes comerciantes sefarditas em Amsterdã e seus correspondentes, não raro, enviavam pau-brasil e açúcar por

\footnotetext{
${ }^{122}$ Jessica Vance Roitman, op. cit., p. 88-89.
} 
Hamburgo, ${ }^{123}$ como também havia intenso tráfego marítimo entre Hamburgo e os portos ibéricos. A carta patente concedida em 1612 deu a primeira aprovação oficial para que os judeus vivessem como tal em Hamburgo, embora seu direito de viver abertamente como judeus sua fé tenha sido limitada, pois eram proibidos de praticar publicamente os rituais dentro dos da cidade. A ida dos judeus e cristãos para Hamburgo é simultânea com a para a Amsterdã, dando-se a partir de 1600.

Da mesma forma, quando a trégua terminou em 1621, ocorreu um movimento inverso em direção a Hamburgo, visto poderem continuar com as transações mercantis com a Península Ibérica sem qualquer tipo de restrição.

Em 1605, um dos primeiros cristãos-novos a se estabelecer em Hamburgo foi Álvaro Dinis (Samuel Jachia) que havia morado em Pernambuco, ligado ao açúcar, além de Antuérpia, Veneza e Salônica. Em 1606, casou-se com a filha de Henrique Dias de Milão, Beatriz Henriques, que veio de Portugal para se casar em Hamburgo. ${ }^{124}$ Tornou-se distribuidor de açúcar e sal, exportador e importador de grãos em Hamburgo, Glueckstadt, Lubeck, Gdansk/Danzig. ${ }^{125}$

\subsubsection{Espanha}

As políticas espanholas exerceram uma poderosa influência sobre os sefarditas em Amsterdã. O Império espanhol controlava politicamente os Países Baixos espanhóis (Antuérpia), Portugal, Brasil, América espanhola, e

${ }^{123}$ Manoel Rodrigues Vega. Studia Rosentahliana 98.

${ }^{124}$ ANTT. Inquisição de Lisboa, Processo 6677.

125 Florbela Veiga Frade. Anais de História de Além-Mar. Pensamento religioso dos judeus portugueses de Hamburgo no século XVII. Merkabah, apegamento a Deus e o Tabernáculo em Trinta Discursos ou Darazes (Hamburgo, 1629) de Samuel Jachia/Álvaro Dinis (c.1570-1645), 2010, p.181-212. 
grande parte do norte litoral africano onde os sefarditas eram economicamente ativos. Além disso, a própria Espanha era um destino os mercadores sefarditas para o comércio clandestino, ou até mesmo para o comércio legítimo.

Durante a União Ibérica (1580-1640), cristãos-novos fizeram o movimento inverso da expulsão de 1492 pelos reis católicos de muitos de seus antepassados judeus, voltando para a Espanha. Entre as razões estava o fato de que não poderiam ser julgados por crimes cometidos em Portugal ligados à Inquisição, como o de judaizantes. Além disso, as colônias espanholas foram uma opção atraente para muitos sefarditas em termos econômicos, atraídos pela prata e pelas outras atividades que estavam presentes na América espanhola. Enquanto a repressão em Portugal recrudescia nas primeiras décadas do século XVII, ela era mais amena na Espanha, visto que nos últimos anos do século XVI e início do século XVII, na Espanha os processos foram em menor número do que no Reino. ${ }^{126}$

Era proibido aos portugueses fixarem-se na América Espanhola, mas de nada valia a imposição régia, visto que muitos lusos viviam na porção americana administrada pela Espanha. Houve uma forte presença sefardita na Nova Espanha (atual México), assim como no Peru, na região do Rio da Prata da América do Sul (atual Argentina, Paraguai e Uruguai), e Nova Granada (atual Colômbia e Venezuela). O acesso dos cristãos-novos foi de tal ordem que "judeu" e "português" eram praticamente sinônimos.

Assim, muitos cristãos-novos e judeus mudaram-se para Espanha que oferecia aos mercadores convenientes oportunidades de negociar. Os mercadores cristãos-novos formavam um segmento importante do comércio

${ }^{126}$ Egon e Frieda Wolff. Os judeus em Amsterdã. Rio de Janeiro: Instituto Histórico e Geográfico, 1989. p 35. 
com as Índias Ocidentais e eram eles que concediam empréstimos ao rei e tinham o domínio sobre o comércio dos escravos, do dinheiro e do açúcar. ${ }^{127}$

\subsubsection{Inglaterra}

Em 1290, a Inglaterra proibiu a presença de judeus em seu território e os expulsou. Sabe-se, no entanto, que um número pequeno de seguidores da fé hebreia de origem ibérica vivia em Londres desde os finais do século XV. Registros mostram que na diáspora, poucos sefarditas estabeleceram na capital do reino inglês, embora não pudessem externar suas crenças, vivendo, então, como católicos. No início do século XVII, cresceu o número de cristãosnovos que se dirijam para Londres devido a sua crescente importância no comércio internacional. ${ }^{128}$ As estimativas variam, mas houve possivelmente até 50 a 100 sefarditas em Londres antes que fosse readmitida sua presença em território inglês em 1656.

\subsubsection{Brasil}

A intensificação da perseguição, principalmente a partir da segunda metade do século $\mathrm{XVI}$, coincidiu com o desenvolvimento da produção açucareira no Brasil e os primórdios do tráfico negreiro - este, como um dos negócios dos mais rentáveis do período. O horizonte das atividades de trocas e das mercancias abria-se em grande velocidade. A diversificação geográfica dos

${ }^{127}$ António José Saraiva. Inquisição e cristãos-novos. Lisboa: Editorial Estampa, 1985. p. $72-$ 85.

${ }^{128}$ As estimativas variam, mas calcula-se que por volta de 1650 haveria em Londres entre 50 e 100 sefarditas. 
clãs mercantis foi fundamental para a dinamização do processo de acumulação, e que este se desse fora de Portugal.

Abraham Levi nos informa que desde a segunda metade do século XVI, o Brasil foi um receptáculo de sefarditas, e que estes desempenharam um papel fundamental na sustentação e desenvolvimento econômico-comercial das terras brasílicas. ${ }^{129}$ Boyajian afirma que a participação dos cristãos-novos na economia Atlântica foi mais significativa do que se supõe, destacando-se no financiamento da empresa colonial. ${ }^{130}$

Os cristãos-novos destacaram-se nessa empreitada além-mar, como senhores de engenhos e, principalmente, no controle do negócio do açúcar. Fixaram-se principalmente em Pernambuco e em Salvador, Bahia. ${ }^{131}$

A partir dos anos 1570/1580, homens de grandes cabedais e membros dos clãs mercantis de origem sefardita fixaram-se no Brasil organizado em relações familiares. Entre 1587 e 1592, na Bahia, havia cerca de 41 engenhos cujos proprietários tiveram suas origens identificadas, sendo 12 deles cristãosnovos. ${ }^{132}$ Embora se alternassem em posições estratégicas no Brasil, Portugal e África, bases do trato açucareiro e negreiro, mantendo grandes ligações com o Reino, Antuérpia e Amsterdã. ${ }^{133}$ Apesar da Inquisição ser uma ameaça aos cristãos-novos e a saída do reino ser creditada como meio para escapar das

${ }^{129}$ Joseph Abraham Levi. A diáspora sefardita nas Américas durante os séculos XVII e XVIII. Cadernos de Estudos Sefarditas. Lisboa: Cátedra Alberto Benveniste; Universidade de Lisboa, 2002, n. 1, p. 27.

${ }^{130}$ James C Boyajian, Portuguese Bankers, op. cit., p. 83.

${ }^{131}$ Silvia Ricardo. As Redes Mercantis no Final do Século XVI e a Figura do Mercador João Nunes Correia. [Dissertação de Mestrado]. Departamento de História. FFLCH, USP, 2007.

132 Stuart Schwartz. Segredos internos: engenhos e escravos na sociedade colonial 1550- 1835. op. cit. p. $79-80$.

133 Maria Leonor Freire Costa. A Rota do Cabo e as Rotas do Brasil: Para um estudo comparado do transporte marítimo nos Séculos XVI e XVII. Texto apresentado no Seminário O mundo que o português criou: Brasil século XVI. Fundação Joaquim Nabuco: Recife, out. 1997; José Antonio Gonsalves de Mello. Gente da Nação: Cristãos-novos em Pernambuco, 1542-1654. Recife: Fundação Joaquim Nabuco; Massangana, 1996. 
garras do Santo Ofício, grande parte dos cristãos-novos de clãs mercantis de grande projeção em Portugal, efetivamente demoraram-se por anos na Colônia.

A partir de 1570, chegaram ao Nordeste cristãos-novos que se estabeleceram como senhores de engenho na Bahia e em Pernambuco. Ricos mercadores em Portugal, membros da elite serfadita, membros das principais redes de comércios lusas. Suas vindas à Colônia estiveram muito mais ligadas a motivos econômicos do que religiosos. Eram homens de projeção que aqui se fixaram e, não raro, eram substituídos ou mandavam diretamente seus filhos e aparentados para tocar os negócios do açúcar, permanecendo os líderes das casas de comércio em Lisboa e no Porto.

No que diz respeito à elite colonial, que naquele momento significava basicamente os donos de engenhos do Brasil, verificava-se a presença de cristãos novos portugueses de importância em Portugal, como os Fernandes d'Elvas, Évora e Veiga.

Os primeiros cristãos-novos que se estabeleceram em Pernambuco foram Diogo Fernandes, pertencente à família Fernandes Camaragibe do Porto, e Pedro Álvares Madeira, e ambos montaram o Engenho Camaragibe, em Jaboatão. ${ }^{134}$ Expoentes da elite mercantil lusa como João Nunes Correia, ${ }^{135}$ Duarte Dias Henriques Miguel Dias Santiago ${ }^{136}$, James Lopes da Costa, que foi denunciado ao Visitador do Santo Ofício como sendo senhor de engenho na várzea de Capibaribe desde 1580, rico mercador, cristão-novo e onzeneiro

${ }^{134}$ José Antonio Gonsalves de Mello, Gente da Nação: op. cit., p. 27; 35.

${ }^{135}$ João Nunes Correia presume-se tenha chegado ao Brasil for volta de 1580. Além de senhor de engenho na Paraíba com seu irmão Diogo Correa, foi contratador do pau-brasil, estava envolvido no negócio da pimenta e era tido como onzeneiro, pessoa que emprestava dinheiro a juros considerados extorsivos em Pernambuco.

${ }^{136}$ Duarte Dias Henriques foi senhor de engenho, grande comerciante de açúcar e contratador de escravos. 
público, e no início da década seguinte tornou-se rendeiro da cobrança dos dízimos em Pernambuco ${ }^{137}$ entre outros, cruzaram o Atlântico e tornaram-se senhores de engenho que viveram por muitos anos em Pernambuco e tempos depois foram encontrados na Espanha, Amsterdã, Madri.

João Nunes Correa era senhor de dois engenhos na Paraíba, lutou contra a expulsão dos franceses na Paraíba e se tornou um dos mais poderosos homens da colônia, além de contratador de pau-brasil e de escravos, amigo dos mais influentes senhores de engenho e comerciantes de açúcar da época. ${ }^{138}$ Seu sobrinho, João Nunes Saraiva, na década de 1620 , foi um dos financiadores da Coroa espanhola, dono de uma enorme fortuna. ${ }^{139}$

A Visitação do Santo Ofício alcançou o Nordeste do Brasil em 1591, e virou-se, em especial, contra os cristãos-novos, sendo a maioria acusados de judaizantes e de crimes de judaísmo. Henrique Nunes, irmão de João Nunes, estabelecido em Lisboa de onde gerenciava os negócios da família, foi informado da vinda do Visitador-Geral às partes do Brasil e enviou uma carta ao irmão João para que retornasse a Portugal junto com o amigo e contratador de escravos e senhor de engenho, Duarte Dias Henrique, visto que corriam risco com a chegada da Inquisição ao Nordeste brasileiro em 1591. A carta foi entregue ao Governador Geral do Brasil e demorou seis meses para chegar. $\mathrm{O}$ Visitador, porém, veio na mesma embarcação que o governador, chegando à Bahia em 1591, o que impediu a entrega da carta de Henrique. João Nunes

${ }^{137}$ Denunciações de Pernambuco, p. 317, 473. James Lopes da Costa foi um dos primeiros cristãos-novos a emigrar para Amsterdã. Era o senhor do Engenho da Várzea, tendo voltado a Lisboa e de lá, com a família, para Amsterdã, onde se encontrava em 1598, Se assumiu judeu com o nome de Jacob Tirado. Foi um dos fundadores da sinagoga de Amsterdã em 1602.

${ }^{138}$ Silvia C. Ricardo. O Comerciante João Nunes Correa.... op. cit., p. 135-147. 83.

139 James C. Boyajian. Portuguese Bankers and the Court of Spain (1626-1650), op.cit p.19; 78; 
Correa foi acusado de judaísmo e preso, chegando a Lisboa em janeiro de 1592.

O fato de a herança estar vinculada a primogenitura masculina, os demais filhos homens que não pertencessem à nobreza não tinham muitas alternativas econômicas na segunda metade do século XVI e nas primeiras décadas do século XVII. Em virtude disso, os meninos e jovens eram mandados para pontos estratégicos para ajudar nos negócios da família, muitas vezes, como agentes ou mesmo para dar início à atividade de produção de cana de açúcar, comprando ou montando um engenho. ${ }^{140}$ Esse foi o caso de Miguel Dias Santiago que veio ao Brasil com pouca idade e João da Paz, sobrinho também de Miguel Dias Santiago e de Duarte Ximenes, ligado aos ricos Ximenes de Antuérpia que chegou ao Brasil com 10 anos. ${ }^{141}$ Miguel tornou-se senhor de engenho e sua propriedade continuou na família com Bento Dias Santiago. A família Dias de Milão também enviou jovens para que morassem no Brasil, e se dedicassem ao negócio do açúcar. Sabemos que três dos filhos do comerciante de grosso trato Henrique Dias de Milão moraram em Olinda. Os processos inquisitoriais nos informam que dois deles estiveram por muitos anos estabelecidos em Pernambuco: Manuel Cardoso de Milão, que no momento da prisão da família tinha 31 anos, esteve nas partes do Brasil por 14 anos, ${ }^{142}$ Antonio Dias, que tinha 24 anos em 1606, estivera por muitos anos no Brasil $^{143}$ e morava em Pernambuco com seu irmão Manuel. ${ }^{144}$

\footnotetext{
${ }^{140}$ José Antonio Gonçalves de Mello, Gente da Nação, op. cit., p. 38.

${ }^{141}$ José Antonio Gonçalves de Mello, op. cit.; James C. Boyajian. Portuguese Bankers at the Court of Spain (1626-1650), op. cit, 1983.

${ }^{142}$ ANTT. Inquisição de Lisboa, Processo 6677.

${ }^{143}$ ANTT. Inquisição de Lisboa, Processo 2523.

${ }^{144}$ ANTT. Inquisição de Lisboa, Processo 6677.
} 
Manoel Carvalho é um exemplo da presença sefardita na colônia do Brasil com fortes conexões com Amsterdã. Nasceu no Porto em Portugal em 1565, filho de Pero Fernandes e Guiomar Henriques, e passou boa parte de seus primeiros anos no Brasil, onde a família era proprietária de dois engenhos ao longo do rio Camaragibe, em Pernambuco. Carvalho herdou esta propriedade, tornando-se senhor de engenho e membro da elite da sociedade colonial. A propriedade da terra conferia prestígio social e influência política. ${ }^{145}$ Tendo se tornado um grande produtor de açúcar e exportador, e feito grande fortuna, além de pertencer à elite mercantil, ${ }^{146}$ mudou-se para Amsterdã, onde há registros de sua presença nos arquivos notariais em 1602.

É Janaína Guimarães quem melhor caracteriza a ação dos cristãosnovos em Pernambuco no período estudado. Dedicando-se ao estudo dos cristãos-novos na Capitania de Pernambuco, nos informa: "A realidade reinol, contudo, não pode ser transposta para os comerciantes estabelecidos na América portuguesa, e mais especificamente em Pernambuco. Estes últimos envolveram-se em diversas atividades lucrativas na capitania, como o ramo dos transportes marítimos, dos seguros e em cargos administrativos que os fizeram prosperar e manterem-se estabelecidos até ao menos a chegada dos holandeses a Pernambuco., ${ }^{147}$ Em sua tese de doutorado, ${ }^{148}$ observou que dos 165 mercadores cristãos-novos que viviam em Pernambuco, entre os anos de

${ }^{145}$ David Grant Smith; Rae Flory, - Bahian Merchants and Planters in the Seventeenth and Early Eighteenth Centuries, The Hispanic American Historical Review, Vol. 58, No. 4 (Nov., 1978), p. 571-594; 586.

${ }^{146}$ David Grant Smith. The Mercantile Class of Portugal and Brazil in the Seventeenth Century, op. cit. p. 327-336.

${ }^{147}$ Janaina Guimarães da Fonseca e Silva. Comerciantes cristãos-novos: do açúcar ao tráfico de escravos para as Índias de Castela. Disponível em: <http://www.historia.uff.br/7mares/wpcontent/uploads/2014/04/v01n01a11.pdf>. Acesso em: 12 jul. 2014.

148 Janaina Guimarães da Fonseca e Silva. Cristãos-novos nos negócios da Capitania de Pernambuco: relacionamentos, continuidades e rupturas nas redes de comércio entre os anos de 1580 e 1630. [Tese de Doutorado]. UFPE, 2012. 
1580 e 1630, somente sete com negócios na América espanhola lá se estabeleceram. Os demais, ainda que mantivessem negócios com familiares e parentes que lá vivessem, não deixaram Pernambuco ou estavam envolvidos em outras atividades mercantis como o comércio com o Oriente. Para Janaína Guimarães, "o período de união das coroas ibéricas como extremamente próspero tanto para os cristãos-novos estabelecidos na capitania de Pernambuco quanto para os que optaram pelas possessões espanholas na América." ${ }^{149}$

\subsection{A ascensão dos cristãos-novos no comércio e nas finanças europeias}

\subsubsection{A comunidade sefardita}

Quando se pensa na comunidade de mercadores sefarditas portuguesa nos séculos $\mathrm{XVI}$ e XVII precisamos procurar dar seus contornos, para evitar super dimensioná-la, como se fosse muito numerosa. Os estudos demográficos sobre o período são escassos e metodologicamente imprecisos, dada a dificuldade com as fontes. Florbela Veiga Frade, reconhecendo essa dificuldade, se reporta a relatos de época para tentar suprir essa lacuna. Cristovão Rodrigues de Oliveira, entre os anos de 1551-1155 fez um levantamento sobre as profissões dos moradores de Lisboa e chegou à conclusão que havia cinco cambistas; seis mercadores banqueiros; 28 mercadores de seda e 60 de panos com loja; 28 marchantes; 75 almocreves;

${ }^{149}$ Janaina Guimarães da Fonseca e Silva. Comerciantes Cristãos-novos: do açúcar ao tráfico de escravos para as Índias de Castela. Disponível em: <http://www.historia.uff.br/7mares/wpcontent/uploads/2014/04/v01n01a11.pdf>. Acesso em: 12 jul. 2014. 
458 de todo os tipos de mercadorias e 620 tratantes. ${ }^{150}$ Também se reporta a João Brandão que em 1552 relatou haver em Lisboa dez tendas de lapidários, com duas ou três pessoas cada uma, ${ }^{151}$ doze corretores de mercadorias, 150 almocreves e dois corretores de letras de câmbio. ${ }^{152}$

David Grant Smith nos traz dados que demonstram que uma parte da população cristã-nova que, embora pouco significativa numericamente, tinha grande projeção econômica, entre 1620 e 1690, e entre eles havia os de grosso trato e os financistas ou banqueiros, totalizando 150 indivíduos. Esses mercadores chamados mercadores-banqueiros eram $0,5 \%$ do total, e, na melhor das hipóteses, $4 \%$, quando se considera somente os mercadores com alguma relevância de fato. Eram estes que ocupam o topo da hierarquia, composta por uma elite de meia dúzia de famílias que também controlavam o comércio com o Oriente e da pimenta. ${ }^{153} \mathrm{~A}$ importância econômica dessa elite mercantil e financeira foi de tal ordem, que seus capitais financiaram a Coroa em diversos momentos, alguns deles cruciais, quando banqueiros e financistas portugueses socorreram o tesouro real na bancarrota em $1626 .{ }^{154}$

Em 1620, Frei Nicolau de Oliveira apontava a existência de 33 mercadores de seda e 38 de fibras de seda; 36 de roupa; 17 de produtos da Índia; 24 de mercadorias de menor valor, como facas, pregos que eram

150 Florbela Veiga Frade. As relações econômicas e sociais das comunidades sefarditas portuguesas. O trato e a Família -1532-1632, op. cit., Apud: C. Rodrigues de Oliveira, p. 94-99;128-135.

${ }^{151}$ Florbela Veiga Frade. As relações econômicas e sociais das comunidades sefarditas portuguesas. O trato e a Família -1532-1632. op. cit. Apud: João Brandão. Grandeza e Abastança de Lisboa em 1552. Lisboa: 1990, p. 199.

152 Idem, p. 166.

153 Esses números, citados em termos absolutos por David Grant Smith, fazem parte do relatório de Cristovão Rodrigues de Oliveira, em seu compilamento estatístico de 1555. O numero mais reduzido de mercadores relevantes foi calculado por David Grant Smith. The Mercantile Class of Portugal in the Seventeenth Century: a Socio-economic Studyf the Merchants of Lisbon and Bahia. Dissertation. The University of Texas. 1975. p. 13-14.

\footnotetext{
${ }^{154}$ James C. Boiajyan. Portuguese Bankers at the Court of Spain, 1983, op. cit. p. 28-36.
} 
realizadas com Flandres; Porém, não constam dessa lista mercadores banqueiros ou mercadores de grosso trato. ${ }^{155}$

\subsubsection{Os cristãos-novos no comércio do Oriente}

A Coroa portuguesa que buscava rota alternativa para atingir as Índias, visando participar do lucrativo comércio do Oriente, conseguiu seu intento em 1498, quando Vasco da Gama contornou o cabo da Boa Esperança, chegando a Calicute, inaugurando a Rota do Cabo. A participação de homens de negócio na Carreira da Índia, enfatizada por Vitorino Magalhães Godinho, caracterizada como sistema, ${ }^{156}$ trata-se de uma "economia de contratos" que envolvia o Estado e mercadores. Isso porque a Coroa portuguesa fazia contratos de longo prazo com investidores privados para que estes financiassem as viagens, visto que a Coroa não tinha recursos para bancar o investimento das armadas para o Oriente.

Entre 1500 e 1530, a Rota do Cabo suplantou amplamente a Rota do Levante como principal fonte de fornecimento de especiarias à Europa. A armada portuguesa conseguiu bloquear, em grande parte, a passagem para o mar Vermelho. ${ }^{157}$ Assim, os portugueses apossaram-se de parte do trato que antes era feito pelo Mediterrâneo e que abastecia a Europa, atraindo, num primeiro momento, as principais famílias de negociantes e banqueiros alemães e italianos, como os Marchione, ${ }^{158}$ Di Nigro, Cremona, Frescobaldi, Gualterrotti

\footnotetext{
${ }^{155}$ Idem, p. 13.

156 Vitorino Magalhães Godinho. Os Descobrimentos e a Economia Mundial. v. 1-4. Lisboa: Presença, 1987.

157 Joaquim Romero Magalhães. Açúcar e especiarias. In: Francisco Bethencourt; Kirti Chaudhuri (Dir.). op. cit., v. 1, p. 303.

${ }_{158}$ Que investira, anteriormente, num dos navios da viagem que descobriu o Brasil. Este mercador, no reinado de D. João II, açambarcou grande parte dos resgates africanos: marfim, escravos,
} 
e Affaitadi, sendo que estes tinham representantes em Lisboa. ${ }^{159}$ Os alemães, Welser, Fugger ${ }^{160}$ e Hoechstetters de Augsburgo, os Imhoff e Hirschvogel de Nuremberg, ${ }^{161}$ tiveram privilégios dados por Dom Manuel, sendo estes donos de grandes cabedais, detentores de minas de cobre e prata no sul da Alemanha. Negociantes italianos liderados por Bartolomeo Marchione, e dois grupos de alemães, os Welser e Voehlin, representados por Lucas Rem; os Fugger, os Hoechstetter, os Imhof e outros, investiram 29.400, 20.000 e 16.000 cruzados, respectivamente, na armação de três navios da armada capitaneada por D. Francisco de Almeida. ${ }^{162}$ Os Welser, com 20.000 cruzados, eram a maior participação na armada portuguesa; os Fugger deram, à semelhança dos Hoechstetter, 4.000 cruzados; os Imhof e os Gossembrot 3.000, cada um; os

malagueta, chegando a pagar à Coroa anualmente pelos contratos mais de 40.000 cruzados. Veio a ter o "trato" dos escravos até 1487 por 6.300 .000 reais; o dos rios da Guiné em 1490-1492 por 1.100.000 por ano e depois em 1493-1495 pelo dobro, pagando muitas vezes antecipadamente. No reinado de D. Manuel, o mesmo Marchione comprou quatro naus para o rei por 7.037 .578 reais; negocia em açúcar em barris de atuns; prepara uma armada para as Índias em parceria com a Coroa para o comércio do Oriente; preside à companhia de mercadores (sendo parceiro do Rei), passa letras de câmbio para a Flandres e Roma, faz pagamentos à armaria Real de Santarém e ao almoxarife dos paços reais de Muge. In: Vitorino Magalhães Godinho, op. cit., v. III, p.196. 48-54.

${ }^{159}$ A. A. Marques de Almeida. Capitais e Capitalistas no Comércio das Especiarias. op.cit, p.

${ }^{160}$ Os Fugger eram os maiores banqueiros do final do século XV, donos de minas de prata e outros minérios e que dominavam os negócios na Europa. nas primeiras décadas do século XVI, senhores do monopólio da pimenta no comércio entre Lisboa e os Países-Baixos que mantinham conexões com a Inglaterra, cidades italianas e o Império Turco-Otomano. Hans Fugger abandonou em 1367 sua pequena aldeia natal no Lechfeld para radicar-se em Augsburgo como tecelão e tintureiro. Pouco a pouco enriqueceu e seus descendentes, ao lado da tecelagem, dedicaram-se também ao comércio. Um século após a mudança de Hans Fugger para Augsburg, nasceu Jakob Fugger, "o rico”, genial representante do homem de negócios do Renascimento, trabalhador incansável que levou o nome dos Fugger à mais alta glória. Ditou as diretrizes da economia europeia. Dirigiu a política e imiscuiu-se nos negócios eclesiásticos. Os Fugger já não são mais os simples tecelões de fustão e pequenos comerciantes. A maior parte do comércio internacional esteve nas mãos de Jakob Fugger, "o rico"; possuía monopólios, grandes organizações industriais, destacando-se se pelas proporções a mineração no Tirol, na Hungria e na Espanha. Anton Fugger continuou o caminho traçado por seu tio Jakob Fugger, mas logo a decadência se fez notar. Os sucessores de Anton Fugger se preocuparam mais com a obtenção de títulos nobiliárquicos do que com os negócios. A partir da segunda metade do século XVI, os Fugger não na vida econômica da Europa. Maria Thereza S. Petrone. Notas para o estudo das relações dos banqueiros alemães com o empreendimento colonial dos países ibéricos na América no século XVI Revista de História. São Paulo, n. 142-143, p. 11, 2001, p. 11.

${ }^{161}$ Idem.

${ }^{162}$ Vitorino Magalhães Godinho, op. cit., p.58 
Hirschvogel 2.000; os restantes 31.400 cruzados saíram dos bolsos e florentinos ${ }^{163}$

Em 1506 os Welser investiram juntamente com os Imhoff de Nuremberga e o português Rui Mendes - desta vez apenas com cerca de 3.500 Cruzados - em três dos 15 navios, que partiram sob o comando de Tristão da Cunha para as Índias. Como se perderam dois dos três navios já na ida para a Índia, essa expedição terminou para os investidores germânicos num fracasso. Nas décadas seguintes, alguns dos mercadores-banqueiros alemães desistiram da sua participação financeira nas aventuras ultramarinas portuguesas, o que se explica não apenas com o insucesso da empresa de 1506, mas, em primeiro lugar, pela política monopolista de D. Manuel I.

Em 1506 foi instituído o monopólio real da Rota do Cabo. ${ }^{164}$ Em outras palavras, a armação da frota, a compra, a expedição da prata com o Oriente eram competências exclusivas da Coroa, e somente ela poderia importar pimenta e as especiarias, além de outros bens, como o coral. ${ }^{165}$ Mais do que isso, o monopólio régio refletia o domínio real sobre o trato, enquadrando-o legalmente sob seus auspícios.

Para se ter ideia do volume desse rico trato, em 1512 foram despachados ao Reino cerca de 42 mil quintais de pimenta. ${ }^{166}$ Era a reexportação que garantia a parte mais significativa da remuneração do capital, e parte dele invertido em novos empreendimentos na busca de especiarias.

\footnotetext{
${ }^{163}$ Hermann Kellenbenz. Los Fugger en España y Portugal hasta 1560. Bertrand: Junta CastillaLeon, 2000, p. 61.

${ }^{164}$ Vitorino Magalhães Godinho, op. cit., p. 58.

${ }^{165}$ Idem, op. cit., p. 58.

${ }^{166} \mathrm{Um}$ quintal equivalia a $45,3 \mathrm{~kg}$, portanto, aproximadamente 19 toneladas. Kirti Chaudhuri. O estabelecimento no Oriente, op. cit., p. 186.
} 
Apenas $8 \%$ do total das especiarias que chegavam a Lisboa eram suficientes para abastecer o Reino. ${ }^{167}$

O tráfico marítimo luso, o das especiarias das Índias por Lisboa e as trocas com a África, em 1506, representava $65 \%$ do total das receitas régias e $68,2 \%$ entre 1518 e 1519.

Na primeira década do século XVI a companhia dos Welser ${ }^{168}$ efetuou em Portugal, segundo Lucas Rem, "um volumoso e considerável comércio", vendendo cobre, chumbo, vermelhão, mercúrio, panos flamengos e cereais para comprar, sobretudo, especiarias e ainda azeite, vinho, figos, marfim, e algodão. Também o açúcar madeirense ganhou um papel de relevo nas importações dos Welser, que possuíram, a partir de cerca de $1507 .{ }^{169}$

Em 1506 foram declaradas competências exclusivas da Coroa, e somente ela poderia importar pimenta e determinadas especiarias, além de outros bens, como o coral. ${ }^{170}$ Mais do que isso, o monopólio régio refletia o domínio real sobre o trato, enquadrando-o legalmente sob seus auspícios.

${ }^{167}$ Joaquim Romero Magalhães. Portugueses no Mundo do Século XVI. op. cit., p. 50.

${ }^{168}$ O primeiro negócio importante efetuou-se no Verão de 1504 . No seu diário lê-se: "No dia 1 de Agosto fizemos o contrato com o rei de Portugal, acerca da armação de três navios com destino à Índia." Trata-se aqui da armada de D. Francisco de Almeida, que partiu para a Índia em 1505. Esta expedição contou com a participação financeira de um consórcio, composto por várias companhias alemãs, nomeadamente os Welser, Fugger, Höchstetter e Gossembrot de Augsburg, tal como os Imhoff e Hirschvogel de Nuremberga. Este consórcio, que incluiu também alguns mercadores-banqueiros de Génova e de Florença, investiu um capital de 65.400 Cruzados em três navios daquela frota, sendo os Welser o maior investidor, a contribuir com 20.000 Cruzados, ou seja, quase um terço do total. Na pessoa de Balthasar Springer viajou também um representante dos Welser e das outras casas comerciais de Augsburgo para a Índia. Ao serviço das casas de Nuremberga fez Ulrich Imhoff, o feitor dos Hirschvogel em Lisboa, a viagem. Quando a frota voltou a Lisboa em 1506 os negócios com a coroa portuguesa complicaram-se bastante, porque D. Manuel I tinha, entretanto, monopolizado o comércio da pimenta e recusava-se agora a entregar aos comerciantes alemães as mercadorias a que tinham direito. Seguiram-se processos muito morosos até se chegar a um acordo. Apesar destas contrariedades os Welser conseguiram tirar grande proveito daquela empresa. Pelas indicações de Lucas Rem o lucro rondou os $150 \%$. Jürgen Pohle. Agentes comerciais alemães em Lisboa e seus testemunhos (1503-1512) [Comunicação proferida no âmbito do Workshop "Cônsules e mercadores estrangeiros no Império Português "(29.11.2011), Universidade Nova de Lisboa/ CHAM].

169 Jürgen Pohle. Casa comercial dos Welser. Enciclopédia Virtual da Expansão Portuguesa (EVE), Lisboa, 1/2012. Centro de História de Além-Mar (CHAM).

${ }^{170}$ Idem, p. 63. 
Os altos custos das armadas e das expedições além da manutenção da corte e da nobreza sugavam as receitas do erário real. Em 1500, D. Manoel introduziu os "padrões de juros", que na verdade eram os empréstimos de particulares à Coroa. ${ }^{171}$ Os italianos e alemães foram os primeiros financiadores da Coroa portuguesa, como também os irmãos portugueses e cristãos-novos Diogo Mendes ${ }^{172}$, em Antuérpia, e Francisco Mendes em Lisboa, juntamente com os Affaitadi, eram os grandes financistas e mercadores em relação às especiarias.

O comércio com o Oriente era feito com mercadorias de luxo e transacionado com mercadorias de alto valor especulativo e seu consumo era relativamente pequeno comparado ao seu mercado potencial ${ }^{173}$. Inegavelmente esse comércio trazia grande retorno aos grandes mercadores. Porém, tratantes e outros com menor capital também desejavam participar do rentável negócio e associavam-se, grande parte das vezes em consignação, a esses homens de grandes cabedais, no algodão e seda asiáticos, diamantes, especiarias, que ganhavam consideráveis comissões com essas joint-ventures. ${ }^{174}$

171 O primeiro "padrão" ocorreu a 20 de fevereiro de 1500 , e vencia o juro anual de $7,14 \%$ Destinava-se às despesas da guerra em África. Correa, História Econômica, I, 273. Apud. José Gonçalves Salvador. Magnatas do tráfico negreiro. São Paulo: Pioneira, 1989, p. 72.

172 Conforme Maria José Ferro Tavares, os Mendes eram tão importantes em termos econômicos e políticos para a Coroa portuguesa que o próprio D. João III intercedeu junto a Carlos V pela libertação de Diogo Mendes, denunciado como judaizante. Maria José Ferro Tavares. . Os judeus em Portugal no século XV. Lisboa: Universidade Nova de Lisboa, 1982, p. 146; Os Mendes descendiam de uma poderosa família de mercadores-banqueiros, com raízes em Castela a família de Abraão Benveniste que fora tesoureiro nesse reino, que em 1492, transferiu-se para Portugal, fugindo da Inquisição. Tinham relações privilegiadas com os mais poderosos reis europeus, inclusive com o imperador Carlos $\mathrm{V}$, a quem concediam grandes empréstimos. Os irmãos Francisco e Diogo Mendes entraram no comércio das especiarias e Diogo mudou-se para Antuérpia em1512, na cidade de Antuérpia, contatando e negociando com as principais casas comerciais alemãs, enquanto Francisco ficou em Lisboa cuidando diretamente dos negócios, onde tinha grande intimidade com o rei e monopolizava a venda da pimenta. Florbela Veiga Frade. Uma família Sefardita do Século XVI. Cadernos de Estudos Sefarditas no 3, Cátedra de Estudos Alberto Benveniste, Lisboa. 2003. p. 127-155.

${ }^{173}$ Paolo Bernardini; Norman Fiering (Ed.). The Jews and the Expansion of Europe to the West 1450- 1800. The John Carter Brown Library, 2001.

${ }^{174}$ Mauro,Le Portugal et L'Atlantique,526, e Fréderic Mauro, L'Atlantique Portugais et les esclaves (1570 -1670, Revista da Faculdade de Letras, Universidade de Lisboa, $2^{\circ}$ semestre, 22 (1956). 
Logo ficou clara a debilidade financeira da Coroa e sua

incapacidade em bancar e investir no negócio da especiaria. O recurso a

capitais alheios, logo tentado por D. Manuel, ditou a dependência econômica

da Coroa e comprometeu de maneira irreversível, o futuro da empresa. Tudo o

que viria a seguir, estratégia do monopólio incluída, foi uma tentativa de suprir

essas necessidades. ${ }^{175}$

Em Portugal, desde meados do século XVI pode-se constatar a

presença de importantes famílias cristãs-novas nos principais contratos com

Coroa. ${ }^{176}$ No comercio asiático estavam os contratos mais lucrativos, como os da pimenta. ${ }^{177}$

Os Affaitadi controlaram, a partir de 1525, o comércio das especiarias e detinham o monopólio de importação, pagando ao rei entre 600.000 e 1.000.000 de cruzados, controlando o capital necessário para a empreitada do

Apud: James C. Boyajian. New Christians and jews in the sugar trade. p. 472. In: Paolo Bernardini; Norman Fiering (Edited). The jews and the expansion of Europe to the West 1450-1800, op.cit p. 283.

175 A.A. Marques de Almeida. Capitais e capitalistas no negócio da especiaria - O eixo Lisboa - Antuérpia (1501-1549), op.cit. p. 24.

${ }^{176} \mathrm{O}$ sistema de contratos pelo qual a Coroa portuguesa transferia para particulares a cobrança de taxas, rendas e direitos reais foi importante meio do Estado realizar receitas. Os contratos eram acordos temporários, com prazos determinados, precedidos por arrematação e fixação do valor contratado. A Coroa repassava os monopólios régios à classe mercantil portuguesa e a negociantes estrangeiros, como, por exemplo, os de Gênova e de Flandres. Os contratadores ligados à Coroa lusa eram, na sua maioria, financistas e mercadores de grandes cabedais que atuavam no atacado, nas torças que envolviam grandes volumes e recursos financeiros. Esses homens eram conhecidos como mercador de grosso trato. A articulação entre a Coroa e os mercadores de grosso trato atendia às práticas mercantilistas típicas do Antigo Regime. Para Jorge Pedreira, a divisão de contratos entre membros da sociedade lusitana, identificada por privilégios e rígida hierarquicamente era essencial na definição da hierarquia do segmento mercantil. A arrematação dos contratos refletia as esferas de influência da elite mercantil lusa no jogo político português. Para Jorge Pedreira, "A contratação de rendimentos e monopólios régios constituía, assim, um poderoso instrumento de acumulação e de influência e, como tal, funcionava como um fator de diferenciação ou discriminação no interior do corpo de comércio, propiciando a formação de uma elite.”. In: Jorge Miguel Viana Pedreira. Os homens de negócio da praça de Lisboa de Pombal ao vintismo (1755-1822): diferenciação, reprodução e identificação de um grupo social. Lisboa. 1995. Tese (Doutorado em Sociologia) - Faculdade de Ciências Sociais e Humanas, Universidade Nova de Lisboa, p. 154. $19 ; 33$.

177 James Boyajian. Portuguese Trade in Asia under the Habsburgs, 1580-1640, op. cit., p. 11; 
comércio com o Oriente, ficando o monarca à mercê desses financistas. ${ }^{178}$ Os Mendes-Affaitadi dominaram o negócio da pimenta e da especiaria na primeira metade do século XVI.

Em 1570, com sucessivos déficits reais aos mais importantes grupos estrangeiros de comércio, faziam com que a Coroa agisse, não raro, contra seus próprios interesses. ${ }^{179}$ Boyajian nos diz que os cristãos-novos chegaram a dominar a maior parte comércio com o Oriente, trato que era controlado por poucas famílias, ${ }^{180}$ caracterizando-se por se comportar como um cartel. ${ }^{181}$ Os financistas e banqueiros alemães e italianos foram os grandes contratadores da pimenta de meados do dezesseis até por volta de 1590. Em 1586, os contradores da pimenta eram um consórcio formado por entre os Fugger, Welser, Rott-Rovalesca (estes com a maior parte), e que esses grupos já tinham arrematado contratos anteriormente. Com a derrota da Invencível Armada (1588) perante a Inglaterra e da Guerra contra os Países Baixos, Filipe II instituiu uma nova política fiscal que alterava a remuneração dos contratadores da pimenta. Dessa forma, em 1593, os Fugger, Welser, RottRovalesca não tiveram mais interesse em continuar com os contratos da pimenta e consideraram a Carreira da Índia muito arriscada e o retorno pouco atraente.

Por volta de 1590, o negócio da pimenta passou para as mãos de meia dúzia mercadores de grosso trato, representantes das mais proeminentes

${ }^{178}$ Hermann Kellenbenz, entrada Mendes, Diogo. In: (dir). Joel Serrão. Dicionário de Portugal. Lisboa: Iniciativas Editoriais, 1968, v. III. p. 16.

${ }_{179}$ Joaquim Romero Magalhães. Portugueses no Mundo do Século XVI: op. cit., p. 88.

180 Tinoco, Fernandes, Silveira, Gomes Denis e Solis, Brandão e Vaaz de Souza. James Boyajian. Portuguese Trade in Asia under the Habsburgs, 1580. Baltimore: The Johns Hopkins University Press, 1992 , p.38.

${ }^{181}$ Ibidem, p. 38; 39. 
famílias cristãs-novas lisboetas, unidas por fortes laços e aparentadas entre si, que também compartilhavam investimentos comuns. Embora houvesse cristãos-velhos na Carreira das Índias, a preponderância era dos sefarditas.

Em 1596, o contrato da pimenta foi inteiramente feito com mercadores e financistas portugueses, que já vinham investindo nos consórcios dos Fugger, Welser, Rott-Rovalesca, e que eram grandes comerciantes de pimenta na Europa. Os maiores investidores eram os Tomás Ximenes de Aragão e Heitor Mendes de Brito, seguidos por outras famílias lisboetas como os Gomes d'Elvas, os Rodrigues d'Evora e Veiga, os Rodrigues Solis, os Coronel os Angel, entre outros. ${ }^{182}$

O contrato da pimenta enquanto monopólio real revelava a grande capacidade econômica e financeira daqueles que participavam do consórcio da pimenta e ao mesmo tempo o alto grau de influência política junto à Coroa.

\subsubsection{O papel de Antuérpia}

Antuérpia já realizava feiras de comércio no final do século XV e foi escolhida, em 1498, para sediar uma feitoria portuguesa que garantisse a distribuição e abastecimento do norte da Europa, centro estratégico para as áreas circundantes e próximas dos mares do Norte e Báltico dos produtos do monopólio real colonial. Antuérpia desenvolveu-se não só com a distribuição das especiarias, mas também com óleo, frutas, entre outras mercadorias lusas e o comércio do sal elevou-a ainda mais como centro distribuidor, agora não só mais português, tornando-a um grande depósito de mercadorias a serem distribuídas na Europa.

${ }^{182}$ James C. Boyajian, Portugues Bankers, op. cit., p. 27; 117. 
A partir de 1525 , as casas de comércio passaram a trabalhar também com finanças, tornando-se centro financeiro, praça de câmbio vital entre regiões européias, sendo o câmbio (e o recâmbio, com juros) que alimentava as estruturas sociais. ${ }^{183}$ Também aí se instalou uma expressiva colônia mercantil espanhola, passando os negócios das Coroas ibéricas a serem realizados majoritariamente na cidade. Ao longo do século XVI, Antuérpia tornou-se o centro econômico mais importante do continente. Uma numerosa colônia de comerciantes flamengos fixou-se em Lisboa para vitalizar o trato. Mercadores italianos e alemães fundaram grandes casas comerciais na capital lusa reexportando os produtos asiáticos e africanos para o Leste da Europa e para o Médio Oriente.

A consolidação e os bons resultados da Rota do Cabo e a venda das especiarias na Europa resultaram da ação decisiva da Coroa na condução da empresa expansionista conjugada aos interesses de mercadores e banqueiros, locais e estrangeiros. Estes participavam dos empreendimentos por meio de empréstimos e nos contratos para construir embarcações e prepará-las para integrarem as armadas que saíam de Lisboa com destino ao Índico. ${ }^{184}$

Em 1566, Antuérpia era uma cidade com aproximadamente 90 mil pessoas. Os portugueses não eram mais de mil ao total. Em 1567, por levantamentos feitos sobre as taxações de imóveis e Antuérpia, sabemos que muitos portugueses aparecem entre os mais ricos da cidade, sendo grandes proprietários de imóveis. Os Rodrigues d' Evora e os Ximenes tinham cerca de 17 propriedades tanto no campo como palácios. Os Ximenes eram donos do

183 José Gentil da Silva. O eixo econômico Lisboa-Antuérpia. Anais da Exposição Portugal e Flandres, visões da Europa (1550-1680). Lisboa: Instituto Português do Patrimônio Cultural Mosteiro dos Jerónimos, abr.-maio 1992, p. 2.

${ }^{184}$ Idem. p. 61. 
castelo Basel em Flandres Oriental, a oeste de Antuérpia, e os Rodrigues d'Evora de Destelbergen, próximo a Gand Charles Verlinden. ${ }^{185}$ A tomada de Antuérpia pelos espanhóis em 1585, provocou uma migração de mercadores flamengos para Holanda, onde os criptojudeus regressos ao judaísmo fundaram uma comunidade judaica portuguesa na última década dos Quinhentos. Comunidade que contava com mais ou menos 200 homens ao findar o século XVI, como relata Manuel Homem, cristão-novo que lá esteve na primeira década dos seiscentos. ${ }^{186}$

Estudos historiográficos mais recente vêm apresentando nova perspectiva sobre a posição de Antuérpia em fins do século XVI e início do XVII. ${ }^{187}$ Embora tenha deixado de ser o "empório da Europa", a grande distribuidora de mercadorias que a caracterizou no decorrer do século XVI, continuou a ter importância no trato, com agentes muito atuantes das principais redes de comércio. ${ }^{188}$ Entre esses agentes estavam os filhos de Rodrigo d' Andrade e Ana de Milão, Jorge e André d'Andrade ${ }^{189}$, associados a aos Ximenes, que continuavam sendo expoentes na cidade do Escalda.

\subsection{A virada para o Atlântico}

Por volta da metade do século XVI, o Império Português assentou-se em dois eixos mercantes diferenciados: o do Atlântico Sul, que tomava corpo com a produção de açúcar e com o tráfico negreiro, e o do Índico que havia diversificado seus produtos e gêneros, não mais focado apenas nas

${ }^{185}$ Les propriétes jonciéres des marchands ibériques d'Anvers au XVe siécle In: Revista En la España Medieval, v. 6. Madrid: La Ciudad Hispânica. Editorial de la Universidad Complutense, 1985, p. 125-127.

\footnotetext{
${ }^{186}$ ANTT. Inquisição de Lisboa. Processo 12065.

${ }^{187}$ Florbela Veiga Frade. As Relações Econômicas e Sociais... op. cit.

188 Joaquim Romero Magalhães. Portugueses no Mundo do Século XVI, op. cit., p. 56.

${ }^{189}$ Studia Rosenthaliana 986.
} 
especiarias. Esses espaços do Império português, diferenciados em sua construção, surgiram da política de expansão ultramarina lusa centrada na conquista, transporte e fixação dentro da premissa de um espaço em ampliação que só pode ser compreendido em seu conjunto. ${ }^{190}$

A partir do século $\mathrm{XVI}$, o Atlântico, abriu nova perspectiva no comércio transcontinental, transformando a dinâmica da economia mundial. O trato monopolístico deixou de existir - como vinha acontecendo no Mediterrâneo, com os genoveses, e no Índico, com os portugueses, ambos com as especiarias - e nem em dois eixos como Lisboa e Antuérpia. Os centros comerciais deixaram de ser hierarquizados, destacando-se cidades como Lisboa, Amsterdã, Pernambuco, Porto, Hamburgo. ${ }^{191}$ A nova dinâmica do comércio colonial não se sustentava mais nos moldes das casas comerciais mantidas pelos Fugger, Affaitadi, com representantes remunerados em locais fixos, com pouca mobilidade. Assim, o comércio estruturou-se em um sistema de correspondentes distribuídos entre todos os mercados importantes, sem obrigações contratuais, nem salários, mas sim pela prestação recíproca de serviços e comissões. ${ }^{192}$

Novos núcleos urbanos e portuários passaram a integrar e a ter importância no comércio europeu e transcontinental ligados ao sistema Atlântico. O Atlântico era basicamente movimentado pelas redes de comércio dos cristãos-novos. ${ }^{193}$ Esses comerciantes organizaram-se em várias e extensas redes de longo alcance, pessoas empreendedoras que tinham

\footnotetext{
${ }^{190}$ Joaquim Romero Magalhães. Articulações Inter-Regionais e Economias-Mundo. In: Francisco Bethencourt; Kirti Chaudhuri, (Dir.), op. cit., v. 2, p. 312.

${ }^{191}$ Leonor Freire Costa, O Transporte no Atlântico, v 1, op cit. p 91-100, 123, 129-130; António Fernandes Moreira. Os Mercadores de Viana e o Comércio do Açúcar Brasileiro, p. 206;

192 Eddy Stols. Os Mercadores Flamengos em Portugal e no Brasil, p. 29-30. Apud: Daniel Strum. The Portuguese Jews and New Christians in the Sugar Trade, op. cit,. p. 238.

${ }^{193}$ Amândio Morais de Barros, op. cit., p. 270-278.
} 
ligações com algumas das mais importantes casas comerciais da época. A redistribuição de produtos coloniais, como o açúcar e o algodão brasileiros, fazendo o transporte destes até ao norte europeu.

Uma das principais rotas identificadas por Hilário Casado Alonso foi a do Brasil, que fazia circular tecidos, alimentos e manufatura europeias, em troca de açúcar e algodão brasileiros. ${ }^{194}$ As rotas marítimas foram interconectadas por meio das trocas. $O$ trato no Báltico estava vinculado ao comércio no Atlântico, visto que as trocas de produtos originários de uma região eram transportadas para outro, como também circulavam capitais e pessoas nesses circuitos. ${ }^{195}$

De uma forma geral, os agentes mercantis movimentavam-se pelos os espaços por onde passava o produto (ou seguiam o seu movimento através de correspondentes e parceiros comerciais estrategicamente colocados). No caso do trato de produtos brasileiros, acompanhavam desde a sua produção ou origem, distribuíam os produtos no continente europeu e lá mesmo carregavam as embarcações com tecidos, vinhos e óleos que traziam ao Brasil. Desta forma, eram também esses mercadores protagonistas das ligações entre "Portugal e os portos europeus de Bordeaux, Nantes, Rouen, Londres, Hamburgo e Antuérpia. Era a troca de produtos e especiarias por produtos manufaturados, sobretudo têxteis". ${ }^{196}$

Os pioneiros da expansão ultramarina, Portugal e Espanha dominavam o tráfego no Atlântico e tinham o controle do comércio triangular entre Europa, África e Brasil. O açúcar era o motor do trato que envolvia o tráfico negreiro

194 Casado Alonso. Revista da Faculdade de Letras-História. Porto, III série, v. 4, 2003, p. 218219.

195 Cátia Antunes, Globalalizationin the Early Modern Period, op. cit., p. 134-142.

196 Idem, p. 145. 
africano, o açúcar brasileiro e os produtos trazidos do Reino para a Colônia. Os metais preciosos saiam do México e das Índias de Cartagena com direção a Sevilha, na Espanha. A união dos Reinos português e espanhol sob um mesmo monarca intensificou a importância do Atlântico enquanto caminho das diversas rotas comerciais. A União Ibérica (1580-1640) ampliou a as possibilidades de comércio entre Portugal e Espanha, visto que os mercadores portugueses já estavam envolvidos anteriormente no comércio de escravos com a América espanhola. ${ }^{197}$

Com o passar do tempo, outros europeus, com interesses mercantis crescentes no Novo Mundo passaram a cruzar o Atlântico, de forma legal ou ilegal.

\subsection{A implantação da empresa colonial}

A fixação e ocupação das Ilhas atlânticas tinham orientação diferente daquela empreendida para a conquista do Marrocos que se restringiu ao estabelecimento de feitorias no litoral africano. O caráter da exploração, entretanto, continuou sendo mercantil, fruto do desdobramento da expansão comercial que, por especificidades das áreas atlânticas, incorporou a produção como forma de valorizar economicamente as áreas periféricas do Império Português e inseri-las na economia da expansão. ${ }^{198}$

${ }^{197}$ Leonor Freire Costa. Portugal e o Atlântico: o significado do império. Palestra proferida no Simpósio Internacional Novos Mundos. Portugal e a Época dos Descobrimentos. Deutsche Historisches Museum, em Berlim, 23 a 25 de Novembro de 2006. p.4-5.

${ }^{198}$ Fernando A. Novais. O Brasil nos Quadros do Antigo Sistema Colonial, op. cit., p.52. 
A ocupação da Madeira não acarretou problemas para Portugal, visto esta ser desabitada e pelo princípio res nulius que garantia o direito de posse ao descobridor das terras. A política colonizadora só conseguiu sucesso na década de 1430, com medidas tomadas pelo Infante D. Henrique para o seu povoamento e aproveitamento econômico.

A exploração das llhas Atlânticas, em especial da Madeira, visava complementar a economia portuguesa. Fernando Novais quem melhor sintetiza o caráter da colonização lusa em suas possessões ultramarinas do Atlântico: "a colonização tinha um caráter essencialmente comercial, voltada para fora, mas, para além disso, compunha um mecanismo de estímulo à acumulação primitiva de capital autônomo dentro do sistema."199

Em termos administrativos e jurídicos a colonização da Madeira deu-se pelo sistema de capitanias hereditárias, através do qual o rei doava faixas de terras a homens, chamados de capitães-donatários, que deveriam ocupá-las, defendê-las e colonizá-las. Em um primeiro momento, a exploração econômica fixou-se na extração de madeira nativa que era levada para Portugal. As condições naturais da ilha - como clima ameno e solo fértil - favoreceram a implantação da cultura de cana-de-açúcar, da qual se obtinha o açúcar, um produto raro e de alto valor de troca na Europa. Em pouco tempo a atividade extrativa cedeu lugar à cultura açucareira que se expandiu rapidamente.

Mercadores europeus, em especial, genoveses e judeus oriundos de diversos pontos da Europa, foram atraídos pelo novo negócio. A atuação desses homens de negócio ${ }^{200}$ deu-se em praticamente em todas as esferas da

\footnotetext{
${ }^{199}$ Fernando A. Novais. Prefácio. Laura de Mello e Souza (Org.). História da Vida Privada no Brasil: cotidiano e vida privada na América portuguesa. São Paulo: Companhia das Letras, 1998, p. 31.

${ }^{200}$ Entende-se por homens de negócio, comerciantes de grosso trato, financistas, contratadores, banqueiros, investidores, entre outros.
} 
produção: no financiamento das plantações e da infraestrutura produtiva, no fabrico do açúcar e na compra de safras antecipadas. A necessidade de mãode-obra para as lavouras de cana foi suprida com a escravização de negros da Guiné, Angola e Congo, regiões da costa ocidental da África. O aprisionamento e a venda de negros como escravos revelaram-se um dos mais lucrativos negócios do período. Em 1455, a produção de açúcar madeirense era de 1.400 arrobas, subindo para 20.000 em 1470, e no final da centúria atingiu 105.000 arrobas. O açúcar era levado para o Reino, de onde era reexportado para diversas regiões da Europa. A presença de estrangeiros no negócio do açúcar fazia concorrência aos naturais do reino. Apesar de o monopólio real da exploração ultramarina ter sido retomado por D. João II, em 1469, fracassou a tentativa régia de manter o trato exclusivo dos mercadores lusos. O comércio continuou aberto a todos os interessados, embora tenham sido implantadas "cotas de produção" para garantir os preços e a qualidade do produto.

A insatisfação dos comerciantes portugueses aumentou pelo fato das taxas cobradas pela Coroa não se estenderem aos estrangeiros. Diante disso, D. João II determinou a criação de taxas a serem pagas pelos comerciantes que não fossem portugueses e determinou que eles deviam deixar o ultramar no prazo de um ano. O exclusivo comercial era implantado. ${ }^{201}$

Em 1498, do total do açúcar exportado da Madeira, cerca de 7.000 arrobas abasteceriam Portugal e igual quantidade cobriria a demanda de Castela. Era previsto o envio de 40.000 arrobas para Flandres; Rouen, 6.000; Inglaterra, 7.000; Bretanha, 1.000; La Rochelle, 2.000; Gênova, 13.000; Veneza, 15.000; Chios e Constantinopla, 15.000; Porto Lione 6.000. A 
atividade açucareira na Madeira perdeu importância a partir de 1570, quando concorrentes americanos, e de São Tomé e Canárias tomaram-Ihe o mercado. $^{202}$

Em São Tomé, no início do século XVI, a colonização da ilha deu-se pelo açúcar, contando com a colaboração de técnicos madeirenses e genoveses para a implementação das lavouras. Na década de 1560 existiam cerca de 60 engenhos que produziram 150 mil arrobas. São Tomé tornou-se também importante ponto no Atlântico, onde escravos retirados da África aguardavam a ida para a América, onde eram utilizados na economia açucareira em expansão.

Schwartz afirma que em São Tomé ajustaram-se e interconectaram-se todos os elementos do sistema da grande lavoura, orientada para a produção de uma cultura altamente comercializável, baseada na escravidão para fornecer a mão-de-obra necessária. O sistema de grande lavoura, ou regime dos engenhos desenvolveu-se rapidamente." ${ }^{203}$ Essa forma de produção agrária seria transportada para o Brasil. A territorialidade do Império passava a existir como forma de complementar a economia metropolitana e fortalecê-la. A ocupação e colonização inseriam-se como desdobramento da expansão mercantil, sendo a produção organizada de modo a possibilitar aos empresários metropolitanos ampla margem de lucros. ${ }^{204}$

O Brasil, até a década de 1530, concorreu para a economia do Reino com atividades extrativas, como o pau-brasil, do qual se retirava um corante rubro usado na tinturaria têxtil. A exploração do pau-brasil era monopólio real e foi arrendado a particulares cristãos-novos, em 1503. Pela ação corsária no

\footnotetext{
202 Joaquim Romero Magalhães. Açúcar e especiarias. op. cit., p. 300-301.

${ }^{203}$ Stuart B. Schwartz. Segredos Internos. op. cit., p. 30.

${ }^{204}$ Fernando A. Novais. O Brasil nos Quadros do Antigo Sistema Colonial. op. cit., p. 47.
} 
litoral brasileiro, especialmente a francesa, e o temor de perder as terras americanas, como também pelo enfraquecimento das receitas do comércio asiático, Portugal empreendeu a colonização de sua colônia americana.

A experiência anterior do fabrico do açúcar foi essencial na opção pela introdução da lavoura canavieira no Brasil, além do alto valor de troca que essa mercadoria tinha na Europa.

Os cristãos-novos portugueses tiveram, em fins do século XVI e início do XVII, um papel fundamental no desenvolvimento do comércio ultramarino e na exploração colonial realizada pelas metrópoles europeias. Além disso, foram atuantes também no trato que se constituiu na mola propulsora do sistema colonial e que articulou outros processos da economia atlântica: o tráfico de escravos.

Os contratos envolviam o trato lícito de escravos africanos para a América, embora o contrabando fosse uma enorme fonte de riqueza para os contratadores e os licenciados. ${ }^{205} \mathrm{O}$ tráfico negreiro tornou-se uma atividade enormemente lucrativa na segunda metade do século $\mathrm{XVI}$, estando concentrado nas mãos dos mercadores portugueses cristãos-novos ${ }^{206}$.

A cana-de-açúcar foi trazida para o Brasil, embora não se possa precisar com exatidão sua chegada e o início de seu cultivo. Segundo informa Schwartz, em 1519, havia em Antuérpia açúcar proveniente do Brasil; em 1526, a alfândega de Lisboa deu entrada de açúcar produzido no Nordeste brasileiro. ${ }^{207}$

Em 1532, Martim Afonso de Souza liderou uma expedição ao Brasil que tinha o objetivo de afastar os piratas franceses das costas brasileiras e dar

\footnotetext{
205 José Gonçalves Salvador. Os Magnatas do Tráfico Negreiro, op.cit, p. 33-38.

${ }^{206}$ Idem p. 195-196.

${ }^{207}$ Stuart B. Schwartz, Segredos Internos. op. cit., p. 31.
} 
início ao projeto colonizador. Com ele, foram trazidas mudas de cana, e técnicos portugueses, flamengos e italianos com experiência no fabrico do açúcar. Poucas capitanias tiveram sucesso em ocupar produtivamente a Colônia. Entre os maiores problemas destacavam-se o fato de muitos capitães não terem vindo tomar posse de suas terras, a hostilidade dos nativos e a distância entre uma capitania e outra, isolando comunidades.

A partir das décadas de 1530 e 1540, a empresa açucareira tomou corpo e volume. Mudas de cana trazidas de São Tomé espalharam-se pelo território e a atividade sacarina desenvolveu-se na Bahia, em Pernambuco (a região mais bem-sucedida), no Espírito Santo e em São Vicente. ${ }^{208}$

Apesar dos problemas ligados ao regime de capitanias, D. João III, interessado na expansão da atividade sacarina, optou por uma política de intervenção mais direta da Coroa para incentivar a colonização do Brasil. $O$ regimento régio que foi concedido em 1548 a Tomé de Souza, capitão da capitania da Bahia e governador-geral do Brasil, manteve o sistema de donatários, que se reportavam ao governador, ficando com a Coroa as questões ligadas à administração da justiça e fiscais. ${ }^{209}$

Os donatários obtiveram importantes isenções relativas à exportação de açúcar, e o governador-geral tinha o poder de doar sesmarias aos interessados em estabelecer engenhos, mas "a pessoa que o possa fazer dentro do tempo que Ihe limitardes." ${ }^{210}$ Além disso, os que ganhavam as terras deveriam morar em Salvador ou na sesmaria durante três anos, para ter o direito de vendê-la. Era claro no regimento a intenção real em promover a disseminação da canade-açúcar e dos engenhos para o fabrico do açúcar. As lavouras de açúcar

\footnotetext{
${ }^{208}$ Ibidem, p.47

${ }^{209}$ A. J. Russell-Wood. Fronteiras de integração, op. cit., p. 246-247.

${ }^{210}$ Joaquim Romero Magalhães. Açúcar e especiarias, op. cit., p. 306.
} 
eram vistas como empreendimentos comerciais e para atrair colonos com cabedais para investir na atividade, e também como vetores de ocupação da terra, visto que os que construíam engenhos tinham obrigatoriamente que erguer uma casa-forte para proteger os colonos. ${ }^{211}$

Foi permitido, em 1559, que cada dono de engenho pudesse obter no Congo africano 120 "peças" de escravos. O próprio rei se antecipou à autorização régia e enviou ao Brasil, em 1552, negros escravos provenientes da Guiné. ${ }^{212}$

A larga produção do açúcar brasileiro permitiu a popularização do produto na Europa no século XVI e primeiras décadas do XVII. Proteção e incentivos estatais "permissores da utilização da mão de obra indígena (pelo menos até 1618), favoráveis às isenções tributárias, às franquias de transporte e à flexibilização dos preços" foram fundamentais à implantação e rápido desenvolvimento do setor no período 1550-16502. O crescimento do número de engenhos e da produção acompanhou a "franca tendência ascensional" dos preços até $1620 .^{213}$

Pela atividade açucareira em expansão, as capitanias do norte da colônia portuguesa na América despontavam como região de grande possibilidade de comércio. Os preços [do açúcar] apresentavam uma forte tendência ascendente, com o preço médio do açúcar branco e mascavo subindo mais de 40\% durante esses sete anos [de 1572 a 1579]. Em Lisboa e Londres, os preços parecem ter subido acentuadamente entre 1578 e $1582 .^{214}$

\footnotetext{
211 A. J. Russell-Wood. Fronteiras de integração, op. cit., p. 247.

212 Joaquim Romero Magalhães. Açúcar e especiarias, op. cit., p. 307.

${ }^{213}$ Vera Ferlini, op. cit., p. 87.

${ }^{214}$ Stuart Schwartz. Segredos Internos. op. cit., p. 152.
} 
Essa tendência de alta permaneceria, com algumas baixas eventuais, até a década de $1630 .{ }^{215}$

O Nordeste tornou-se o principal polo açucareiro, destacando-se Pernambuco e Bahia a partir da segunda metade do século XVI. Entre 1570 e 1583, o número de engenhos passou de 23, conforme indica Gândavo, para 66, segundo registro de Fernão Cardim, tornando o Nordeste, a principal região produtora de açúcar no Brasil. Nesse intervalo de tempo, a construção de engenhos em Pernambuco cresceu $8,4 \%$ ao ano e cerca de $5,4 \%$ na Bahia, totalizando 36 unidades em 1583. O número de engenhos na colônia, na década de 1590, era de 115, passando a 200 em 1600 e a 230 em 1610. O aumento na produção, entre 1580 e 1600, refletiu a expansão açucareira na colônia, passando de 300 a 350 mil arrobas para 600.000, no limiar do século. ${ }^{216}$ As exportações brasileiras de açúcar beiravam 700 mil arrobas por volta de $1610 .^{217}$ Estima-se que os 66 engenhos de Pernambuco produziam umas 200.000 arrobas, a umas 3.000 por engenho, logo os 119 [considerandose todos os do Nordeste] devem produzir ao todo umas 300.000 arrobas. Nuns quinze anos, ou pouco mais, o quantitativo de estabelecimentos de fabrico duplicaria, e a produção global também. O crescimento açucareiro prosseguia vigorosamente: em 1.590 estima-se que o dízimo dos açucares do Brasil, se for efetivamente cobrado, renderá 502.500. Como o preço anda então por 800 reis a arroba [...] e o valor da produção total atingiria 1 milhão de cruzados. ${ }^{218}$

Ricos mercadores e financistas de origem sefardita tiveram intensa participação na implementação e desenvolvimento da empresa açucareira,

\footnotetext{
${ }^{215}$ Vera Ferlini, op. cit., p. 60-61.

${ }^{216}$ Leonor Freire Costa, O Transporte, op. cit. p. 168-169.

${ }^{217}$ Stuart Schwartz, Segredos Internos, op. cit. p.168.

${ }^{218}$ Vitorino Magalhães Godinho, op. cit., v. 4, p. 104-105.
} 
investindo capitais diretamente na produção, financiando a construção de engenhos e a compra de mudas de cana. A participação desses homens de negócio no tráfico negreiro foi importante para o abastecimento de mão de obra para as lavouras de cana. Boyajian afirma que a participação dos cristãosnovos destacou-se no financiamento da empresa colonial. Famílias de comerciantes de Lisboa e o Porto, detentoras de grandes cabedais, investiram no Brasil e no comércio do Atlântico. Pernambuco, o mais importante polo açucareiro, desenvolveu-se graças ao suporte das famílias portuguesas com experiência anterior na produção e fabricação de açúcar na Madeira. Eles e seus descendentes tiveram papel preponderante nos primórdios e no desenvolvimento da empresa açucareira, no comércio Atlântico e, mais tarde, nos asientos. ${ }^{219}$ Os cristãos-novos ligados às atividades de mercancia e integrantes ou relacionados aos grupos mercantis lusos, passaram a deslocarse para os centros econômicos em ascensão, principalmente para o Nordeste açucareiro.

Na segunda metade do século XVI, o afluxo de cristãos-novos para o Nordeste brasileiro aumentou significativamente. Comerciantes ligados ou membros dos mais importantes clãs mercantis especializavam-se no escoamento do açúcar, na importação de escravos e de bens do Reino. Eram os cristãos-novos que faziam as conexões mercantis relativas ao comércio e dominavam os mecanismos da economia da Colônia. Essa preponderância era lastreada pelos mais importantes grupos familiares metropolitanos. Feitores e comissários agenciavam os negócios com seus correspondentes na África que asseguravam o tráfico negreiro. Outros agentes respondiam pela execução dos

${ }^{219}$ James C. Boyajian. Portuguese Bankers at the Court of Spain, op. cit., p. 83. 
contratos, como os dos dízimos. Mercadores itinerantes, e os que aqui se fixavam. Esse segmento de negócio tinha base familiar e muitos eram irmãos, sobrinhos, netos dos agentes locais. Os que aqui estavam chamavam os do Reino. $^{220}$ Era uma prática comum mandarem os meninos para serem treinados no trato com os parentes.

O grande interesse residia na rota do Brasil, no trato do açúcar e do algodão, depois de um primeiro período em que o pau-brasil ainda tinha parte considerável neste movimento. Se em 1557 as cargas que o navio Nossa Senhora do Lago traz do Brasil são, por esta ordem, pau- Brasil e açúcar, já em 1565 a caravela Nossa Senhora da Esperança traz primeiramente açúcar e algodão, só depois pau-brasil, o qual vai desaparecendo gradualmente das cargas dali remetidas à medida que a centúria avança. ${ }^{221}$

As operações de cada rede envolviam uma gama maior de mercadorias, entre as quais estava o açúcar. Dessa forma, na maioria das vezes, uma rede era composta por agentes nos mais diversos entrepostos comerciais. Em relação ao açúcar em fins do século XVI, ${ }^{222}$ e começo do XVII, era fundamental que as redes tivessem agentes não só no Reino e no Brasil, mas também no norte europeu, onde eram negociados os melhores fretes e seguros marítimos, extremamente lucrativos e quase indispensáveis, a partir do começo do século XVI. O norte europeu era um destino para o qual quase um terço do açúcar produzido no Brasil era transportado nos últimos anos do século XVII.

${ }^{220}$ Sonia A. Siqueira. A Inquisição Portuguesa e a Sociedade Colonial. São Paulo: Ática, 1978, p. 310 .

${ }^{221}$ Amândio Morais Barros, op. cit., p. 737.

${ }^{222}$ Frei Vicente Salvador. História do Brasil (1500-1627). 7.ed. São Paulo: Universidade de São Paulo; Belo Horizonte: Itatiaia, 1982, p. 21. 


\section{Capítulo 2}

\section{A família e os negócios dos Dias de Milão}

Grande parte das principais famílias cristãs-novas portuguesas descendiam de espanhóis que vieram para Portugal fugindo da Inquisição, mesmo antes da expulsão dos judeus da Espanha em 1492. Muitos deles tinham proeminência na corte espanhola, com fortuna e distinção social. Em Portugal, essas famílias reagruparam-se em torno de suas antigas relações econômicas e sociais, reproduzindo suas crenças e modo de vida trazido do reino vizinho.

Em 1497, a conversão forçada ordenada por D. Manuel não implicou na mudança da fé na Lei mosaica para a cristã, permanecendo muitos judeus com suas crenças secretamente e mantendo suas tradições, fechando-se em seu grupo étnico, o que resultava em casamentos endogâmicos como forma de preservar as tradições ancestrais, a cultura e a unicidade do grupo.

As famílias cristãs-novas acompanharam e tiveram participação ativa na expansão mercantil ibérica e europeia, presentes na Rota do Cabo, na empresa açucareira e no tráfico negreiro. Organizaram-se em redes de comércio que reproduziam a própria dinâmica familiar, restritas ao grupo étnico ao qual pertenciam, protegidas pelos casamentos endogâmicos, e estes como estratégias para evitar o alargamento das redes, evitando a entrada de estranhos ao grupo e protegendo o capital. 


\subsection{A família Dias de Milão}

As redes de comércio caracterizavam por sua ação intra e transcontinental, formadas por mercadores que colocavam agentes itinerantes distribuídos estrategicamente pelos principais pontos de interesse do trato e a importância das casas comerciais que formavam os grupos mercantis.

Para Fréderic Mauro, o trato intercontinental estava nas mãos de um número reduzido de comerciantes com enormes cabedais, responsáveis por transações de grande vulto, partícipes do comércio marítimo, proprietários de embarcações (ou parte delas), com considerável patrimônio e atuavam em diferentes segmentos do comércio internacional e também na banca. Eram mercadores-banqueiros com influência nacional e internacional. As relações familiares dessa elite mercantil eram feitas no mundo dos negócios, ${ }^{223}$ concretizadas pelo casamento endogâmico. Para Mauro, os mercadores médios normalmente importavam e exportavam várias mercadorias, concentrados no comércio dos produtos do Oriente, tecidos e seda. Com o tempo, alguns foram deixando o trato, emprestando dinheiro a juros, dedicando-se à gestão do patrimônio e das finanças, com poder e influência internacional $^{224}$.

Para James C. Boyajian, os mercadores cristãos-novos formavam uma elite que dominou a Rota do Cabo e o comércio do Oriente, a partir dos fins do século XVI, e também investiu na colonização do Brasil e na empresa açucareira, onde fizeram fortuna. Os cabedais se multiplicaram nas mãos de poucas famílias que se tornaram banqueiros e foram os financiadores da Coroa

\footnotetext{
1961, p. $19-20$

${ }^{223}$ Frédéric Mauro. Marchands et Marchands-Banquiers Portugais au XVIII Siècle, Coimbra, ${ }^{224}$ Idem, p. 25-27.
} 
espanhola na década de 1620, socorrendo-a com grandes empréstimos. Dominavam o trato e os asientos, configurados em redes de comércio familiares estendidas, dado o casamento entre primos e primas, tios e sobrinhas, o que reforçava as relações de parentesco e recombinavam o capital nas casas comerciais e nas atividades bancárias. Os casamentos se davam entre os membros dispersos pela diáspora e, muitas vezes, as diferentes gerações em Lisboa foram criadas juntas, com os mesmos valores, assistiram aos mesmos casamentos e os laços formados ao longo dos anos iam se solidificando, transformando-se em colaboração nos negócios e eventualmente em novas alianças de casamentos entre as famílias. ${ }^{225}$

David Grant Smith, em seu trabalho sobre as redes de comércio, ressalta que a classificação dos mercadores é bastante subjetiva, pois somos informados qual foi o nível que o mercador atingiu na hierarquia econômica e social, mas não como se deu sua trajetória de ascensão. Apesar das ressalvas, Smith afirma que a classificação dos mercadores é útil visto que se baseia na riqueza destes e em sua diversidade de interesses.

Essa classificação muitas vezes leva em conta apenas o ápice da hierarquia mercantil e desconsidera a origem do comerciante, por vezes simples, como aprendiz, e sua eventual evolução na carreira mercantil. Para Grant Smith, nem sempre a ascensão econômica do mercador era fruto do seu empenho pessoal no trato, visto que o casamento também era uma estratégia de ascensão econômica e social que se dava dentro ou fora do grupo mercantil a que se pertencia. ${ }^{226}$

225 James C. Boyajian. Portuguese Bankers at the Court of Spain 1626-1650, op. cit; Portuguese Traders in Asia under the Habsburgs 1580-1640, op. cit.

${ }^{226}$ David Grant Smith. The Mercantile Class, op. cit. p.72-73. 
Daniel Strum classifica os agentes das redes de comércio em maiores e menores. Os maiores eram os de grandes cabedais e fixos, na maioria judeus/cristãos-novos. ${ }^{227}$ Cada tipo apresentava uma correspondência diferente com respeito às relações de parentesco e etnicidade ligando o mercador a seu agente. As associações com esses agentes envolviam somas mais vultosas, maior autonomia e responsabilidade.

Nosso foco de estudo está no clã dos Dias de Milão que aparece citado em diversos trabalhos como família riquíssima, com uma rede de comércio em escala global, com interesses nos mais rentáveis negócios da época. Hermann Pris Salomon em Portrait of a New Christian, Fernão Álvares Melo (1569-1632) centra a sua atenção na repressão inquisitorial, ${ }^{228}$ ao abordar a trajetória do cristão-novo Fernão Álvares Melo nos cárceres da Inquisição em Lisboa, relatando como o acusado de judaizante conseguiu esconder a fé hebreia e não denunciar muitos dos seguidores da lei de Moisés, apesar dos tormentos a que foi submetido. Foram seus companheiros nas Escolas Gerais integrantes da família Dias de Milão. Salomon também narra a trajetória da família aprisionada acusada de judaizante nas mãos da Inquisição. Fundamentado em vasta pesquisa, descreve detalhadamente o percurso da família no cárcere e fora dele, permitindo que conheçamos e identifiquemos muitas das relações de parentesco e a rede de comércio desse poderoso clã cristão-novo.

Gonsalves de Mello, ao tratar dessas redes de comércio, traz os Dias de Milão, os Fidalgos e os Anjo como representantes dessa forma de organização comercial. Para ele, as redes de comércio baseavam-se em relações familiares

${ }^{227}$ Daniel Strum. The Portuguese Jews and New Christians in the Sugar Trade: op. cit.

${ }^{228}$ Herman Pris Salomon. Portrait of a New Christian, Fernão Álvares Melo (1569-1532). Paris: Fundação Calouste Gulbekian; Centro Cultural Português, 1982. 
e parentais que não seriam formas de organização exclusiva dos cristãos novos, mas comum aos comerciantes do século XVI e XVII. ${ }^{229}$

O trabalho de Leonor Freire Costa ${ }^{230}$ traz muitas informações sobre as atividades econômicas dos Milão, visto que eles estão entre os principais grupos mercadores cristãos-novos citados pela autora. Os dados apresentados, por meio dos minuciosos levantamentos de fretes, contratos de carregamentos, carregadores e seus correspondentes em Pernambuco e Bahia, feitos por Henrique, seus filhos, sobrinhos, genros e outros parentes no negócio do açúcar. A análise desses dados e a relação e interconexão entre eles e outros anteriormente levantados são fundamentais para que se possa estabelecer a rede dos Milão, sua extensão e dinâmica. Nessa configuração, cada elemento da parentela ocupa uma função específica na organização familiar, para por meio de suas ações conjuntas apropriarem-se dos lucros advindos delas. As práticas sociais desses cristãos-novos de origem castelhana visam o reforço do poder de influência familiar através de uma estratégia que é partilhada por todos os seus membros.

A análise das transações comerciais realizadas pelos membros da família Dias de Milão, seus agentes, feitores e correspondentes em âmbito global são uma maneira de extrairmos informações sobre o modo de vida, relações sociais e empreendimentos desse clã e de outros que mantinham estreitas relações com os Milão. Tais informações são fundamentais para que percebamos a importância das relações étnicas e religiosas nas redes e como elas se mantiveram forte mesmo com a expansão das ações mercantis com

${ }^{229}$ José Antonio Gonsalves de Mello. Gente da Nação: op. cit. p. 38-40.

${ }^{230}$ Leonor Freire Costa. O Transporte no Atlântico e a Companhia Geral do Comércio do Brasil (1580-1663), 2 vols. Op.cit. 
outros grupos não sefarditas e também identificar relações das redes com a Coroa em diferentes momentos.

O estudo da rede dos Dias de Milão é relevante porque sua atuação, dinâmica e organização e inter-relação com as demais redes são similares às redes de outros cristãos-novos membros da elite mercantil lusa, com atuação global em fins do século XVI e início do XVII. Eles se encaixavam na dinâmica do trato europeu, configurado na dinâmica das redes que eram primordialmente formadas por elementos de origem portuguesa e em virtude de suas atividades econômicas deslocavam-se e viveram suas vidas no exterior, muitas vezes, em vários lugares do mundo, nas praças onde os negócios requeriam suas presenças. Dessa forma, a trajetória estendida do clã mercantil que incluía filhos, genros, sobrinhos e netos seguia vetores importantes da atividade comercial das redes portuguesas não restritas ao triângulo conhecido Lisboa/Porto, Amsterdã, Brasil. Até 1620, os Milão tinham se fixado em Hamburgo, Londres e Rouen onde possibilidades de negócio se abriam e logo se multiplicavam. Sua atuação se deu de Goa ao México, encampando as principais atividades econômicas entre 1580 e 1630.

\section{2 A origem dos Dias de Milão}

A partir de 1550, grandes clãs cristãos-novos aparentados foram se firmando no universo mercantil, substituindo os italianos e alemães na liderança no trato e nas finanças europeias. Os mais importantes foram os 
Mendes de Brito; Ximenes de Aragão, Veiga e Rodrigues d'Évora; Teixeira/Faleiro; Azevedo e Paz; Tinoco. ${ }^{231}$

Os Dias de Milão pertenciam à elite mercantil lisboeta e integrantes do mais poderoso clã cristão-novo da segunda metade do século XVI e início do XVII: os Ximenes, Veiga e Rodrigues d'Évora. Esses sobrenomes estavam ligados a famílias espanholas que se estabeleceram em Portugal depois de 1492, quando foram expulsos de Espanha.

A origem dessa família remonta a 1480, em Castela e Aragão, período no qual os judeus passaram a ter restrições estabelecidas pelas Cortes de Toledo $^{232}$ na convivência com a comunidade cristã e suas atividades financeiras foram regulamentadas. ${ }^{233}$ Entre 1480 e 1492 houve uma forte migração de judeus em direção a Portugal que fugiam da Inquisição espanhola. A maioria dos imigrantes se estabeleceu não muito longe dos limites de Castela, ${ }^{234}$ o que fez surgir judiarias em vilas e em pequenas cidades em Portugal, ${ }^{235}$ que foram o berço de famílias cristãs-novas que dominaram o trato a partir da segunda metade do século XVI.

A união dos dois sobrenomes Ximenes e Aragão se deu pela união de Tomás Ximenes e Constança Coronel, filha de Fernão Peres Coronel, Regedor de Segóvia e secretário dos Reis Católicos. ${ }^{236}$ Tiveram sete filhos, entre os quais Rodrigo da Veiga, que foi médico de D. Manuel I, rei de Portugal, e ficou

${ }^{231}$ Leonor Freire Costa. O Transporte no Atlântico e a Companhia Geral do Comércio do Brasil (1580-1663), op. cit. p. 178.

${ }^{232}$ Haim Beinart, Los Judios en España. Madrid, Editorial Mapfre, 1992, p. 42.

${ }^{233}$ Joseph Pérez. Los Judios en España, Madrid: Marcial Pons, 2005.p. 146.

${ }^{234}$ Amador de los Rios. Historia de los judios de España y PortugaL, 1875. Disponível em: http://www.redejudiariasportugal.com/index.php/en/documentos-2/item/318-historia-de-los-judios-deespana-y-portugal. Acesso em: 1 fev.2014.

${ }^{235}$ Joseph Pérez. Los judios en España, op. cit. p. 111.

${ }^{236}$ Florbela Veiga Frade.O Trato e a Família...op. cit., p. 275. 
conhecido também como Mestre Rodrigo de Évora. Casou-se em Covilhã ${ }^{237}$, nos finais do século $X V$ ou princípios do século $X V I$, com D. Joana Nunes de Aragão.

Dessa união nasceram seis filhos e uma filha: Manuel Rodrigues de Évora (1506 - 1581) - casou com Catarina Lopes de Elvas; Isabel Rodrigues da Veiga (1508 - 1566) - casou com Duarte Ximenes de Aragão; Rodrigues de Évora de Andrade (1510 - 1575) - assinou os seus livros como André Rodrigues Eborense; Simão Rodrigues de Évora; Tomás Rodrigues da Veiga (1513-1579); António Rodrigues de Évora - faleceu em 1554. ${ }^{238}$

Tomás Ximenes de Aragão nasceu em Lisboa no ano de 1534 e foi o maior contratador de pimenta de seu tempo, controlando o tráfico desta especiaria, junto com os parentes d’Elvas, e se tornou um homem riquíssimo. Em 1566, doou para a cidade de Lisboa a quantia de $100.000 \$ 00$ para amenizar a fome da população que enfrentava uma séria crise de abastecimento naquele ano. ${ }^{239}$ Fidalgo Cavaleiro da Casa Real faleceu depois de 1593. Casou-se em Lisboa, com D. Teresa Vasques d'Elvas, filha de Antônio Fernando d'Elvas, tesoureiro da infanta D. Maria, filha do Rei D. Manuel.

O negócio com a pimenta foi enriquecendo os irmãos Ximenes de Aragão. Fernão estabeleceu-se em Antuérpia e acabou indo para Florença por desavenças com o duque de Alba, em 1588. O poderio econômico e social dos Ximenes de Aragão foi crescendo de maneira que o Papa Certo $V$ concedeu

${ }^{237}$ Desde o século XII Covilhã acolheu a maior e mais importante comunidade judaica da região da Serra da Estrela e uma das maiores e mais expressivas de Portugal. No final do século XV tinha pelo menos três núcleos judeus. Maria José Ferro Tavares. Los Judios. op. vit. p. 154.

p. 12.

${ }^{238}$ Joseph Ben Brith. Dye Odissee der Henrique Familie. Frankfurt au Main: Peter Lang, 2001.

${ }^{239}$ Florbela Veiga Frade.O Trato e a Família...op.cit. p. 277. 
um breve de motu próprio declarando os Ximenes cristãos-velhos e dando-lhes suas armas, proibindo que se indagasse sobre suas origens judaicas, e Fernão veio a falecer em Florença em 1600. Rui Ximenes de Aragão faleceu em Antuérpia em 1581. André Ximenes de Aragão faleceu em 1619 tendo sido Fidalgo Cavaleiro da Casa Real e Cavaleiro da Ordem de Cristo em $1596 .{ }^{240}$ Essa família era considerada os "Fugger de Portugal" dada sua importância na economia ibérica e europeia. ${ }^{241}$

Duarte Ximenes de Aragão casou-se com Isabel Rodrigues da Veiga, filha do Dr. Tomás Rodrigues da Veiga, e foram pais de quatro filhos que se tornariam expoentes da elite mercantil lusa. Duarte era destacado mercador, tendo participação no consórcio Affaitadi e Mendes ${ }^{242}$ nos contratos da pimenta que lideravam o comércio dessa especiaria no Oriente na primeira metade do século $\mathrm{XVI}^{243}$. Entre seus filhos estavam Jorge Rodrigues que se casou com Guiomar Gomes, e foram pais de Francisco Rodrigues Milão, que desposou Beatriz Gomes, e deu à luz a Guiomar Gomes, nascida em Covilhã, local que está localizado a 20 quilômetros de Belmonte e a 30 quilômetros da Guarda.

Guiomar contraiu núpcias com Henrique Dias de Cáceres, mais tarde, Henrique Dias de Milão. A esposa de Henrique, Guiomar, era descendente direta da elite mercantil cristã-nova do trato português no século $X V I^{244}$ e o casamento seu irmão Diogo Gomes uniu sua família aos riquíssimos Solis, como também o de sua sobrinha Beatriz Gomes, filha de Diogo e Guiomar Solis a André Faleiros. ${ }^{245}$

\footnotetext{
${ }^{240}$ Mayer Kaserling. História dos judeus portugueses, op. cit, p. 46-52.

${ }^{241}$ James C. Boiajyan. Portuguese Bankers, op.cit. p. 49.

${ }^{242}$ A. A. Marques de Almeida. Capitais e capitalistas, op.cit, p. 75-79.

${ }^{243}$ A. A. Marques de Almeida. O zangão e o mel.... op. cit. p. 32.

${ }^{244}$ Florbela Veiga Frade. O trato e a família, op.cit, p. 345.

${ }^{245}$ ANTT. Inquisição de Lisboa. Processo 14409.
} 
Foram seus irmãos Jorge Rodrigues, Fernão Nunes Ximenes (15251600) e Rui Nunes Ximenes que se casaram com as primas Ana Lopes e Graça Rodrigues d'Évora, respectivamente e transferiram-se para Antuérpia.

Os dois irmãos de Guiomar Fernão e Ruy Ximenes fundaram em 1571 a mais importante casa comercial na cidade do Escalda, comandada por Fernão. Os irmãos Ximenes eram dos mais assíduos que socorriam a Coroa com recursos financeiros por meio de empréstimos. Com o falecimento de Ruy Nunes Ximenes, a escrituração contábil mostra que a casa comercial passou a se chamar Fernão Ximenes e descendentes de Rui Nunes Ximenes. ${ }^{246}$

Por volta de 1570, muitas famílias cristãs-novas já haviam assegurado posição de destaque no trato e eram expoentes da elite mercantil lusa.

\subsubsection{Henrique Dias de Milão}

Henrique Dias de Milão nasceu em Santa Comba Dão em 1528. Seus avós maternos eram o comerciante Fernão de Cáceres, que teria vindo de

Cáceres na Espanha e casado com Isabel de Santiago. ${ }^{247}$ A filha Leonor de Cáceres casou-se com Antonio Lopes e tiveram os seguintes filhos: Henrique Dias de Cáceres; Francisco Lopes, que morreu nas Índias: Antonio Dias Cáceres casado Catalina de Leon de la Cueva, que morreu no México. Guiomar Manuel foi casada com Pedro Rodrigues Cohen e seu filho Henriques Rodrigues Cohen tornou-se um médico conhecido em Hamburgo e casou-se com Leonor, a filha de Henrique e Guiomar Gomes. A irmã Branca casou-se com seu primo Gabriel Gomes. A terceira irmã, também chamada Beatriz, se casou com o primo Anrique Gomes.

\footnotetext{
${ }^{246}$ A. A. Marques de Almeida. Capitais e Capitalistas, op. cit, p. 80-86.

${ }^{247}$ ANTT. Inquisição de Lisboa. Processo 6677.
} 
Como era comum na época, os meninos e jovens eram mandados para casa de familiares ou aparentados para terem iniciação nos negócios do trato $^{248}$ e Henrique foi mandado a Lisboa com 13 anos com esse objetivo.

Em meados da centúria, o comércio com o Oriente prosperava e muitos cristãos-novos dirigiram-se para as Índias. Henrique Dias de Milão foi para o Índico junto com seus irmãos, Francisco Lopes de Cáceres, Gomes Milão, Gaspar Milão e Antonio de Cáceres ${ }^{249}$ e seu sogro Francisco Rodrigues Milão. Francisco de Milão e seus filhos lutavam no Oriente nas armadas portuguesas. O patriarca dos Milão (1510-?) e Gaspar morreram na defesa de interesses lusos na Índia, enquanto Gomes Milão perdeu a vida numa batalha naval nas proximidades de Cabo Verde. ${ }^{250} \mathrm{Em} 1585$, o rei Felipe I nobilitou a família em virtude dos feitos militares heroicos dos Milão, pelos serviços e sacrifícios prestados à Coroa. ${ }^{251}$ Francisco Milão (filho) era mercador e morava em Goa e aí se casou com Antônia Dourada, que morreu em Cochim. ${ }^{252}$

Embora não tenhamos registro do período no qual Henrique esteve no Oriente, podemos inferir que tenha sido na década de 1580, entre 1584 e 1589, calculando esse período pelo intervalo de seis anos entre o nascimento de Paulo de Milão (1584) e da caçula Isabel Santiago Henriques de Milão (1590).

Henrique Dias de Milão fez fortuna no comércio no Oriente na década de 1580. Retornou a Lisboa e com a morte do sogro e dos cunhados, agregou o sobrenome Milão ao seu e se tornou o chefe da família. No Oriente tinham

${ }^{248}$ James C. Boiajyan. Portuguese Trade in Asia, op.cit, p. 6.

${ }^{249}$ Idem, p. 234

250 ANTT. Inquisição de Lisboa, processo 12305. Henrique declarou ao Santo Ofício que seu sogro, Francisco Rodrigues Milão, andou pelas Índias por muito tempo, junto com seus filhos Gomes Rodrigues de Milão e Gaspar Milão, este falecendo na Índia. ANTT. Inqusição de Lisboa. Processo 6677. As informações sobre Gaspar são contraditórias na genealogia. op.cit, p. 45

${ }^{251}$ Herman Pris Salomon. Portrait of a New Christian, Fernão Álvares Melo (1569-1532),

\footnotetext{
${ }^{252}$ ANTT. Inquisição de Lisboa, processo 6677.
} 
grandes negócios com a pimenta e outras especiarias ${ }^{253}$, associados aos Ximenes de Aragão, seus parentes. ${ }^{254}$ Gaspar vivia em Lisboa, tinha negócios em Cabo Verde de onde tirava seu sustento, mais especificamente de sua fazenda em Cabo Verde. ${ }^{255}$

Antonio Dias de Cáceres, irmão de Henrique, nasceu em Santa Comba Dão, em 1541 e chegou a Lisboa por volta de 1550 para que fosse treinado no trato. Ficou alojado primeiramente na casa de um nobre e depois com parentes, onde se tornou aprendiz e se dedicou às coisas do mar, saindo nas embarcações que iam para fora do Reino. ${ }^{256}$ Logo esteve a serviço nas embarcações com Gaspar da Cunha e também serviu à Armada espanhola. ${ }^{257}$

Em 1586, casou-se em Lisboa com uma viúva, Catalina de La Cueva sobrinha de Luis de Carvajal y de La Cueva, e foram para o México. Estabeleceram-se no Novo Mundo e Cáceres tornou-se grande comerciante como sócio de seu concunhado, o também cristão-novo português Jorge de Almeida, ligado aos negócios do ouro e da prata, ${ }^{258}$ em especial nas minas de Tasco. ${ }^{259}$ Luis Carvajal y de La Cuenca nasceu em Portugal, de família cristãnova ligada ao tráfico negreiro na Guiné e com fortes laços com a Coroa espanhola, viveu em Cabo Verde por treze anos, antes de ter se fixado no México, onde se tornou governador do Estado de Nuevo León, e fundou a atual cidade estadunidense de Monterrey. ${ }^{260}$ A prata tornou-se a moeda de troca no

\footnotetext{
${ }^{253}$ James C. Boiajyan. Portuguese Trade, op.cit. p. 276

${ }^{254}$ James C. Boiajyan. Portuguese Bankers, op.cit. p. 68; 72; 76.

${ }^{255}$ ANTT. Inquisição de Lisboa. Processo 14409.

${ }^{256}$ ANTT. Inquisição de Lisboa, Processo 6677.

${ }^{257}$ Herman Pris Salomon, Portrait of a New Christian, op.cit, p.47

258 ANTT. Inquisição de Lisboa. Processo 6677.

${ }^{259}$ Alfonso Toro. La familia Carvajal: Estudio histórico sobre los Judios y la Inquisición de la Nueva España en el siglo XVI, Cidade do México: Patria, 1944, p. 123.

${ }^{260}$ Idem, p. 117-125.
} 
Oriente, e a América Espanhola respondia por 100\% da produção mundial aurífera e $85 \%$ da prata.

Em 1580, ano em que ocorreu a união das Coroas Ibéricas, a disponibilidade e a circulação da prata americana eram significativas para os portugueses por sua utilização no comércio nas Índias. Naquele momento a produção da prata na América espanhola estava no auge, o que contribuiu para que a circulação do precioso metal tivesse um importante papel no ativo comércio entre lusos e castelhanos. ${ }^{261} \mathrm{~A}$ exploração da prata era feita sob a concessão de monopólio real e os que tinham a concessão para extraí-la eram membros da mais poderosa elite espanhola. ${ }^{262}$

Nos anos de 1590, a Inquisição espanhola prendeu a família Carvajal praticamente inteira, inclusive sua mulher e filha, Leonor, acusando-as de judaizantes e crimes de judaísmo. Diante da perspectiva de ser preso, Cáceres fugiu para o Oriente em seu próprio navio e participou intensamente durante os três anos das trocas entre México, Portugal, Espanha, África e Oriente, retornando ao México depois desse período. ${ }^{263}$ Entre 1595 e 1597, associou-se ao cristão-novo Manoel Gil da Guarda, também do México, movimentando e realizando negócios de grande vulto. ${ }^{264}$ Catalina morreu na fogueira em $1596 \mathrm{e}$ Leonor foi reconciliada na fé em 1601.

Em 1606, Antonio encontrava-se em Lisboa, hospedado na casa do irmão Henrique, quando a família foi presa pelo Santo Ofício. Ele vinha de Londres, onde permaneceu por mais de um ano, e seguiria para as Índias de

${ }^{261}$ Stuart B. Schwartz. Prata, açúcar e escravos: de como o império restaurou Portugal. Tempo, 2008, vol.12, $\mathrm{n}^{\mathrm{o}} .24, \mathrm{p} .201-223$.

262 Joaquim Romero Magalhães

${ }^{263}$ Herman Pris Salomon, op. cit., p.45

${ }^{264}$ James C. Boyajian. Portuguese Bankers in Asia Trade, op. cit p. 203-210. 
Castela, via Angola, onde trataria de negócios relativos a escravos. ${ }^{265} \mathrm{Na}$ capital inglesa, seu correspondente era Gabriel Fernandes, cristão-novo, mercador, filho do falecido também mercador Luís Fernandes, e seu irmão Duarte Fernandes, então com 14 anos, que aprendia as coisas do trato. ${ }^{266}$ Paulo de Milão, filho de Henrique, que estivera no Brasil, acompanhou o tio Antonio Dias de Cáceres à Inglaterra. ${ }^{267}$

Pela atividade açucareira em expansão, as capitanias do norte da colônia portuguesa na América despontavam como região de grande possibilidade de comércio. Os preços do açúcar apresentavam uma forte tendência ascendente, com o preço médio do açúcar branco e mascavo subindo mais de $40 \%$ entre 1572 a 1579. Em Lisboa e Londres, os preços parecem ter subido acentuadamente entre 1578 e $1582 .{ }^{268}$ Essa tendência de alta permaneceria, com algumas baixas eventuais, até a década de $1630 .{ }^{269}$ Esses números mostram que o negócio do açúcar tomava vulto em Pernambuco e Bahia, atraindo capitais cristãos-novos que passaram a ser investidos na empresa açucareira.

Henrique foi o líder da rede comercial que teve negócios de grande vulto com o comércio colonial, apoiando-se diretamente nos filhos e genros, além de sobrinhos e outros sefardis com os quais havia intensa troca. Em 1592 o filho mais velho de Henrique, Manuel Cardoso de Milão fixou-se em Olinda, onde junto com o cunhado Manuel de Matos, tornaram-se expoentes na exportação do açúcar $^{270}$. Teve nove filhos, a saber: Manuel Cardoso de Milão (1571);

\footnotetext{
265 ANTT. Inquisição de Lisboa. Processo 2499.

ANTT. Inquisição de Lisboa. Processo 3333.

267 ANTT. Inquisição de Lisboa. Processo 3467.

${ }^{268}$ Stuart Schwartz. Segredos Internos, op. cit, p. 152.

${ }^{269}$ Vera Ferlini. op. cit., p. 60-61.

${ }^{270}$ James C. Boyajian. Portuguese Bankers, op. cit. p. 93;168.
} 
Beatriz Henriques de Milão (1573); Gomes Rodrigues de Milão (1574); Fernão Lopes de Milão (1575); Leonor Henriques de Milão (1577); Antonio Dias de Milão (1582); Ana de Milão (1584); Paulo de Milão (1584); Isabel Santiago Henriques de Milão (1590).

\subsubsection{O casamento endogâmico}

Um dos pilares das redes de comércio cristãs-novas foi o casamento endogâmico, bastante frequente entre primos coirmãos, como estratégia de manutenção de patrimônio e evitar o alargamento das redes. Os casamentos eram arranjados e também como meio de unir capitais, sendo que os dotes de casamento podiam ser de alguns mil cruzados, na verdade, pequenas fortunas. ${ }^{271}$ As alianças conjugais, negociadas e acertadas entre os mais poderosos da mercancia lusa, garantiam regalias adquiridas, e em muitos casos alargá-las, contribuindo para proporcionar aos mais jovens a estabilidade sempre desejada, e a certeza da transmissão dos privilégios e das fortunas acumuladas. Nessas circunstâncias, o matrimônio funcionava como um "contrato" ou uma "aliança" entre grupos. ${ }^{272}$ Mantinha-se, assim, a identidade cultural, racial e religiosa de uma minoria. ${ }^{273}$

O matrimônio era colocado no âmbito dos interesses do grupo e os indivíduos serviam aos interesses da família que nunca perdiam de vista nem cediam totalmente os seus direitos sobre as escolhas e as funções produtivas,

\footnotetext{
${ }^{271}$ Florbela Veiga Frade. O Trato e a Família, op.cit. p. 348-349.

${ }^{272}$ Jonathan I. Israel. Dutch Republic... p. 163-170.

${ }^{273}$ ANTT. Inquisição de Lisboa. Processo 3333.
} 
reprodutivas e sexuais dos cônjuges e dos filhos que se casavam. ${ }^{274}$ Essa postura se explica pela vontade da não dispersão dos bens, e ainda mais pela segurança conferida pelo casamento com alguém que professasse a mesma fé, quando o credo católico se opunha a qualquer outro. Os filhos de Henrique Milão se casaram com cristãos-novos da elite sefardita. Os irmãos Beatriz e Henrique Rodrigues, sobrinhos de Henrique, casaram-se com Gomes Rodrigues de Milão e sua irmã Leonor. Gomes, filho de Henrique, rebelou-se contra a união conjugal que lhe era imposta e que atendia aos interesses da família. O seu testemunho, em sua defesa no processo que foi acusado pela Inquisição de Lisboa, declarou que a denúncia contra ele era fruto do ódio que tinham contra ele, visto que desejava se casar com a filha do livreiro, e que a família não concordava. Seu casamento com a prima-irmã Beatriz Henriques já estava acertado e os irmãos ameaçavam matar a moça na qual tinha interesse, caso ele insistisse na ideia do matrimônio, conforme podemos verificar:

"O seu pai, sua mãe e irmãos Ihe queriam todos mal por ele querer casar contra suas vontades com uma moça de baixa sorte e muito diferente deles. E era tanta a sua vontade que escreveu a Fernão Lopes e a Manuel Cardoso que estavam no Brasil, seus irmãos e disseram que era melhor matarem a moça porque estavam a tratar do seu casamento com uma parenta moça, que não devia fazer tal desonra, ao casar com Bárbara Freire, filha de [do livreiro] Manuel Freire. São suspeitos porque Ihe querem mal por ele querer o casamento que estavam a tratar com sua prima Beatriz Rodrigues, a qual também é suspeita pela mesma razão. Se ele consentiu o casamento com sua 245.

${ }^{274}$ Daniel Strum. The Portuguese Jews and New Christians in the Sugar Trade, op. cit. p. 237- 
prima, foi por medo de fazerem o que tinham escrito na carta que enviaram para o Brasil.."275

O casamento da filha mais velha de Henrique Beatriz, em 1605, então com 33 anos com Álvaro Dinis, judeu assumido em Hamburgo, uniu a família Milão com os Dinis, originária do Porto, notadamente ligada à grande mercancia e riquíssimos, ${ }^{276}$ sendo o pai de Álvaro, Filipe Dinis, um dos grandes investidores nos contratos da pimenta. ${ }^{277}$

O nível de entendimento entre as famílias era complexo e incluía a negociação do dote, podendo haver intermediação de parentes próximos, como o ocorrido com Vicente Furtado que permaneceu por dois meses em Hamburgo com Álvaro Dinis tratando do casamento de sua prima Beatriz, a filha mais velha de Henrique e Guiomar, com o primo Álvaro, filho de Francisca de Palácios, casada com Duarte Furtado, que deveria acontecer em Hamburgo, e não em Lisboa. Seu retorno a capital do reino deu-se em outubro de $1605 .{ }^{278}$

Dinis foi um dos primeiros cristãos-novos a migrar para Hamburgo onde se assumiu judeu, por volta de 1600 . Dinis não era aparentado dos Milão, mas descendente de judeus estabelecidos na Península Ibérica, em Castela, desde o século XII. No século XIII, Jahia el Negro Ibn Ya'isch tornou-se conselheiro de Afonso I e era o rabino chefe de Portugal. Daí em diante, a família continuou muito próxima à Coroa portuguesa, com grande fortuna, e também à de Castela. Seus tios avós já receberam sobrenomes cristãos, Pero Francisco de Palácios e Gabriel Furtado. Seu pai era filho de Davi Marco, conhecido como Selomon Jachia e Filipe de Nis ou Dinis (1530-1599). Filipe Dinis morou em

\footnotetext{
275 ANTT. Inquisição de Lisboa, Processo 2499.

${ }^{276}$ Joseph Ben Brith. Dye Odissee der Henrique Familie. Frankfurt au Main: Peter Lang, 2001.

277 James C. Boyajian. Portuguese Trade in Asia under the Habsburgs, op.cit, p. 133; 202.

${ }^{278}$ ANTT. Inquisição de Lisboa, Processo 7840.
} 
São Tomé, Colônia, Antuérpia (por volta de 1570), Hamburgo e faleceu em Veneza. Seus parentes estariam muito ligados aos judeus e cristãos-novos em Veneza, Londres e com ramificações no Império Otomano. ${ }^{279}$ Ele aparece na documentação ligado a Simon Ruiz, Duarte $X_{i m e n e z}{ }^{280}$ e a outros grandes mercadores do negócio da pimenta em Antuérpia, muitas vezes com ramificações na França (Rouen, Nantes, La Rochelle) conforme a farta correspondência disponibilizada por J. Gentil da Silva em Merchandises et Finances Lettres de Lisbonne (1563-1578). ${ }^{281}$

\subsection{A mobilidade das redes e os Perdões Gerais}

Uma das características das redes foi a itinerância dos seus membros, com idas e vindas a Portugal e às principais praças de comércio da época, sendo essa mobilidade muito bem apontada por Strum. ${ }^{282}$

No entanto, a permissão de saída de cristãos-novos livres de qualquer impedimento do Reino se deu por períodos muito curtos no século XVI e início do XVII. As restrições impostas a eles estavam diretamente ligadas tanto com os temores da Inquisição que pudessem se assumir judeus fora do Reino como da Coroa de que, ao saírem, levassem com eles seus cabedais, ou parte deles

\footnotetext{
${ }^{279}$ José Maria Abecassis. Genealogia Hebraica: Portugal, e Gibraltar, séc. XVII-XX.Lisboa: José Maria Abecassis, 1990-1991.V 2. p. 122-134.

${ }^{280}$ James C. Boyajian. Portuguese Trade in Asia under The Habsburgs, op.cit, p. 185-188.

${ }^{281}$ J. Gentil da Silva em Marchandises et Finances Lettres de Lisbonne (1563-1578). T III. Paris: SEVPEN, 1961. p. 26; 112-14; 132-134; 152-154;

${ }^{282}$ Daniel Strum. The Portuguese Jews and New Christians in the Sugar Trade, op.cit, p. 235; 356.
} 
e que contribuíssem para despovoar o Reino, que enfrentava problemas nesse sentido. $^{283}$

Para Florbela Veiga Frade, ${ }^{284}$ desde a conversão os cristãos-novos não podiam deixar o Reino sem autorização real. Em 1507, D. Manuel permitiu que os cristãos-novos deixassem o Reino sem necessidade de autorização régia e indicava que os recém-conversos não deveriam ser discriminados nem segregados, devendo ser tratados como cristãos-velhos. Em 1524, D. João III acrescentou entre as medidas referentes aos cristãos-novos que sua saída do Reino deveria ser feita exclusivamente em embacarcações portuguesas. ${ }^{285}$

A Inquisição foi criada por uma bula papal em dezembro de 1531 e entrou em vigor em março de 1532. Uma determinação real explicitava que nos próximos três anos os cristãos-novos ficariam impedidos de sair do Reino, inclusive com seus bens. Os que fossem apanhados fugindo, teriam seus bens confiscados e sofreriam penas; os que os transportavam, como os capitães dos navios, podiam ser condenados à morte pela pelo feito. Para cada saída era necessária permissão real e para obtê-la pagava-se 500 cruzados de fiança, um valor alto para a época.

Em 1535, foi obtido o primeiro Perdão Geral em troca do pagamento de 5.000 ducados. Assim, foram libertados os que estavam nos cárceres da Inquisição, proibidas inquirições e o confisco de bens dos cristãos-novos, provavelmente com validade de um ano. ${ }^{286}$ Em 1536, o papa Paulo III instituiu a

${ }^{283}$ Jonathan.I. Israel, Spain and the Dutch Sephardim 1609-1660. Studia Rosenthaliana 12, no . 1 (1978): p.1-61.

${ }^{284}$ Florbela Veiga Frade. Otrato e a família, op. cit, p. 61 -65.

${ }^{285}$ Meyer Kayserling. História dos judeus em Portugal, São Paulo: Pioneira, 1971, p. 147.

${ }^{286}$ Florbela Veiga Frade. O trato e a família, op. cit, p. 67- 73. 
Inquisição em Portugal, ${ }^{287}$ o que teve reflexos no controle na saída dos cristãos-novos de Portugal.

Em 1567, na regência de D. Henrique foi proibida a saída de cristãosnovos para as Índias, Guiné e Brasil, obrigando, assim, aos comerciantes com interesses na Rota do Cabo a desembolsar muito dinheiro pela ida de seus associados e representantes a locais para aonde precisavam se deslocar. Em seguida, proibiu-se que os conversos deixassem qualquer dos domínios portugueses, ${ }^{288}$ e também foi interditada a venda de seus bens. Os que saíam tinham que pagar fiança e retornar a Portugal dentro de um ano, caso não o fizesssem, perdiam a fazenda, podendo ser punidos com cinco anos de degredo no Brasil, além de os denunciantes se apossarem da metade dos bens do acusado.

Em 1577, com os cofres reais esvaziados e a Coroa necessitando de dinheiro rapidamente, foi solicitado aos cristãos-novos um pagamento de 225 mil cruzados, dinheiro que foi usado na montagem da expedição militar liderada por D. Sebastião que resultou na batalha de Álcacer-Quibir, no norte da África. ${ }^{289} \mathrm{O}$ pagamento desse montante acabou tendo o efeito de um Perdão Geral, ${ }^{290} \mathrm{com}$ a soltura dos presos pelo Santo Ofício e a promessa de que não haveria confisco de bens nos dez anos vindouros. ${ }^{291}$ As negociações foram conduzidas por Manuel Duarte, Henrique Simões e Álvaro Furtado, ${ }^{292}$ este era tio de Vicente Furtado, todos comerciantes de grosso trato ligados ao comércio

\footnotetext{
${ }^{287}$ Maria José Ferro Tavares. Los Judios. op.cit., p. 354.

${ }^{288}$ Daniel Strum. The Portuguese Jews and New Christians in the Sugar Trade, op.cit. 163; 165.
} 
do Oriente, ligado a Henrique Dias de Milão, que foi preso na tentativa de fuga, junto com a família.

As condições acordadas, no entanto, não foram cumpridas. Em 1579, o Inquisidor Geral anulou o perdão e mandou restituir o dinheiro aos pagantes, o que não acontceceu. Segundo Florbela Frade, em 1578, pouco antes de partir para Alcácer-Quibir, D. Sebastião escreveu aos cônsules da Nação Portuguesa, em Antuérpia, agradecendo a cooperação dos mercadores cristãos-novos no empreendimento militar no norte da África. ${ }^{293}$

\subsubsection{Os Perdões Gerais}

Um dos maiores temores dos cristãos-novos era o confisco de bens promovido pela Inquisição quando da prisão dos cristãos-novos, o que acontecia rotineiramente aos que era presos ele vados aos carceres da Inquisição. Em virtude disso, e do recrudescimento da ação do Santo Ofício, desde 1591, proeminentes cristãos-novos passaram a negociar a concessão de um novo Perdão Geral. ${ }^{294}$

A Coroa espanhola encontrava-se novamente às vésperas de uma nova bancarrota que se concretizou em 1607, ${ }^{295}$ estando, assim, muito endividada junto a credores italianos. ${ }^{296} \mathrm{Em} 1598$, os cristãos-novos ofereceram à Coroa 675 mil cruzados e um empréstimo no valor de 500 mil ducados, sem juros, que se destinaria às embaracações que tinham como destino as Índias e que deveria ser pago em pimenta. Nesse ano acredita-se que o déficit do tesouro

${ }^{293}$ Florbela Veiga Frade. O Trato e a Família... op. cit. p.135.

${ }^{294}$ Antonio Borges Coelho. Política e Fé. op. cit. p. 131-134. op. cit, p. 212.

295 A anterior ocorreu em 1596. James C. Boyajian. Portuguese Bankers in the Court of Spain,

\footnotetext{
${ }^{296}$ Idem, p. 213.
} 
espanhol era cerca de 1,6 milhões de ducados e que todas as rendas da Coroa estavam hipotecadas. $^{297}$

Em 1600, um grupo de importantes sefarditas lisboetas reuniu-se e escolheu Rodrigo Andrade e Jorge Gomes Solis considerados, segundo a documentação da época, como, "dos de los homens de la nacion más ricos y honestos“, 298 para que fossem a Madri levar cerca de 200 mil cruzados para tentar buscar o Perdão Geral aos cristãos-novos, nas difíceis negociações que ocorriam com a Coroa espanhola e a Igreja. ${ }^{299}$ Em 1601, com a entrega de 200 mil cruzados, ${ }^{300}$ os cristãos-novos foram autorizados a sair sem licença do Reino.

Rodrigo de Andrade, da família Rodrigues d'Evora, era casado com Ana de Milão, irmã de Guiomar Gomes. Foi asientista e destaque na alta mercancia, com negócios em Antuérpia, Brasil, África e Oriente, ${ }^{301}$ com interesses em Flandres, e estava em Valladolid em 1602, tratando de negócios. ${ }^{302} \mathrm{O}$ companheiro de Rodrigo Andrade, Jorge Gomes Solis, filho de Duarte Gomes Solis e sogro de Antonio Fernandes d'Elvas - que se tornaria o maior asientista de sua época, além de contratador de escravos -, era representante de uma das mais importantes casas comerciais portuguesas, sendo arrendatário das alfândegas do reino, financiador dos asientos, associado a diversos negócios e também proeminente banqueiro de Lisboa. Durante as negociações do Perdão

297 Ana Hutz. Redes comerciais cristãs novas no Brasil durante o reinado de Filipe III. Disponível em: <http://cihe.fflch.usp.br/sites/cihe.fflch.usp.br/files/Ana_Hutz.pdf〉. Acesso em 14 fev. 2014.

${ }^{298}$ Costa Porto. Os cinco primeiros engenhos pernambucanos. In: Revista do Museu do Açúcar. $\mathrm{n}^{\circ}$ 2, Recife, 1969. Apud: Ana Hutz. Redes comerciais cristãs novas no Brasil durante o reinado de Filipe III. Disponível em: <http://cihe.fflch.usp.br/sites/cihe.fflch.usp.br/files/Ana_Hutz.pdf>. Acesso em: 8 set. 2013.

\footnotetext{
299 Antonio Borges Coelho. Política e fé. op. cit. p. 117.

${ }^{300}$ ANTT. Chancelaria de Filipe II. Privilégios, Livro 1, fl. 72-72v.

${ }^{301}$ ANTT. Inquisição de Lisboa, processo 1491.

302 ANTT. Inquisição de Lisboa. Processo 14409.
} 
Geral foi-lhe imposto um asiento no qual se comprometia com a construção de sete embarcações que deveria levar às Índias e trazê-las carregadas com mercadorias lá adquiridas, como a pimenta. ${ }^{303} \mathrm{~A}$ ida a Madri dos dois cristãosnovos não obteve os resultados esperados e, em 1602, provavelmente em retaliação à ação de Rodrigo de Andrade, ${ }^{304}$ sua mulher, Ana de Milão, foi levada aos cárceres da Inquisição, em Lisboa, acusada de heresia e judaísmo. ${ }^{305}$ Com intensa atividade em Antuérpia, ${ }^{306}$ já iniciara seus filhos na mercancia que lá se estabeleceram, lidando também com diamantes. Suas relações com o Papa Clemente VII o faziam respeitado na corte espanhola.

Quando soube da prisão de Ana de Milão, tentou intervir em sua soltura, pedindo ajuda diretamente ao rei Filipe II para que este usasse sua influência junto ao papa, em Roma, sem, no entanto, conseguir seu intento. ${ }^{307}$ Diante disso, em 1603, Rodrigo de Andrade deixou as negociações do Perdão Geral. Ana foi solta em janeiro de 1605 em virtude da concessão do Perdão Geral e Rodrigo faleceu nesse mesmo ano em Antuérpia. ${ }^{308}$ Ana terminou seus dias junto com a irmã Guiomar Gomes, já viúva de Henrique Dias de Milão, e alguns dos filhos do casal em Hamburgo. ${ }^{309}$

O Perdão Geral foi concedido em 1605 com a contrapartida do pagamento da fantástica soma de um milhão e setecentos mil cruzados. ${ }^{310}$ Por ele, todos os prisioneiros da Inquisição foram libertados e as sentenças

303 Ana Hutz. Redes comerciais cristãs novas no Brasil durante o reinado de Filipe III. Disponível em: <http://cihe.fflch.usp.br/sites/cihe.fflch.usp.br/files/Ana_Hutz.pdf>. Acesso em: 14 fev. 2014.

${ }^{304}$ Herman Pris Salomon. Portrait of a New Christian, op.cit. p.42

305 ANTT. Inquisição de Lisboa, Processo 14409.

${ }^{306}$ Florbela Veiga Frade. O Trato e a família. Op.cit. p. 332-345.

307 Ana Hutz. Redes comerciais cristãs novas no Brasil durante o reinado de Filipe III. . Disponível em: <http://cihe.fflch.usp.br/sites/cihe.fflch.usp.br/files/Ana_Hutz.pdf>. Acesso em: 8 set.2013.

\footnotetext{
${ }^{308}$ H.P.Salomon. The Portrait of a New Christian, op. cit. p. 49-53;.98.

${ }^{309}$ Sonia Siqueira. Inquisição e Cristãos-novos, op.cit, p. 66-97.

${ }^{310}$ ANTT. Inquisição de Lisboa, Processo 10261.
} 
proferidas, canceladas. Além disso, os crimes contra a fé foram perdoados, portanto, não sendo passíveis de serem usados como provas ou como indício para denúncia em processos de acusados no futuro. Essas medidas valeriam por um ano, depois disso, os crimes contra a fé necessariamente deveriam ser usados pela Inquisição nos indiciamentos nos processos do Santo Ofício. ${ }^{311}$

O montante acertado não chegou a ser pago integralmente, visto a discordância entre os próprios sefarditas que não formavam um grupo homogêneo e o fato de terem de conseguir cobrar os seis mil cristãos-novos arrolados como contribuintes no breve que Clemente VIII concedeu o Perdão Geral. $^{312}$

Na década de 1620, a situação do erário real era crítica. Mais uma vez, a Coroa espanhola recorreu aos cristãos-novos e desde 1622 negociava com banqueiros e mercadores de grosso trato portugueses e grandes banqueiros, liderados por Rui Dias Angel, João Nunes Saraiva, Antonio Fernandes de Elvas, Manuel Veiga de Évora, Manuel Rodrigues de Évora. ${ }^{313}$ Em 1627 foi concendido um Édito Geral que teve o efeito de um Perdão Geral, concretizado em 1629-1630 com a libertação dos cristãos-novos presos com a contrapartida do pagamento de 225 mil cruzados aos cofres reais. O Édito previa que os cristãos-novos podiam ir para as Índias e a outras partes dos domínios lusos, sem a obrigação de voltar depois de um ano, nem pagar fiança, podendo vender seus bens de raiz, juros, tenças, porém, impedidos de levar ouro e prata consigo ao embarcar. ${ }^{314}$

\footnotetext{
${ }^{311}$ João Lúcio de Azevedo. História dos cristãos-novos portugueses, p. 153-162.

${ }^{312}$ Mayer Kaserling, op. cit. p. 242.

${ }^{313}$ James C. Boyajian. Portuguese Bankers at the Court of Spain, op. cit, p. 35; 74.

${ }^{314}$ Florbela Veiga Frade. O Trato e a Família, op. cit, p. 129.
} 
Vicente Furtado foi a Londres e Hamburgo aproveitando-se do Perdão Geral de $1605 .{ }^{315}$ Vicente Furtado, primo de Álvaro Dinis, preso na fuga frustrada, mercador de grosso trato, que tinha estado em Veneza, Antuérpia e também no Brasil, ligado ao comércio do açúcar, ${ }^{316}$ que se estabelecera em Hamburgo para tratar dos negócios, ${ }^{317}$ deixou Portugal para visitar seus primos e parentes cristãos-novos em Londres e Amsterdã, visto que o corso the tomara uma carga e uma embarcação afundara numa tempestade, perdendo a carga que ia para a Inglaterra. ${ }^{318} \mathrm{Em}$ Londres ficou hospedado na casa de Gabriel Fernandes; em Roterdã, hospedou-se com Manoel Carvalho ${ }^{319}$ e em Hamburgo com Álvaro Dinis. Em Flandres, foi recebido por Anrique de Lima, judeu nascido em Braga, comerciante de pedras preciosas. ${ }^{320}$

Vicente Furtado saiu e voltou a Portugal algumas vezes de forma clandestina com o intuito de fazer negócios e rever familiares e amigos moradores no Reino ou de passagem por lá. Para Yosef Kaplan, não há dúvida que suas viagens às "terras de idolatria estavam ligadas aos seus empreendimentos comerciais". 321

As fugas eram dificeis e arriscadas, mas aconteciam, conforme mostra o trabalho de Marco Antônio Nunes da Silva, O Brasil holandês nos cadernos do

315 ANTT. Inquisição de Lisboa. Processo. 3366.

${ }^{316}$ ANTT. Inquisição de Lisboa. Processo 7840.

317 ANTT. Inquisição de Lisboa. Processo 3333.

${ }^{318}$ Idem.

${ }^{319}$ ANTT. Inquisição de Lisboa. Processo 6677.

${ }^{320}$ ANTT. Inquisição de Lisboa. Processo 12305.

${ }^{321}$ Yosef Kaplan. The Travels of Portuguese Jews from Amsterdam to the Lands of Idolatry (1644-1724). In: Yosef Kaplan (Ed.). Jews and Conversos. Studies in Society and the Inquisition. Proceedings of the Eighth World Congress of Jewish Studies held at The Hebrew University of Jerusalem, August, 16-21, 1981. Jerusalem: World Union of Jewish Studies, the Magnes Press, the Hebrew University, 1981, p. 208. 
Promotor: Inquisição de Lisboa, século XVII, ${ }^{322}$ como também cristãos-novos entravam clandestinamente no Reino. ${ }^{323}$

Os Perdões Gerais foram usados como financiadores da Coroa necessitada de recursos em diversos momentos. O Perdão Geral nem sempre foi extensivo aos cristãos-velhos encarcerados pelo Santo Ofício ${ }^{324}$. Só existem registros dessas fontes nos Livros das Chancelarias Régias de D. Filipe I e D.Filipe II, entre 1611 e 1629 há poucas autorizações de saída nesse período, a maioria de Lisboa para Madri. ${ }^{325}$ Em 1617, Gomes Rodrigues de Milão recebeu autorização para ir a Cabo Verde. Essa informação chama muito a atenção, uma vez que Gomes ter fugido do bairro penitencial sete anos antes. $^{326}$

Havia uma grande mobilidade nas redes sefarditas e constante deslocamento de seus membros, o que nos sugere que para esse segmento da sociedade portuguesa não havia muitos empecilhos para sua circulação.

\subsection{A trajetória dos Dias de Milão}

Os Milão eram uma família de ricos cristãos-novos que arrematavam os contratos régios atuando nos mais rentáveis negócios de sua época. Henrique Dias de Milão era contratador das terças juntamente com o riquíssimo Gabriel Ribeiro. Na primavera de 1605, sua filha Beatriz, então com 33 anos, tinha ido

322 Marco Antônio Nunes da Silva, O Brasil holandês nos cadernos do Promotor: Inquisição de Lisboa, século XVII. [Tese de Doutorado]. FFFLCH, USP, 2003. “'É a existência de uma rede que, em troca de um bom pagamento, proporcionava a fuga de cristãos-novos de Portugal. Como não poderia deixar de ser, esta "empresa" envolvia a colaboração de estrangeiros, quer aqueles que residiam em Lisboa e seus arredores, quer os mestres de navios." p. 74.

\footnotetext{
${ }^{323}$ Idem, p.79.

${ }^{324}$ A.A. Marques de Almeida. O Perdão... p. 86.

${ }^{325}$ Florbela Veiga Frade. O Trato e a família, op. cit., p. 220.

${ }^{326}$ ANTT. Chancelaria de D. Felipe II. Privilégios. Liv. 2. Fl. 90-90v.
} 
a Hamburgo onde se casou com Álvaro Dinis, que se assumiu judeu nessa cidade. Foi levada por seu irmão caçula, Paulo de Milão, juntamente com o empregado da casa, Francisco Barbosa, cristão-velho, no navio do irmão de Henrique, Antonio Dias de Cáceres. Ambos passaram na Ingalaterra, antes de Paulo voltar a Lisboa em 7 de outubro de $1606 .^{327}$ Diante do montante da dívida, Henrique planejou a fuga de Lisboa com a ajuda de amigos e parentes, para ir ao encontro de sua filha caçula, Beatriz, recém-casada com Álvaro Dinis, ou Samuel Jachia. ${ }^{328}$ Com ele iriam todos os filhos que estavam em Lisboa, sua mulher Guiomar e agregados que moravam em Alcântara, ficando para trás apenas Paulo de Milão, para cuidar dos negócios da família em Lisboa e Madri. ${ }^{329}$ A sua decisão estava associada a uma ameaça de prisão e sequestro de bens pela justiça civil ${ }^{330}$ e à prisão de Gabriel Ribeiro, ${ }^{331}$ seu sócio nos negócios. Ambos tinham arrematado o contrato das terças e deviam 50 mil cruzados para a Coroa. ${ }^{332}$

Os Milão tinham se mudado recentemente para Alcântara, na freguesia da Ajuda, junto às quintas de Algés e de um mosteiro por onde tinham acesso ao mar. A casa tinha uma grande área térrea e um piso superior, além de um pátio interno. Com a família Milão viviam criados e serviçais, entre eles os aparentados Francisco Barbosa, este cristão-velho, e sua irmã Violante, que foi

\footnotetext{
${ }^{327}$ ANTT. Inquisição de Lisboa 15798.

${ }^{328}$ Herman Prins Salomon. Portrait of a New Christian Fernão Álvares Melo, op.cit. p. 107108.

${ }^{329}$ ANTT. Inquisição de Lisboa 7890.

${ }^{330}$ ANTT. Inquisição de Lisboa 2523.

${ }^{331}$ Herman Prins Salomon. Portrait of a New Christian Fernão Álvares Melo, op.cit p. 107109.

${ }^{332}$ Há outra versão sobre a fuga dos Milão que envolveria um acordo secreto entre Henrique Milão e Felipe Dinis e seu filho Álvaro Dinis de Hamburgo. Álvaro Dinis teria mandado três navios diretamente do Brasil para Hamburgo e enviado as embarcações para Lisboa com produtos bálticos As autoridades portuguesas descobriram essa falcatrua dos Milão-Dinis e colocaram pessoas para vigiá-lo. Henrique sabendo disso preparou sua fuga que não deu certo. Joseph Ben Brith. Die Odysse HenriqueFamilie. Frankfurt au main: Peter Lang, 2001, p. 40-41.
} 
a acompanhante de Beatriz Henriques a Hamburgo com Paulo de Milão e Antonio de Cáceres. ${ }^{333}$ Vitória Dias era uma chinesa com mais de 50 anos, trazida por Henrique de Goa, como escrava, e alforriada há cinco ano, que continuava servindo seus antigos donos. ${ }^{334}$ António Dias de Cárceres, recentemente chegado do México, que estivera em Londres a negócios antes de aportar em Lisboa, e viera para Portugal fugindo da Inquisição espanhola. Tinha deixado a residência do irmão antes da fuga frustrada, estando em lugar desconhecido.

Eles haviam sido denunciados por Francisco Barbosa, parente distante e serviçal na casa dos Milão, que os acusou de serem judaizantes e de judaísmo. ${ }^{335}$ A fuga deixou de ser secreta e mandados de prisão foram expedidos. Mesmo tendo sido alertados pelo alcaide que estava com o mandato, pelo escrivão Madeira, por Vasco Peres Mendes que tentou atrasar a sua execução, e pelo próprio executor-mor, Manuel Gomes d’Elvas, não desistiram dela. ${ }^{336}$ Fernão Lopes Milão poucos dias antes da fuga teve acesso ao mandado por meio de António Camelo, o tesoureiro das Terças, e também teve conhecimento do segundo mandado cujo executor dos Contos era António Serrão. ${ }^{337}$

Fernão Lopes foi ter com Duarte Gomes em busca de ajuda e dinheiro para a fuga, que não quis se envolver diretamente no arriscado

${ }^{333}$ ANTT. Inquisição de Lisboa. Processo 6667.

${ }^{334}$ ANTT. Inquisição de Lisboa. Processo 3331.

${ }_{335}$ ANTT. Inquisição de Lisboa. Processo 3366.

${ }^{336}$ ANTT, Inquisição de Lisboa. Processo. 2523, fl. 139. Manuel Gomes d'Elvas foi um dos financiadores cristãos-novos do rei para o provimento da armada da Índia de 1605 no valor de 200.000 cruzados. Em 1609, com Heitor Mendes de Brito, Nuno Dias Carlos, Francisco Duarte Ximenes emprestaram ao rei 33.500 cruzados para as naus em letras de câmbio passadas em Goa. Em 1610 os mesmos proveram as naus da Índia no valor de 71.667 sendo reembolsados com o dinheiro do Perdão Geral. Cf. James Boyajian, Portuguese Trade in Asia under the Habsburgs, 1580-1640, op.cit, p. 92; Herman Prins Salomon. Portrait, op. cit., p. 94.

${ }^{337}$ ANTT, Inquisição de Lisboa, Processo. 2523. 
empreendimento, com medo de ser preso, dispondo "todo o dinheiro que lhe fosse necessário para a dita embarcação". ${ }^{338} \mathrm{Na}$ verdade, era um medo totalmente justificável, dado o rigor com que eram punidos tanto os fugitivos quanto aqueles que auxiliavam a fuga. Mas concordava, no fundo, com a viagem, tranquilizando Fernão Lopes, "dizendo que faziam bem em se irem fora dele [reino de Portugal], e que já lá houveram de estar". ${ }^{339}$

A tentativa de fuga aconteceu na noite de 28 de outubro de 1606, com alguns numa fragata e outros numa barca no Tejo, preparando-se para embarcar numa caravela que os levaria a Hamburgo. ${ }^{340}$ Estavam a bordo para acompanhá-los: Vicente Furtado, filho de Duarte Furtado e primo de Álvaro Dinis; António Mendes cristão-novo casado e morador à Cutelaria; Manuel Sanches cristão-novo, solteiro e filho de Bento Henriques (criado de Henrique Dias Milão que depois de solto pela Inquisição foi para Hamburgo); Gaspar Fernandes Penso, cristão-novo, tratante, casado com uma filha do fanqueiro Gama, morador do Pelourinho Velho; Fernão Rodrigues Penso, solteiro, filho de Fernão Rodrigues Penso que morava em Badajoz, primo de Fernão. ${ }^{341}$ Todos os envolvidos sabiam das dívidas junto a Coroa e do motivo porque fugiam do Reino. ${ }^{342}$

Segundo Marco Antônio Nunes da Silva, a família Milão foi um dos raros casos que encontramos onde a Inquisição conseguiu impedir a fuga. $^{343}$ Surpreendidos quando já estavam embarcando, foram presos. Conforme informa Antonio Borges Coelho, os Milão levavam consigo pertences de luxo,

338 ANTT, Inquisição de Lisboa, Caderno do Promotor 11, Livro 212, fol. 107v.

${ }^{339}$ Ibidem, fols. 107v-108.

${ }^{340}$ ANTT. Inquisição de Lisboa. Processo 17562.

${ }^{341}$ Idem.

${ }^{342}$ ANTT. Inquisição de Lisboa. Processo 3333.

343 ANTT. Inquisição de Lisboa. Processo Marco Antônio Nunes da Silva, O Brasil holandês nos cadernos do Promotor: Inquisição de Lisboa, século XVII. [Tese de Doutorado]. FFFLCH, USP, 2003. 
"como consta no rol dos objetos recenseados no ato da prisão, contavam-se, entre outras cousas, um cobertor de tafetá forrado de baeta, um travesseiro, duas almofadas, um cobertor de papa, um roupão de pérgula forrado de baeta verde, duas toalhas de águas ás mãos, um lençol, três panelas." Era morador em uma zona residencial muito prestigiosa, a Mouraria ${ }^{344}$. Também foram detidos Vicente Furtado (Álvaro Cousin), Antonio Mendes Cardoso, Manuel Sanches (secretário de Fernão Lopes de Milão), Gaspar Fernandes Penso e Fernão Rodrigues Penso. As pessoas armadas foram encarceradas na "Escola Gerais". Os membros da família Milão foram encarcerados na principal prisão da Inquisição em Lisboa.

Nos três anos que passaram no cárcere, os envolvidos na fuga frustrada acabaram confessando suas culpas de judaísmo, exceção feita ao patriarca da família, que foi relaxado na fé em 1609. Alguns dos acusados levados a tormento, como Gaspar Fernandes Penso, que perdeu um braço devido aos ferimentos sofridos na prisão e, assim mesmo, foi condenado às galés. ${ }^{345}$ Denunciaram-se uns aos outros, além de outros cristãos-novos, como consta dos processos inquisitoriais.

A leitura dos processos revela relações familiares, de amizade e econômicas, substanciais para a composição da rede de comércio dos Milão. Um dos melhores exemplos é o do tratante Vicente Furtado, ${ }^{346}$ primo de Álvaro Dinis, com ligações em Londres, presente na fuga e também foi preso.

"Disse que ele foi acompanhar Henrique Dias Milão para atender ao pedido de Fernando Lopes, filho de Henrique Dias. Fernando Lopes disse-lhe que seu pai devia muito dinheiro nos Contos do Reino e que ia para Flandres

\footnotetext{
${ }^{344}$ Antonio Borges Coelho. Política Dinheiro e Fé: op.cit. p. 107.

345 ANTT. Inquisição de Lisboa. Processo 17562.

${ }^{346}$ ANTT. Inquisição de Lisboa. Processo 3333.
} 
para casa de uma filha e que preso pelos familiares da Inquisição e pelo alcaide do mar de Belém, na enseada de Santa Catarina. Achando-o ali o prenderam, como a Vicente Furtado, Fernando Rodrigues, Gaspar Fernandes Penso e Manuel Sanches, criado de Henrique Dias Milão. Ele acompanhou Henrique Dias pelo motivo que já disse e os acompanhou de graça. Disse que o prenderam numa salva acompanhando Fernando Lopes Milão que Ihe pediu e ele era seu amigo. Pediu que o acompanhasse porque ia para Flandres por causa de uma dívida que devia nos Contos do Reino. Prenderam-no na enseada de Santa Catarina, indo na sita salva Fernando Rodrigues Penso, Gaspar Fernandes Penso, António Mendes e Manuel Sanches, criado de Henrique Dias Milão, pai do dito Fernando Lopes Milão. Jerónimo Freire, cristão-novo, mercador, caixeiro de Álvaro Dinis e é português, casado com uma mulher que está em Santarém, cristã-velha e não quis ir com ele, Rui Fernandes Cardoso, cristão-novo, mercador, português, natural desta cidade e quatro filhos de Rui Fernandes e de sua mulher portuguesa que lá vive com ele em Hamburgo, André Rodrigues, Fernão Rodrigues, João Gomes e outro de 12 anos que não sabe o nome, todos moradores em Hamburgo; Fernão Dias, cristão-novo, mercador, natural desta cidade e Diogo Carlos, irmão de Fernão Dias, ambos solteiros, moradores em Hamburgo e Duarte Palácios, solteiro, cristão-novo, filho de Manuel de Palácios que mataram nesta cidade através de uma estocada. Duarte de Palácios é seu primo e coirmão e que no dito tempo estava em Hamburgo, em casa de Álvaro Dinis e depois veio para Lisboa e embarcou para Cabo Verde, onde agora está. Em outubro passado foi nomeado vice-rei e foi para a Índia. Simão Barbosa, solteiro, 14 ou 15 anos, natural de perto de Vila do Conde que ia com ele e era seu criado e que agora 
está no Brasil na Baía de Todos-os-Santos, Francisco da Costa, cristão-novo, médico, irmão de Francisco da Costa e Manuel Fernandes, mercador, português, natural desta cidade, Gonçalo Cardoso, irmão de Rui Fernandes, Henrique Nunes, cristão-novo, confeiteiro, foi morador nesta cidade, casado com uma mulher que foi presa e que está lá com ele. Todos juntos na dita casa praticaram as coisas da lei de Moisés."

Todos foram condenados e penitenciados no auto de fé de maio de 1609 a penas diversas, enquanto Francisco Barbosa e Henrique Dias de Milão foram relaxados na fé.

Os Milão foram condenados a viver no bairro penitencial e não tinham permissão para deixá-lo. Apesar disso, em abril de 1610, Fernão Lopes Milão juntou-se a Bento Rodrigues, sua mulher Mor Rodrigues e a filha Violante Francesa; Pascoal Rodrigues e sua mulher Leonor Cardoso; Leonor Rodrigues, mulher de Francisco Sanches, com a enteada Ana Martins e a filha Isabel Dias e conseguiram se evadir de Portugal. A fuga considerada muito auspiciosa, de acordo com as declarações do alcaide Jorge da Costa aos inquisidores e Guiomar Gomes quando inquirida, declarou desconhecer seu paradeiro. ${ }^{347}$

Na sexta-feira depois do Entrudo de 1611, o alcaide das Escolas Gerais avisou que Guiomar Gomes e seus filhos, Gomes Rodrigues Milão, Ana de Milão, Isabel Henriques, Leonor Henriques; a sobrinha Beatriz Rodrigues e a sua "cabra" Vitória Dias, todos moradores à Mouraria tinham ido para Flandres, e deixaram tudo para trás.

Grande parte da família Milão reuniu-se em Hamburgo antes de 1615, juntando-se a Beatriz Henriques e Álvaro Dinis. Nesta cidade, estabeleceram-

${ }^{347}$ ANTT. Inquisição de Lisboa. Processo 3333. 
se Guiomar Gomes, a chinesa Vitória Dias; Henrique Rodrigues e sua mulher Leonor Henriques; Pêro de Palácios e a caçula dos Milão, Isabel Henriques, agora sua mulher; e Paulo de Milão. Gomes Rodrigues de Milão e Manuel Cardoso Milão ${ }^{348}$ fixaram-se em Amsterdã. Após a fuga das Escolas Gerais, Fernão Lopes Milão esteve em Amsterdã e, em 1612, desempenhava as suas atividades de mercador e parece ter adotado o nome de Daniel Abensur. Todos os irmãos homens voltaram ao trato.

\subsection{A rede de comércio dos Dias de Milão: de Goa ao}

\section{México}

O estabelecimento de judeus e cristãos novos em Amsterdã e Hamburgo se deu, grande parte das vezes, por membros das mesmas famílias ou por conhecidos, reforçando os laços comerciais e parentais entres diversos núcleos e a rede era mantida e reforçada pelo casamento endogâmico. A dependência entre eles se aprofundou para que pudessem trocar conhecimento e experiências e, assim, aumentar as chances de sucesso. ${ }^{349}$ Nesse novo momento, onde houve forte imigração para outros polos de atração para os cristãos-novos e judeus portugueses, especialmente Hamburgo, Rouen e Amsterdã e um pouco mais à frente, Londres.

A família de Guiomar era de mercadores e banqueiros com ação em diversos locais da Europa, na Ásia e na América. Seu tio materno Fernão Lopes era natural da Covilhã, tinha se estabelecido em Medina del Campo, na

348 ANTT. Inquisição de Lisboa. Processo 12493. Na comunidade sefardita de Amsterdã Gomes adotou o nome Daniel de Olanda, onde comerciava têxteis, diamantes e açúcar para Hamburgo, foi um dos fundadores da comunidade judaica de Londres. Cf. Studia Rosenthaliana, vol. VI, n ${ }^{\circ}$, Van Gorkun: University Library of Amsterdam, 1972, p. 120-121.

${ }^{349}$ Idem, p.108-110. 
Espanha, onde se realizavam feiras ligadas ao negócio da pimenta; Henrique Dias, mercador casado com Antónia Rodrigues, morador em Lisboa e que teve filhos já defuntos na Índia, Os seus filhos eram: Isabel Rodrigues já defunta e foi casada com António Mendes já defunto que tiveram duas filhas, Beatriz Mendes casada com Belchior de Barros, mercador e Filipa Rodrigues casada com Henrique da Guerra e que todos faleceram no Peru os quais têm filhos nesta cidade. ${ }^{350}$

As casas comerciais de destaque eram formadas por membros de uma mesma família, e normalmente irmãos se distribuíam pelas cidades mais importantes europeias. Já o pai, o líder, ficava assentado em Lisboa, se encarregava de enviar os filhos menores como caixeiros e correspondentes para as Índias, Goa ou Cochim e Pernambuco ou Bahia, os centros açucareiros do Brasil. No último quartel do século $\mathrm{XVI}$, e início do século $\mathrm{XVII}$, muitos chefes dessas casas mudaram-se para Antuérpia, Amsterdã e Europa do Norte. ${ }^{351}$ Daniel Swetschinski ${ }^{352}$ explicita a dinâmica desse tipo de casa comercial que recria em miniatura a composição e dinâmica das redes de comércio, envolvendo o Norte da Europa e Portugal.

O sustentáculo das casas comerciais era a família. Essa instituição que agregava vários núcleos unidos por vínculos de parentesco e laços sangue, que atuavam de forma conjunta seguindo uma estratégia definida por interesses comuns e compartilhada sob a direção de um chefe familiar.

Esse deslocamento estava muito ligado à expansão dos novos vetores do comércio europeu que seguiam nessa direção. As redes de comércio, no

\footnotetext{
${ }^{350}$ ANTT. Inquisição de Lisboa. Processo 6671.

${ }^{351}$ Florbela Veiga Frade. O Trato e a Família.op.cit. p.309- 317.

352 Daniel M. Swetschinski. Reluctant Cosmopolitans. The Portuguese Jews of Seventeenth Century in Amsterdam. Portland: Or: The Littman Library of Jewish Cilivization, 2000.
} 
entanto, se mantinham coesas e dinâmicas com a integração de elementos de outras casas comerciais como correspondentes ou pela associação entre grupos mercantis.

Em fins dos Quinhentos e início dos Seiscentos, os Ximenes, João Moreno, os Dias de Milão, os Fernandes Anjo, os d'Elvas, os d'Évora e Veiga são eram sobrenomes constantes na documentação relacionada ao comércio com o Brasil e com grande influência também no Oriente. Isso reflete a importância e a versatilidade desse grupo de mercadores na implantação da empresa colonial em suas frentes mais rentáveis. ${ }^{353}$

A rede dos Dias de Milão tinha sua "sede" em Lisboa, comandada pelo patriarca Henrique, com atuação transcontinental, no açúcar, em Pernambuco e Bahia, nos contratos da pimenta e especiarias do Oriente, no tráfico de escravos em Cabo Verde e Angola, o abastecimento da prata espanhola, no México, na reexportação do açúcar em Hamburgo e Londres, em Madri, no Porto, nos diamantes e pedras preciosas em Antuérpia, ou seja, as mercadorias tidas como "nobres" na época nos principais centros de comércio. Comerciantes de grosso trato eram ligados aos Ximenes de Aragão, parentes diretos de Guiomar Gomes, mulher de Henrique Dias de Milão, com os quais mantinham estritas relações econômicas, de amizade e laços familiares.

Henrique Dias de Milão teve como sócio no contrato das terças durante seis anos o cristão-novo Gabriel Ribeiro, morador em Lisboa. Gabriel Ribeiro, natural de Lagos, foi logo cedo residir em Lisboa de onde gerenciou seus negócios em várias frentes, tanto no comércio atlântico, quanto no oriental. Homem de imensa fortuna, manteve também outros contratos de extrema

${ }^{353}$ Leonor Freire Costa. O transporte no Atlântico e a Companhia Geral do Comércio do Comércio (1580-1663), op. cit, p.189. 
relevância: o dos dízimos do Estado do Brasil; uma parte do da Alfândega; de Ceuta e de Tanger; das ilhas e de Mazagão. ${ }^{354}$ Entre 1599 a 1605, o provimento das forças em Ceuta e Tanger corria através de Jorge Roiz da Costa e as rendas dos Açores pertenciam ao contratador Gabriel Ribeiro por $40.000 \$ 000$ ao ano; ${ }^{355}$ as da Madeira, de 1602 a 1608, foram cedidas a Francisco Roiz Vitória, ao preço de $21.400 \$ 000$ por ano; as de Barlavento a Simão Roiz Mantua, de 1602 a $1606 .{ }^{356}$ Na Colônia, o arrendamento das dízimas era o contrato mais importante, e, portanto, o mais cobiçado pelos grandes comerciantes lusos. Quem primeiro o deteve foi o cristão-novo Bento Dias de Santiago, um dos primeiros senhores de engenho em Pernambuco, homem de grandes capitais, que foi sucedido por Gabriel Ribeiro. ${ }^{357}$ E assim, durante todo o século XVII, correu quase sempre pelas mãos de indivíduos da estirpe hebreia. Gabriel Ribeiro associava-se também a Gaspar Ximenes, dos ramos dos Ximenes de Aragão de Antuérpia. Seu irmão Francisco Ribeiro, em 1604, foi contratador dos dízimos da Bahia e procurador do irmão em $1608 .{ }^{358}$

As somas que envolviam os contratos eram vultosas, chegando a 500 mil cruzados. ${ }^{359}$ Os negócios de Gabriel Ribeiro não se restringiam aos contratos, sendo seus interesses muito mais amplos, visto ter se deslocado diversas vezes para Madri e Valladolid, em virtude de seus interesses comerciais inclusive com Fernão Lopes de Milão. Este relatou ao Santo Ofício

\footnotetext{
${ }^{354}$ Antonio Borges Coelho. Política e Fé. Cadernos de Estudos Sefarditas, op.cit.. p.112.

${ }^{355}$ José Antonio Gonçalves. Magnatas do Tráfico Negreiro...op.cit.p. 34

${ }^{356}$ Idem, p. 57,83.

${ }^{357}$ Ibidem, 55.

${ }^{358}$ Daniel Strum. The Portuguese Jews and New Christians in the Sugar Trade, op.cit. p. 255; 298.

359 Apenas como meio de comparação, Dom Sebastião em 1577, preparando-se para sua empreitada militar no norte da África, que resultou na batalha de Alcácer-Quibir onde perdeu a vida, concedeu a isenção dos confiscos de bens aos cristãos novos por mais dez anos e anulou a proibição de que eles deixassem Portugal em troca da doação de 250 mil cruzados. Estima-se que os custos da invasão do Norte da África pelo rei português tenham ficado por volta de 600 mil cruzados. Antonio José Saraiva. Inquisição e cristãos-novos. Lisboa: Estampa, 1994, p. 182
} 
ter ido muitas a Madri, a Valladolid e a Sevilha e tinha partes nos negócios, e tinha feito muito bom dinheiro. ${ }^{360}$ Como o global player citado Cátia Antunes, ${ }^{361}$ Gabriel Ribeiro ainda tinha interesses comerciais no Peru, Brasil e llha Margarita, representado por seus parentes diretos (tios, primos e irmão). Seu filho, Garcia Ribeiro (que embora se dissesse fosse um verdadeiro católico, veio a assumir a liderança dos judeus em Veneza) vivia em Florença e mantinha contato com os judeus das cidades italianas e do Império Otomano. ${ }^{362} \mathrm{O}$ poderoso contratador e mercador foi preso pela Inquisição em abril de 1609, acusado de judaizante, tendo ficado por dois anos nos cárceres das Escolas Gerais. ${ }^{363}$

Por volta de 1591 esteve na capitania de Pernambuco o mercador Francisco Lopes Homem, regressando depois ao reino, onde deixou seu sobrinho, Manuel Lopes Homem, cuidando de seus negócios. Manuel estava em Angola durante a Visitação e logo regressou a Pernambuco, provavelmente com escravos africanos. ${ }^{364}$ Manuel vivia nos Açores, estivera em Amsterdã e em Hamburgo, e estava ligado ao tráfico negreiro nos Açores. Por volta de 1582 e 1584, morou em Pernambuco um Manoel Rodrigues Villareal, cristãonovo que veio ao Brasil com escravos de Angola. Estava com ele seu irmão mais velho de nome Francisco Rodrigues Villareal. ${ }^{365}$ Bastião Pereira também chegou a Pernambuco vindo de Angola com peças de Leonardo Frois, mercador de Lisboa, do qual era feitor. ${ }^{366}$

\footnotetext{
${ }^{360}$ ANTT, Inquisição de Lisboa, processo, 2523.

${ }^{361}$ Cátia Antunes. Globalization in the Early Modern Period, op.cit. p 35.

${ }^{362}$ Antonio Borges Coelho. Política e Fé. op.cit. p. 111-112.

${ }^{363}$ ANTT, Inquisição de Lisboa, processo, 8056.

${ }^{364}$ Livro das Denunciações de Pernambuco. p. 113;115.

${ }^{365}$ Livro das Denunciações de Pernambuco. p. 353, 470.

${ }^{366}$ Livro das Denunciações de Pernambuco. p. 420.
} 
As primeiras notícias que temos dos Milão colocam Henrique, seus irmãos, cunhados e sogro no Oriente, onde ele diz ter vivido por muitos anos. $^{367}$ Henrique De Milão estava diretamente ligado aos negócios da pimenta, bem como seu cunhado, Rodrigo de Andrade, casado com sua irmã, Ana de Milão, estabelecido em Lisboa, com deslocamentos frequentes a Madri e a Sevilha, que mantinha intensos negócios com seus primos Tomás e Fernão Ximenes e os Rodrigues d'Evora em Antuérpia, em 1577-1578. ${ }^{368}$

Os Dias de Milão participaram da exploração da prata por meio de Antonio Dias de Cáceres, irmão de Henrique Dias de Milão, que explorava as minas de Tampico e do tráfico de escravos. ${ }^{369}$

Henrique Dias de Milão teve como sócio no contrato das terças durante seis anos, o cristão-novo Gabriel Ribeiro, morador em Lisboa. Gabriel Ribeiro, natural de Lagos, foi logo cedo residir em Lisboa de onde gerenciou seus negócios em várias frentes, tanto no comércio atlântico, quanto no oriental. Homem de imensa fortuna manteve também outros contratos de extrema relevância: o dos dízimos do Estado do Brasil; uma parte do da Alfândega; de Ceuta e de Tanger; das ilhas e de Mazagão. ${ }^{370}$ Entre 1599 a 1605, o provimento das forças em Ceuta e Tanger corria através de Jorge Roiz da Costa e as rendas dos Açores pertenciam ao contratador Gabriel Ribeiro por $40.000 \$ 000$ ao ano; $;^{371}$ as da Madeira, de 1602 a 1608, foram cedidas a

\footnotetext{
${ }^{367}$ ANTT. Inquisição de Lisboa. Processo 6677.

368 José Gentil da Silva. Merchandises e Finances -Letrres de Lisbonnes.T.III. Paris: SEVPEN., 1961, p.194; 197; 201.

${ }^{369}$ James C. Boyajian. Portuguese Trade in Asia under the Habsburgs 1580-1640, op.cit. p. $142-143$

${ }^{370}$ Antonio Borges Coelho. Política e Fé. Cadernos de Estudos Sefarditas. op.cit. p.112

${ }^{371}$ José Antonio Gonçalves. Magnatas do Tráfico Negreiro...op.cit.p. 34
} 
Francisco Roiz Vitória, ao preço de $21.400 \$ 000$ por ano; as de Barlavento a Simão Roiz Mantua, de 1602 a $1606 .{ }^{372}$

Álvaro Dinis, que era genro de Henrique Dias de Milão, morava em Hamburgo e mudou-se para Altona, próximo a Hamburgo, a convite do rei Christian IV, então território dinamarquês. Em 1616, numa tentativa de acabar com o comércio de Hamburgo, o rei da Dinamarca, Christian IV, fundou, às margens do rio Elba, a cidade de Glückstadt. Convidou Álvaro Dinis, abastado judeu sefardita de Hamburgo, para administrar a Casa da Moeda em Glückstadt, responsável por cunhar as moedas reais. Três anos depois, visando estimular a economia da cidade, Christian IV estendeu o convite a outras trinta famílias sefarditas. Em 1628, os judeus da cidade conseguiram autorização para ter um cemitério e se reunir em residências para os serviços religiosos.

Do clã de Henrique Dias de Milão, que teve nove filhos: dos seus cinco filhos homens, quatro viveram ao Brasil e eram comerciantes em Pernambuco, onde se situava o núcleo dos negócios da família na exportação do açúcar e no contrato do pau-brasil. O primogênito, Manuel Cardoso de Milão, era contratador do pau-brasil e o líder dos negócios, morava em Pernambuco com o irmão Antonio Dias e por algum tempo com Gomes Rodrigues de Milão ${ }^{373}$, que era seu caixeiro. ${ }^{374}$ Manuel Cardoso de Milão vivia em Olinda, na rua da Serralheria, e muitos cristãos-novos visitavam diariamente a sua casa, como Tomás Fernandes, Manuel Carvalho, Duarte e Antonio Saraiva Coronel

\footnotetext{
${ }^{372}$ Idem, p. 57, 83.

${ }^{373}$ ANTT. Inquisição de Lisboa, processo 2523.

${ }^{374}$ Em 1612, em Amsterdã, Gomes Rodrigues de Milão declarou ter sido caixeiro de Manuel
} Cardoso de Milão perante o tabelião Mostart, e que este fato foi confirmado por Thomas Fernandes, Manuel Carvalho, Duarte Saraiva e Antonio Senior Coronel. Egon e Frieda Wolff. Judeus em Amsterdã. p. 80 . 
(riquíssimo mercador, um dos primeiros que se fixou em Amsterdã, com o nome de David Senior Coronel). ${ }^{375}$ Apareceu mais tarde em Hamburgo como Manuel Teixeira, grande comerciante, ligado a Álvaro Dinis (Samuel Jachia Eanes), Paulo Milão (Paul Diederisen). ${ }^{376}$

Em 1593, Gomes Rodrigues Milão declarou à Visitação do Santo Ofício em Pernambuco ter 20 anos e residir na casa do irmão, Manuel Cardoso Milão, que era negociante do açúcar. ${ }^{377}$ Foi preso com o pai e o irmão Paulo, e este declarou ao Santo Ofício ter estado também no Brasil e retornado antes de $1605,{ }^{378}$ tendo estado no Brasil por 14 anos e retornado ao Reino em janeiro desse mesmo ano, portanto, tendo chegado ao Brasil por volta de $1591 .^{379} \mathrm{Na}$ época do encarceramento, estavam em Pernambuco outros dois filhos de Henrique, Manuel Cardoso, 36 anos, e Antônio Dias, 25 anos, ambos solteiros e tratantes, que trabalhavam com açúcar. ${ }^{380}$ Disse que com seu irmão Manuel Cardoso, solteiro, mais velho e ambos negociavam fazenda de seu pai e de outras pessoas. Que ele nunca teve nem mandou a este reino e a seu pai alguma coisa, nem trouxe consigo, mas o que negociou era de seu pai. ${ }^{381} \mathrm{Em}$ Pernambuco desempenhava as funções de tesoureiro e feitor, além de fazer o despacho das mercadorias da alfândega. ${ }^{382}$ Depois da morte do progenitor e seu julgamento, fugiu e transferiu-se para Amsterdã, onde adotou o nome de Daniel de Olanda.

\footnotetext{
375 José Antonio Gonçalves de Mello. Gente da Nação: Cristãos-Novos e Judeus em Pernambuco, p. 16.

${ }^{376}$ Joseph Ben Brith. Die Odysse Henrique-Familie, op.cit, p. 62.

377 José Antonio Gonçalves de Mello. Gente da Nação: Cristãos-Novos e Judeus em Pernambuco 1542-1654. Op.cit. pp. 16-17.

${ }^{378}$ Antonio Borges Coelho. Política e Fé, op. cit. p. 107-108.

${ }^{379}$ ANTT. Inquisição de Lisboa. Processo 2499.

${ }^{380}$ ANTT. Inquisição de Lisboa. Processo 6677.

${ }^{381}$ ANTT. Inquisição de Lisboa. Processo 6677

382 José Antonio Gonçalves de Mello. Gente da Nação: Cristãos-Novos e Judeus em Pernambuco 1542-1654, op.cit, p. 17.
} 
Manoel Nunes de Matos era casado com Ana de Milão, contratador na cidade de Lisboa, mercador e senhor de engenho em Pernambuco. ${ }^{383}$ Voltou a Lisboa após saber da prisão da mulher e do sogro. Em 1608 estabeleceu-se em Amsterdã, ${ }^{384}$ onde mantinha intenso contato com o convertido na fé hebreia James Lopes da Costa $^{385}$ e se deslocava para Hamburgo a negócios. Em 1609, seu irmão, João Nunes de Matos, era senhor de engenho ${ }^{386}$, quando ele já se encontrava estabelecido em Hamburgo. Morreu judeu em Amsterdã, em 1621, embora tenha sido processado pela Inquisição de Lisboa já mesmo defunto. ${ }^{387}$ Era um dos mais expressivos mercadores do Atlântico de açúcar e de escravos e associado dos Tinocos, Pero de Galegos e Antonio Mendes Lamego (este, contratador de escravos em 1587) ${ }^{388}$ além de contratador dos dízimos da capitania no ano de 1601, por 7.000 cruzados. $^{389}$ Manoel Nunes de Matos era cunhado de Pero de Galegos, que era casado com sua irmã Apolônia Ximenes. ${ }^{390}$ 2008, p. 294

${ }^{383}$ ANTT. Inquisição de Lisboa. Processo 10600.

${ }^{384}$ Idem

385 Studia Rosenthaliana 1271; ANTT. Inquisição de Lisboa. Processo 10600.

${ }^{386}$ Rodrigo Ricupero. A formação da elite colonial. Brasil 1530 - 1630. São Paulo: Alameda,

${ }^{387}$ Morreu em 1621. Auto-de-fé de 14 de março de 1627 e celebrado no Ribeira na cidade de Lisboa. Crime de heresia e apostasia, seus ossos entregues à justiça secular e queimados, bens confiscados, excomunhão maior . ANTT. Inquisição de Lisboa. Processo 10600.

${ }^{388}$ Pedro de Sevilha e Antonio Mendes Lamego obtiveram o asiento de Angola entre 1587 e 1592. Com uma soma fixa de 11 mil réis. Frederic Mauro. Portugal, o Brasil e o Atlântico 1570-1671. v I Lisboa: Editorial. Estampa. p. 215. 'George Scell explica que se tratava de titulares do asiento só será recebido dos particulares no regresso, depois do escoamento de todas as cargas. Trata-se de uma verdadeira forma de crédito. Da mesma forma, as rendas e outros encargos atuais: os titulares do asiento comprometem-se, para além do preço combinado, a dar dois negros de que S. M. fará presente a quem lhe aprouver - têm que pagar todos os anos $10 \%$ de obras pias para o Tesouro Real, e por uma só vez, 200 000 mil réis às irmãs de Nossa Senhora da Esperança. Da mesma a forma que o rendeiro deve hoje deixar a sua terra em bom estado ao seu sucessor, o titular do asiento não deve, no fim do contrato, conceder mais licenças do que cada um dos primeiros anos. Apud: Frederic Mauro. Portugal, o Brasil e o Atlântico 1570-1671 v I. op.cit. p. 214.

${ }^{389}$ Lista de receitas e despesas de Ambrósio Siqueira como. Relação de Ambrosio de Siqueira (1605) da Receita e despesas do Estado do Brasil. In: Revista do Instituto Arqueológico, Histórico e Geográfico Pernambucano, Recife, N.49. p. 125-234; p. 152.

${ }^{390}$ ANTT. Inquisição de Lisboa. Processo Manoel Nunes de Matos, nº 10600. 
Fernão Lopes Milão foi preso junto com a família e declarou aos inquisidores ser mercador, solteiro e ter 31 anos tendo-se deslocado principalmente a Castela, frequentando os centros econômicos e financeiros do período Valladolid, Medina del Campo e Madrid. ${ }^{391}$ Fernão Lopes Milão emprestou muito dinheiro a fidalgos que nunca pagaram, emprestou 100.000 reis a Luís Mendes de Vasconcelos, 60.000 reis a D. Maria de Menezes, mulher do conde de Calheta, 50.000 reis a Aleixo de Leão, almoxarife dos mantimentos, 60.000 reis a Matias Correia que tem um ofício na capela, 100 reis a Gil Eanes da Silveira, outra quantidade a um filho do escrivão do paço da Madeira e outras muitas pessoas além do dinheiro que gastou, despendeu muitas mercadorias ricas: uma alcatifa que comprou a Gaspar Ximenes por 140.000 reis, muitos panos ricos, uma mula muito fermosa. ${ }^{392}$ Mercador atuante mantinha intenso trato com Pernambuco e Bahia ${ }^{393}$. Henrique Dias de Milão queixava-se que gastara muito em Castela, emprestando dinheiro a fidalgos que mal Ihe pagavam. O trato era muito mais rentável. ${ }^{394}$

Em Hamburgo, o correspondente dos Milão era Álvaro Dinis. Os Palácios, primos dos Dinis, também aparecem na documentação como mercadores de grosso trato ligados às principais casas comerciais da segunda metade do século XVI e primeiras décadas do XVII. Vicente Furtado, também primo de Dinis, fazia negócios com Veneza, Antuérpia, Salônica e tinha como

\footnotetext{
${ }^{391}$ ANTT. Inquisição de Lisboa. Processo 2523.

${ }^{392}$ ANTT. Inquisição de Lisboa. Processo 6677.

393 José Antonio Gonsalves de Mello. Gente da Nação. Cristãos-novos e judeus em Pernambuco, op.cit. p. 11

${ }^{394}$ Antonio Borges Coelho. Política e fé. op. cit. p. 111.
} 
seu correspondente em Londres, Gabriel Fernandes, ${ }^{395}$ de quem comprava tecidos e lã e vendia madeira do Brasil. ${ }^{396}$

Filipe Dinis teria sido um dos primeiros cristãos-novos a ser proprietário de engenho em Pernambuco, nos primeiros anos da segunda metade do século XVI. ${ }^{397}$ Nos anos 1590, estavam ligados também aos irmãos Dias de Milão, em Pernambuco. Álvaro Dinis talvez tenha vindo ao Brasil com o nome hebraico de Samao ou Semuel Hiae, como forma de não se identificar e fazer transações ilegais. ${ }^{398}$ Boyajian o aponta como um dos grandes investidores na Rota do Cabo nas décadas de 1580 e $1590 .^{399}$

A influência, o poderio econômico e o prestígio social de Rodrigo Andrade e Henrique Dias de Milão podem ser medidos no episódio no qual estiveram envolvidos na assinatura da fiança que aconteceu na casa de Rodrigo de Andrade para a soltura de João Nunes Correa, que foi preso em 1591 no Brasil, conforme mencionado no capítulo 1.

O cristão-novo João Nunes Correia - um dos maiores mercadores da época, contratador de escravos e de pau-brasil, senhor de engenho, onzeneiro (agiota) dono de uma fortuna imensa, avaliada em 200 mil cruzados - foi preso pela Inquisição em 1592 foi levado a Lisboa onde seria julgado.

Ao chegar a Lisboa, em janeiro de 1593, mesmo preso e devendo ser entregue às autoridades eclesiásticas, conseguiu deixar o navio, ficando três dias livre, quando tratou de negócios de seu interesse. ${ }^{400}$ Menos de dois meses de ter chegado ao Reino, a sua influência e poder na sociedade lisboeta e sua

\footnotetext{
395 ANTT. Inquisição de Lisboa 6783

${ }^{396}$ ANTT. Inquisição de Lisboa 3333.

${ }^{397}$ José Antonio Gonsalves de Mello. Gente da Nação, op.cit, p. 8.

${ }^{398}$ Joseph Ben Brith. Dye Odissee der Henrique Familie, op.cit, p. 25-26.

399 James C. Boyajian. Portuguese Trade in Asia under the Habsburgs 1580-1640, op.cit.

${ }^{400}$ Silvia C. Ricardo. As Redes de Comércio, op.cit., 133;135.
} p.197. 
extensa rede de negócios devem ter pesado para a sua absolvição por falta de provas. Esse fato chama a atenção, visto que muito raramente o acusado saía livre do cárcere sem qualquer condenação dada pelo Santo Ofício. Para tal, sua fiança foi estipulada no valor de quatro mil cruzados, que foi prontamente paga por expoentes mercadores do trato luso.

Reunidos na casa de Rodrigo Andrade para assinar a escritura de soltura, seus fiéis carcereiros e fiadores foram o próprio Rodrigo ${ }^{401}$ e Jerônimo Henriques, senhor de engenho em Pernambuco, que emigrou para Amsterdã em 1609, continuando a ter grande projeção no trato internacional. ${ }^{402}$ Os abonadores foram Vasco Martins da Veiga, Henrique Dias de Milão e Manuel Fernandes Anjo. O primeiro deles, Vasco Martins da Veiga, era mercador e aparece ligado ao negócio da pimenta em 1595, conforme carta assinada por Rodrigues Lopes de Évora. ${ }^{403}$ Seu filho, Pedro da Veiga, casado antes de 1599, com uma filha de Simão da Veiga, trabalhava em Madrid com seu sogro, e retornou a Lisboa em 1610. Os negócios dos Veiga, no qual Pedro trabalhava, diziam respeito à expedição de açúcar e outras mercadorias de Sevilha através de Calais, Hamburgo e outras praças do norte da Europa ${ }^{404}$. 0 segundo abonador foi Henrique Dias de Milão. O terceiro, Manuel Fernandes Anjo, era mercador da família de Gaspar Fernandes Anjo, senhor de dois engenhos em Pernambuco e ligado à reexportação de açúcar para Antuérpia e Amsterdã. ${ }^{405}$ João Nunes continuou na mercancia, obtendo autorização do

\footnotetext{
${ }^{401}$ ANTT. Inquisição de Lisboa. Proc. 12464. na Itália.

${ }^{402}$ Jerônimo Henriques, pertencente a uma família de grande fortuna ligada a judeus de Ferrara

${ }^{403}$ J. Gentil da Silva. Strategie des Affaires a Lisbonne entre 1595-1607, op.cit, p.134.

${ }^{404}$ Idem. p. 5

405 Irmão de Gaspar Fernandes Anjo, senhor de dois engenhos em Pernambuco, grande exportador de açúcar, família de grande projeção comercial.
} 
Santo Ofício para deixar o Reino. Mudou-se para a Espanha, onde continuou fazendo negócios junto com seu sobrinho João Nunes Saraiva. ${ }^{406}$

\subsection{A rede de comércio dos Milão no açúcar brasileiro}

Leonor Freire Costa nos diz que os mais poderosos mercadores lusos cristãos-novos, como os Ximenes e seu parente João Moreno, os Dias de Milão, os Elvas e Veigas eram muito atuantes no tráfego marítimo com o Brasil e o Oriente, nos primeiros anos do XVII. Esses grupos estiveram presentes desde os primórdios da expansão açucareira na Colônia, além terem investido seus cabedais em muitas das frentes do trato colonial. ${ }^{407}$

Senhores de engenho e mercadores deslocavam-se com frequência do Brasil para Portugal, mas sempre deixando aqui representantes seus. Entre os muitos exemplos estão os primos Miguel Dias Santiago e Duarte Dias Henrique que eram senhores de engenho na década de 1590. Voltaram ao Reino e lá se estabeleceram, tornando-se ativos importadores de açúcar do Brasil. Essa premissa é reforçada por Leonor Freire Costa, ao dizer que "homens que residiam em certas localidades brasileiras, expedindo mercadorias por ordem de outrem, encontram-se pouco mais tarde no reino e a executar tarefas semelhantes às que anteriormente eram desempenhadas pelos seus correspondentes." ${ }^{408}$

Ao analisarmos os maiores exportadores de açúcar entre 1596 e 1605, apontados por Gonsalves de Mello, baseando-se no livro de Entrada e saída dos navios e urcas do Porto de Pernambuco (manuscrito) que lista os

\footnotetext{
${ }^{406}$ Silvia C. Ricardo. As Redes de Comércio, op.cit, p. 152 -160

${ }^{407}$ Leonor Freire Costa. O transporte no Atlântico... op. cit., p 189.

${ }^{408}$ Idem. p. 292.
} 
carregadores em Pernambuco e consignatários em Lisboa entre os anos de 1596 a 1605, constatamos que os dois maiores eram ${ }^{409}$ :

- Duarte Ximenes: 5.375 arrobas ou 80.625 quilos, sendo a maior parte consignada em Lisboa a Guilherme Duarte, provavelmente o mercador flamengo Guilerme Lenaerts; outra parte era consignada a diversos Ximenes residentes em Lisboa: André, Gonçalo, Fernão e Manuel. Senhor de engenho em Goiana, Capitania de Itamaracá, tornou-se rendeiro dos contratos dos dízimos de açúcar entre 1627-1621. Era irmão de Gaspar Ximenes e primo de Antonio Nunes Ximenes, ambos senhores de engenho, este último filho de Rui Nunes Ximenes, um dos mais proeminentes mercadores lusos. Seus irmãos Duarte e Fernão Ximenes de Aragão estabeleceram um "império comercial mundial, com sede em Antuérpia." $\$ 10$

- Manuel Nunes de Matos (cristão-novo e senhor de engenho): 4.662 arrobas ou 69.930 quilos. Irmão de Simão Nunes de Mattos, também senhor de engenho, o último dono do engenho da Maré, em Salvador. Mantinha estreitas ligações com André e Fernão Ximenes e era sócio de João Moreno, mercador e senhor de engenho. Segundo Leonor Freire Costa, João Moreno liderava um dos sete principais grupos de comerciantes em Portugal. ${ }^{411}$ Além disso, era genro de Henrique Dias de

${ }^{409}$ Biblioteca Nacional de Lisboa. Reservados, Coleção Pombalina, códice 642, fls. 204-235 e cópia na Biblioteca Nacional do Rio de Janeiro. Manuscrito, códice II - 33, 6, 30. Apud. Ibidem, p. 1011.

\footnotetext{
${ }^{410}$ Ibidem, p. 11.

411 Leonor Freire Costa. O transporte no Atlântico... op. cit., p 201.
} 
Milão. Manuel Cardoso de Milão e Manuel Nunes de Matos produziam e exportavam o açúcar que era distribuído para a Europa ${ }^{412}$.

Henrique, Pero de Galegos e João Moerno, na capital do reino, com o sobrinho Francisco de Cáceres, na cidade do Porto, e com os Ximenes, em Antuérpia, certamente eram fundamentais para os interesses de Henrique nesta atividade. O açúcar era a principal atividade da rede dos Milão, embora, como vimos, tivessem interesses em maior ou menor grau nos negócios mais rentávies do período. O envolvimento do clã Ihes dava posição privilegiada nesse negócio, visto que controlavam desde a produção até a distribuição. Uma intricada rede familiar estava ligada ao açúcar, no qual se destacam consignatários, caixeiros e correspondentes. A documentação levantada indica que esses mercadores e agentes eram cristãos-novos, aparentados e pertencentes à elite mercantil lusitana.

Em 1592, o primogênito de Henrique, Manuel Cardoso de Milão, já estava instalado no Brasil, ligado ao açúcar, sendo seguido pelos irmãos Antonio Dias e Gomes de Milão. O genro Manuel Nunes de Matos era senhor de engenho em Pernambuco e o irmão de Simão Nunes de Matos, o último dono do engenho da Maré, em Salvador, João.

A importância dos Milão no negócio do açúcar era de tal de ordem que Gonsalves de Mello aponta Manoel Nunes de Matos como o segundo maior exportador de açúcar desse período, perfazendo 4.662 arrobas ou 69.930 quilos, atrás apenas de Duarte Ximenes. O mesmo documento traz o registro

${ }^{412}$ Lista de receitas e despesas de Ambrósio Siqueira como. Relação de Ambrosio de Siqueira (1605) da Receita e despesas do Estado do Brasil. In: Revista do Instituto Arqueológico, Histórico e Geográfico Pernambucano, Recife, N.49. p.125-234; 182. 
de embarques para exportação de Manuel Cardoso de Milão ou Gomes Rodrigues de Milão ${ }^{413}$ de 28 caixas de açúcar, sendo seu consignatário em Lisboa, o primo Pero de Galegos, e outra remessa de 24 caixas do mesmo produto, sendo consignatário em Lisboa, o pai, Henrique Dias de Milão. Segundo Gonsalves de Mello, um carregamento de três navios que deixaram Recife em 1602 e que aportaram em Hamburgo, na relação de carregadores constava: ${ }^{414}$

\section{Carregadores}

Manuel Cardoso Milão ou

Gomes Rodrigues Milão

Manuel Nunes de Matos

Duarte Ximenes

Manuel Cardoso Milão ou

Gomes Rodrigues Milão

\section{Consignatários em Lisboa}

\author{
Pero de Galegos \\ João Moreno \\ João Moreno \\ Henrique Dias Milão
}

No Porto, os Milão tinham como representante Francisco de Cáceres, e em Lisboa, Pero de Galegos, ambos sobrinhos de Henrique Dias de Milão. O sobrinho João Moreno tinha morado no Brasil, sendo senhor de engenho, era mercador e correspondente dos Ximenes por volta de $1590 .^{415}$ Voltou a Lisboa

${ }^{413}$ Em 1612, em Amsterdã, Gomes Rodrigues de Milão declarou ter sido caixeiro de Manuel Cardoso de Milão perante o tabelião Mostart, e que este fato foi confirmado por Thomas Fernandes, Manuel Carvalho, Duarte Saraiva e Antonio Senior Coronel. Egon e Frieda Wolff. Judeus em Amsterdã. p. 80.

${ }^{414}$ Idem. P. 15-16.

${ }^{415}$ Procuração passada por João Álvares da Costa [1590], morador em Vila do Conde, a Gaspar Carneiro, morador em Vila do Conde, estante na cidade de Lisboa, para que possa receber de Tomás Ximenes, mercador e morador na cidade de Lisboa, cerca de 24000 reais referentes a uma letra passada na vila de Olinda, capitania de Pernambuco sobre o dito Tomás Ximenes, por João Moreno.

PT/ADPRT/NOT/CNVCD14/001/0019/00004 I/36/4 - 4.1017, fl 90-91. 
onde mantinha intenso trato com Pernambuco e Bahia, ${ }^{416}$ e segundo Leonor Freire Costa, liderava um dos sete principais grupos de comerciantes em Portugal. $^{417}$

Nessa complexa relação mercantil, encontramos o mesmo João Moreno como um dos seus consignatários em Lisboa, carregador de vinho, açúcar, escravos, cargas de armação em 1596, 1600 e 1604, ${ }^{418}$ além de estar ligado ao negócio da pimenta como correspondente dos Ximenes de Antuérpia, e ser reconhecido "como um homem rico (com uma fortuna de mais de 50 mil ducados), leal e ativo". ${ }^{419}$ Em diversas correspondências de Manuel Veiga ${ }^{420}$ ele aparece como homem rico e comerciante de grandes feitos. Seu relacionamento com os grandes grupos mercantis, Rodrigues d'Elvas e os Ximenes, no negócio da pimenta fica patente pela procuração passada em $1590,{ }^{421}$ referente a uma letra de câmbio num montante total de 800.000 reais, valor de grande monta, o que reassegura o vulto econômico dos mercadores envolvidos na transação.

Leonor Freire Costa nos informa que as cargas que circulavam no Atlântico eram embarcadas pelos agentes dos fretadores dos navios, fossem

416 José Antonio Gonsalves de Mello. Gente da Nação. Cristãos-novos e judeus em Pernambuco 1542-1654, op.cit. p. 11.

${ }^{417}$ Leonor Freire Costa $O$ transporte no Atlântico e a Companhia Geral do Comércio do Brasil (1580-1663). op.cit. p.201

${ }^{418}$ Idem, p. 86.

${ }^{419}$ Carta de 18 de maio de 1602 de Manuel da Veiga aponta João Moreno e diz ser os Ximenes de Aragão, a elite do mundo dos negócios.J. Gentil da Silva. Strategie des Affaires a Lisbonne entre 1595-1607, op.cit., p. 233.

${ }^{420}$ Idem.

421 "Procuração passada por Ana Antónia, mulher de Pedro Francisco, piloto, ausente, a João Ribeiro, piloto da Carreira da Índia, morador em Lisboa, e a João Rodrigues, tanoeiro, morador em Vila do Conde, para poderem receber cerca de 800000 reais que João Moreno passara por letra a seu marido, Pedro Francisco, para lhos haver de pagar João Ximenes; 123200 reais por uma letra que António Cavalcante passou a seu marido para que lhos pagasse Rafael Fantona; 20000 reais do dito Rafael Fantona por outra letra do dito António Cavalcante; 46000 reais por letra passada por Manuel Dias, a pagar por João Duarte; 20000 reais por letra passada por João Gomes a pagar por Manuel Rodrigues de Elvas."

PT/ADPRT/NOT/CNVCD14/001/0017/00014 I/36/4 - 4.1017, fl 28v-30v(?) 
eles seus correspondentes ou procuradores. Assim, as remessas de açúcar para a metrópole e o envio de vinhos e objetos de luxo se davam por intermédio de uma teia de relações entre os elementos estabelecidos nos trajetos entres os portos, apesar da itinerância que marcava a atuação dessas redes.

O deslocamento dos agentes maiores, como avalia Strum, ${ }^{422}$ era frequente e encontramos na documentação mercadores do vulto de João Moreno, Pero de Galegos, Simão Nunes de Matos ora no Brasil, ora em Lisboa, ora em Amsterdã, invertendo suas posições como correspondentes e consignatários.

Dessa forma, ficamos sabendo Henrique Dias de Milão tinha como seus correspondentes em Pernambuco, entre 1580 e 1601, Manuel Cardoso de Milão, Gomes Rodrigues Milão e Manuel Rodrigues Cartagena, este último mercador cristão-novo ${ }^{423}$ e correspondente de outro destacado comerciante lisboeta, Gaspar Fernandes Anjo. ${ }^{424}$ Os dois outros correspondentes eram seus filhos. O fato de ter três correspondentes demonstra sua posição de destaque no trato açucareiro, como outros de seus pares. Essa mesma documentação nos mostra que Manuel Cardoso de Milão também era correspondente do mercador cristão-novo Diogo Francês ${ }^{425}$ nesse mesmo período e de Pero de 32.

${ }^{422}$ Daniel Strum. The Portuguese Jews and New Christians in the Sugar Trade, op.cit. p. 26-

${ }^{423}$ Era parente dos Rodigues d'Evora e Fernandes d'Elvas. ANTT, Inquisição de Lisboa, proc. 8474. Assumiu em Amsterdã sua identidade judaica. José Antonio Gonsalves de Mello. Gente da Nação, op.cit.p. 189.

${ }^{424}$ Leonor Freire Costa. O transporte no Atlântico e a Companhia Geral do Comércio do Comércio (1580-1663). op.cit. p. 303.

${ }^{425}$ Diogo Francês foi proprietário em Antuérpia de um imóvel na rua Meir, onde outros comerciantes da Nação Portuguesa também tinham propriedades. Seu filho Manuel Francês foi tesoureiro de Antuérpia em 1606 e Cônsul em 1615. Estava ligado ao comércio do Oriente, África e Brasil. Florbela Veiga Frade. As Relações Econômicas e Sociais das Comunidades Sefarditas Portuguesas. O Trato e da Família 1532-1632. op.cit. p.237. 
Galegos, seu primo, estes estabelecidos em Lisboa. ${ }^{426}$ Pero de Galegos confirma a atuação da rede também nas ilhas com os irmãos cristãos-novos Vitória de quem era correspondente em Lisboa. ${ }^{427}$ João Moreno, por sua vez, era correspondente em Lisboa dos Frias de Salazar, que viviam nas Canárias, juntamente com Manuel Fernandes Anjo, Gaspar Fernandes Penso, ${ }^{428}$ Paulo de Pina, Fernão Ximenes, entre outros.

Além disso, Manoel mantinha estreitas ligações com André e Fernão Ximenes e era sócio de João Moreno. Procurações lavradas no Arquivo Distrital do porto: "Procuração passada por Maria Carneira, mulher de Manuel da Fonseca, morador em Vila do Conde, ora estante e residente na vila de Olinda, a Baltasar Afonso Carneiro, pai dela, para cobrar, na cidade de Lisboa, a Pero de Galego [1604], mercador, o procedido da venda de 400 arrobas de açúcar que seu marido mandara do Brasil";,;29 "Procuração passada por Tomé Gonçalves [1605], piloto, a António Afonso Sanches, irmão de Gaspar Afonso Sanches, este defunto, ex-morador na cidade de Lisboa, a Miguel Luís Vilas Boas, mercador, moradores em Vila do Conde, e a Tomé Álvares, mareante, morador na Póvoa de Varzim. Esta procuração substitui outra, prévia, passada a Gaspar Afonso Sanches, entretanto falecido, para cobrar de Pero de Galegos, mercador, morador na cidade de Lisboa, uma quantia de 39000 reais, relativa a quatro caixas de açúcar vindas do Brasil que foram vendidas na llha de São Miguel, por seu mandado e por intermédio de Tomé Álvares, mareante,

\footnotetext{
${ }^{426}$ Leonor Freire Costa. O Transporte no Atlântico e a Companhia Geral do Comércio do Comércio (1580-1663), op.cit. p. 302

${ }^{427}$ Idem. p. 298. 1606.

${ }^{428}$ Mercador que foi preso por estar ajudando os Milão na sua tentativa frustrada de fuga em ${ }^{429}$ ADP NOT Vila do Conde, $1^{\circ}$ cartório, 1 sr lv fls 52-53.
} 
morador na Póvoa de Varzim, por Manuel João, mareante, morador em Vila do Conde". ${ }^{430}$

No Livro de entrada e saída dos navios e urcas do porto de Pernambuco $^{431}$, entre 1596 a 1605, Henrique também é citado como carregador por Leonor Freire Costa, em Portugal, em 1592, de açúcar (cinco toneladas), vinho/azeite (quatro toneladas) e mercadoria não especificada ${ }^{432}$.

Há referência para que se cobrem letras de câmbio em Olinda, em 1597, e comprado açúcar com Manuel Cardoso de Milão. ${ }^{433}$ Sabemos também que Manuel Sanches foi caixeiro de Henrique Dias Milão na cidade de Lisboa e que era casado com uma sobrinha de Duarte Fernandes, ${ }^{434}$ outro destacado negociante de açúcar, coreespondente em Pernambuco de Miguel Dias de Santiago, descendente direto de Bento Dias de Santiago, um dos primeiros senhores de engenho de Pernambuco ${ }^{435}$ e mercador de grosso trato lisboeta.

Os negócios com João Nunes Correia não aparecem explicitamente, embora a proximidade entre os Dias de Milão e os Andrade fique bastante clara no episódio apontado anteriormente da assinatura da fiança para a soltura de João Nunes na casa de Rodrigo de Andrade, tendo sido Henrique Dias de Milão um de seus abonadores. Luís Mendes, do Porto, casado com a irmã de João e Henrique Nunes Correia, era um elemento extremamente ativo na rede

${ }^{430}$ ADP NOT Vila do Conde 1 cartório, 1 sr lv 11 fls 44v-46

431 José Antonio Gonsalves de Mello. Gente da Nação. Cristãos-novos e judeus em Pernambuco 1542-1654, op.cit, p. 15-17; José Antonio Gonsalves de Mello. “Os Livros das Saídas das Urcas do Porto do Recife," p. 33-34.

432 Leonor Freire Costa. O transporte no Atlântico e a Companhia Geral do Comércio do Brasil (1580-1663) Vol II. Apêndice IV. Lisboa: CNCDP. p. 80.

433 Procuração de Brígida Rodrigues, mulher e procuradora de Manuel Fernandes, piloto, moradores na Rua da Misericórdia, a Nicolau Ferreira, mercador, para que pudesse cobrar, em Olinda, capitania de Pernambuco, um conjunto de letras de câmbio, no valor total de 395550 reais, e do que recebesse, extraídos os gastos, ficasse com uma comissão de $25 \%$, devendo empregar os restantes $75 \%$ na compra de açúcar com Manuel Cardoso de Milão.

PT/ADPRT/NOT/CNVCD14/001/0021/00032 I/35/4 - 5.1121, fl 45-47v

${ }^{434}$ ANTT. Inquisição de Lisboa. Processo. 12493.

435 José Antonio Gonsalves de Mello. Gente da Nação. Cristãos-novos e judeus em Pernambuco 1542-1654. ... op. cit, p. 25-27. 
dos Nunes Correia, representando-os na cidade do Porto, onde vivia. ${ }^{436}$ Sua atuação nesse clã tinha grande destaque no comércio da pimenta e na empresa açucareira, e é neste último que encontramos elos de negócios entre as duas famílias: ${ }^{437}$ a família Rodrigues d'Evora, um dos dois maiores clãs mercantis da época e tampém asientistas. ${ }^{438}$ Seus correspondentes em Amsterdã em 1594 eram Duarte Saraiva e Manuel Nunes Veiga e em Hamburgo, Manuel Álvares.

Leonor Freire Costa os aponta como carregadores presentes nos atos notariais respeitantes ao açúcar brasileiro em Lisboa e no Porto. São citados Fernão Lopes Milão (1599, açúcar e pau), Francisco de Cáceres (1617, 1627, 1628, açúcar), Henrique Dias de Milão (1592, açúcar), João Moreno (1596, 1600, 1604, vinho, açúcar, escravos, cargas de armação), Pero de Galegos (1596, vinho, açúcar). ${ }^{439}$ Os arquivos notariais de Vila do Conde nos informam, por meio de procurações, das transações com a compra e venda de açúcar de Pero de Galegos e Henrique Dias de Milão. Rodrigo de Andrade, o cunhado de Henrique, além asientista era sócio, junto com seu filho Francisco de Andrade, de André do Couto, mercador que morava em Olinda entre 1593 e 1595 e era o terceiro maior exportador de açúcar para o Reino, tendo como seu correspondente em Lisboa o irmão Pero do Couto. Em 1609, o engenho São

\footnotetext{
${ }^{436}$ Silvia Ricardo. O comerciante João Nunes Correia... op. cit. p, 132.
}

437 Nessa procuração de 1600, encontramos interligadas as famílias Nunes Correia (Luís Mendes), Anjo e Dias de Milão, todas envolvidas no referido encontro para a libertação de João Nunes Correia em Lisboa, representando a mais alta mercancia do período (1593). Procuração passada por Pedro Gonçalves, tanoeiro, morador em Vila do Conde, a Jorge Domingos, mercador, morador na freguesia de São Pedro de Avioso, termo do Porto, para que possa receber de Luís Mendes, mercador; morador no Porto, 20000 reais, de uma letra que sobre ele passou Manuel Fernandes Anjo, de Lisboa que a repassou a Henrique Dias de Milão. PT/ADPRT/NOT/CNVCD14/001/0022/00020 I/36/4 - 6.1022, fl 20v-21

${ }^{438}$ ANTT. Inquisição de Lisboa, processo 1491.

${ }^{439}$ Idem. p.49-111. 
João, na margem direita do Garjaú, ${ }^{440}$ em Pernambuco, era de sua propriedade. $^{441}$

“Procuração de António Dias Pachão [1606], piloto, a Pedro Gonçalves, barbeiro, para que vá a Lisboa, receber de Henrique Dias Milão, aí morador, em Alcântara, 100.000 reais, valor de que tinha passada letra a pagar por Francisco Nunes Ximenes, morador no Porto, que não a aceitou, tendo-a recambiado." 442

As transações entre a parentela se confirmam com Manuel de Galegos, filho de Pero de Galegos, de quem era correspondente que morou na Bahia, na casa de um cunhado seu, o comerciante Simão Nunes de Matos. ${ }^{443}$ Simão, também comerciante e senhor de engenho, tinha um irmão de nome Manuel Nunes Matos, genro de Henrique Dias Milão, que consta como fiador da Urca Anjo Gabriel, que, em 1596, partiu de Pernambuco destinada à Viana do Castelo, sendo também fiador e carregador de outra urca em $1597 .^{444}$ Um dos correspondentes dos Milão era Manoel Homem de Carvalho, mercador, na ratificação de sua confissão na Segunda Visitação do Santo Ofício ao Brasil, em 1620, perante o visitador Marcos Mendonça, diz ter se tornado judeu em Amsterdã, quando da sua estada em Amsterdã, em 1612, por influência de Simão Nunes de Matos, Fernão Lopes de Milão, Jerônimo Henriques e Manuel

${ }^{440} \mathrm{Na}$ margem oposta estava situado o Engenho de Santo Agostinho, de propriedade de João Nunes de Matos, irmão de Manoel Nunes de Matos, genro de Henrique Dias de Milão, casado com Ana de Milão. Evaldo Cabral de Mello. O Bagaço da Cana: os Engenhos de Açúcar do Brasil Holandês. São Paulo: Peguin: Cia das Letras, 2012, p.112.

${ }^{441}$ Evaldo Cabral de Mello. O Bagaço da Cana: os Engenhos de Açúcar do Brasil Holandês. São Paulo: Peguin: Cia das Letras, 2012, p.112.

${ }^{442}$ ADP Not V Conde 1 cart 1 sr Iv 24 fl 52

${ }^{443}$ Eduardo d'Oliveira França, Sonia A. Siqueira. op.cit p. 171; Denunciações da Bahia de 1618, p. 175. Manoel Homem e Antonio Mendes.

444 José Antônio Gonsalves de Mello. "Os Livros das Saídas das Urcas do Porto do Recife, 1595-1605”. Revista do Instituto Arqueológico, Histórico e Geográfico Pernambucano. Recife, 1993, p. 21-145. 
Sanches, filhos de João Luis Henriques, residentes naquela data em Pernambuco. ${ }^{445}$ Deslocou-se a mando de Pero de Galegos, por ordem de Jerônimo Henriques, para Hamburgo, Ilha da Madeira, Angola e para o Brasil, sempre ligado ao trato. Foi preso pela Inquisição em Angola, de onde tratava de interesses de Pero de Galegos. ${ }^{446}$ Seu sogro era Diogo Lopes,corrrespondente de Pero de Galegos na Madeira. ${ }^{447}$

Estavam também ligados ao tráfico negreiro, tendo sido Rodrigo de Andrade contrador de escravos, juntamente com Jorge Solis e d'Elvas. O irmão de Henrique, Antônio Dias de Cáceres, que vivia no México, quando prenderam a família em Lisboa, tinha vindo da Inglaterra e se dirigia a Angola, onde trataria da compra de escravos. ${ }^{448}$ De outra feita, Pero de Galegos tinha como seu correspondente na Madeira Diogo Lopes, um seu aparentado. Em uma viagem que este trazia carga de Flandres para os Nunes de Matos, senhores de engenho na Bahia e Pernambuco, respectivamente, foi para Angola, buscar escravos e levá-los ao Brasil. ${ }^{449}$

A interligação entre as casas comerciais mais proeminentes era comum e recorrente. As redes, como vimos, não eram estáticas e fechadas em si mesmas, e sim regidas pela dinâmica econômica num movimento ora convergente, ora divergente de interesses, com forte atuação da concorrência entre eles. ${ }^{450}$

A ausência de contratos entre os mercadores de Lisboa não permite confirmar as transações comerciais, mas uma fonte confiável são as letras de

${ }^{445}$ Antonio José Saraiva. Inquisição e cristãos-novos. Lisboa: Estampa, 1994, p. 182s; Eduardo d'Oliveira França, Sonia A. Siqueira. op.cit p. 507.

${ }_{446}$ ANTT. Inquisição de Lisboa. Processo.

${ }^{447}$ Eduardo d'Oliveira França, Sonia A. Siqueira. op.cit. p. 248.

${ }^{448}$ ANTT. Inquisição de Lisboa. Processo 6677.

249.

449 Eduardo d'Oliveira França, Sonia A. Siqueira. Denunciações de Pernambuco, op. cit. p.

${ }^{450}$ Daniel Strum. The Portuguese Jews and New Christians in the Sugar Trade., op.cit, p. 238. 
câmbio, nas quais podemos identificar muitas das relações econômicas que envolviam os comerciantes de grosso trato. Na procuração passada no Porto fica explicitada a relação comercial entre Luis Mendes, do Porto, Manuel Fernandes Anjo, de Lisboa, e Henrique Dias, de Milão: "Procuração passada por Pedro Gonçalves, tanoeiro, morador em Vila do Conde, a Jorge Domingos, mercador, morador na freguesia de São Pedro de Avioso, termo do Porto, para que possa receber de Luís Mendes, mercador, morador no Porto, 20.000 reais, de uma letra que sobre ele passou Manuel Fernandes Anjo, de Lisboa, que a repassou a Henrique Dias de Milão" ${ }^{451}$ Em outra procuração, Manuel Nunes de Matos, em 1600, quando morador em Olinda, emitiu uma letra de câmbio, sendo o sacado, o mesmo Luís Mendes ${ }^{452}$ e também a João Moreno. ${ }^{453}$

${ }^{451} \mathrm{PT} / \mathrm{ADPRT}$ /NOT/CNVCD14/001/0022/00020 I/36/4 - 6.1022, fl 20v-21

452،"Procuração passada por Isabel de Oliveira, viúva de Manuel Gonçalves, piloto, patrão da ribeira de Pernambuco, a António Dias Rendufe, para receber de Luís Mendes, mercador e morador na cidade do Porto, 35000 reais de uma letra que tem aceitem e que sobre ela passou Manuel Nunes de Matos, estante em Olinda, capitania de Pernambuco" PT/ADPRT/NOT/CNVCD14/001/0022/00053 $\mathrm{I} / 36 / 4-6.1022$, fl 63 .

${ }^{453}$ Reconhecimento, por Francisco de Brito, mercador, morador em Vila do Conde, de que Luis Mendes, mercador, morador no Porto, lhe pagara 120400 reais referentes a uma letra que passara João Moreno, mercador, morador na vila de Olinda, capitania de Pernambuco. Esse dinheiro fora-lhe pago com base numa carta de aviso referente a esse pagamento, sem que as respectivas letras tivessem ainda chegado ao Reino, nem haver notícias dos navios em que foram enviadas. Assume o outorgante o compromisso de lhe devolver o referido dinheiro, como dinheiro de mercador a mercador, se as letras não chegassem dentro de um ano.

ADP I/36/4 - 4.1015, fl 88-89

${ }^{453}$ PT/ADPRT/NOT/CNVCD14/001/0022/00020 I/36/4 - 6.1022, fl 20v-21

453،"Procuração passada por Isabel de Oliveira, viúva de Manuel Gonçalves, piloto, patrão da ribeira de Pernambuco, a António Dias Rendufe, para receber de Luís Mendes, mercador e morador na cidade do Porto, 35000 reais de uma letra que tem aceite e que sobre ela passou Manuel Nunes de Matos, estante em Olinda, capitania de Pernambuco" PT/ADPRT/NOT/CNVCD14/001/0022/00053 I/36/4 6.1022 , fl 63

${ }^{453}$ Reconhecimento, por Francisco de Brito, mercador, morador em Vila do Conde, de que Luis Mendes, mercador, morador no Porto, lhe pagara 120400 reais referentes a uma letra que passara João Moreno, mercador, morador na vila de Olinda, capitania de Pernambuco. Esse dinheiro fora-lhe pago com base numa carta de aviso referente a esse pagamento, sem que as respectivas letras tivessem ainda chegado ao Reino, nem haver notícias dos navios em que foram enviadas. Assume o outorgante o compromisso de lhe devolver o referido dinheiro, como dinheiro de mercador a mercador, se as letras não chegassem dentro de um ano.

ADP I/36/4 - 4.1015, fl 88-89 


\section{Capítulo 3}

\section{A ação mercantil dos Milão em Amsterdã, Antuérpia, e Hamburgo}

A comunidade sefardita de Amsterdã derivou do comércio ibérico e era composta por membros cristãos-novos das principais famílias integrantes das redes de comércio. Esses clãs familiares atuavam nos principais negócios do trato colonial e tinham feito fortuna principalmente nas derradeiras décadas do século XVI. Nesse período, muitas delas estavam ligadas ao comércio do açúcar, que prosperava no Nordeste do Brasil, consolidando fortunas das famílias cristãs-novas. ${ }^{454} \mathrm{O}$ consumo dessa mercadoria crescia na Europa e a as redes necessitavam se ampliar, incorporando novas praças ou incrementando as já existentes.

Jessica Vance Roitman fez um estudo aprofundado sobre as redes de comércio, focada em três grandes mercadores cristãos-novos estabelecidos em Amsterdã: Bento Osório, Manoel Carvalho e Manoel Rodrigues Veja, ${ }^{455}$,no qual apresenta farta documentação notarial e arquivística sobre as transações mercantis desses líderes do trato e suas conexões com sefarditas e parceiros fora desse grupo. Para ela, as redes de comércio sempre foram abertas, e as associações desses grandes empreendedores comprovam essa hipótese.

Cristopher Ebert analisa o comércio do açúcar e mercadores em Pernambuco, Amsterdã, Portugal, Hamburgo, incluindo seus negócios, baseando-se nos arquivos notariais e municipais de Amsterdã, Roterdã, Haia, além de processos inquisitoriais. Ebert faz uma análise dos comerciantes, não

\footnotetext{
454; Jonathan Irvine. Dutch Primacy in World Trade, op.cit.

${ }^{455}$ The Same but Different? Inter-cultural Trade and the Sephardim, 1595-1640, op.cit.
} 
só cristãos-novos e judeus, mas todos os envolvidos nas trocas, inclusive, holandeses e alemães.

Daniel Swetschinski trabalha a migração portuguesa ${ }^{456}$ cristã-nova no século XVII para Amsterdã, abordando aspectos econômicos daqueles que se fixaram em Amsterdã. Jonathan Israel, que entende que a ascensão da elite comerciante em Amsterdã não se deu pela presença de um determinado grupo de imigrantes, mas pelo fato de ter uma economia que estava mais estruturada ${ }^{457}$.

Os estudos sobre as redes de comércio que tratam da mescla entre cristãos-novos e cristãos-velhos, como o de David Grant Smith em The mercantile class of Portugal and Brazil in the seventeenth century (1620$1690)^{458}$, que trabalha as redes de comércio de 1620 a 1690 na Bahia, e o de Cátia Antunes em Globalisation in the Early Modern Period: the economic relationship between Amsterdam and Lisbon (1640-1705), ${ }^{459}$ as relações entre mercadores e suas redes entre Lisboa e Amsterdã, concluem que as redes de comércio não eram étnicas, sendo abertas, havendo tanto cristãos-novos quanto cristãos-velhos. O período ao quais ambos dedicaram suas pesquisas é posterior ao nosso, quando já havia nova configuração no reino português, com a Restauração (1640), os holandeses estiveram no Nordeste açucareiro entre 1630 e 1654, invadido pela Companhia das Índias Ocidentais (WIC), de capital holandês, e a Inglaterra já se firmava como potência mercantil europeia.

\footnotetext{
${ }^{456}$ Daniel M. Swetschinski. Reluctant Cosmopolitan: Portuguese Jews of Seventeenth Century in Amsterdam, op.cit.

457 Jonathan Irving Israel. Dutch Primacy in World Trade 1585-1740, op. cit. p. 214.

${ }^{458}$ David. Grant Smith. The mercantile class of Portugal and Brazil in the seventeenth century (1620-1690), op.cit.

${ }_{459}$ Cátia Antunes. Globalization in the early Modern Period: the economic relationship between Amsterdam and Lisbon (1640-1705), op. cit.
} 
A principal fonte sobre os cristãos-novos e judeus em Amsterdã e suas atividades econômicas está em Studia Rosenthaliana, os registros dos cartórios notariais de Amsterdã a partir de 1595 a 1639 relativos à comunidade mercantil portuguesa radicada na cidade. Não se trata de simples registros, pois por meio deles há uma variedade imensa de informações sobre as relações comerciais entre a Gente da Nação, compra de açúcar, relações entre os mercadores e os flamengos, e entre a comunidade sefardita, as redes de comércio, os casamentos realizados, entre muitas outras informações. Essa fonte traz mais de 800 portugueses em Amsterdã, mesmo que citados esporadicamente, cerca de 500 em Portugal e 136 no Brasil, e muitos outros em vários lugares.

A consulta à Segunda Visitação feita à Bahia entre os anos de 1618 e 1620 nos traz informações contidas nos depoimentos de cristãos-novos residentes em Pernambuco e Bahia, ou mesmo daqueles que estavam na Colônia, mas não eram residentes, sobre os que se estabeleceram em Amsterdã. A leitura de processos inquisitoriais nos possibilita identificar muitos dos mercadores cristãos-novos ou judeus citados nas fontes anteriores, até sua fixação em Amsterdã e relações parentais entre eles, como também comerciais. Dessa forma, foi possível cruzar as informações levantadas, principalmente sobre os mercadores ligados ao comércio do açúcar em Pernambuco e cristãos-novos saídos de Pernambuco que se estabeleceram em Amsterdã. 


\subsection{A vida em Amsterdã}

Depois que a família Milão evadiu-se de Portugal, fugindo do bairro penitencial, seus integrantes fixaram-se em Amsterdã e Hamburgo. Em Amsterdã, Gomes Rodrigues de Milão se assumiu judeu com o nome de Daniel de Olanda e comandava a rede de comércio da família. ${ }^{460}$ Em Hamburgo, Álvaro Dinis, casado com Beatriz Henriques, era o mais rico e um dos mais importantes comerciantes da cidade. ${ }^{461} \mathrm{~A}$ expansão da rede alcançou Londres, que passou a assumir lugar de maior destaque nas transações comerciais com a fixação na cidade de agentes familiares próximos, no caso específico, Manuel Nunes de Matos, genro de Henrique Dias de Milão. ${ }^{462}$ Ele foi ao encontro do cunhado Paulo Cardoso de Milão, de Francisco de Cáceres, tio paterno de Paulo, e de seus filhos, que eram expoentes no trato, aliado aos riquíssimos Carvajal, vindos do México. ${ }^{463}$ Em Antuérpia estavam estabelecidos os filhos de Ana de Milão e Rodrigo d'Andrade, Jorge e André Rodrigues d'Andrade. ${ }^{464}$

Os holandeses tinham tradição no comércio marítimo no Báltico e com Portugal também. Eles negociavam nos portos do norte do Reino português, no Porto e em Viana do Castelo, pau-brasil, açúcar, tecidos, móveis, mantimentos e serviços de transporte marítimo. Segundo Pieter Emmer, ${ }^{465}$ a procura por sal e açúcar foi importante para que os holandeses acabassem chegando ao Atlântico e desenvolvessem ainda mais suas atividades mercantis.

${ }^{460}$ Studia Rosenthaliana 351; Hermann Pris Salomon. The Portrait of a New Christian, op, cit. p. 132 .

${ }^{461}$ Florbela Veiga Frade. O Trato e a Família, op.cit, p. 245-249.

${ }^{462}$ Studia Rosenthaliana 634; ANTT. Inquisição de Lisboa. Processo 10.600.

${ }^{463}$ Cecil Roth, A History of the Jews in England, London: Oxford, 1964.

${ }^{464}$ Studia Rosenthaliana 644.

465 Pieter Emmer. O comércio holandês do sal e do açúcar, 1585-1650. Anais do I Seminário Internacional sobre o sal português. Porto, Aveiro, 27-29 maio 2004. 
Alemães, ingleses e portugueses eram bem-vindos a Amsterdã, visto que, no começo do século XVII, era o grande entreposto europeu que abastecia a Europa e o local que mais oferecia oportunidades de negócios. Com a queda de Antuérpia nas mãos dos espanhóis, em 1585, Amsterdã passou a concentrar o recebimento de açúcar que seria enviado ao Norte Europeu, recebendo também grupos de mercadores saídos daquela praça, como também de Lisboa e do Porto. Atraía comerciantes com conhecimentos financeiros necessários a seu novo papel de centro econômico em expansão e entre esses se encontravam muitos judeus e cristãos-novos com grande experiência no comércio de produtos coloniais, especialmente o açúcar.

Abriam-se oportunidades sem precedentes para comerciantes abastados que tinham os meios, as conexões e a visão tirar partido das novas possibilidades do trato. Os recém-chegados davam grandes contribuições às novas frentes de comércio direto com a Rússia e com a África Ocidental, o que requeria mais capitais, conexões, transporte, pessoas e também maiores riscos e mais lucros. Os mercadores de Amsterdã, embora focados em determinados tipos de negócio, mantinham suas redes de comércio atreladas aos mais lucrativos ramos do trato. Aparecem ligados à empresa açucareira, ao tráfico, à pimenta, aos diamantes e estavam presentes nas principais praças do comércio internacional.

O açúcar se popularizara como também outros produtos coloniais em um mercado em expansão. Eram comercializados têxteis, açúcar e especiarias, armas e munições, produtos de ferro, joias e pedras preciosas, escravos, paubrasil, coral, marfim, corantes, laca, cera, veludo, seda, frutas, pastel, vinho, cereais, feijão, outros tipos de alimentos, madeira, couros, metalurgia, sal e 
cordas. ${ }^{466}$ As trocas com diamantes e joias, tecidos como o tafetá, o veludo e a seda trazidos do Oriente ${ }^{467}$ tomaram impulso nas duas primeiras décadas do século XVII e abasteciam a nobreza, as casas reais e abastadas famílias enriquecidas europeias.

Os motivos para a emigração, como já vimos, dos sefarditas para os pontos da Europa podiam estar ligados às perseguições da Inquisição, porém, oportunidades econômicas sempre desempenharam um papel importante na decisão sobre onde se instalar. A ascensão e a riqueza holandesa estariam relacionadas, segundo Braudel, ao desenvolvimento do transporte de mercadorias por volta de 1590 - essa evidência é, sem dúvida, uma questão fundamental para a compreensão da primazia dos holandeses no século XVII. ${ }^{468}$ Jonathan Irvine Israel alerta para modificações políticas, como a captura da Antuérpia ou os sucessivos embargos decorrentes da guerra de independência das Províncias Unidas, como se esses não tivessem influência sobre o comércio holandês. ${ }^{469}$

Apesar de o açúcar brasileiro ser direcionado em maior quantidade para Amsterdã, Antuérpia continuou sendo um importante porto receptor desse produto brasileiro, atrás de Amsterdã e à frente de Hamburgo, na distribuição do açúcar na Europa, embora grande parte do que ia para Hamburgo fosse reexportado via Amsterdã. Essas três cidades juntas absorveram ao menos $75 \%$ das importações brasileiras de açúcar. ${ }^{470}$ Havia uma intensa relação comercial entre Hamburgo e Amsterdã, o que resultava mais em uma parceria do que rivalidade, visto que Hamburgo dependia muito das importações de

\footnotetext{
${ }^{466}$ Jessica Vance Roitman. The Same but Different? Op.cit. p. 173-192.

${ }^{467}$ James C. Boyajian. Portuguese Trade in Asia under the Habsburgs, op. cit.166-172.

${ }^{468}$ Fernand Braudel. Civilização Material, Economia e Capitalismo. op cit.

${ }^{469}$ Jonathan I. Israel. Dutch Primacy in World Trade 1585-1740, op.cit. p. 80.

${ }^{470}$ Florbela Veiga Frade. O Trato e a Família, op. cit, p. 282- 292.
} 
Amsterdã. Essa proximidade foi importante para que Hamburgo se estabelecesse como líder na redistribuição das mercadorias para o extremo norte da Europa e no domínio do comércio do Báltico.

A cidade se configurou como centro financeiro, em especial aos financiamentos para os seguros de viagem, entreposto das mercadorias do norte da Europa rumo a Portugal e principal distribuidor do açúcar brasileiro. No entender de Jonathan Irvine Israel: “[...] Não havia nenhum grupo entrincheirado barrando o caminho para a ascendência sefardi no comércio de açúcar de Amsterdam; pelo contrário, havia apreciação desse novo trunfo por parte dos dirigentes da cidade. O crescimento das importações de açúcar, o carro-chefe do comércio sefardi holandês, durante a Trégua dos Doze Anos, foi tanto que mais de vinte novas refinarias de açúcar foram estabelecidas em Amsterdã no espaço de 10 ou 12 anos". ${ }^{471}$

Com a expansão do comércio de mercadorias e das cargas, surgiu a necessidade de novos serviços complementares às atividades mercantis, tais como corretagem e seguros. O Exchange Bank, por exemplo, foi criado em Amsterdã em $1609^{472}$ e logo se tornou um local onde os mercadores passaram a fazer suas transações financeiras, contribuindo para o crescimento das atividades ligadas ao transporte naval.

\subsection{As conexões das redes}

A ligação entre os cristãos-novos do Nordeste açucareiro se fortaleceu com a comunidade judaica de Amsterdã. As famílias tinham seus agentes nos

${ }^{471}$ Jonathan I. Israel Empires and Entrepots: The Dutch, the Spanish Monarchy and the Jews, 1585-1713. op. cit, p. 422.

472 Jonathan I. Israel. Dutch Primacy in World Trade 1585-1740, op. cit. p. 82. 
centros produtores de açúcar que lhes davam acesso aos financiamentos e aos seguros marítimos necessários à continuidade e prosperidade comercial.

Os diamantes já eram trazidos da Índia, da China e das Filipinas até Lisboa desde $1580 .^{473}$ De Lisboa, os diamantes eram levados a Antuérpia, que se tornou o principal centro de distribuição de pedras preciosas da Europa, embora a lapidação se desse em Amsterdã. O contrabando era muito fácil e, por isso, uma inspeção pouco usual na Casa da Índia, em Lisboa, onde os diamantes eram descarregados da rota Goa-Lisboa, revelou uma grande fraude em duas embarcações que estavam registradas em nome de dois flamengos, muito conhecidos e constantes associados em negócios dos cristãos-novos em Amsterdã. Foi encontrada uma grande quantidade de diamantes que pertenciam a vários cristãos-novos lisboetas e não estavam registrados, sendo, portanto, contrabandeados. Descobriu-se também que o navio pertencia ao consórcio da elite dos mercadores de Lisboa, com negócios no Oriente, escravos, açúcar e outros produtos coloniais.

\subsection{Gente da Nação}

Desde a década de 1590, os cristãos-novos passaram a migrar para Amsterdã, e com eles seus capitais. Os primeiros foram James Lopes da Costa (Jacob Tirado) e Duarte Saraiva (Duarte Senior Coronel), ligados ao trato do açúcar, tendo eles morado em Pernambuco. ${ }^{474}$

Os comerciantes que se estabeleciam em Amsterdã eram membros de integrantes de redes comércio com atuação transcontinental e ligados aos

\footnotetext{
${ }^{473}$ James C. Boyajian. Portuguese Trade under the Habsburgs, op. cit, p. 232.

${ }^{474}$ José Antonio Gonsalves de Mello. Gente da Nação, op. cit, p.38-39.
} 
principais negócios coloniais da época: açúcar, prata, tráfico negreiro, pimenta. A riqueza relativa que um comerciante trazia com ele para Amsterdã talvez fosse menos importante do que seus contatos ou sua participação na rede de comércio a qual pertenciam. Era ela, a rede de comércio, que permitia multiplicar os negócios e oportunidades para a contínua acumulação de riqueza. A riqueza, portanto, poderia não ser tão importante quanto a rede de comércio do qual já era membro. A importância do indivíduo era reconhecida dentro de seu círculo étnico e parental e se transportava para a esfera econômica. As relações estabelecidas nesses círculos preexistentes eram os motores geradores das novas conexões que permitiam o alargamento das próprias redes. Os agentes e seus contatos geravam novas oportunidades de negócios. Amsterdã contava com refinarias de açúcar e grande parte do açúcar brasileiro foi refinado ${ }^{475}$ nessa cidade antes de ser exportado.

Era necessário ampliar as conexões para a promoção do comércio com o qual estavam envolvidos. No entender de Jessica Roitman, esses grandes comerciantes do Norte da Europa exploravam as oportunidades ${ }^{476}$ que thes apareciam para obter vantagens comerciais no curto prazo. Muitas das novas alianças comerciais que se concretizavam podiam ser feitas para um empreendimento como a divisão de carga de um navio, a sociedade em uma viagem marítima, um fretamento. Outras vezes, as alianças podiam ser mais duradouras e ocorrer parcerias constantes. Manuel Cardoso de Milão fez um contrato de fretamento para uma única viagem, conforme consta nos arquivos notariais de Amsterdã. "Manuel Cardoso, português comerciante em Amsterdã, e capitão Claes Cornelisz, de Hoorn, para uma viagem do navio De Fortuijn. O melaço.

${ }^{475}$ Refino consistia essencialmente obter o açúcar cristalizado, removendo o máximo de ${ }^{476}$ Jessica Roitman. The Same but the Different? op. cit. p. 34-39. 
navio estava a navegar em lastro de Amsterdã para Dantzig (Gdansk) e de lá para Aveiro com trigo e centeio em uma carga de 6 ducados por último, com o ducado de 3 florins." 477

Esses importantes homens do trato diversificavam suas atividades e se engajaram em novos empreendimentos. Passaram a agregar novos associados, incorporando outros grupos a suas próprias redes, e se integraram a outras redes, incluindo a dos comerciantes da diáspora portuguesa no estrangeiro. Os mercadores que estavam em Amsterdã, Hamburgo, Antuérpia e Londres todos eram imigrantes e frutos da diáspora.

Basicamente esses grandes comerciantes tinham vivido em múltiplos lugares no curso de suas carreiras por causa do trato. Ao longo de suas vidas, cruzaram com muitos mercadores e tinham muitos conhecimentos, que, sem dúvida, era o seu maior cabedal. Desse conhecimento, podiam traçar suas estratégias comerciais e as decisões de quem agregar às suas redes. Os negócios se ampliavam em termos geográficos, quantitativos e qualitativos. A diversificação dos negócios era característica dos comerciantes cristãos-novos, que investiram seus cabedais nas especiarias do Oriente, no Nordeste açucareiro, no comércio de escravos e na prata da América espanhola. A diversificação de seus investimentos era uma forma de manter grande a possibilidade de ganhos elevada, visto que dificilmente os quatro ramos apresentariam problemas simultaneamente.

Amsterdã cresceu muito com a presença dos sefarditas. A ação inquisitorial continuou altamente repressiva findado o Perdão Geral de 1605, o que favoreceu a participação dos judeus estabelecidos em Amsterdã nas

${ }^{477}$ Studia Rosenthaliana 543. 
trocas que foram incrementadas entre Brasil e Portugal e entre Portugal e Holanda na década de 1610. Para Swetschinski, esse aumento estava relacionado à dura ação do Santo Ofício, visto que seus correspondentes no Porto estavam presos, centralizando suas ações e buscando novos parceiros, mesmo que por breve período de tempo. ${ }^{478}$

Sabemos que os bens dos Milão foram confiscados pela Inquisição e que eles saíram fugidos de Portugal, portanto sem levar bens materiais para Amsterdã e Hamburgo. O período de prisão da família foi de aproximadamente três anos e de quase dois anos o cumprimento da sentença no bairro penitencial. ${ }^{479}$ É razoável pressupor que a ausência de importantes membros nesse período de tempo seria suficiente para causar danos à dinâmica de funcionamento da rede ou mesmo provocar seu desmantelamento. Naquela época, as dificuldades como a fragilidade e a dificuldade nas comunicações, a distância entre locais onde as mercadorias eram adquiridas e os mercados, intempéries climáticas, pirataria e o corso, negócios malsucedidos concorriam para que bancarrotas se sucedessem com certa facilidade. ${ }^{480}$

No entanto, a rede continuou funcionando apesar da prisão de parte de seus membros, inclusive de seu líder, Henrique Dias de Milão, e de sua morte pelo relaxamento na fé em 1609. As principais transações continuaram sendo feitas por Francisco de Cáceres no Porto, Pero de Galegos ${ }^{481}$ e João Moreno em Lisboa, Álvaro Dinis em Hamburgo, Manuel Nunes de Mattos em Amsterdã,

\footnotetext{
${ }^{478}$ Jonathan I. Israel. Diasporas within a Diaspora: Jews, Crypto-Jews and the World Maritime Empires (1540-1740). op. cit. p. 92-99.

${ }^{479}$ Henry Pris Salomon. The Portrait of a New Christian, op. cit. 76-81.

480 Jonathan I. Israel. Diasporas within a Diaspora: Jews, Crypto-Jews and the World Maritime Empires (1540-1740). op. cit, p. 104-117.

${ }^{481}$ Denunciações de Pernambuco.
} 
Manuel Cardoso de Milão e Antonio Dias Cáceres em Londres e Amsterdã e Hamburgo. ${ }^{482}$

A documentação nos indica que Gomes Dias de Milão/Daniel de Olanda já estava reintegrado à rede de comércio à qual pertencia em Amsterdã, em 1611, com papel de destaque no trato mercantil para Hamburgo, França, Espanha, Dunquerque, Dubrovnik, Portugal. ${ }^{483}$ Fernão Lopes Milão, que também se fixou em Amsterdã, deu continuidade às suas atividades mercantis, embora depois disso não se tenha encontrado mais referências a esse membro da família Milão. Quanto a Antonio de Milão, também só há uma referência a ele em Amsterdã como comerciante ${ }^{484}$ Gomes Dias de Milão reapareceu com o nome de Daniel de Olanda, ${ }^{485}$ e os registros notariais de Amsterdã o inserem na rede do qual fazia parte antes que fossem presos em 1606. Seus negócios, que foram amplificados, estavam associados aos diamantes, ao açúcar, aos seguros marítimos. ${ }^{486}$

James C. Boyajian aponta a família cristã-nova Faleiro/Teixeira como uma das mais importantes no trato português no final do século XVI e início do século XVII. ${ }^{487}$ Manuel Teixeira (Manuel Cardoso de Milão) casou-se com a irmã de Antonio Faleiro, grande investidor na Rota do Cabo, ligado aos Solis e aos Tinocos, além de comerciar diamantes via Veneza, sendo um dos mais prósperos. ${ }^{488}$ Manuel aparece em Amsterdã, mudando-se para Londres, e depois em Hamburgo, onde seus cunhados eram grandes mercadores. ${ }^{489}$

\footnotetext{
${ }^{482}$ ANTT. Inquisição de Lisboa. Processo 3068.

${ }^{483}$ Studia Rosenthaliana 604.

${ }^{484}$ Studia Rosenthaliana 724.

${ }^{485} \mathrm{Na}$ documentação da Studia Rosenthaliana, aparece ora como Gomes Dias de Milão, ora

${ }^{486}$ Studia Rosenthaliana.986.

${ }^{487}$ James C. Boyajian. Portuguese trade in Asia under the Habsburgs, op cit., appendix 14-A.

${ }^{488}$ ANTT. Inquisição de Lisboa. Processo 13013.

${ }^{489}$ Studia Rosenthaliana.653.
} como Daniel de Olanda. 


\subsubsection{Hamburgo}

Ao mesmo tempo, Álvaro Dinis já estava em Hamburgo desde 1605, homem de grande riqueza, líder da comunidade judaica em termos econômicos e espirituais que se expandia em Hamburgo, como já vimos anteriormente. Grande exportador de grãos, redistribuía o açúcar brasileiro e mantinha ativo comércio com o sal do norte de Portugal. A nova comunidade sefardita se formou baseada em um clã familiar por Álvaro Dinis, que se chamava Samuel Jachia, enquanto Paulo de Milão assumiu-se como Daniel Abensur. António Dias Milão tornou-se Josua, ou Paulo Diederisen, ou Osua Abensur. ${ }^{490}$ Antônio Faleiro, primo do contratador rico que foi de Lisboa, passou a chamar-se Abraão Aboab, seu irmão, André Faleiro, Jacob Aboab, e eram filhos de Manuel Teixeira, nome judaico de Manuel, e de uma prima, filha de Rodrigo de Andrade e Ana de Andrade. ${ }^{491}$ Em 1611, foi um dos três signatários do contrato para a construção do cemitério judaico de Altona, próximo a Hamburgo, e tinha forte liderança na comunidade judaica que se estabeleceu e crescia nesse porto do Báltico.

Álvaro Diniz foi o responsável pela expansão do trato de Hamburgo até Lubeck e os Estados bálticos. Dinis recebeu concessões especiais para 0 comércio ibérico e foi um dos incentivadores para que judeus se estabelecessem na cidade onde vivia. Juntamente com ele estavam seus cunhados Paulo de Milão e Pero de Palácios, este concunhado, casado com Isabel Rodrigues. Tornou-se conselheiro do rei e um pouco mais tarde foi nomeado mestre da Casa da Moeda. Em 1617, em virtude de problemas na cunhagem das moedas, foi obrigado a deixar Hamburgo junto com a família e o

\footnotetext{
${ }^{490}$ José Maria Abecassis. Genealogia Hebraica: Portugal, e Gibraltar, séc. XVII-XX.Lisboa: José Maria Abecassis, 1990-1991.V 3. p. 135-152.

${ }^{491}$ ANTT. Inquisição de Lisboa. Processo 4481-1.
} 
cunhado Paulo de Milão (Paulo Diederisen) e foi para Altona e depois para Glüeckstadt. Voltou para Hamburgo e retomou suas funções, sem nunca ter deixado a mercancia e ser um dos seus mais expressivos representantes no Báltico. ${ }^{492}$

Em 1608, trouxe para Hamburgo seu cunhado e correspondente em Lisboa, Henrique de Lima, ${ }^{493}$ que, em 1612, aparecia como importador de açúcar nos registros da cidade de Hamburgo e associado de Álvaro Dinis.

Nas primeiras décadas do século XVII, três famílias cristãs-novas entrelaçadas dominavam o trato em Hamburgo: a de Álvaro Dinis, a de Ruy Fernandes Cardoso e a de Rodrigo Pires Brandão, ${ }^{494}$ tendo sido Ruy Fernandes Cardoso e Álvaro Dinis os dois maiores importadores desse produto no ano de $1612 .{ }^{495}$ Gonçalo tinha como seu correspondente no Brasil, seu filho Diogo da Fonseca e seu irmão era seu correspondente em Lisboa. ${ }^{496}$ Francisco de Cáceres era correspondente de Álvaro Dinis no Porto. ${ }^{497}$

Embora não houvesse total liberdade religiosa em relação aos judeus, o conselho da cidade de Hamburgo seguiu uma política utilitarista de (relativa) tolerância religiosa para os comerciantes judeus portugueses, visto que esses podiam trazer vantagens econômicas. Os sefarditas em Hamburgo, por exemplo, foram pioneiros no estabelecimento do comércio com Espanha e Portugal, movimentando significativamente a vida econômica desse porto do Báltico. Passaram a ser desembarcados açúcar, tabaco, especiarias, algodão e

\footnotetext{
492 Idem.

493 José Maria Abecassis. Genealogia Hebraica: Portugal, e Gibraltar, séc. XVII-XX.Lisboa: José Maria Abecassis, 1990-1991.V 3. p. 135.

${ }^{494}$ Christopher Ebert.Betwwen .op.cit. p,202

495 Idem, p 204.

${ }^{496}$ Ibidem.

${ }^{497}$ ANTT. Inquisição de Lisboa. Processo 3068.
} 
outros produtos coloniais ${ }^{498}$ e seguiam rumo à Península lbérica grãos, armas. Além disso, eles desempenharam um papel importante na fundação do Banco de Hamburgo.

Francisco de Palácios, sobrinho de Álvaro Dinis, é um exemplo da amplidão das redes comerciais, bem como de sua composição. Em 1620, com 21 anos, ele seus irmãos Pedro e Jácomo Palácios viviam com o tio Álvaro Dinis como judeus em Hamburgo, onde, entre outras coisas, comerciavam açúcar brasileiro. Seu outro irmão, Duarte Palácios tinha negócios com a Índia, Sevilha e Hamburgo e residia agora em Amsterdã, onde vivia livremente como judeu. Em 1619, Francisco viajou a Hamburgo com licença do Conselho da Fazenda como agente de Andre Lopez, contratador de pau-brasil. Ele ia comprar grãos em troca da venda de madeira do Brasil. Como a transação não deu certo, ele saiu secretamente de Hamburgo e dirigiu-se para Amsterdã, e lá permaneceu por oito meses, até retornar a Lisboa Francisco de Palácios foi preso pela Inquisição em 1630, acusado de sodomia. ${ }^{499}$

\subsection{A importância do núcleo familiar}

Apesar do aumento da extensão geográfica do trato com a incorporação de novas praças e novas áreas, as redes de comércio cristãs-novas também estenderam seu raio de ação sem, no entanto, desconfigurar sua gênese. Em Amsterdã e Hamburgo os grupos mercantis permaneceram tendo na família e no casamento endogâmico o esteio de sua ação. Em Amsterdã foram estabelecidas regras para proteger a estrutura familiar e evitar casamento fora

\footnotetext{
${ }^{498}$ ANTT. Inquisição de Lisboa. Processo 8098.

499 ANTT. Inquisição de Lisboa. Processo 12068.
} 
do círculo sefardi, sendo a endogamia o recurso mais eficiente para garantir a conservação da família e da comunidade e impedir a infiltração de estranhos aos da "Gente da Nação". O parentesco era o suporte da atividade econômica e a associação dentro do marco familiar era a estrutura sobre a qual se davam os negócios e apoiando-se nela se introduziam os circuitos comerciais e financeiros ${ }^{500}$ A língua falada entre os da Nação era o português, como forma de manter a unicidade do grupo. ${ }^{501}$ Cátia Antunes em seu trabalho explana que o português era uma espécie de língua franca em toda Europa, embora se alternassem o português e o holandês. Grande parte dos contratos, dos registros e documentos foi feito em português, destacando-se casamentos e testamentos, lavrados nos cartórios notariais. ${ }^{502}$

Pela endogamia mantinha-se o grupo forte, era a forma de conservar as tradições e o passado, a identidade e a individualidade. As redes de comércio continuavam sendo mantidas e estruturadas nas mesmas bases anteriores. $O$ controle delas e o "núcleo", a liderança não se esvaiu e nem se repartiu. Os negócios, as associações entre os mercadores e as letras de câmbio mostram que os homens de grosso trato continuaram com os contratos e arranjos comerciais majoritariamente entre si, embora tenham abrindo a terceiros possibilidades de associação e parcerias comerciais.

O casamento endogâmico permaneceu entre os sefarditas em Amsterdã, Hamburgo e Antuérpia nas primeiras décadas do século XVII, não

\footnotetext{
500 Jonathan I. Israel. Diasporas within a Diaspora: Jews, Crypto-Jews and the World Maritime Empires (1540-1740). Op. cit.

${ }^{501}$ Mirian Bodian, Hebrews of the Portuguese Nation: Conversos and Community in Early Modern Amsterdam, Bloomington, 1999 p. 63

${ }^{502}$ Cátia Antunes. Globalization in the early modern period, op.cit, p. 145.
} 
só por motivos religiosos, visto que, depois que deixaram Portugal, os cristãosnovos que se estabeleceram nessas praças se assumiram judeus. ${ }^{503}$

Na família Milão temos Gomes Rodrigues de Milão que se casou com a prima coirmã Beatriz Rodrigues Cohen em Hamburgo. Isabel Rodrigues, a caçula de Henrique e Guiomar Milão, casou-se em Hamburgo com Pero (Pedro) Palácios, primo-irmão de Álvaro Dinis, que era seu cunhado, casado com sua irmã Beatriz Henriques. Paulo de Milão em Hamburgo contraiu núpcias com a irmã de Álvaro Dinis, Abigail Dinis, viúva de Gonçalo Lima, concunhado de Dinis. ${ }^{504} \mathrm{Em}$ Antuérpia, a família Ximenes que dominava a vida econômica da cidade há muitas décadas, contraiu matrimônio com outros poderosos clãs que lá residiam, como os D'Evora e os d'Andrade.

Na geração seguinte, duas netas do filho mais velho dos Milão, Manuel Cardoso de Milão, em Hamburgo Manuel Teixeira, filho de Gabriel Milão, casaram-se com os filhos de Paulo Milão que viviam em Hamburgo ${ }^{505}$.

Filhos eram introduzidos nos negócios e passavam a atuar de forma significativa na rede comercial à qual pertenciam. José Pinto e Simão Rodrigues de Cáceres, ${ }^{506}$ mercadores em Amsterdã, irmão e filho de Francisco de Cáceres, mercador do Porto, deram ao piloto uma declaração que seu irmão e pai não estavam informados que o navio De Hoope, pertencente a Engel Habet, na sua vinda do Rio de Janeiro para o Porto, foi capturado por piratas franceses. Ele fez outro seguro por 100 libras flamengas. O filho de Paulo Milão, Joshua Henriques, era um destacado membro da sociedade em Glückstadt, sendo o responsável pelo correio real.

${ }^{503}$ Daniel Strum. The Portuguese Jews and New Christians in the Sugar Trade, op.cit. p. 231143.

\footnotetext{
${ }^{504}$ Vide capítulo 2.

${ }_{505}^{505}$ ANTT. Inquisição de Lisboa. Processo 8032.

${ }^{506}$ Studio Rosenthaliana. 2303.
} 
Como seus ancestrais, os meninos eram mandados para serem iniciados e treinados por seus parentes no trato e depois assumirem postos onde os negócios exigiam. Assim se deu com o filho de Álvaro Dinis e Isabel Henriques, Rubens Henriques, que foi para Amsterdã com Daniel de Olanda e depois há registro dele em Curaçao, nas Antilhas Holandesas, ligado ao tráfico de escravos e à produção de açúcar no mar do Caribe ${ }^{507}$ na metade da centúria. Esse registro é importante porque, por meio dele, somos informados que a família continuava ligada ao negócio do açúcar e ao rentável tráfico negreiro.

Parte da família de Francisco de Cáceres se estabeleceu em Rouen, e fez lá um posto avançado de seus negócios e lá encontramos como agente seu filho, Antonio de Cáceres. ${ }^{508}$ Rouen, na segunda década do século XVII, foi crescendo em importância no comércio entre a África, onde eram compravam escravos e as colônias francesas do mar do Caribe, onde os escravos eram trocados por açúcar. A comunidade sefardita em Rouen jamais poderia se assumir judia em um país católico, mas supomos que dada a importância estratégica dessa praça comercial, os Cáceres lá se instalaram. Ela contava também com Jerônimo Nunes da Costa, o tio e os primos de Antonio de Cáceres e André Rodrigues Lamego. Entre 1627 e 1623, foram enviadas de Cabo Verde pelo Porto cerca de 1.873 caixas de açúcar; do Brasil, entre 1615 e $1623,1.989$ caixas. $^{509}$

${ }^{507}$ Joseph Ben Brith. Dye Odissee der Henrique Familie, op. cit, p, 56.

508 Studio Rosenthaliana 2333. "Pedro Gomes de Lisboa, mercador em Amsterdã, autoriza Pedro Dias, mercador em Rouen, a coletar várias opiniões sobre diferentes questões sobre Francisco de Cáceres, que estava na casa de seu filho, Antonio de Cáceres, e pedir explicações sobre algumas coisas para saber se eram verdades. "

${ }^{509}$ Leonor Freire Costa. O Transporte no Atlântico e a Companhia Geral do Comércio, op. cit, p. $167-168$. 
Simon Cáceres foi um dos principais comerciantes de Amsterdã, embora com passagem pelo Porto, e exista registro que sua família vivesse em Hamburgo e em Glückstadt. ${ }^{510}$ De Hamburgo, Simon fez com seu pai Francisco de Cáceres comércio com o Brasil, de onde principalmente importava açúcar, e tinha negócios com Álvaro Diniz e Duarte Palácios. ${ }^{511}$ Teve também ligações comerciais com o Porto português e em 1626 com Antonio Henriques ou Antonio de Milão em Rouen, conhecido como Abraham do Porto, um neto de Henrique, filho de Daniel de Olanda..$^{512}$

\subsubsection{Daniel de Olanda e Francisco de Cáceres}

Os líderes dessa rede familiar em expansão eram Daniel de Olanda em Amsterdã e Francisco de Cáceres, no Porto.

\subsubsection{Daniel de Olanda}

Daniel de Olanda pertencia à elite sefardita em Amsterdã, ao lado de nomes como Diogo Dias Querido, Manoel Carvalho, Bento Osório, Manoel Rodrigues Veiga, Duarte Furtado. Diogo Nunes Belmonte, Duarte Saraiva. Seus negócios estavam fortemente envolvidos no comércio do açúcar, seda e diamantes ${ }^{513}$. Na década de 1610 passou a se destacar em uma das atividades mais arriscadas e também uma das que exigiam maiores capitais do investidor, o seguro de cargas e de navios.

${ }^{510}$ Studia Rosenthaliana 1273.

${ }^{511}$ ANTT. Inquisição de Lisboa, Processo 4481-1.

512 Joseph Ben Brith. Dye Odissee der Henrique Familie, op. cit. p.55.

513 Chistopher Ebert. Between Empires: Brazilian sugar in the early Atlantic economy 15501630, op. cit, p. 46. 
O seguro de cargas cresceu como atividade econômica e para Amandio Barros ela já era essencial desde os fins do século $\mathrm{XVI}$, à medida que se tornava mais complexa a burocracia e a papelada para se completar uma viagem transatlântica. ${ }^{514}$ Em 1611, nos cartórios notariais de Amsterdã há registros de mercadores portugueses que faziam seguros regularmente como um dos custos das viagens marítimas. ${ }^{515}$

Durante a Trégua dos 12 anos houve um recrudescimento da pirataria e para Leonor Freire Costa foi nesse momento que cresceu o envolvimento dos comerciantes judeus e cristãos-novos com os seguros marítimos a partir de Amsterdã, como também a prática de um número maior de pessoas dividirem um navio com cargas. Essa operação podia ser tanto pelo arrendamento quanto pela associação efetiva, e os arrendamentos podiam ser feitos por uma única vez. ${ }^{516 .}$ Muitas negociações para o comércio do açúcar ocorriam através de consórcio: dois ou mais agentes se juntavam, por exemplo, para fretarem um navio para o transporte de mercadorias ao Brasil e para o escoamento do açúcar. Assim, eram conseguidas as grandes somas necessárias para as arriscadas empresas marítimas. Apesar disso, "essas redes envolviam a formação de parcerias em que dois ou mais indivíduos se associam para o mesmo fim, seja um contrato de arrendamento, seja a exploração de certas atividades mercantis". 517

514 Amândio Jorge Morais Barros, O negócio atlântico: as redes comerciais portuenses e as novas geografias do trato internacional (séculos XVI-XVII). Revista da Faculdade de Letras. História. Porto, III Série, vol. 8, 2007, p. 29-47.

515 Jessica Vance Roitman, op. cit, p. 54.

516 Leonor Freire Costa. O Transporte no Atlântico e a Companhia geral do Comércio do Brasil (1580-1663) op. cit. p. 220- 229.

517 Christopher Ebert. Between Empires: Brazilian sugar in the early Atlantic economy 15501630, op. cit, 63. 
O negócio dos seguros exigia grandes capitais e também se faziam seguros marítimos em Londres e na Zeelândia. ${ }^{518}$ Além das intempéries naturais, o corso e a pirataria se interpunham como fatores de risco em todas as viagens. Porém, a fraude era um dos maiores problemas a ser enfrentado pelos seguradores. ${ }^{519}$ Um dos casos emblemáticos se deu com o Francisco de Cáceres $^{520}$ que pode ter-se valido da fraude em relação ao carregamento de açúcar trazido do Rio de Janeiro na embarcação De Hoope que obrigou ao seu irmão e filho a darem uma declaração registrada nos cartórios notariais em Amsterdã, jurando que Cáceres, que estava no Porto, em Portugal, desconhecia o roubo da carga feito pelos piratas franceses ${ }^{521}$ È bem provável que esse fato tenha acontecido.

Amsterdã passou a ter maior número de seguradoras pela capacidade de que eles tiveram em confirmar a veracidade das afirmações de seus clientes, em comparação principalmente com os seus concorrentes em Londres, o número de agentes, a intensidade dos fretes e embarques davam aos seguradores maiores informações sobre a possível veracidade dos fatos. ${ }^{522}$ Daniel de Olanda estava nesse ramo de negócio e registrou em cartório notarial em 1615 que anulava o seguro relativo à carga de lã transportada pela embarcação São Miguel Arcanjo de propriedade do comandante Gregorio Del Tippolo de Alicante a Veneza, seguro que deveria pagar 4\% sobre o valor da carga em nome de Jorge Pereira. Afirma ter ouvido que no Estreito de

\footnotetext{
${ }^{518}$ Daniel Strum. The Portuguese Jews and New Christians in the Sugar Trade, op.cit. p. 301.

${ }^{519}$ Leonor Freire Costa. O Transporte no Atlântico e a Companhia geral do Comércio do Brasil (1580-1663) op. cit. p.178.

${ }^{520}$ Studia Rosenthaliana. 328.

${ }^{521}$ Studia Rosenthaliana. 331; 333. 266.

${ }^{522}$ Daniel Strum. The Portuguese Jews and New Christians in the Sugar Trade, op.cit. p. 262-
} 
Gilbratar, a carga foi confiscada e Jorge Pereira estava consciente do fato e não o informou do ocorrido, quando o contrato de seguro foi assinado. ${ }^{523}$

Nesse ano, ele notificou Barent Sweerts, Clas Andrieesz, Jacques van Hanswijck, Jan Jansz, Smith, Hillebrant den Otter, Elias van Geel Wijbraant Warjwijck, que seguraram mercadorias para David de Palestrino. Em 1611 para uma viagem de Sont para Amsterdã, realizada no navio do comandante Cornelis Arentsz e os avisou que o navio tinha afundado e que o total do seguro deveria ser pago a ele, e não a Jacques Niquect. ${ }^{524}$ Quando seu primo Francisco de Cáceres, no Porto, foi preso pela Inquisição, em 1616, ${ }^{525}$ vários de seus acusadores citaram-no como segurador de suas cargas e de viagens, muitas vezes em conjunto com Daniel de Olanda.

Em 1614, notificou o sefardita Manuel de Crasto que comprou suas mercadorias que seriam enviadas da Holanda, passando França, e Daniel Olanda foi o segurador das mesmas. Elas ficariam consignadas com agentes determinados por Daniel de Olanda e se aceitas por Crasto, as letras de câmbio seriam expedidas a favor dos primos de Daniel de Olanda, filhos de sua tia Ana de Milão e Rodrigo de Andrade, moradores em Antuérpia, Jorge e André Rodrigues d'Andrade, declarando que o dinheiro é de Daniel de Olanda. ${ }^{526}$ Em outra ocasião, o grande comerciante também da Nação, Bento Osório, declarou ter vendido 32 caixas de açúcar mascavo para Paulus (Pawels) Buyes. Na transação estavam envolvidos diamantes que Buyes recebeu de Daniel de Olanda, conforme o contrato de fevereiro de 1615, e que

\footnotetext{
${ }^{523}$ Studia Rosenthaliana, 884.

524 Studia Rosenthaliana 756.

${ }^{525}$ Studia Rosenthaliana. 423.

526 Studia Rosenthaliana 644. "Do dia que o dinheiro passou às mãos de pessoas que iam transmiti-lo na forma de uma letra de câmbio ou mandá-lo por navio, De Olanda passou a arcar com todos
} os riscos e passou a segurar a si próprio." 
retornarão para Daniel de Olanda e também seda. ${ }^{527}$ Ao mesmo tempo sua forte ligação com Hamburgo e com o cunhado Álvaro Dinis fica registrada pela letra de câmbio emitida por Dinis e que deveria ser paga por Gomes de Milão. ${ }^{528} \mathrm{O}$ negócio envolveu um holandês e um rico mercador português, Antonio Faleiro, cunhado de Manuel Teixeira ou Manuel Cardoso de Milão. ${ }^{529}$ Em outra ocasião o registro das sete caixas de açúcar branco que foram enviadas da Bahia por Simão Nunes de Matos, onde era senhor de engenho e irmão de seu cunhado Manoel Nunes de Matos, que deveriam seguir para Hamburgo, foram tomadas por piratas durante a viagem. ${ }^{530}$

A rede especializada em diamantes na Europa concentrava-se em Antuérpia, Amsterdã e Veneza. A partir dessas cidades eram redistribuídos para Paris, Hamburgo, Frankfurt, Londres, Nápoles e Madrid. Em Amsterdã os mais importantes correspondentes eram: Bento Osório, Manuel Dias Henrique, Diogo Dias Querido, Diogo Nunes Belmonte, Daniel de Olanda, entre outros. Em Antuérpia se destacavam André Faleiro, Tomé Lopes Ulhoa, Manoel Soares Ribeiro, Jorge Rodrigues d'Andrade, Gil Lopes Pinto, Antonio de Paz, Manoel Soares Ribeiro. Antonio Faleiro, André Rodrigues d'Andrade, Diogo Mendes eram os mais proeminentes mercadores de diamantes em Veneza. ${ }^{531}$

A seda vinda da China era usada pela elite como símbolo de representação social e os diamantes, que pouco estão listados no rol das

\footnotetext{
${ }^{527}$ Studia Rosenthaliana 1032.

${ }^{528}$ Studia Rosenthaliana 482.

${ }^{529}$ Studia Rosenthaliana 487.

530 Studia Rosenthaliana 552.

${ }^{531}$ James C. Boyajian. Portuguese Trade in Asia under the Habsburgs, op. cit, p. 123-126; 131.
} 
mercadorias, eram importante fonte de receita para os mercadores fossem transacionados de forma legal ou ilegal. ${ }^{532}$

\subsubsection{Francisco de Cáceres}

Em 1618, uma forte repressão inquisitorial teve vez no Porto, desmantelando grande parte da comunidade mercantil lá existente. ${ }^{533}$ Um dos presos foi Francisco de Cáceres, que permaneceu encarcerado até 1621.

Francisco de Cáceres, sobrinho de Henrique Dias de Milão vivia no Porto é citado em diversos trabalhos como um dos mais importantes mercadores de seu tempo e expoente do trato transcontinental nas primeiras décadas do século XVII. Homem de grandes posses, ${ }^{534}$ tinha um cartaz afixado na esquina da Rua Nova, uma rua larga onde os comerciantes se reuniam no Porto que divulgavam suas atividades com os seguintes dizeres: Mercador cristão, mediador de seguros. ${ }^{535}$ Ele oferecia esses serviços aos comerciantes locais. Era contratador da alfândega de Vila do Conde, embora malquisto pelos mercadores do Porto. Foi acusado por outros comerciantes e quinhoeiros de ter tomado o contrato da renda dos $3 \%$ de Vila do Conde com outros parceiros, originando com isso perdas de 300.000 reais em cada navio para os contradores da alfândega do Porto. A perda devia-se essencialmente pelo fato de Cáceres fretar os navios para Vila do Conde e não para a cidade do Porto. ${ }^{536} \mathrm{O}$ grau de sua riqueza pode se medido pelos seus bens que foram tomados

532. Christopher Ebert. Between Empires: Brazilian sugar in the early Atlantic economy 15501630, op. cit. p. 78.

${ }_{533}$ Leonor Freire Costa. O Transporte no Atlântico e a Companhia Geral do Comércio, op. cit, p. 186.

${ }^{534}$ Christopher Ebert. Between Empires: Brazilian sugar in the early Atlantic economy 15501630, op. cit. p. 62.

535 ANTT. Inquisição de Lisboa. Processo 3068.
${ }_{536}$ Idem. 
pela Inquisição, no momeno em que foi preso, conforme reproduzimos a seguir; 537

Casas em Santa Comba Dão, bispado de Coimbra com um quintal e que valeriam 50.000 reais;

Dois olivais na mesma vila que valeriam 12 ou 15.000 reais;

Dois olivais pequenos no termo do lugar de S. Miguel, concelho de S. João de Areias e valeriam ambos 12.000 reais;

Na mesma vila de Santa Comba Dão, uma horta à fonte do Casal que parte com Calixto de S. Paio e com o padre António de Andrade e valeria 30.000 reais;

12 alqueires de trigo de foro em cada um ano, onde chamam os Corvelos, termo de Azare que Ihe pagou Jerónimo Antunes;

10 alqueires de trigo no mesmo lugar que Ihe pagou Francisco João;

7 alqueires de trigo que lhe pagou Domingos Martins do Casal, concelho de S. João de Areias;

Mais alqueires de pão que tinha mas que não se lembrava quais eram mas que constava nos seus papéis que tinha em sua casa;

Tinha algumas dívidas para com algumas pessoas e outras lhe deviam a ele mas não se lembrava e remeteu para os seus papéis;

48 peças de baeta de Flandres de um Francisco Mendes Trancoso e que estavam 30 peças em sua casa até ao dia de sua prisão e que está devendo ao dito Francisco Mendes e tem outras coisas que estão descritas nos seus papéis;

Declarou que em poder de Aleixo Ferreira Vila Fanha, escrivão da cidade do Porto está uma escritura onde consta que Manuel Varela, rendeiro da cidade do Porto lhe deve 290.000 reais;

Brás Garcia de Vila de Avo deve-Ihe 400.000 reais que consta dos seus papéis.

Que mandou para o Brasil, para Francisco Gomes Pina 20 pipas de vinho, outras 20 para Pedro Fernandes, 20 para António Rodrigues Chave, 6 pipas que carregou nas ilhas para Tomé Pereira e que havia de passar letras;

${ }^{537}$ Ibidem. 


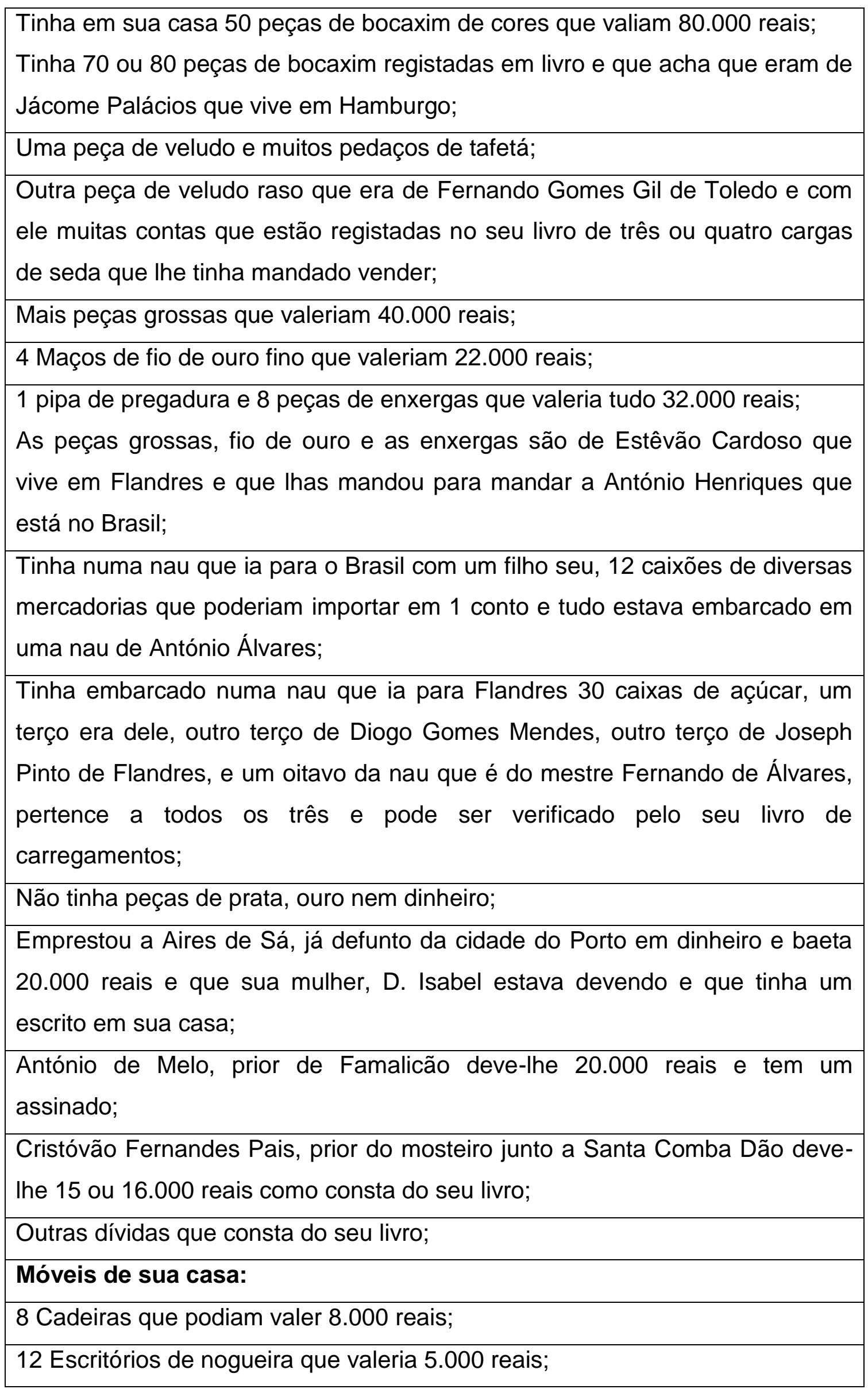




\begin{tabular}{|c|}
\hline \\
\hline 500 \\
\hline ria 2.000 \\
\hline $07 / 11 / 1619$ \\
\hline relos vinha 48.000 reais; \\
\hline de António Carvalho de Vila Nova vinha 45.000 reais; \\
\hline $\begin{array}{l}\text { Tinha carregado } 15 \text { caixas de açúcar em um navio de Baltasar Fernandes de } \\
\text { Massarelos e podiam valer mais de } 200.000 \text { reais forros; }\end{array}$ \\
\hline Emo \\
\hline $\begin{array}{l}\text { Mais } 14 \text { ou } 15 \text { caixas de açúcar que estavam na Alfândega vindas no navio de } \\
\text { Gaspar Rodrigues; }\end{array}$ \\
\hline $\begin{array}{l}\text { Manuel Francisco, ferreiro e morador no Porto, à porta do Olival devia-Ihe por } \\
\text { sentença } 70.200 \text { reais, sentença que tinha André Pinto, escrivão do } \\
\text { corregedor do cível; }\end{array}$ \\
\hline $\begin{array}{l}\text { Simão Silvestre, cordoeiro, morador no Porto, à porta do Olival devia-lhe } \\
15.000 \text { reais por sentença que ele tinha em seu poder ou estava em poder de } \\
\text { um requerente mancebo, que não sabe o nome; }\end{array}$ \\
\hline $\begin{array}{l}\text { António Pires, sombreireiro, morador no Porto na Rua dos Mercadores ao } \\
\text { Colégio Velho da Ponte, devia-Ihe } 30.000 \text { reais, estando penhoradas umas } \\
\text { casas e o escrivão da penhora era Gabriel Fernandes Soares; }\end{array}$ \\
\hline $\begin{array}{l}\text { Manuel Valeta, maceiro, de alcunha, o Barca, morador ao pé das Caldas } \\
\text { devia-Ihe } 7 \text { ou } 8.000 \text { reais, de um porco que lhe tinha vendido sem assinado; }\end{array}$ \\
\hline $\begin{array}{l}\text { Francisco Rodrigues Vila Real, médico, devia-lhe } 20.000 \text { reais em dinheiro e } \\
\text { uma peça de chamalote roxo e que valeria } 4.500 \text { reais e devia existir algum } \\
\text { escrito; }\end{array}$ \\
\hline $\begin{array}{l}\text { Manuel Rodrigues Vila Real, morador na Rua de S. Miguel, vestimenteiro } \\
\text { devia-lhe } 70 \text { mil e tantos reais de sedas de cartela que Ihe tinha fiado como } \\
\text { consta nos livros de ambos; }\end{array}$ \\
\hline $\begin{array}{l}\text { Álvaro de Azevedo devia-lhe } 80.000 \text { reais de um seguro que lhe fez de um } \\
\text { navio que se perdeu na barra com melaços; }\end{array}$ \\
\hline $\begin{array}{l}\text { Tinha fiado a Gaspar Fernandes Trancoso de Santa Comba Dão } 200.000 \\
\text { reais e tinha uma sentença contra o fisco sobre a fazenda de Gaspar }\end{array}$ \\
\hline
\end{tabular}


Fernandes. Se ele não recebesse o dinheiro de Gaspar Fernandes Trancoso, o fisco devia fazer o pagamento pelo devedor;

João Rodrigues Vila Real, rendeiro, natural do Porto, ausente em Pernambuco há 4 anos, devia-Ihe perto de 300.000 reais de mercadorias que Ihe tinha fiado e que deve existir um assinado, mas a conta certa está registada no livro;

Fiou 100.000 reais a João Rodrigues que devia a Pedro Baram, francês, morador na cidade do Porto, da venda de uma loja. João Rodrigues através de uma escritura ficou obrigado aos 100.000 reais e Luís Preto, sogro de João Rodrigues passou um assinado;

Ao tempo da sua prisão tinha dado uma peça de baeta de 100 fios, preta e de 54 côvados para frisar a um tosador mancebo que não sabe o nome e vive por cima de António Fernandes Palha, mercador;

António Fernandes, alfaiate, morador na ponte de S. Domingos devia-Ihe 180 ou 20.000 reais de baetas e havia um assinado;

Outro António Fernandes, morador ao fundo da Rua dos Mercadores, entrando na Praça da Ribeira devia-Ihe 90 ou 100.000 reais de baeta e de outras coisas que lhe emprestara para fazer vestidos, por ser alfaiate. E tinha prometido ao réu 2 caixas de açúcar, uma de branco e outra de mascavado que estavam já no rio, no navio de Tomé António;

Marcos Garcia morador na vila de Avo devia-Ihe 1000 cruzados ou mais de baetas e linho que veio de Flandres e tinha assinados de Brás Garcia, filho do sobredito devedor e carta do devedor;

Ao tempo da sua prisão tinha para lançar em livro um carregamento que veio de Toledo há dias e esteve embarcado em Valverde por causa de uns mantos que vinham embrulhados em umas raxetas de importância de 3.000 cruzados e vinha por conta de Fernando Gomes Gil de Toledo;

Ao tempo da sua prisão, havia em sua casa 18 barris de aço que valiam 1.000 reais cada um;

Disse que não se lembrava de mais nada, mas que em sua casa achariam tudo o que tinha. 
Trabalhava com uma gama de produtos coloniais e se destacava nos negócios do açúcar. Tinha como correspondentes na Bahia Simão Nunes de Matos, ${ }^{538}$ senhor de engenho e Francisco Gomes Pina, Pedro Fernandes e Tomé Pereira, além de Pero de Palácios, em Hamburgo. No Brasil, em Pernambuco e na Bahia, contava com oito correspondentes ${ }^{539}$ e estava presente em negócios de grande monta com açúcar em Amsterdã, onde tinha como correspondente seu irmão José Pinto e seu primo Gomes Rodrigues de Milão (Daniel de Olanda). Seus filhos também já estavam inseridos no trato em Amsterdã e Rouen. Sua participação no trato do açúcar pode ser medida pelo levantamento da relação de bens que consta do seu processo da Inquisição de Lisboa. ${ }^{540}$ Assim que foi preso, consta que era proprietário de dez caixas de açúcar. "Tinha embarcado numa nau que ia para Flandres 30 caixas de açúcar, um terço era dele, outro terço de Diogo Gomes Mendes, outro terço de Joseph Pinto de Flandres (seu irmão) e um oitavo da nau que é do mestre Fernando de Álvares, pertence a todos os três e pode ser verificado pelo seu livro carregamentos. ${ }^{541}$ "Tinha carregado 15 caixas de açúcar em um navio de Baltasar Fernandes de Massarelos e podiam valer mais de 200.000 reais forros; em outro navio mais 5 caixas de açúcar que valiam 60.000 reais; mais 14 ou 15 caixas de açúcar que estavam na Alfândega vindas no navio de Gaspar Rodrigues"; Simão Nunes de Matos tinha carregado 40 caixas de açúcar e metade era dele e metade Joseph Pinto de Flandres (seu filho) seus bens e ativos eram de grande monta. Se considerarmos que com apenas

\footnotetext{
538 ANTT. Inquisição de Lisboa. Processo 12067.

${ }^{539}$ Daniel Strum. The Portuguese Jews and New Christians in the Sugar Trade, op. cit, p, 288.

${ }^{540}$ ANTT. Inquisição de Lisboa. Processo 12067.

${ }^{541}$ Idem.
} 
panos vindos de Toledo ele tinha três mil cruzados, um valor altíssimo para uma transação. "Ao tempo da sua prisão tinha para lançar em livro um carregamento que veio de Toledo há dias e esteve embarcado em Valverde por causa de uns mantos que vinham embrulhados em umas raxetas de importância de 3.000 cruzados e vinha por conta de Fernando Gomes Gil de Toledo. ${ }^{542}$ Foi obrigado a usar o hábito penitencial, mas conseguiu sua suspensção em $1623 .{ }^{543}$ Em seguida retomou sua liderança na rede dos Milão, mantendo-se extremamente ativo no trato do açúcar, deslocando-se diversas vezes a Amsterdã. ${ }^{544}$

Daniel Strum ${ }^{545}$ resgatou uma rara correspondência entre Francisco de Cáceres a seu agente em Hamburgo, Pero de Palácios, composta por quatro cartas, a quem Strum reconhece ser um judeu em Hamburgo, mas não teria como identificar a relação de proximidade parental entre Cáceres e Palácios, sendo o elo entre eles Álvaro Dinis, Manuel Teixeira e Pero ser casado com Isabel, a caçula do casal Henrique e Guiomar Milão.

Essas missivas são importantes porque por meio delas temos detalhes das transações entre os mercadores. Na primeira carta, datada de 24 de novembro de 1617, pergunta sobre a saúde de Jacome de Palacios (irmão de Pero Palácios) e informa sobre 110 peças de entretelas que ele tinha recebido e ele esperava que fosse de boa qualidade para que ele pudesse fazer algum lucro com isso. De qualquer forma, ele prometeu fazer o seu melhor esforço para obter a melhor vantagem com eles. Escreveu que ele ainda não havia

\footnotetext{
542 Ibidem.

${ }^{542}$ Idem, Ibidem.

${ }^{543}$ ANTT. Inquisição de Lisboa. Processo 3068.

${ }^{544}$ Studia Rosenthaliana 936.

${ }^{545}$ Daniel Strum. The Portuguese Jews and New Christians in the Sugar Trade, op. cit. p. 62-
} 266; p 278-296. 
conseguido vender seis feixes de ouro deixa que ele também recebido de Jacome de Palacios. No entanto, no dia anterior, ele tinha vendido para Manuel Rodrigues Vilareal, outro mercador cristão-novo do Porto, sem estipular qualquer preço para ele, provavelmente uma venda consignada São mencionadas a espera do envio de letras de câmbio por seu filho José Pinto de Amsterdã (seu filho) e que esperaria as ordens de Jácome Palácios sobre essa transação financeira e, ao mesmo tempo, Jacome instruíria Francisco sobre onde investir o dinheiro após o recebimento.

Nas demais correspondências, vultosos negócios relativos ao açúcar ficam patentes. Ele prometeu carregar açúcar para seus associados nos navios que zarpariam para Hamburgo, e já tinha ordenado que isso fosse feito. Ele iria comprá-lo no local pelo preço atual. Jacome havia ordenado adquirir a mercadoria até a soma total de 1.100 cruzados, o que era um grande montante. Também a parceria com Jácome Palácios se repete na compra de centeio em Amsterdã, com outros judeus portugueses.

A preocupação com o Santo Ofício e o confisco de bens era um dos maiores temores dos cristãos-novos, como já vimos ao longo deste trabalho. Nas missivas entre Francisco e Pero de Palácios, há o registro das ações tomadas por Cáceres relativas à prisão pela Inquisição de Manuel Francisco Vilareal, mercador cristão-novo com quem tinha fortes ligações comerciais, e seu sobrinho. Ele pediu a libertação de todos os bens penhorados, incluindo a parcela de ouro pertencente ao Jacome Palacios.

Além disso, escreveu que ele não recebeu nenhuma letra de câmbio de José Pinto, ainda, mas uma vez que ele recebeu iria seguir as ordens Jacome de Palacios. O universo de mercadores com os quais mantinha negócios é 
considerável e estão registrados nos cartórios de Viana, do Porto e mais fartamente em Amsterdã. ${ }^{546}$

De Cáceres, como muitos outros comerciantes da época, financiava e emprestava dinheiro para terceiros em Portugal e no Brasil, inclusive para a produção da safra de açúcar. Obviamente as acusações que constam no seu processo do Santo Ofício não podem ser tidas como fidegninas, mas pelas declarações do réu sobre seus bens, nos indicam que ele dispunha dinheiro para os que estavam na atividade açucareira.

\subsubsection{As relações com os da Nação}

Analisando a documentação levantada com os quais Francisco mantinha relações comerciais, identificamos que a maior parte são cristãos-novos e muitos aparentados. ${ }^{547}$ Chama-nos a atenção o fato dos holandeses serem os capitães dos navios, portanto, ligados ao transporte.

Em Hamburgo, de 1617 a 1619, todos os seus correspondentes eram cristãos-novos: Jacome de Palacios; Álvaro Dinis; Gabriel Valença (filho de Gonçalo Valença); comandantes de navios: Pero de Palacios; Tonis Meimer, Dirck; Alders Dirck Martensz eram flamengos.

\footnotetext{
${ }^{546}$ Studia Rosenthaliana 934.
}

547 O levantamento dos nomes dos correspondentes, carregadores, caixeiros, agentes, local e ano foi feito por Daniel Strum em sua tese de doutoramento The Portuguese Jews and New Christians in the Sugar Trade: Managing Business Overseas Kinship and Ethnicity Revisited,op.cit. Appendix IV.Florbela Veiga Frade. O Trato e a Família, op.cit. Appendix 4A. James C. Boyajian. Portuguese Bankers at The Court of Spain, op.cit. Appendixes A-1 a A-18. José Antonio Gonsalves de Melo. Gente da Nação, op.cit. Dicionário Histórico dos Sefarditas Portugueses (Homens de Cultura e de Ciência). Lisboa: Cátedra de Estudos Sefarditas Alberto Benveniste, 2010. ANTT. Inquisição de Coimbra, processos: 7703, 9377; ANTT. Inquisição de Lisboa. Processos: 3068; 13016, 6677;12493, processo de Heitor Mendes Bravo que voltou a Lisboa e se entregou aos Santo Ofício, Em 1617, confessou que vinha da Holanda, partes de Flandres a Lisboa, somente para acusar suas culpas e pedir misericórdia, pois está muito arrependido de as ter cometido, dando sinais de arrependimento, pois foi circundado em Amsterdã. Em suas culpas, entregou todos os judeus (mulheres e filhos) que viviam em Amsterdã e Hamburgo com os quais tinha tido contato ou sabia que seguiam a Lei de Moisés. Esse processo é precioso para o cruzamento de informações sobre a origem dos cristãos-novos aos quais nos referimos. 
Em Pernambuco entre 1615 e 1618 entre seus correspondentes eram cristãos-novos: Francisco Gomes Pina, Francisco Fernandes, Rodrigo Alvares Drago, Antonio Henriques Alvim. Era seu credor João Rodrigues Vilareal, também cristão-novo. Pardego Massarelos comandante de um navio

$\mathrm{Na}$ Bahia em 1618 relacionados ao açúcar e Francisco estavam os cristãos-novos Denis Bravo, Francisco Mendes Cardoso, Simão Nunes de Matos, Manuel Tome. Não conseguimos identificar Manuel de Campos Porto se era ou não cristão-novo.

Em Amsterdã, entre 1613 e 1618 relacionados aos seus negócios tivemos os cristãos-novos: Gomes Rodrigues Milão (primo); José Pinto (irmão); Francisco Gomes Henriques; Antonio Mendes Cardoso; Antonio Mendes Trancoso; Francisco Mendes Trancoso; Duarte de Palacios; Estevão Cardoso; Antonio Henriques; Daniel Pinto; Francisco Lopes de Frandes; Manuel de Oliveira de Paz; Simão Rodrigues de Caceres (filho); Jeronimo Henriques. Comandantes de embarcações flamengos: Claes Gerritsen "Vos" Enkhuizen; Cornelis Claesz; Dirck Cornelisz.

\subsection{A associação com os não sefarditas}

Olanda e diversos outros sefarditas entre eles Manuel Rodrigues Vega; Manoel Carvalho; Duarte Fernandes; Francisco Nunes Homem; Simão de Mercado; Diogo Nunes Belmonte; Belchior Mendes; Garcia Gomes Vitoria; Juan Goncales; David de Palestrino, Diogo Dias Querido, Bento Osório mantiveram negócios com os não judeus em contratos registrados nos arquivos notariais de Amsterdã. 
Havia estrangeiros vivendo em Portugal e no Brasil envolvidos no trato colonial ao menos desde o início do século $\mathrm{XVI}^{548}$. Os registros da Primeira Visitação do Santo Ofício ao Brasil (1591-1595), informam que na empresa açucareira, em Pernambuco, viviam os flamengos Manuel Nunes, André Pedra, Alberto Rodrigues e Antônio Vilhete e o padre João Batista e Maria de Almeida, esta "mulher do mundo" moradora em Olinda. Residiam ou negociavam em Olinda outros flamengos de nome Guilherme Fraute "valonês", Jande Betta; Miclas Silvestre, Estevão Snewatter, Paulo Cibres, Martim Alonso, e Baltazar Vularte Ratz, "este flamengo natural de Amberres" lavrador em Jaboatão. Um deles foi senhor do engenho, Gaspar de Mere, associado ao rico mercador de Antuérpia, Jerônimo Goossens. ${ }^{549}$

Alguns flamengos se destacaram na associação com a Gente da Nação. Entre eles estavam os Cornelius Snellinck, nascido em Antuérpia, numa família tradicional de mercadores que foi para Amsterdã em 1598. Foi casado com Leonora da Veja que provavelmente tenha sido descendente do ramo da família Rodrigues Veiga, uma das mais importantes na mercancia radicada na cidade do Escalda. Os registros notariais o colocam como associado aos grandes mercadores sefarditas e profundamente envolvido no comércio do Brasil. Sua participação era tal que passou uma procuração para que pudesse ser resolvida uma disputa que mantinha com João Nunes Correia, então asientista de escravos, sobre um carregamento de pau-brasil. Em 1606 tinha muitos correspondentes em Lisboa. Daniel de Olanda associou-se a ele em mais de uma vez e teve negócios de grande vulto por muitos anos com Manoel

${ }^{548}$ Vide capítulo 1.

${ }^{549}$ José Antônio Gonsalves de Mello. O Recife: importância do período nórdico-tropical de sua formação. Seminário de Tropicologia: trópico \& o Recife eurotropical. Anais..., 1977. Recife. Fundaj; Massangana, 1987, p. 188-198. 
Rodrigues Veiga. Em 1604, foi sócio desse comerciante de grosso trato em uma viagem a Angola. ${ }^{550}$

Outro associado foi o flamengo Albert Schuyt que tinha tido sua vida comercial em Antuérpia e chegou em Amsterdã em 1603. Era casado em segundas núpcias com uma parenta dos Nicquet, ligados ao comércio italiano e ao Levante. Dedicou-se aos seguros e ficou conhecido como segurador dos sefarditas. A principal associação entre Schuyt e Olanda era no transporte do açúcar. Há registros que mostram o transporte de açúcar entre Viana e Amsterdã e Amsterdã e Hamburgo. Em outra ocasião, Olanda era partícipe da carga de um navio do Brasil para o Porto.

\subsubsection{A associação com os holandeses}

Ao analisarmos a associação entre os holandeses e os da Nação em Amsterdã, percebemos que grande parte dos negócios, está ligada ao transporte de mercadorias, visto que os holandeses eram proprietários de navios ou com ligações com o trato de grãos, de armas. Um levantamento feito com os contratos realizados entre sefarditas e "flamengos" que mencionam Danzig (Gdansk), ${ }^{551}$ tendo como base 67 registros notariais de Amsterdã compilados na Studia Rosenthaliana que mencionam Danzig, nos mostram que 58 deles dizem respeito ao fretamento de embarcações pelos da Nação com os capitães delas.

${ }^{550}$ Christopher Ebert. Between Brazilian Sugar op. cit. p. 80-81.

${ }^{551}$ Registros notariais da Comunidade Judaica Portuguesa de Amsterdã que atestam a atividade de comerciantes sefarditas em Dantzig, nos séculos 16 e 17. Registros notariais relativas aos judeus Português em Amsterdã até 1639 Studia Rosenthaliana. Levantamento realizado por Tielen Ton para <http: //www.jewishgen.org/danzig/>. Acesso em: 22 fev. 2014. 
Contrato de afretamento entre Manuel Lopes Homem e capitão Joost Jansz de Danzig. Contrato de afretamento entre Manuel Lopes Homem (Homme), comerciante da nação Português residente em Amsterdã, e Jansz Joost de Danzig, capitão do navio "Roode Leeuw (Red Lion), capacidade de 60 toneladas. O capitão deve levar uma carga completa de grãos de Amsterdã para Vila do Conde. O piloto tem que ser tomado em consideração para entrar neste porto. Caso isso seja impossível, o capitão deve consultar os outros e, se necessário, para navegar em Viana. O grão é para ser entregue à pessoa designada pelo comerciante. Se a carga for descarregada em Vila do Conde, a sobrecarga do comerciante deve informar o condutor no prazo de 14 dias, se $o$ comerciante deseja manter o navio a seu serviço. Se assim for, o capitão é obrigado a permanecer ancorado em Portugal por 35 dias e, em seguida, a navegar de volta para Amsterdã. A taxa de frete é ser 6 1/2 duc., por último de centeio entregue em Vila do Conde e 37 gld., por último de centeio embarcado em Amsterdã, se o capitão voltar com a carga de retorno.

Studia Rosenthaliana 157 (1.604, 20 de outubro, NA Arch. 99, fol. 5v.-7, NA. Janeiro Fransz. Bruyningh.)

Contrato de afretamento entre Francisco de Pas, comerciante em Amsterdam ação para Gabriel Lopes, comerciante em Hamburgo, e capitão Pieter Outgersz. de Warder, para uma viagem com o navio St. Pieter, 50 grandes dura de centeio, de Amsterdã via Danzig, onde o (navio) será carregado a Viana ou Porto, a uma carga de 5 1/2 cruzados em 10 reais a um crusado passado. Após a entrega do capitão receberá um bônus de 3 cruzados. Se em Dantzig madeira ou outros bens que não podem ser medidos por último são carregados, o capitão será pago por 50 dura menos 5 cruzados e meio. 
Studia Rosenthaliana 2.059 (1,62 mil, 26 de março NA Arch 625, p 481-483;..... Sibrant Cornelisz)

Também temos como exemplo com Manoel Carvalho outro grande mercador em Amsterdã, muito ligado ao comércio Atlântico, que comprou uma parte de um navio com os flamengos. Em 1610, Carvalho foi o último elo de uma letra de câmbio para a compra e participação em um navio. Esta letra de câmbio foi emitida por Joost Benninck em Lisboa, que passou para Jaspar Moermans em Roterdã, fazendo,, em seguida, o endosso para Jan van Dashorts em Amsterdã, que repassou-a para Carvalho.

Manuel Rodrigues Vega era da proeminente da família Rodrigues da Veiga de Antuérpia, aparentada com os Ximenes. Ainda menino foi mandado para Nantes onde se iniciou no trato e chegou a Amsterdã aos 20 anos. Valendo-se da rede de comércio familiar à qual estava inserido envolvida no comércio colonial. Em pouco tempo Rodrigues Vega destacou-se no comércio de grãos do Báltico, no trato do pau-brasil, no tráfico negreiro. Vega também valeu-se dos contatos da rede à qual pertencia para poder se projetar em Amsterdã e ser considerado um dos mais ricos e bem-sucedidos.

Ele associou-se a não sefarditas como Laurens Joosten Baeck, um comerciante proeminente do Holanda do Sul que estava envolvido no comércio de açúcar, bem como vários outros negócios. Estavam em parceria para o carregamento de 60 fardos de gengibre em 1612. Eles também tinham tido conexões comerciais no negócio das Índias Orientais, em 1601, quando Vega e Baeck trataram um carregamento de pimenta que Baeck trouxe, em 1605, em 
um navio capturado dos espanhois, obtendo lucro de mais de $160 \%$ sobre o capital investido. Baeck recebeu cerca de 550 ducados flamengos. ${ }^{552}$

\subsection{O comércio entre os da Nação}

Os dois mais bem-sucedidos e com imensas fortunas em Amsterdã eram Manuel Rodrigues Vega ${ }^{553}$ e Duarte Fernandes. ${ }^{554}$ Outros grandes mercadores lá fixados, que constam dos arquivos notariais de Amsterdã reproduzidos na Studia Rosenthaliana entre 1606 e 1624, nos mostram muitos dos membros das famílias de destacados senhores de engenho e comerciantes ligados ao açúcar que estiveram em Pernambuco ${ }^{555}$.

A análise dos registros notariais de Amsterdã mostra que as transações relativas ao açúcar se deram predominantemente entre os cristãos-novos (judeus) dos principais centros produtores - Pernambuco e Bahia - como também Antuérpia, Porto e Lisboa. Os registros dizem respeito principalmente às letras de câmbio, ${ }^{556}$ perdas de cargas, mudanças nos contratos, danos, pirataria, embarques, desavenças entre os envolvidos na transação, seguros e 273.

\section{$552 / 1387$.}

${ }^{553}$ Jessica Vance Roitman. The Same but Different? op. cit. p. 40; O trato e a família, op. cit. p.

${ }^{554}$ Florbela Veiga Frade. O trato e a família, op.cit. p. 293.

555 Entre os carregadores reconhecidos como cristãos-novos estavam Ambrósio Fernandes Brandão, André Gomes Pina, Antônio Dias do Porto, Antônio Mendes, Bento Álvares , Diogo Soares, Duarte Dias de Flandres, Duarte Dias Henriques, Duarte de Sá, Duarte Ximenes, Fernão Soares, Filipe Diniz do Porto, Francisco Dias Soares, Francisco Lopes Homem, Francisco Rodrigues do Porto, Gaspar Fernandes Anjo, Gaspar Ximenes, Gomes Rodrigues Milão, Henrique Rodrigues, João Nunes de Matos, João Ribeiro, João Soeiro, Jorge Fernandes, Jorge Ferreira, Jorge Tomás, Luís Antunes, Manuel Carvalho, Manuel Nunes Lopes, Manuel Nunes, Manuel Nunes de Matos, Manuel Rodrigues do Porto, Manuel Vaz Pimentel, Miguel Dias de Santiago, Paulo de Pina, Pedro Henrique, Pedro Lopes, Pedro Lopes de Vera, Simão Vaz e Tomás Fernandes., José Antônio Gonsalves de Mello. "Os Livros das Saídas das Urcas do Porto do Recife, 1595-1605”. Revista do Instituto Arqueológico, Histórico e Geográfico Pernambucano. Recife, 1993, p. 21-145.

${ }^{556}$ A letra de câmbio desenvolve-se em dois momentos distintos: no primeiro, o dador entrega o dinheiro ao tomador e indica-lhe qual o beneficiário desse dinheiro que está situado numa praça distinta. Outo tomador produz um documento no qual cabe ao pagador um determinado valor em determinado moeda que será pago ao beneficiário. 
carregamentos. Cerca de sessenta e oito por cento das ações com açúcar que não envolvem transporte se davam entre os sefarditas.

Os grandes comerciantes eram: Manuel Rodrigo da Veiga, Manuel Carvalho, Bento Osório, Diogo Dias Dias Querido, Diogo Dias Belmonte (filho de Diogo Dias Querido), Jerônimo Henriques, Estevão Cardoso, Francisco de Cáceres, Paulo de Pina, Duarte Dias Henriques, Daniel de Olanda. 


\section{Considerações finais}

A Expansão Ultramarina ibérica reconfigurou a dinâmica econômica europeia, deslocando as especiarias para Portugal, que com a descoberta da Rota do Cabo, colocava o Mediterrâneo em segundo plano. Até então, Gênova, Veneza, Florença e o ducado de Milão, sobretudo genoveses, dominavam as águas do Mediterrâneo e o comércio com o Oriente, abastecendo a Europa com as especiarias, em especial a pimenta, seda, veludo, marfim, vindas das Índias. O domínio italiano no Mediterrâneo impedia a passagem e o acesso de outros povos europeus ao rico comércio com o Oriente.

Os altos lucros auferidos pelos mercadores italianos levaram a Coroa portuguesa procurar uma rota alternativa marítima para as Índias, que

permitisse participar desse rentável trato. Contornando a África, em 1498, Vasco da Gama chegou a Calicute, descobrindo a Rota do Cabo. Essa via marítima, entre 1500 e 1530, o comércio feito entre Lisboa e as índias suplantou a Rota do Levante que estava nas mãos dos italianos e árabes. Os portugueses obtiveram êxito no bloqueio da passagem pelo Mar Vermelho, e tomaram para si o fornecimento de grande parte do trato das especiarias orientais, atraindo, assim, o interesse dos grandes financistas e mercadores alemães e italianos do período. A partir de 1506, os navios carregados com milhares de quintais de pimenta eram obrigados a ser descarregados em Lisboa, na Casa das Índias, de onde eram reexportadas para toda a Europa.

Sob os auspícios da Coroa, as armadas seguiram para o Oriente, e a pimenta e as especiarias das Índias alcançavam em Lisboa altas margens de lucros. Combalida em suas finanças, diante de gastos com a manutenção da 
corte, com a contratação das armadas e as despesas com o Estado da Índia, a Monarquia apoiou-se em banqueiros alemães e italianos, e gradativamente substituiu-os por banqueiros e financistas portugueses cristãos-novos.

A reexportação das especiarias orientais que chegavam ao Reino para outras praças europeias garantiu grandes lucros aos mercadores que detinham esses fluxos de revenda. Antuérpia era o mais importante polo de distribuição das mercadorias no continente, o grande empório europeu. Para lá afluíam tanto as mercadorias trazidas via Portugal como, também, as manufaturas das áreas próximas ao Mar do Norte e Báltico.

Era permitido que os mercadores trouxessem do Oriente, mercadorias, que não a pimenta, o que Ihes permitia auferir grandes lucros. Os cristãosnovos organizaram-se em redes de comércio formadas por companhias familiares, de empresas cujo núcleo inicial era constituído por uma família de mercadores e sua parentela. Famílias que se organizavam em termos como verdadeiras companhias, com estrutura de negócio seguindo a lógica da dinâmica familiar, sob a liderança do patriarca, na qual os papeis dos filhos e genros se definiam em termos econômicos nessa mesma dinâmica familiar, estes como agentes, representantes, correspondentes, e os que foram se alargando em função de estratégias - matrimoniais, sobretudo que proporcionam alianças valiosas e que garantiam a manutenção e ampliação de seu poderio. Essas famílias cristãs-novas portuguesas, como os Duarte Ximenes, os D'Andrade, os Milão, os Veiga, os Solis, os Paz, os Tinoco, os Teixeira/Sampaio/ os Nunes Correia, entre outros compunham a elite dos negócios e os mercadores mais ricos do Reino. Esse seleto grupo chegou a representar grande parte de todo o comercio do Oriente e esteve sempre à 
sombra da Coroa, arrematando os mais lucrativos contratos, e socorrendo-a financeiramente, ocupando espaços econômicos abertos ou determinados por ela, muitas vezes em um jogo complexo de fluxo e refluxo.

No fim do século XVI, frente às dificuldades de a Coroa manter o comércio da pimenta, o contrato de exploração foi arrematado pelos Ximenes d'Aragão, o mais poderoso clã cristão-novo de sua época, que se associou a outras famílias cristãs-novas com grandes cabedais como os Gomes d'Elvas, os Rodrigues d'Evora e Veiga, os Rodrigues e os Solis.

Henrique Dias de Milão, irmãos, cunhados e sogro deslocaram-se para o Oriente, participando ativamente do comércio oriental, investindo na Rota do Cabo onde fizeram fortuna, embora descendessem de famílias abastadas ligadas ao trato. Somente Henrique, seu irmão Antonio Dias de Cáceres e um cunhado não perderam a vida nas Índias.

Grandes clãs mercantis cristãos-novos enriquecidos no trato asiático e na reexportação destacavam-se na nova dinâmica europeia e passaram a controlar tanto as finanças quanto esses fluxos de revenda. Membros dessas famílias estabeleceram-se em Antuérpia, migrando com parte de seus capitais, enquanto outros permaneciam em Lisboa. A difusão geográfica do trato intra e extra continente provocou a migração de outros integrantes dessas famílias de grosso trato para as praças estratégicas no comércio transcontinental. A profusão incessante de novos negócios levou milhares de pessoas ligadas ao trato europeu para a Ásia, África e América. Formavam-se redes de comércio que dinamizaram o comércio mundial interconectadas aos banqueiros e financistas. 
Nesse crescer econômico, as redes em período de "consolidação" no trato internacional se limitaram ao grupo étnico como forma de evitar o seu alargamento e evitar a evasão ou diminuição dos capitais. Ao contrário, por meio dos casamentos endogâmicos, uniam-se famílias e interesses econômicos e fortunas.

A expansão Atlântica e o desenvolvimento da empresa açucareira na colônia brasileira marcaram uma mudança significativa na economia portuguesa e europeia. A empresa açucareira no Nordeste do Brasil tornou-se um dos pilares da economia lusa a partir da segunda metade do século XVI. Nesse novo cenário, as redes efetivamente passaram a consolidar suas fortunas para alcançar o patamar global, atuando em todos os níveis do trato colonial.

Grandes clãs mercantis cristãos-novos enriquecidos no trato asiático e na reexportação destacavam-se na nova dinâmica europeia e passaram a controlar tanto as finanças quanto esses fluxos de revenda. Membros dessas famílias estabeleceram-se em Antuérpia, migrando com parte de seus capitais, enquanto outros permaneciam em Lisboa. A difusão geográfica do trato intra e extra continente provocou a migração de outros integrantes dessas famílias de grosso trato para as praças estratégicas no comércio transcontinental. A profusão incessante de novos negócios levou milhares de pessoas ligadas ao trato europeu para a Ásia, África e América. Formavam-se redes de comércio que dinamizaram o comércio mundial interconectadas aos banqueiros e financistas.

A empresa açucareira no Nordeste e a consequente expansão Atlântica trouxe mudança significativa para a economia portuguesa e europeia. A 
atividade do açúcar, desde o início, contou com capitais dessas redes de comércio sefarditas, não só no financiamento, mas em investimentos diretos na produção. Homens de projeção dessas redes formadas por famílias cristãsnovas estabeleceram-se no Nordeste açucareiro como senhores de engenho, fornecedores de crédito aos que aqui residiam para construção de engenhos, financiamento da safra, e mercadores que enviavam ao Reino a produção sacarina e importavam os bens a serem consumidos na colônia. Suas atividades eram múltiplas na colônia, e seus negócios não se limitavam à empresa açucareira. Os mais destacados dos cristãos-novos tinham ligações com o tráfico negreiro, com o estanco do pau-brasil, com o recebimento dos contratos de dízimos, com interesses na Ásia, nas regiões mineradoras da América Espanhola.

Importantes membros dessas redes tornaram-se senhores de engenho ou colocaram familiares como correspondentes e agentes estabelecidos em Olinda e na Bahia. Os meninos dessas famílias vinham para a casa de parentes para serem treinados no trato.

Sem dúvida, a Inquisição portuguesa teve uma grande influência no comportamento das redes de comércio, visto que sua ação repressiva previa o confisco de bens, a prisão, tormentos, o que atemorizava os conversos, fossem eles judaizantes ou não. A Coroa também usou como moeda de troca os Perdões Gerais para livrar os cristãos-novos dos cárceres da Inquisição quando necessitava do dinheiro da Gente da Nação para cobrir os grandes déficits do tesouro real.

Os Milão não chegaram a Amsterdã com a riqueza que tinham em Portugal, porque seus bens foram confiscados, mas se tornaram expoentes do 
trato transcontinental. O que Ihes valeu foram os contatos prévios, a sua rede de comércio anterior. Embora os negócios estivessem em expansão em termos geográficos, com a incorporação de novas áreas como o extremo Norte da Europa e a África Ocidental, o que significava a necessidade de expansão das redes, nossa pesquisa nos mostrou que os grandes e mais importantes comerciantes continuaram com o trato muito fechado entre as mesmas famílias aparentadas, embora distribuídas por mais praças de comércio pela Europa e América. Houve sim, a incorporação de não sefarditas a essas redes, em especial holandeses, mas pelo que pudemos constatar, muitos ligados ao transporte das mercadorias.

No final do período o qual estudamos, Londres já despontava como importante centro de comércio e mesmo não sendo permitido 0 estabelecimento de judeus na Inglaterra, membros das redes cristãs-novas lá viviam.

O estudo da família Dias de Milão, além de ilustrar a trajetória dos cabedais investidos nos negócios coloniais e difundidos nas praças europeias, aclara importantes aspectos da dinâmica das redes mercantis, sua estruturação e relação com as Coroas lbéricas. 


\section{Fontes e Bibliografia}

\section{Arquivo Distrital do Porto:}

- Procuração [1596] passada por causa de uma contenda que traz a listagem dos negociantes. Distribuição do açúcar no Navio S. João [1578]. Gaspar de Pina, Simão Vaz, Henrique Dias (estes cristãosnovos).

ADP - Cabido, liv. 108, fls. 51-53

- Procuração [1600] passada por Isabel de Oliveira, viúva de Manuel Gonçalves, piloto, patrão da ribeira de Pernambuco, a António Dias Rendufe, para receber de Luís Mendes, mercador e morador na cidade do Porto, 35000 reais de uma letra que tem aceite e que sobre ela passou Manuel Nunes de Matos, estante em Olinda, capitania de Pernambuco.

ADP Notarial, Vila do Conde $1^{\circ}$ cart. 1 sr lv 22 fl. 63.

- Procuração [1600] passada por Isabel Rodrigues, viúva de Marcos Álvares, piloto, a João Vicente Carneiro, mercador, morador em Vila do Conde, ora residente em Lisboa, para receber a quantia que the era devida do seguro que se fez sobre a nau Santo António, pertencente ao marido, e que partira de Lisboa rumo à ilha de São Tomé. Foram seguradores Diogo Lopo, Francisco Lopes, Duarte Fernandes, Francisco Rodrigues, Jorge Fernandes, mercadores e moradores na cidade de Lisboa.

ADP Not V Conde 1 cart 1 sr lv $22 \mathrm{fl} 9 \mathrm{v}-10 \mathrm{v}$

- Procuração passada por Pedro Gonçalves [1600], tanoeiro, morador em Vila do Conde, a Jorge Domingos, mercador, morador na freguesia de São Pedro de Avioso, termo do Porto, para que possa receber de Luís Mendes, mercador; morador no Porto, 20000 reais, de uma letra que sobre ele passou Manuel Fernandes Anjo, de Lisboa."

ADP Not $V$ Conde 1 cart $1 \mathrm{sr}$ lv $22 \mathrm{fl} 20 \mathrm{v}-21$ 
- Procuração de Antonia Francisca, viúva de Pedro Gonçalves, a Maria Dias, sua mãe, para receber de Luís Mendes, mercador da cidade do Porto, 35000 reais, o qual os recebera por letra por ele aceite. ADP Not V Conde 1 cart $1 \mathrm{sr} \operatorname{lv} 22 \mathrm{fl} 50-50 \mathrm{v}$

- Procuração [1590] passada por João Álvares da Costa, morador em Vila do Conde, a Gaspar Carneiro, morador em Vila do Conde, estante na cidade de Lisboa, para que possa receber de Tomás Ximenes, mercador e morador na cidade de Lisboa, cerca de 24000 reais, referente a uma letra passada na vila de Olinda, capitania de Pernambuco sobre o dito Tomás Ximenes, por João Moreno.

ADP NOT Vila do Conde 1ํㅜㄹorírio 1 sr lv 17 fls 90-91.

- Reconhecimento [1590], por Francisco de Brito, mercador, morador em Vila do Conde, de que Gonçalo Nunes, mercador, morador no Porto, lhe pagara 120400 reais referentes a uma letra que passara João Moreno, mercador, morador na vila de Olinda, capitania de Pernambuco. Esse dinheiro fora-lhe pago com base numa carta de aviso referente a esse pagamento, sem que as respectivas letras tivessem ainda chegado ao Reino, nem haver notícias dos navios em que foram enviadas. Assume o outorgante o compromisso de the devolver o referido dinheiro, como dinheiro de mercador a mercador, se as letras não chegassem dentro de um ano.

ADP NOT Vila do Conde 1ํㅡㄹ cartório 1 sr lv 15 fls 88-89.

- Procuração [1602] passada por Tomé Gonçalves, piloto, a António Afonso Sanches, irmão de Gaspar Afonso Sanches, este defunto, exmorador na cidade de Lisboa, a Miguel Luís Vilas Boas, mercador, moradores em Vila do Conde, e a Tomé Álvares, mareante, morador na Póvoa de Varzim. Esta procuração substitui uma outra, prévia, passada a Gaspar Afonso Sanches, entretanto falecido, para cobrar de Pero Vaz Galego, mercador, morador na cidade de Lisboa, uma quantia de 39000 reais, relativa a 4 caixas de açúcar vindas do Brasil que foram vendidas 
na llha de São Miguel, por seu mandado e por intermédio de Tomé Álvares, mareante, morador na Póvoa de Varzim , por Manuel João, mareante, morador em Vila do Conde.

ADP NOT Vila do Conde 1 cartório, 1 sr lv 11 fls $44 \mathrm{v}-46$.

- Procuração passada por Maria Carneira, mulher de Manuel da Fonseca, morador em Vila do Conde, ora estante e residente na vila de Olinda, a Baltasar Afonso Carneiro, pai dela, para cobrar, na cidade de Lisboa, a Pero Vaz Galego, mercador, o procedido da venda de 400 arrobas de açúcar que seu marido mandara do Brasil.

ADP NOT Vila do Conde, $1^{\circ}$ cartório, $1 \mathrm{sr}$ lv fls 52-53.

- Procuração [1597] de Brízida Rodrigues, mulher e procuradora de Manuel Fernandes, piloto, moradores na Rua da Misericórdia, a Nicolau Ferreira, mercador, para que pudesse cobrar, em Olinda, capitania de Pernambuco, um conjunto de letras de câmbio, no valor total de 195550 reais, e do que recebesse, extraídos os gastos, ficasse com uma comissão de $25 \%$, devendo empregar os restantes $75 \%$ em açúcar, a remetê-lo ao reino em nome de Manuel Fernandes ou sua mulher.

ADP Not V Conde 1 cart 1 sr lv $21 \mathrm{fl} 45-47 \mathrm{v}$

- Procuração passada por Manuel da Fonseca, mercador, a Belchior Luís, morador em Requião, termo de Barcelos, para que possa receber de Pedro Dias da Fonseca, morador na vila de Olinda, capitania de Pernambuco, o conteúdo de uma letra, que passara para ser paga na cidade de Lisboa e a não aceitaram, e que lhe fora recambiada através de Gaspar Fernandes, morador no termo de vila de Olinda, tendo sido entregue por João Álvares da Costa, piloto, morador em Vila do Conde.

- Procuração de António Dias Pachão [1606], piloto, a Pedro Gonçalves, barbeiro, para que vá a Lisboa, receber de Henrique Dias Milão, aí morador, em Alcântara, 100000 reais, valor de que tinha passada letra a pagar por Francisco Nunes Ximenes, morador no Porto, que não a aceitou, tendo-a recambiado. 
- Procuração passada por João Álvares da Costa, morador em Vila do Conde, a Gaspar Carneiro, morador em Vila do Conde, estante na cidade de Lisboa, para que possa receber de Tomás Ximenes, mercador e morador na cidade de Lisboa, cerca de 24000 reais referentes a uma letra passada na vila de Olinda, capitania de Pernambuco, sobre o dito Tomás Ximenes, por João Moreno.

ADP Not V Conde 1 cart $1 \mathrm{sr}$ Iv $17 \mathrm{fls}$ 90-91.

- Contrato feito entre Paulo Nunes Vitória, mercador, e Francisco Freire, piloto, em torno de uma armação comercial envolvendo têxteis do Norte da Europa, açúcar e escravos, em que era principal investidor Diogo Pereira, mercador, morador no Porto.

ADP Not V Conde 1 cart 3 sr Iv 12 fl 85-88v

- Reconhecimento de que o navio no qual Francisco de Cáceres era o maior comissionado que ia do Porto para a Bahia, afundou numa tormenta, envolvendo a carga numa disputa judicial.

ADP, NOT, PO1, I.136, fls. 4v.-5v. (1615-6-27)

- Escritura de contrato [1621] entre Pedro Gonçalves, mercador, e Pedro Fernandes, mareante e mestre da nau Nossa Senhora do Rosário, sobrinho do anterior, pela qual o segundo reconhecia que o primeiro tinha investido na construção e na armação da dita nau 1000000 reais, para serem aplicados na compra de escravos em Angola e o rendimento da venda destes no Brasil na compra de açúcar. ADP Not $V$ Conde 1 cart $1 \mathrm{sr}$ Iv $32 \mathrm{fl}$ 132v-135 


\section{Arquivo Nacional da Torre do Tombo}

Carta do ouvidor de Campo de Ourique sobre o serviço de que o rei esperava Ihe fizessem os concelhos da dita Câmara para a restauração do Brasil e na mesma se nomeiam os concelhos, terras e o quanto davam, e o que rendia o cabeção de cada uma.

1631-12-26 Corpo Cronológico, Parte I, mç. 118, no 125

Alvará para se pagar a Francisco de Cáceres 40.000 réis de tença Corpo Cronológico, Parte I, mç. 42, n.ำ 132

Carta do marquês de Maensa para Pedro de Salazar e Filipe de Aranha para dar em conta do que se tinha feito nos papéis pertencentes a António Fernandes de Elvas. 1629-10-11 Corpo Cronológico, Parte I, mç. 117, oo 176

Cópia da carta dirigida ao marquês de Maensa sobre a execução feita aos herdeiros de António Fernandes de Elvas, pela quantia de 220.000 maravedis, de alcance e pena de não terem dado contas da receita dos escravos negros que se levaram às Índias. 20.09.1629

Corpo Cronológico, Parte I, mç. 117, no 177

Corpo Cronológico, Parte 1르, Maço 105, n. 75

Corpo Cronológico, Parte 1르, Maço 106, n.․․ 23, 26

Corpo Cronológico, Parte 1a, Maço 108, n.ำ 15, 35, 55, 78, 108.

Corpo Cronológico, Parte 1르, Maço 114, n.ำ 32.

\section{Arquivo Histórico Ultramarino:}

- CARTA RÉGIA (capítulo) do rei [D. Filipe II] ao Conselho da Fazenda, ordenando as normas para a comercialização das fazendas e açúcar na costa do Brasil na tentativa de se evitar contrabando.

AHU_ACL_CU_015, Cx.1, D. 27. 
- Requerimento do [contratador dos Dízimos do Açúcar da capitania de Pernambuco, Itamaracá, Paraíba e Rio Grande], Gaspar Ximenes, ao rei [D. Filipe II], pedindo traslado, por certidão, do auto de arrematação dos dízimos, do Regimento do provedor e contador da Fazenda Real e de um alvará para um Requerimento que tem no Conselho da Fazenda.

AHU_ACL_CU_015, Cx 1, D. 66.

\section{Fontes manuscritas}

Processos Inquisitoriais

\section{Inquisição de Lisboa}

Ana de Milão, processo no 279

Antonio Dias, processo o 8478 .

Brites Fernandes, processo ํㅜ 4580.

Diogo de Matos Pinel oㅜ 7136.

Duarte Nunes da Costa, processo no 7192.

Francisco de Cáceres, processo no 3068

Fernão Lopes Milão, processo ํo 2523

Francisco de Orta, processo ํo 10312.

Francisco Palácios, processo no 4481-1

Gabriel Ribeiro, processo, ㄲo 8056.

Gaspar Fernandes Penso, processo17562.

Gaspar Lopes Homem, processo ํo 8543.

Gabriel Mendes (Abraão Mendes), processo oㅜ 11362.

Gomes Rodrigues de Milão oㅜ 2499.

Guiomar Gomes, processo ํo 6671 .

Heitor Mendes Bravo, processo № 12493.

Henrique Dias Milão, processo ํo 6677 .

Henrique Solis, processo № 10536.

João Nunes Correia, processo nำ12464.

Manuel Nunes de Matos, processo ํo 10600.

Manoel Homem de Carvalho, processo oㅜ 3157. 
Mateus Lopes Sampaio, processo no 4303.

Miguel Francês (David Francês), processo oㅜ 7276.

Paulo de Milão, processo №. 3338

Pedro de Almeida, processo oㅜ 11562.

Pedro Francês, processo no 11448.

Pero de Baeça, processo, ㄲo 11559.

Rui Gomes, processo nํ.1971.

Vicente Furtado, processo ํㅡ 3333

\section{Inquisição de Coimbra}

Antonio Rodrigues, processo ํo 9377

Isabel Henriques, Processo oㅜ 9287.

\section{Fontes impressas}

Alvarás de 1551, 1555 e 1574 sobre isenção e arrecadação dos tributos do açúcar. INSTITUTO DO AÇÚCAR E DO ÁLCOOL. Documentos para a História do Açúcar. Vol. I. Legislação (1534-1596). Rio de Janeiro: Instituto do Açúcar e do Álcool, 1954.

Alvará de 25 de Janeiro de 1583 sobre a arrecadação dos tributos do açúcar. In:INSTITUTO DO AÇÚCAR E DO ÁLCOOL. Op. cit., p. 315.

ABECASSIS, José Maria. Genealogia Hebraica: Portugal, e Gibraltar, séc. XVII-XX.Lisboa: José Maria Abecassis, 1990-1991.5 v.

ANAIS DA BIBLIOTECA NACIONAL DO RIO DE JANEIRO. Livro das Denunciações que se fizeram na Visitação do Santo Officio à Cidade do Salvador da Bahia de Todos os Santos do Estado do Brasil, no ano de 1618 Inquisidor e Visitador, o Licenciado Marcos Teixeira. 1927, volume XLIX. Rio de Janeiro: Biblioteca Nacional, 1936. 
ANAIS DO MUSEU PAULISTA. Segunda Visitação do Santo Ofício às partes do Brasil pelo inquisidor e visitador o licenciado Marcos Teixeira. Livro das Confissões e Ratificações da Bahia - 1618-1620. Tomo XVII. Introdução de Eduardo d'Oliveira França e Sônia Siqueira. São Paulo, 1963.

ANAIS DO MUSEU PAULISTA. Devassa do Bispo D. Pedro da Silva (16351637). Tomo XXII. Universidade de São Paulo, 1968.

ANTONIL, André João. Cultura e opulência do Brasil por suas drogas e minas. Belo Horizonte: Itatiaia; São Paulo: Edusp. 1982.

BRANDÃo, Ambrósio Fernandes. Diálogos das Grandezas do Brasil. Recife: Massangana, 1997.

ABREU, J. Capistrano de. Capítulos de História Colonial (1500-1800). Rio de Janeiro: Livraria Briguiet, 1954.

CARDIM, Fernão. Tratados da Terra e da Gente do Brasil. Rio de Janeiro: J. Leite e Cia, 1925. FONSECA, Vitoriano Borges da. Nobiliarchia Pernambucana. Rio de Janeiro: BibliotecaNacional, 1925.2 v.

Fontes Para a História do Brasil Holandês: A Economia Açucareira. Documentos traduzidos e organizados por José Antônio Gonsalves de Mello. v. 1, Recife: CEPE/Parque Histórico Nacional dos Guararapes, 198

Fontes Para a História do Brasil Holandês: A Economia Açucareira. Documentos traduzidos e organizados por José Antônio Gonsalves de Mello. v. 1, Recife: CEPE/ParqueHistórico Nacional dos Guararapes, 1981.

Livro Primeiro do Governo do Brasil, 1607-1633. Estudos Históricos, Rio de Janeiro, 1958.

FREI VICENTE do SALVADOR. História do Brasil (1500-1627). São Paulo: Melhoramentos/INL. 1975. 
GANDAVO, Pero de Magalhães. Tratado da Terra do Brasil: História da Província de Santa Cruz. Belo Horizonte: Itatiaia; São Paulo: Edusp, 1980.

INDEX das Notas de Varios Tabelliães de Lisboa, entre os Annos de 1580 e 1747, 4 vols, Lisboa, s.n., 1930

MELLO, José Antônio Gonsalves de. Os Livros das Saídas das Urcas do Porto do Recife,

1595 -1605. In: Revista do Instituto Arqueológico Histórico e Geográfico de

Pernambuco. Recife, 1993.

MORENO, Diogo Campos. Livro que dá Razão do Estado do Brasil. Rio de Janeiro: Instituto Nacional do Livro / Ministério de Educação e Cultura, 1968.

Notorial Records in Amsterdam relating to the portuguese jews. In:

Studia Rosenthaliana: Jornal for Jewish Literature and History in the Netherlands, University Library of Amesterdam Vol. I ao XV, 1967 (coleção acervo Instituto Ricardo Brennand).

Ordenações Manuelinas. Livro II, Título 41. Ordenações Manuelinas / ed. lit. Fundação Calouste Gulbenkian. Apresentação Mário Júlio de Almeida Costa. Ed. fac. sim. Lisboa, 1984.

Ordenações e Leis do Reino de Portugal Recompiladas por Mandado Del rei D. Filipe, o Primeiro. 12.ed. Segundo a $9^{\mathrm{a}}$ de Coimbra de 1824, Coimbra: Imprensa da Universidade,1850. $3 \mathrm{v}$.

Primeira Visitação do Santo Officio às partes do Brasil pelo licenciador Heitor Furtado de Mendonça capellão fidalgo del Rey nosso senhor e do seu desembargo, deputado do Santo Officio. Denunciações da Bahia 1591-1593. 3 volumes. São Paulo: Paulo Prado, 1922-1929. 
Primeira Visitação do Santo Officio às partes do Brasil pelo licenciado Heitor Furtado de Mendonça - Denunciações de Pernambuco. 1593/1595. São Paulo: Paulo Prado, 1929.

Primeira Visitação do Santo Officio às partes do Brasil pelo licenciador Heitor Furtado de Mendonça - Confissões da Bahia. 1591/1592. Rio de Janeiro: F. Briguet e Cia Ed., 1935.

Primeira Visitação do Santo Officio às partes do Brasil pelo licenciador Heitor Furtado de Mendonça - Confissões de Pernambuco, 1594/1595. Recife: Ed. Universidade Federal de Pernambuco, 1970.

Santo Ofício da Inquisição de Lisboa: Confissões da Bahia (org. Ronaldo Vainfas). São Paulo: Companhia das Letras, 1997. Série Retratos do Brasil.

Segunda Visitação do Santo Ofício às partes do Brasil pelo Inquisidor e Visitador o licenciado Marcos Teixeira. Livro das Confissões e Ratificações da Bahia-1618-1620. São Paulo: Anais do Museu Paulista, tomo XVII, 1963.

\section{Bibliografia}

ALENCASTRO, Luis Felipe. O Trato dos Viventes: Formação do Brasil no Atlântico Sul. Século XVI e XVII. São Paulo: Companhia das Letras, 2000.

ALMEIDA, A. A. Marques de. Capitais e capitalistas no comércio da especiaria: o eixo Lisboa-Antuérpia (1501-1549). Lisboa: Cosmos, 1993.

. Comunidades judaicas na época moderna em Trás-os-Montes: uma revisitação da historiografia. Cadernos Terras Quentes. Aveiros (Portugal), n. 1, 2005. 
. Mercadores cristãos-novos no negócio da especiaria (entre 1480 e 1530). Lisboa: Cátedra de Estudos Sefarditas Alberto Benveniste, s/d.

- O zangão e o mel: uma metáfora sobre a diáspora sefardita e a formação das elites financeiras na Europa (séculos XV a XVII). Oceanos, Lisboa, n. 29, jan./mar. 1997.

ANTUNES, Cátia. Globalization in the early modern period: the economic relationship between Amsterdam and Lisbon, 1640-1705. Aksant: Amsterdam, 2004.

ARKIN, Marcus. Aspects of Jewish Economic History. Philadelphia: The Jewish Publication Society of America, 1975.

ASSIS, Ângelo Adriano Faria de. O Rabi Escatológico e o Rabi Macabeu: diferenças e aproximações na prática do rabinato judaico no Brasil Quinhentista a partir do olhar do Santo Ofício. Espírito Santo: Anpuh, 2002.

ATTALI, Jacques. Os Judeus, o Dinheiro e o Mundo. São Paulo: Futura, 2003.

AZEVEDO, João Lúcio de. História dos cristãos-novos portugueses. Lisboa: Clássica Editora, 1989.

BAERS, João. Olinda Conquistada - Narrativa do Padre João Baers. Traduzido do holandês por Alfredo de Carvalho, do Instituto Arqueológico e Geographico Pernambucano. Recife: Tyipographia de Laemmert \& C.-Editores, 1898.

BARROS, Amândio Jorge Morais, O negócio atlântico: as redes comerciais portuenses e as novas geografias do trato internacional (séculos XVI-XVII). Revista da Faculdade de Letras. História. Porto, III Série, vol. 8, 2007, pp. 2947. 
. Vinhos de Escala e Negócios das Ilhas: para uma longa história das relações do Porto com os arquipélagos atlânticos no século XVI, Porto, 2004.

. Porto: A construção de um espaço marítimo no alvorecer dos tempos modernos. Tese (Doutorado em História Moderna) - Faculdade de Letras, Universidade do Porto, 2004.

BARROS, Edval de Souza. Redes de clientela, funcionários régios e apropriação de renda no império português (séculos XVI-XVIII). Revista Sociologia e Política, São Paulo, nov. 2001, №.17.

BASTO, Artur C. Barros de, Os Judeus no Velho Porto, Separata da Revista de Estudos Hebraicos, Vol. I-II, 1929.

BEAUD, Michel. História do capitalismo. São Paulo: Brasiliense, 1987.

BETHENCOURT, Francisco. História das Inquisições. Portugal, Espanha e Itália. Séculos XV-XIX. São Paulo: Companhia das Letras, 2000.

BICALHO, Maria Fernanda; FERLINE, Vera Lúcia Amaral (org.). Modos de Governar: ideias e práticas no Império português, Séculos XVI-XIX. São Paulo: Alameda, 2005.

BODIAN, Miriam, Hebrews of the Portuguese Nation: Conversos and Community in Early Modern Amsterdam, Bloomington, 1999.

BOYAJIAN, James C. New Christians and Jews in the Sugar Trade 1550 1750: Two Centuries of Development of the Atlantic Economy, USA: The John Carter Brown Library, 2001. 
. Portuguese traders in Asia under the Habsburgs 1580-1640.

Baltimore: Johns Hopkins University Press, 1993.

. Portuguese Bankers at the Court of Spain, 1626-1650, New

Brunswick, 1983.

. The New Christian Reconsidered: Evidence from Lisbon's

Portuguese Bankers, 1497-1647. In: Studia Rosenthaliana, vol. 15, n. 1 (1981).

BOXER, Charles Ralph. O império marítimo português: 1415-1825. São Paulo:

Companhia das Letras, 2002.

BRAUDEL, Fernand. Civilização material, economia e capitalismo: séculos XVXVIII. São Paulo: Martins Fontes, 2009.

BRITH, Joseph Ben Brith. Dye Odissee der Henrique Familie. Frankfurt au Main: Peter Lang, 2001.

BURKE, Peter. Veneza e Amsterdã: um estudo das elites do século XVII. São Paulo: Brasiliense, 1991.

CAVALCANTI, Irenilda. Rede social e estratégias de ascensão: cartas de Martinho de Mendonça para a corte de D. João V. In: MONTEIRO, Rodrigo Bentes (Org). Espelhos Deformantes: fontes, problemas e pesquisas em História Moderna (séculos XVI-XIX). São Paulo: Alameda, 2008.

COELHO, António Borges, Inquisição de Évora (1533-1668), Lisboa, Plátano, 2002. 
. Política, dinheiro e fé: Cristãos-novos e judeus no tempo dos Filipes. In: Cadernos de Estudos Sefarditas Alberto Benveniste. oㅜ 1 (Ciclo de Conferências 2000. Lisboa: Faculdades de Letras de Lisboa. 2001).

COSTA, Maria Leonor Freire da. O transporte no Atlântico e a Companhia geral do Comércio do Brasil (1580-1663). Vol. I. Lisboa: Comissão Nacional para as Comemorações dos Descobrimentos Portugueses, 2002.

. Império e Grupos Mercantis. Entre o Oriente e o Atlântico (século XVII), Lisboa, Livros Horizonte, 2002. vols. I-II

A Rota do cabo e as rotas do Brasil: para um estudo comparado do transporte marítimo nos séculos XVI e XVII. Texto apresentado no Seminário: O mundo que o Português criou. Pernambuco, 2000.

DYSNeY, A. R. A Decadência do Império da Pimenta: Comércio Português na Índia no início do século XVII. Lisboa: Edições 70, 1981.

EBERT, Christopher. Between Empires: Brazilian sugar in the early Atlantic economy 1550- 1630. Leiden; Boston: Brill, 2008.

EMMER, Peter C., The First Global War: The Dutch versus Iberia in Asia, Africa and the New World, 1590-1609. In: e-Journal of Portuguese History, vol. 1, n. 1 (Summer 2003).

. The Dutch and the making of the second atlantic system. In: Barbara L.Solow (Org.). Slavery and the Rise of the Atlantic System. New York: 1991. . O comércio holandês do sal e do açúcar, 1585-1650. Anais do I Seminário Internacional sobre o Sal Português. Porto, Aveiro, 27-29 maio 2004. 
FABEL, Nachman (Org); MILGRAM, Avraham.; DINES, Alberto. Em Nome da Fé. Estudos in Memoriam de Elias Lipiner. São Paulo: Perspectiva, 1999.

FERLINI, Vera Lucia Amaral. Terra, Trabalho e Poder: O mundo dos engenhos no Nordeste colonial. Bauru: EDUSC, 2005.

Açúcar e Colonização (da América portuguesa ao Brasil: ensaios de interpretação). Tese de Livre-Docência. São Paulo: FFLCH/História/USP, 2000.

FERNANDES, Florestan. Circuito Fechado. São Paulo: Hucitec. 1976.

FERNANDES, Vieira Manuel Antonio In: Os Mercadores Banqueiros de Viana no Século XVII. Cadernos Viananses, 21, 1996.

FRADE, Florbela Veiga. As relações econômicas e sociais das comunidades sefarditas portuguesas. O trato e a família, 1532-1632. Lisboa, 2006. [Tese de Doutoramento] Faculdade de Letras da Universidade de Lisboa.

. A emigração dos judeus portugueses. Fugas ou saídas? Cadernos de Estudos Sefarditas, № 2. Cátedra Alberto Benveniste. Lisboa, 2002.

FRAGOSO João. A nobreza da República: notas sobre a formação da primeira elite senhorial do Rio de Janeiro (séculos XVI e XVII). Rio de Janeiro. IFCS, 2000 №1.

; BICALHO, Maria F. B; GOUVÊA; Maria de Fátima (org.). O Antigo Regime nos trópicos: a dinâmica imperial portuguesa (séculos XVI-XVIII). Rio de Janeiro: Civilização Brasileira, 2001. 
; GOUVÊA, Maria de Fátima (org.). Na Trama das Redes: Política e Negócios no Império português, séculos XVI-XVIIII. Rio de Janeiro: Civilização Brasileira, 2010.

FRANÇA, Eduardo; SIQUEIRA, Sonia. Introdução, In: Segunda Visitação do Santo Ofício às Partes do Brasil pelo Inquisidor e Visitador Marcos Teixeira, Livro das Confissões e Ratificações da Bahia: 1618-1620, São Paulo, 1966.

FREYRE, Gilberto. Casa Grande e Senzala. São Paulo: Global, 2004.

FURTADO, Celso. Formação Econômica do Brasil. São Paulo: Editora Nacional, 1991.

FURTADO, Júnia Ferreira (org.). Diálogos Oceânicos: Minas Gerais e as novas abordagens para uma história do Império Ultramarino Português. Belo Horizonte: Editora UFMG, 2001.

GODINHO, Vitorino Magalhães. História econômica e social da expansão portuguesa. Lisboa: Terra, 1957.

- Mito e mercadoria, utopia e prática de navegar, séculos XIII-XVIII. Lisboa: Difel, 1990.

. Os descobrimentos e a economia mundial, v, II, III e IV. Lisboa: Editorial Presença, 1987.

GONSALVES DE MELLO, José Antonio. Gente da nação: cristãos-novos e judeus em Pernambuco, 1542-1654. Recife: Massangana, 1966.

. Os magnatas do tráfico negreiro. São Paulo: Pioneira, 1981. 
. Os Cristãos-novos e o Comércio no Atlântico Meridional. São Paulo:

Pioneira; Brasília: INL, 1978.

. O Recife: importância do período nórdico-tropical de sua formação.

In: Seminário de Tropicologia: trópico \& o Recife eurotropical, 1977, Recife. Anais... Organização e prefácio de Roberto Motta. Recife: Fundaj, Massangana, 1987.

GREIF, Avner. Contract Enforceability and Economic Institutions in Early Trade: the Maghribi Traders Coalition. The American Economic Review, 1983.

GRINBERG, Keila (org.). Os Judeus no Brasil: Inquisição, Imigração e Identidade. Rio de Janeiro: Civilização Brasileira, 2005.

GUINOTE, Paulo J. A. Ascensão e Declínio da Carreira da Índia. (Séculos XVXVIII). Lisboa: Fundação Calouste Gulbenkian, vol. II, 1999.

HUTZ, Ana. Os cristãos-novos portugueses no tráfico de escravos para América espanhola (1580-1640). Dissertação (Mestrado em Economia) Instituto de Economia, Universidade Estadual de Campinas, São Paulo, 2008.

- Redes comerciais cristãs novas no Brasil durante o reinado de

Filipe III. Disponível

em:<ttp://cihe.fflch.usp.br/sites/cihe.fflch.usp.br/files/Ana_Hutz.pdf>

ISRAEL, Jonathan Irvine. Empires and Entrepots: The Dutch, The Spanish Monarchy and The Jews, 1585-1713. Londres: The Hembledon Press, 1990.

Dutch Primacy in World Trade 1585-1740. London: Oxford, 1989. 
- The Economic Contribution of the Dutch Sephardic Jewry to Holland's Golden Age, 1595-1713 In: J.I. Israel, Empires and Entrepots - The Dutch, the Spanish Monarchy and the Jews, 1585-1713. Londres, 1990. . Diasporas wthin a Diaspora: Jews, CRypto-Jews, and the World of Maritime Empires 1540-1740. Leiden: Brill, 2001.

IZECKSOHN, Isaac. Os Marranos Brasileiros. Rio de Janeiro: José Olímpio, 1967.

KAPLAN, Yosef (Ed.). Jews and Conversos. Studies in Society and the Inquisition. Proceedings of the Eighth World Congress of Jewish Studies held at The Hebrew University of Jerusalem, August, 16-21, 1981.

KAYSERLING, Meyer. História dos Judeus em Portugal. São Paulo: Pioneira, 1971.

KELLEBENZ, Hermann. Los Fugger en España y Portugal hasta 1560. Bertrand: Junta Castilla-Leon, 2000.

- Relações Econômicas entre Antuérpia e o Brasil no século XVII, Revista de História. Vol. XXXVIII № 76. 1968.

HERMANN, Kollbenz. Relações Econômicas entre Antuérpia e o Brasil no século XVII. Revista de História. v. XXXVII, n. 76, São Paulo, 1968.

LIPINER, Elias. Os judaizantes nas capitanias de cima (estudos sobre os cristãos-novos do Brasil nos séculos XVI e XVIII). São Paulo: Brasiliense, 1969.

MAURO, Frédéric. O Brasil, Portugal e o Atlântico 1570-1670, 2 vols. Lisboa, Platano 1988. 
. Nova História e Novo Mundo. São Paulo: Perspectiva, 1973.

. Expansão Europeia. São Paulo: Pioneira, 1980.

- Marchands et Marchands-Banquiers Portugais au XVIII Siècle.

Coimbra, 1961.

MATEUS, Suzana. Família e Poder: a importância dos laços de parentesco na construção das redes mercantis sefarditas (séculos XVI e XVII). In: Cadernos de Estudos Serfaditas Lisboa: Cátedra de Estudos Sefarditas Alberto Benveniste, 2000.

MEA, Elvira Cunha de Azevedo, A Inquisição de Coimbra no Século XVI: A Instituição, os Homens e a Sociedade. Porto, 1997.

MELLO, Evaldo Cabral de. O negócio do Brasil: Portugal, os Países Baixos e o Nordeste 1641-1669. Rio de Janeiro: Topbooks, 1998.

. Uma questão de nuança. Brasil 500. 23 jan. 2000. http://www1.folha.uol.com.br/fol/brasil500/ acesso em 18 de nov. 2004.

. O Bagaço da Cana: os engenhos de açúcar do Brasil holandês.

São Paulo: Peguin: Companhia das Letras, 2012.

MELLO, José Antonio Gonsalves de. Gente da Nação. Cristãos-novos e judeus em Pernambuco 1542-1654. Recife: Fundação Joaquim Nabuco, Editora Massangana, 1989.

. "Os Livros das Saídas das Urcas do Porto do Recife, 1595-1605".

Revista do Instituto Arqueológico, Histórico e Geográfico Pernambucano. Recife, 1993. 
. O Recife: importância do período nórdico-tropical de sua formação.

Seminário de Tropicologia: trópico \& o Recife eurotropical. Anais..., 1977. Recife. Fundaj; Massangana, 1987.

NOVAIS, Fernando Antonio. Aproximações: ensaios de história e historiografia. São Paulo: Cosac Naif, 2005.

. (dir.) A História da Vida privada No Brasil. São Paulo: Companhia das Letras, 1997.

. Portugal e Brasil na Crise do Antigo Sistema Colonial. São Paulo: Hucitec, 2001.

NOVINSKY, Anita. Cristãos-novos na Bahia: 1624:1654. São Paulo: Edusp, 1972.

- Inquisição: prisioneiros do Brasil. Séculos XVI-XIX. Rio de Janeiro:

Expressão e Cultura, 2002.

PORTO, Costa. Os cinco primeiros engenhos pernambucanos. In: Revista do Museu do Açúcar. № 2, Recife, 1969. Apud: Ana Hutz. Redes comerciais cristãs novas no Brasil durante o reinado de Filipe III. Disponível em: $<$ http://cihe.fflch.usp.br/sites/cihe.fflch.usp.br/files/Ana_Hutz.pdf>.

PRADO JUNIOR, Caio. Formação do Brasil Contemporâneo. São Paulo: Brasiliense, 2008. . História Econômica do Brasil. São Paulo: Brasiliense, 1977.

ROITMAN, Jessica Vance. The Same but the Different? Inter-cultural Trade and the Sephardim, 1595-1640. Leiden: Brill, 2011. 
RAU, Virgínia. Os manuscritos do Arquivo da Casa de Candaval Repositantes ao Brasil. Vol I. Coimbra: 1954.

. Senhores de engenho judeus em Pernambuco Colonial (15421654). Recife: 20-20 Comunicação e Editora, 1998.

RICARDO, Silvia. As redes mercantis no final do século XVI e a figura do mercador João Nunes Correia. Dissertação (Mestrado em História Econômica) - Faculdade de Filosofia, Letras e Ciências Humanas, Universidade de São Paulo, São Paulo, 2007.

RICUPERO, Rodrigo. A formação da elite colonial: Brasil c.1530-c.1630. São Paulo: Alameda, 2009.

ROTH, Cecil. A History of the Jews in England, Oxford, 1964.

SALLES LOUREIRO, Fernando. A alteração das coordenadas da política de expansão portuguesa na segunda metade do século XVI, in: Actas das Primeiras Jornadas de História Moderna, vol. I, Lisboa, Centro de História da Universidade de Lisboa, 1986.

SALOMON, Herman Prins. Apresentação. In: ROTH, Cecil. História dos Marranos. Porto: Livraria Civilização Editora, 2001.

. Herman Prins. Portrait of a New Christian Fernão Alves Melo (15691632), Paris: Fundação Calouste Gulbenkian/Centro Cultural Português. 1982. . "The 'De Pinto' Manuscript - a 17th Century Marrano Family History." In a special issue of the Studia Rosenthaliana, vol. 9, n. 1, 1975. 
SALVADOR, José Gonçalves. Os cristãos-novos: povoamento e conquista do solo brasileiro 1530-1680. São Paulo: Pioneira/ Universidade de São Paulo, 1976.

. Os cristãos-novos e o comércio no Atlântico Meridional (com enfoque nas Capitanias do Sul 1530-1668). São Paulo: Pioneira, 1978.

. Cristãos-novos, Jesuítas e Inquisição. São Paulo: Livraria Pioneira/ USP, 1969.

. Os magnatas do tráfico negreiro. São Paulo: Pioneira; Edusp, 1981

. Vozes da História. São Paulo: Humanitas, 2001.

SANDRONI, Paulo. Novo Dicionário de Economia. São Paulo: Círculo do Livro, 1994.

SARAIVA, Antonio José. Inquisição e cristãos-novos. Lisboa: Estampa. 1985. . The Marrano Factory: The Portuguese Inquisition and Its new Christians, translated, revised and augmented by Herman Prins Salomon and Isaac S.D. Sassoon: Leiden, 2001.

SCHAMA, Simon. O desconforto da riqueza. São Paulo: Companhia das Letras, 1992.

SCHWARTZ, Stuart B., LOCKHART, James. A América Latina na época colonial. Rio de Janeiro: Civilização Brasileira, 2002.

. Segredos internos: engenhos e escravos na sociedade colonial 1550-1835. São Paulo: Companhia das Letras, 1999. 
. A Commnwealth within itself: the early Brazilian sugar industry, 1550-1670. Revista de Índias, 2005, vol. LXV, no 23. p. 79-116.

- Prata, açúcar e escravos: de como o império restaurou Portugal.

Tempo [online]. 2008, vol.12, n. 24, p. 201-223. <http://dx.doi.org/10.1590/S1413-77042008000100011.>

. Tropical Babylons: Sugar and the Making of the Atlantic World, 1450-1680. Chapel Hill: University of North Carolina Press, 2004.

SERRÃO, Joel e OLIVEIRA MARQUES, A. H. (dir.). Nova História Portuguesa: O Império Luso-Brasileiro (1500-1620). Lisboa: Editorial Estampa, 1992.

SERRÃO, Joel. Dicionário da História de Portugal, 6 vls., Porto, Livraria Figueirinhas.

SILVA, José Gentil da. Merchandises et Finances: Lettres de Lisbonne (15631578). Paris : Sevpen, 1961.

. O Eixo Econômico Lisboa-Antuérpia. Anais da exposição Portugal e Flandres, visões da Europa (1550-1680). Lisboa: Instituto Português do Patrimônio Cultural Mosteiro dos Jerónimos, abr.-maio 1992.

. Strategie des Affaires a Lisbonne entre 1595-1607. Paris: Librairie Armand Colin, 1956.

SILVA, Janaina Guimarães da Fonseca. Comerciantes Cristãos-Novos: do açúcar ao tráfico de escravos para as Índias de Castela. Disponível em:<www.historia.uff.br/7mares/wp-content/uploads/2014/04/v01n01a11.pdf.> Acesso em: 12 jul. 2014. 
- Cristãos-novos nos negócios da capitania de Pernambuco: relacionamentos, continuidades e rupturas nas redes de comércio entre os anos de 1580 e 1630. [Tese de Doutorado]. UFPE, 2012.

SILVA, Marco Antônio Nunes da. O Brasil Holandês nos Cadernos do Promotor: Inquisição de Lisboa, século XVII. [Tese de Doutorado]. FFFLCH, USP, 2003.

SIQUEIRA, Sonia A. A Inquisição portuguesa e a sociedade colonial. São Paulo, Ática, 1978.

. O Comerciante João Nunes. In: Anais do V Simpósio Nacional dos Professores Universitários de História, vol 1. São Paulo: 1971.

A Expulsão dos Judeus de Portugal: a conjuntura peninsular, in Oceanos. Diáspora e Expansão, Lisboa, № 29, Jan./Mar.1997. - Inquisição e CristãoS-Novos de Trás-os-Montes. Primeira Jornada de História Moderna, vol. 1, (Lisboa), Centro de História da Universidade de Lisboa, [s.d].

. Judeus, cristãos-novos e os descobrimentos portugueses, Safarad, ano 48, fasc. 1, Madrid, 1988.

. Judaísmo e inquisição. Estudos, Lisboa, Editorial Presença, 1987.

- A inquisição portuguesa e a sociedade colonial - Ação do Santo

Ofício na Bahia e Pernambuco na Época das Visitações. Tese de Livre Docência, Universidade de São Paulo, 1994. 
. A inquisição portuguesa e a sociedade colonial, Ensaios, vol. 56, São Paulo, 1978.

SLUITER, Engel. "Os holandeses no Brasil antes de 1621." In: Revista do Instituto Arqueológico, Histórico e Geográfico Pernambucano, v. 46.Recife, 1967.

SMITH, David Grant. The Mercantile Class of Portugal and Brazil in the Seventeenth Century: A Socio-Economic Study of the Merchants of Lisbon and Bahia. 1620-1690, Ann Arbor, Xerox University Microfilms, 1975.

STOLS, Eddy. A iconografia do Brasil nos Países-Baixos do século XVI ao XX: uma tentativa de avaliação global. Revista USP. São Paulo, n. 30.

Os mercadores flamengos em Portugal e no Brasil antes das conquistas holandesas. In: Separata dos Anais de História, vol. 5 (Assis, 1973).

STRUM, Daniel. Entre os embargos e a inquisição: cristãos-novos e "framenguos" na rota do açúcar. Anais do XXVI simpósio Nacional de HistóriaANPUH. São Paulo, julho, 2011.

. The Portuguese Jews and New Christians in the Sugar Trade: Managing Business Overseas - Kinship and Ethnicity Revisited (Amsterdam, Porto and Brazil, 1595-1618),[Ph.D. dissertation]. Hebrew University of Jerusalem, 2009.

STUDNICKI-GIZBERT, Daviken. A Nation upon the Ocean Sea: Portugal's Atlantic Diaspora and the Crisis of the Spanish Empire, 1492-1640. London: Oxford University Press, 2002. 
SWETSCHINSKI, Daniel M., Kinship and Commerce. The Foundations of Portuguese Jewish Life in $17^{\text {th }}$ Century Holland. In: Studia Rosenthaliana, vol. 13, no. 2 (1979).

. Reluctant cosmopolitans: the Portuguese Jews of SeventeenthCentury Amsterdam. London; Portland, Oregon: Littman Library of Jewish Civilization, 2000. . The Portuguese Jewish Merchants of Seventeenth Century

Amsterdam: A Social Profile. Ph. D. [diss.] Brandeis University, 1979.

TAVARES, Maria José Pimenta Ferro. Judaísmo e Inquisição. Lisboa: Estampa, 1987. . Judeus, cristãos-novos e os descobrimentos, s.I., Elo.1995.

. Os Judeus em Portugal no século XV. Lisboa: Universidade Nova de Lisboa, 1982.

. Os Judeus Portugueses na Diáspora. João Medina (dir.) História de Portugal. V.VI. Lisboa: 1998.

TORO, Alfonso. La familia Carvajal: Estudio histórico sobre los Judios y la Inquisición de la Nueva España en el siglo XVI. Cidade do México: Patria, 1944

VAINFAS, Ronaldo. Jerusalém colonial: judeus portugueses no Brasil holandês. Rio de Janeiro: Civilização Brasileira, 2010. 
VENTURA, Maria da Graça A. Mateus. Cristãos-novos portugueses nas Indias de Castela: dos negócios aos cárceres da Inquisição (1590-1639). In: Oceanos. Diáspora e Expansão, Lisboa, № 29, jan./mar.1997.

. Os Gramaxo. Um caso paradigmático de redes de influência em Cartagena das Indias. Revista Atlântica de Cultura Ibero-Americana. oㅡ 2. Lisboa, Primavera-Verão de 2003.

WALLERSTEIN, Immanuel. O Sistema Mundial Moderno, 2 vols., Porto, Ed. Afrontamento, 1990.

Weber, Max. A Ética Protestante e os Espíritos do Capitalismo, $5^{\text {a }}$ ed., Lisboa, Presença. 2001

WIZNITZER, Arnold. Os Judeus no Brasil Colonial. São Paulo: Pioneira, EDUSP, 1966.

WOLFF, Egon e Frieda. A odisséia dos judeus de Recife. São Paulo: Centro de Estudos Judaicos, 1979.

Judeus em Amsterdã. Rio de Janeiro: Instituto Histórico e Geográfico, 1989.

. Os Judeus Portugueses de Amsterdã e o Brasil. In: Revista do Instituto Histórico e Geográfico Brasileiro, a. 147, n. 351. abr./jun. 1986. Rio de Janeiro. 